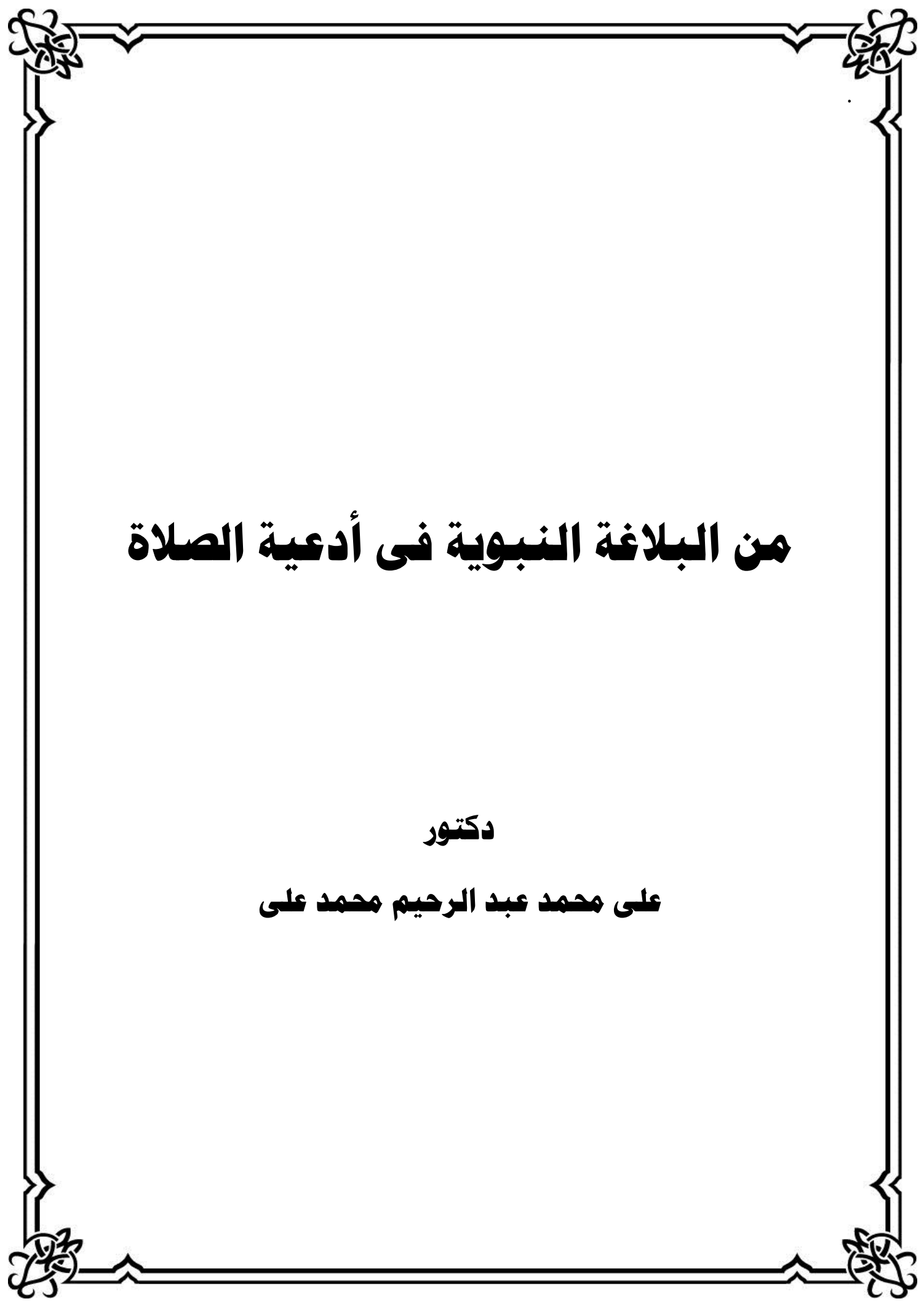




\section{مقدمة مقة}

الحمد الله رب العالمين الذى جعل الصلاة عماد الدين وجطها صلة قوية

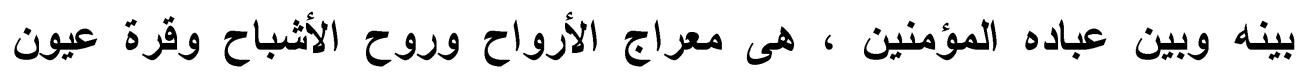

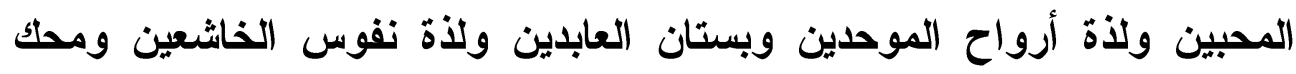

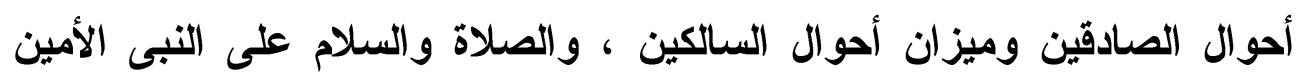

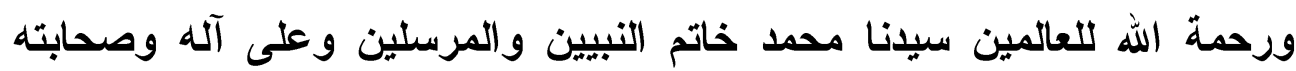

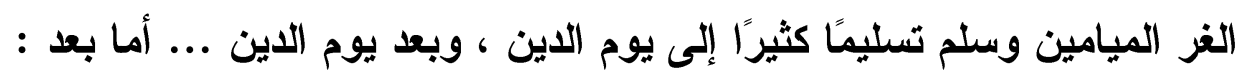

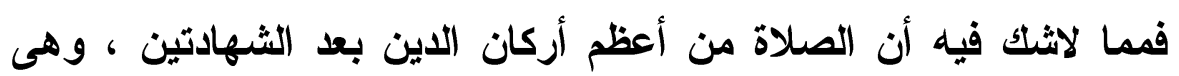

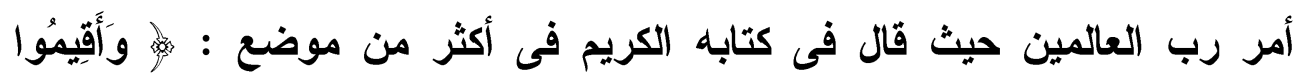

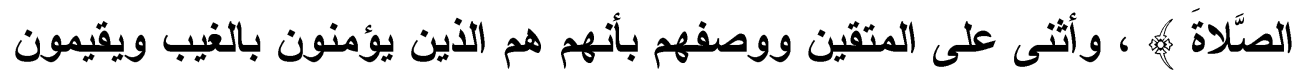

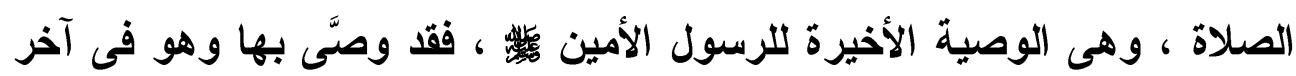

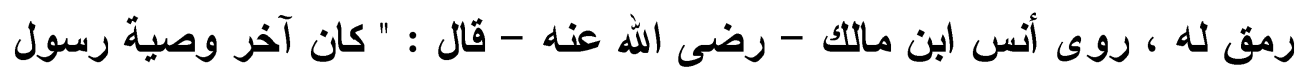

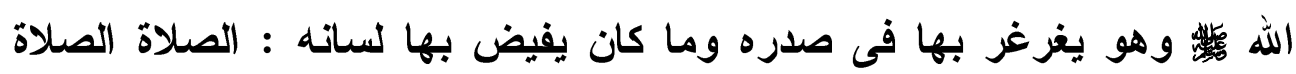

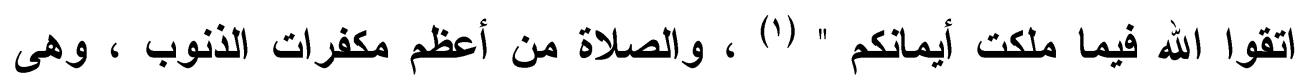

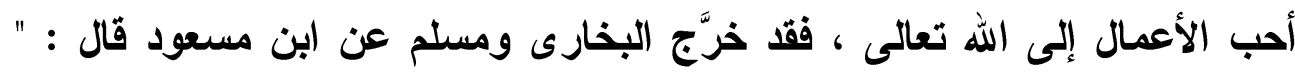

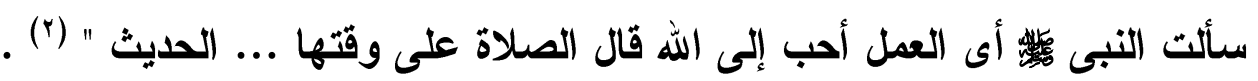

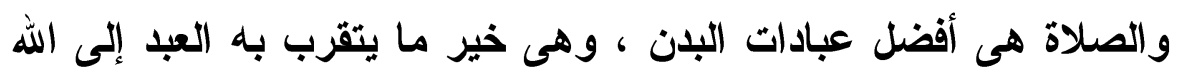

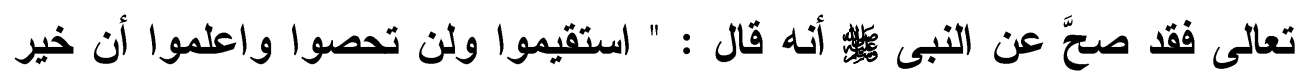

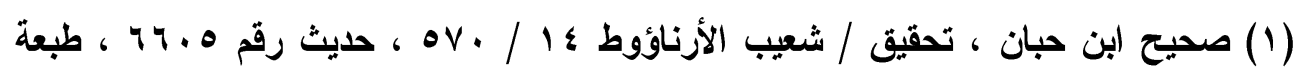

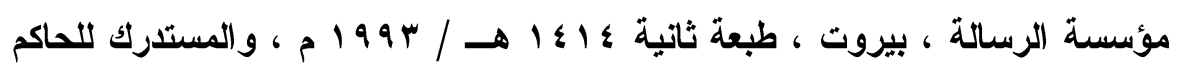

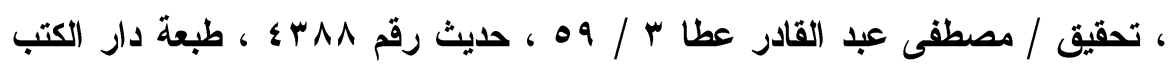

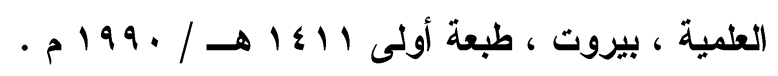

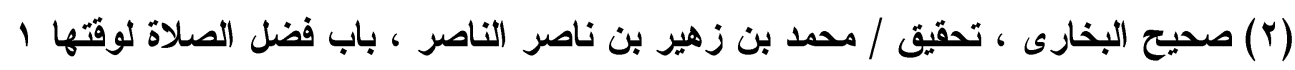

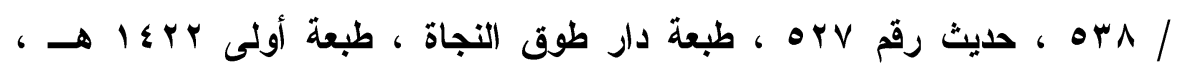

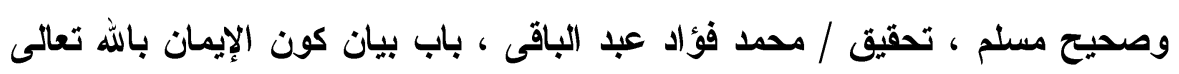

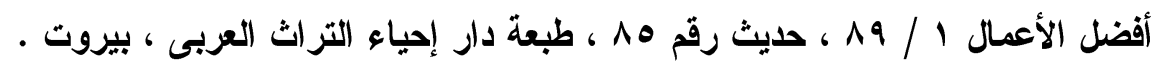




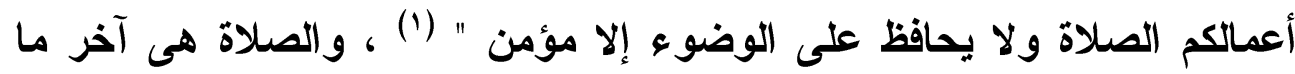

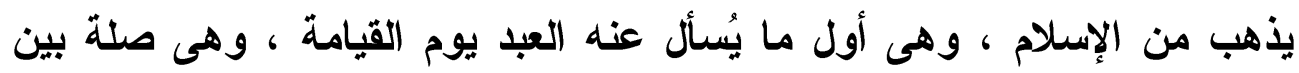

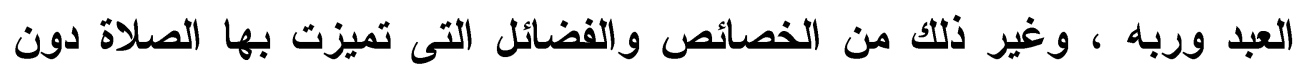

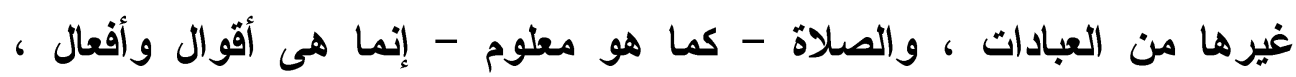

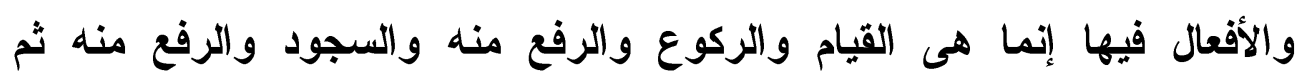

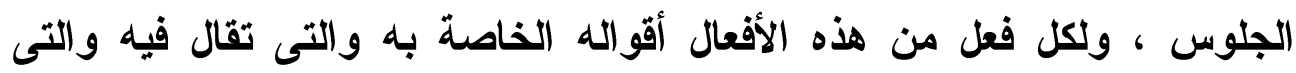

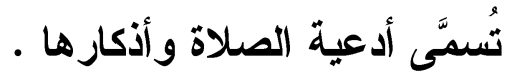

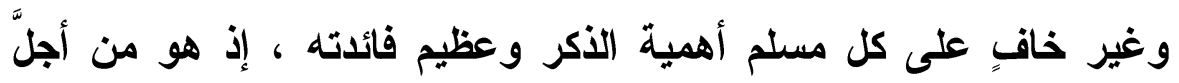

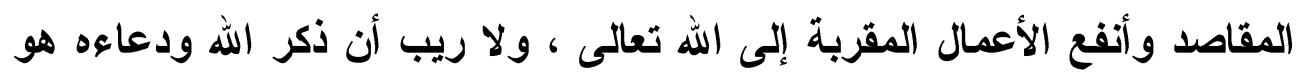

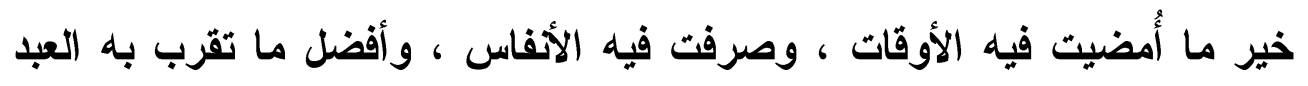

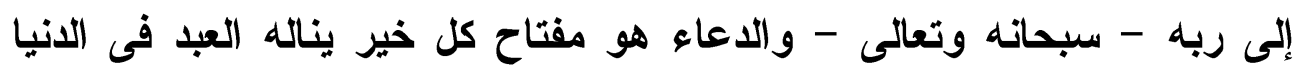

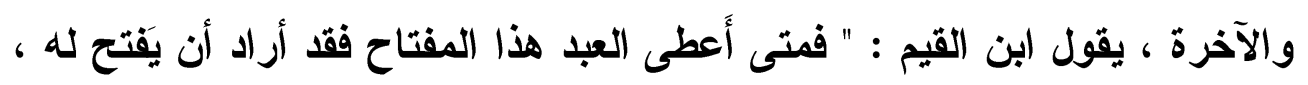

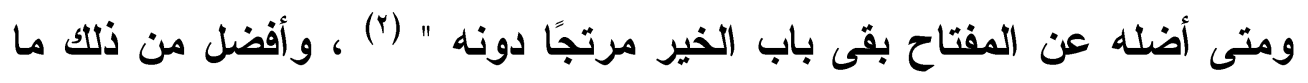
ذكره النبى

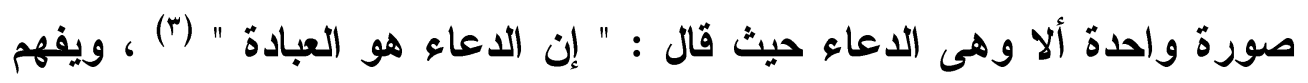

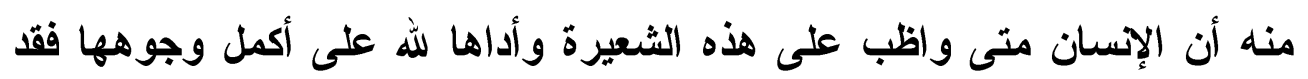

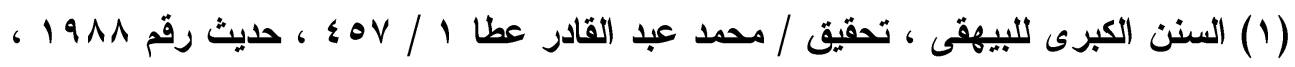

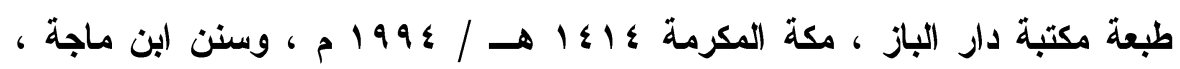

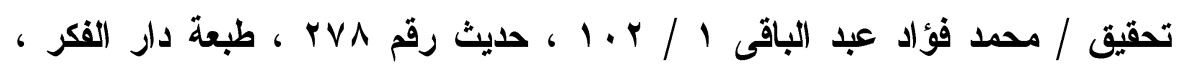

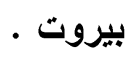

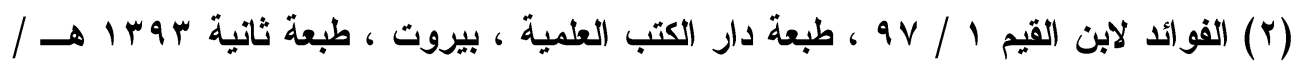
. 19Vr

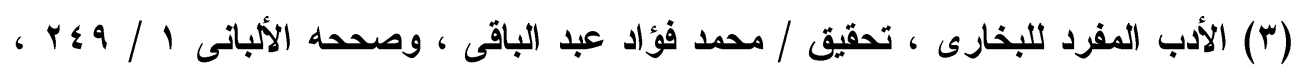

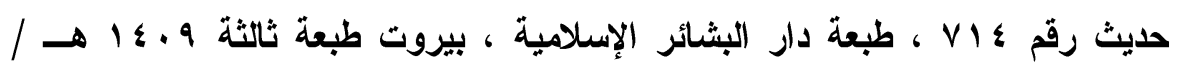

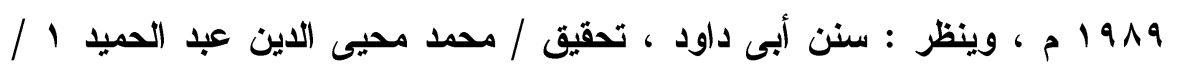

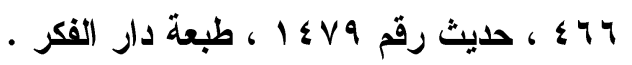


ترقى فى مدارج الكمال واقترب من رحمة الكبير المتعال .

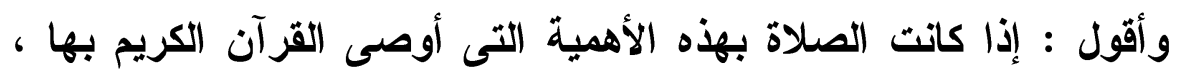

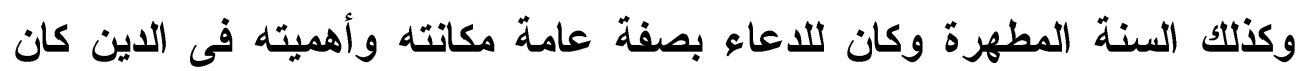

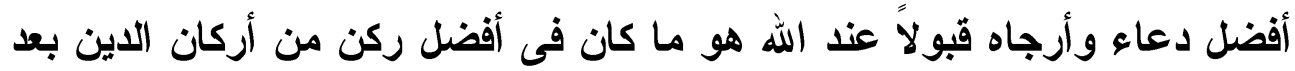

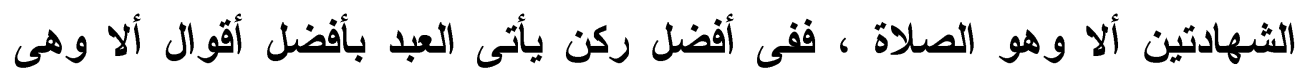

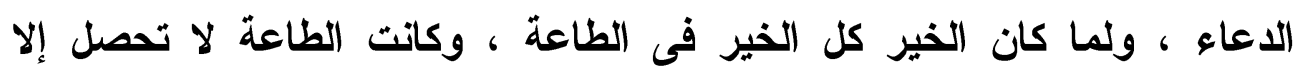

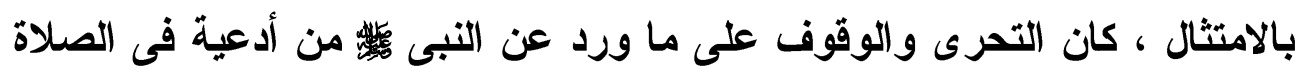

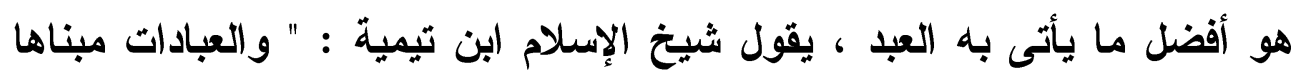

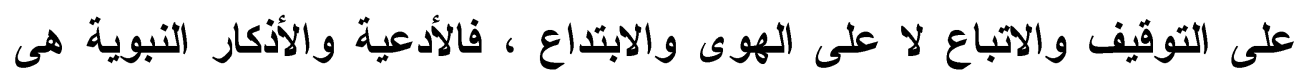

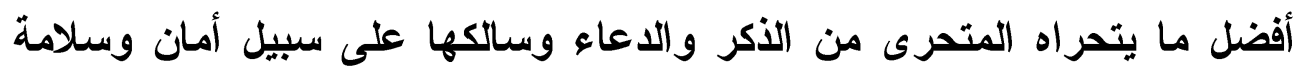

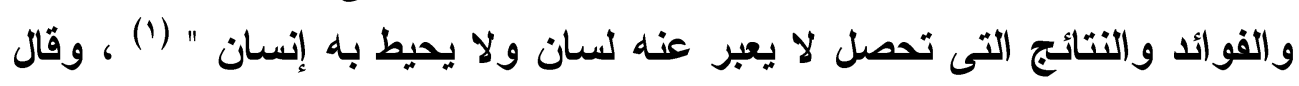

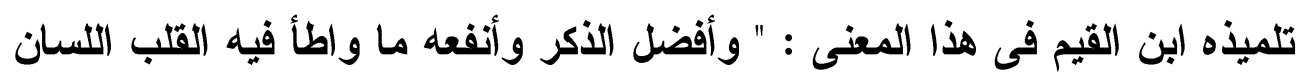

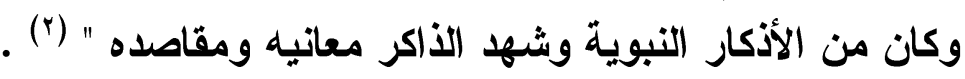

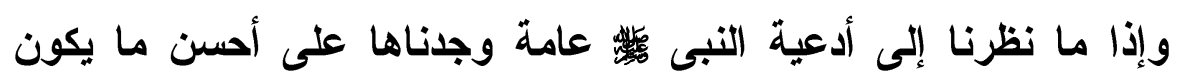

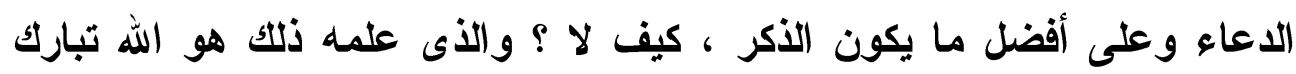

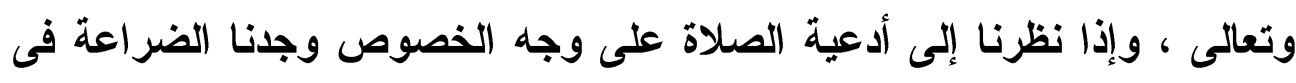

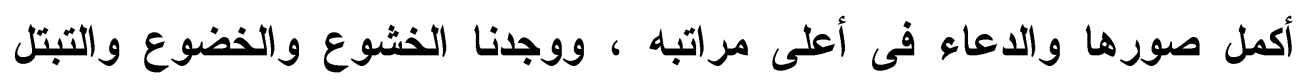

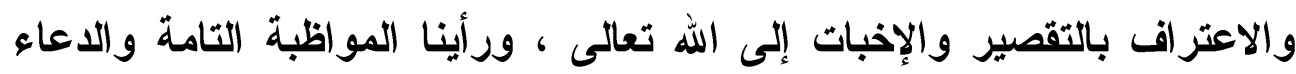

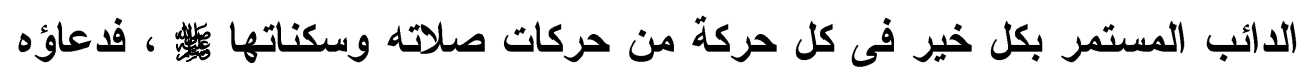

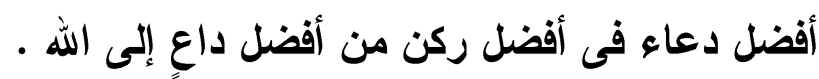

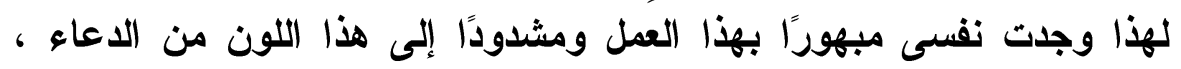

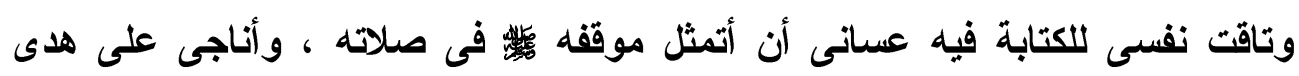

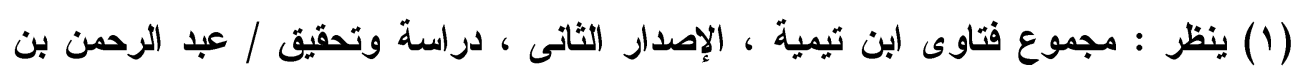

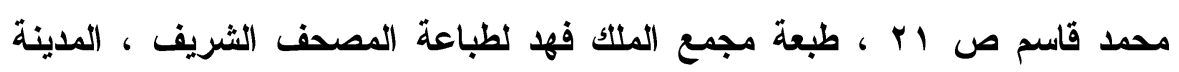

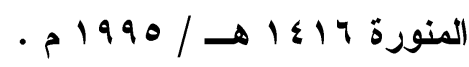

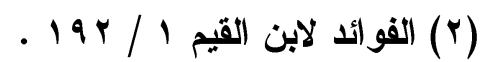


مناجاته ، وأضرع على نحو ضر اعاته ، فاستخرت الله العظيم ودعوته أن يوفقنى فى ألى

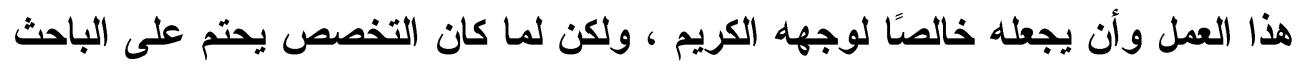

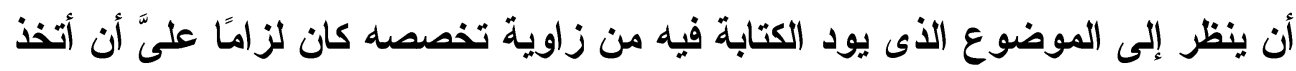

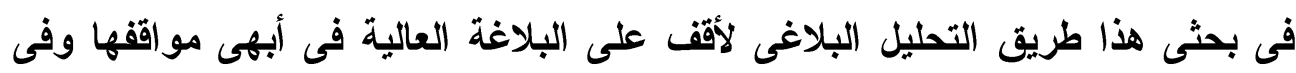

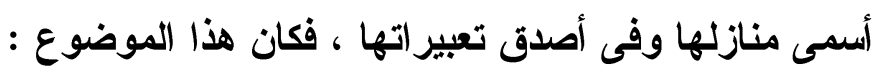

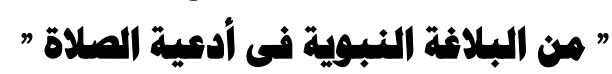

هذا وقد اقتضت طبيعة البحث أن يأتى فى ستة مباحث يسبقها مقدمة وتمهيا

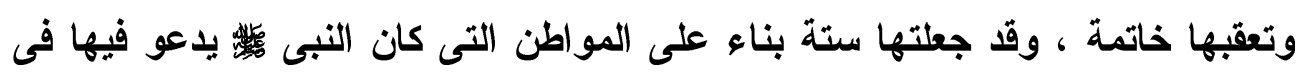

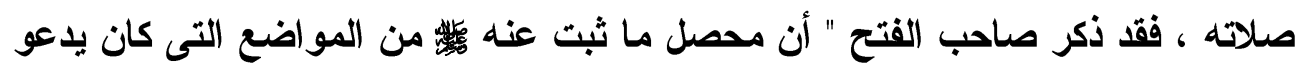

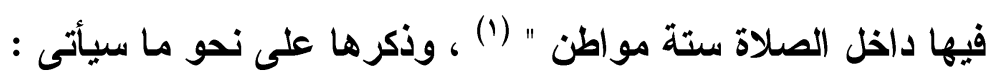
المبحث الأول : تعرضت فيه لما يقال من الاعاء عقب تكبيرة الإحرام. والمبحث الثانى : ما يقال من الاعاء فى الركوع .

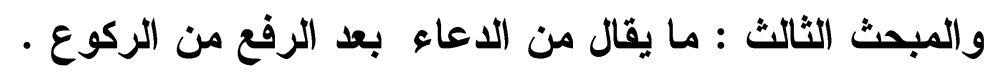

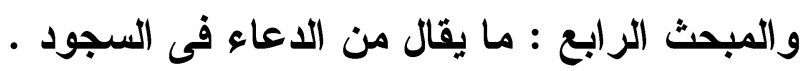
والمبحث الخامس : ما يقال من الاعاء بين السجدتين .

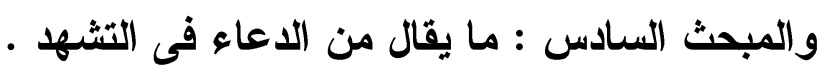
ثم كاتت خاتمة البحث وذكرث فيها ما توصلت إليه من نتائج وفوائد .

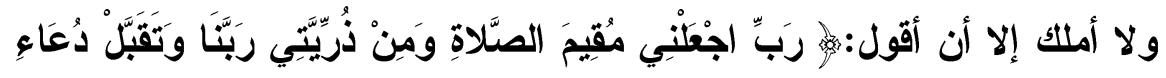

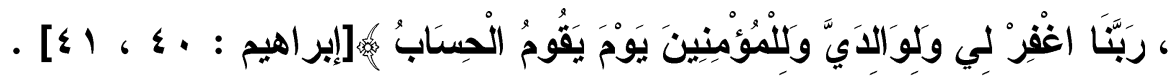
ولقد بذلت فى هذا البحث جهدى وطاقتى - والله يعلم - ولم أدخر فيه وسعًا

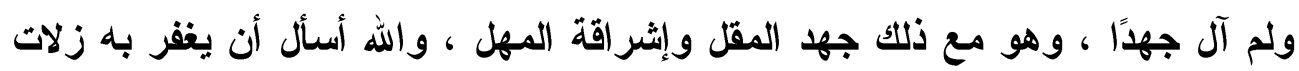

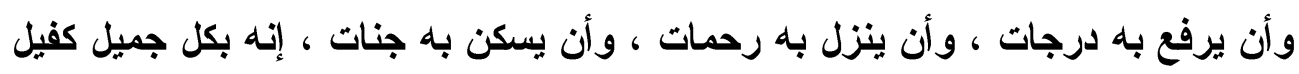

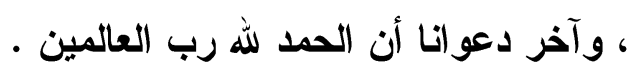

\section{الدكتمد}

على مصمد عبد الرحيم هممد على

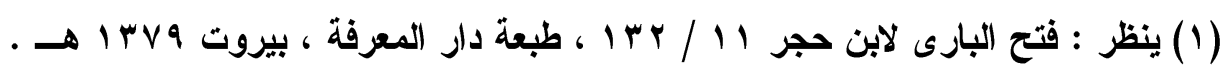




\section{تمهيد}

معلوم أن الصلاة هى الركن الثانى يأتى بعد الثهادتين ، روى البخارى

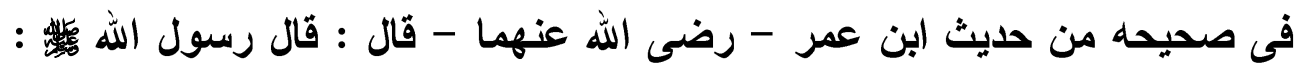
" بنى الإسلام على خمس : شهادة أن لا إله إلا الله وأن محمدًا رسول الله ، وإقام

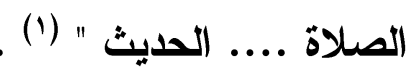

وهى ركن الاين الأعظم وعموده ، وهى أول فروض الإسدلام ، ولا حظ فى الإسلام لمن تركها ، وكل مستخف بها مستهين فهو مستخف بالإسلام مستهين به ، وإنما حظ الناس من الإسلام على قدر حظهم من الصلاة ورغبتهم

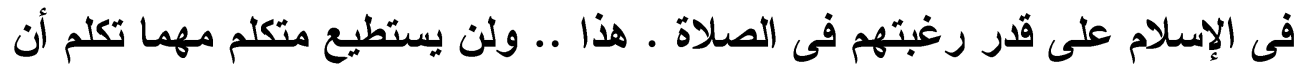
يوفى بحق الصلاة، والآيات القرآنية ، والأحاديث التبوية فى هذا المجال المجال أكثر من

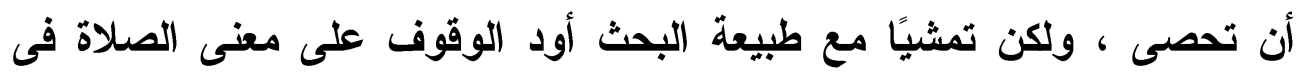

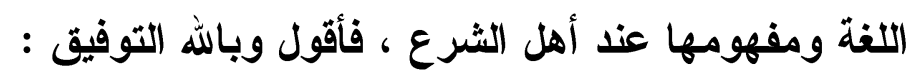
هفهمر الملاة فى اللغة وفى الهشرع :

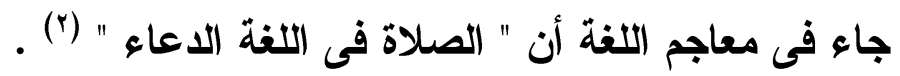
وفى الشرع : " هى عبارة عن هيئات وحركات وأقوال وأفعال تبدأ بالتكبير وتنتهى بالتشليم " (r) .

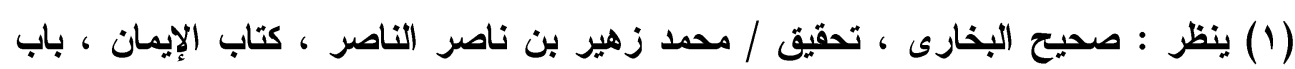

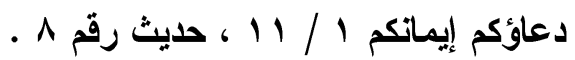

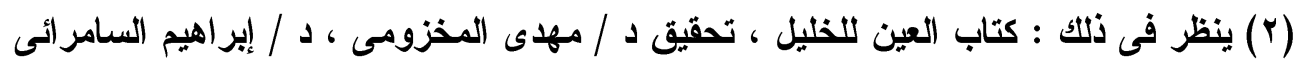

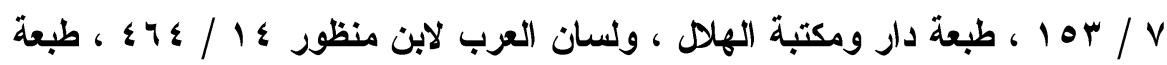

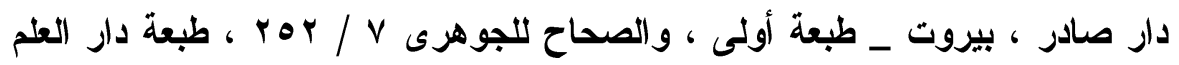

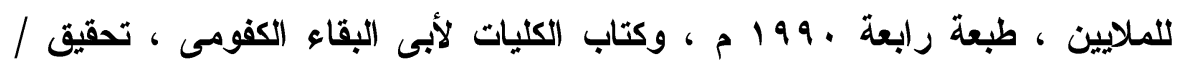

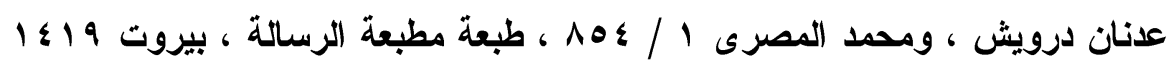

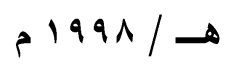

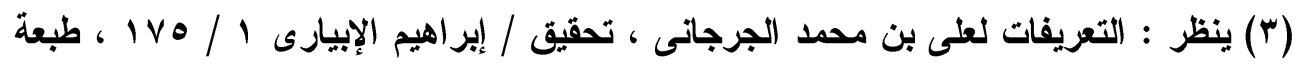

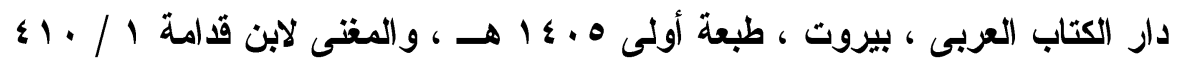




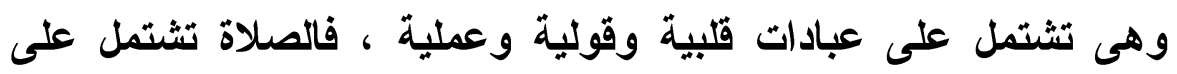

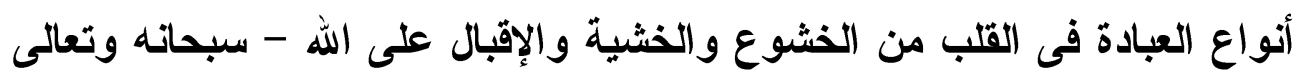

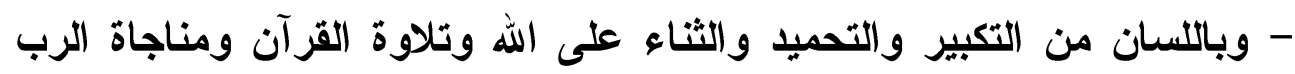

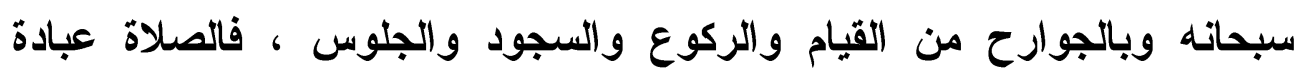

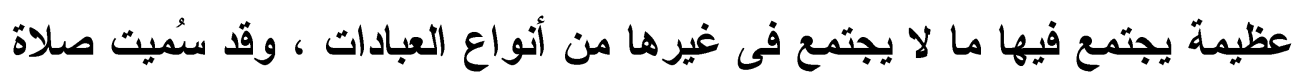

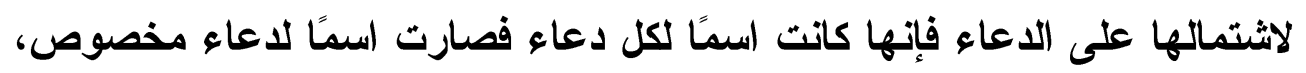

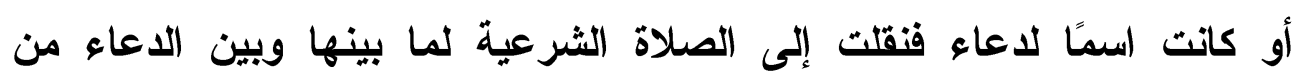

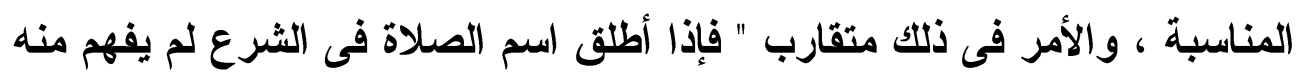

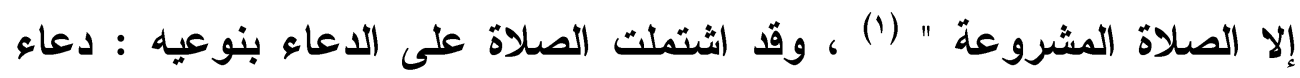

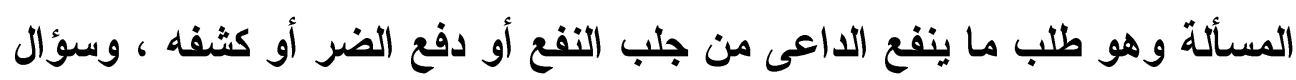

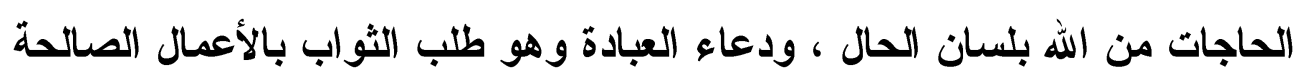

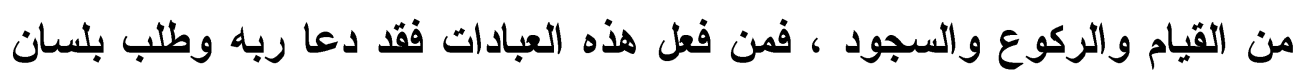

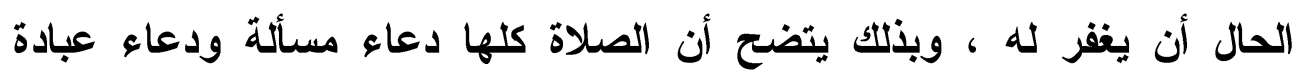

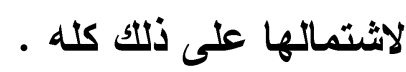
الدعاء فى اللغة وفى الشرع : أما الاعاء فقد ورد فى معاجم اللغة بمعنى الصياح وبمعنى النداء يقال "

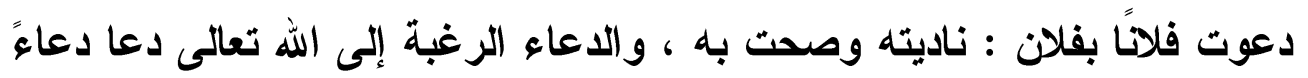

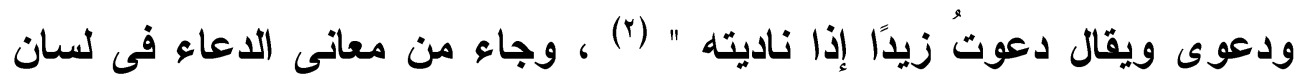

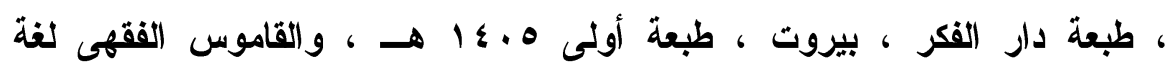

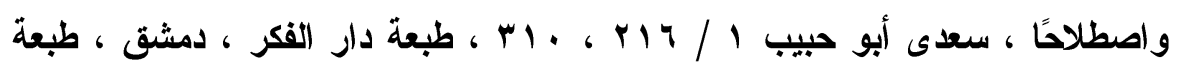

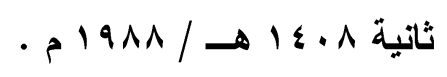

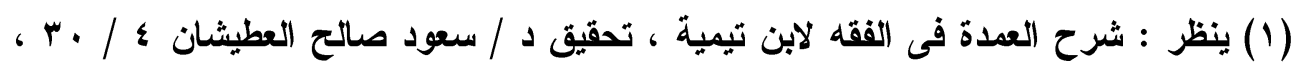

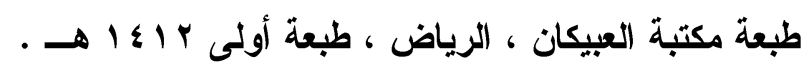

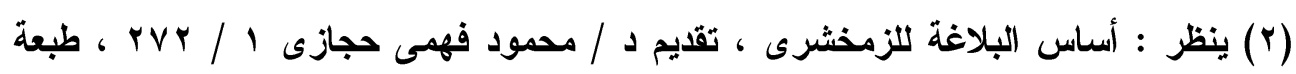

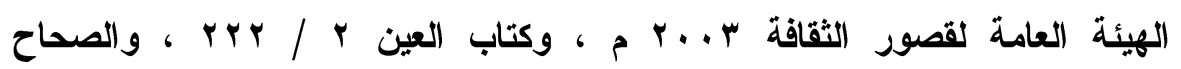

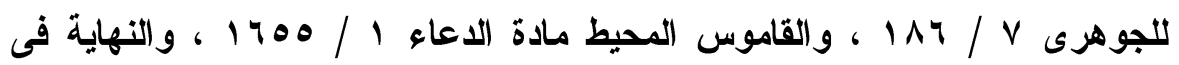




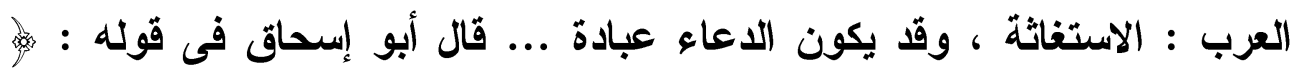

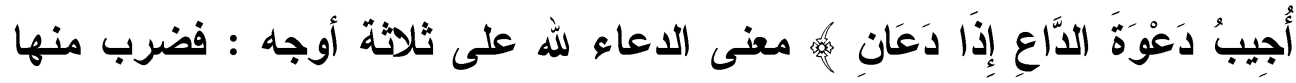

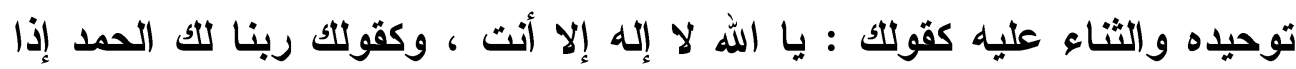

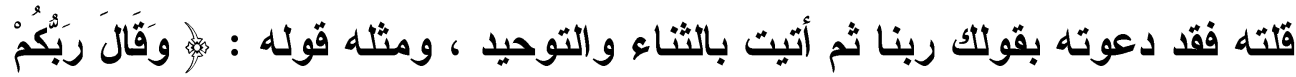

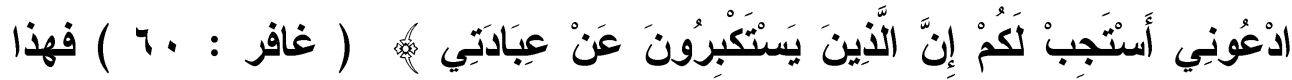

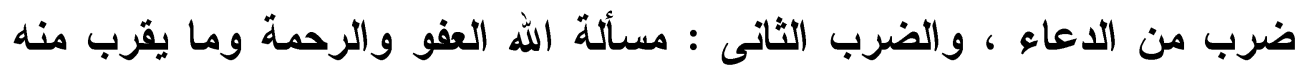

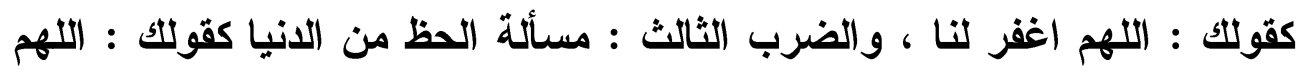

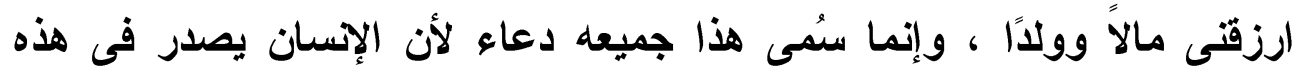

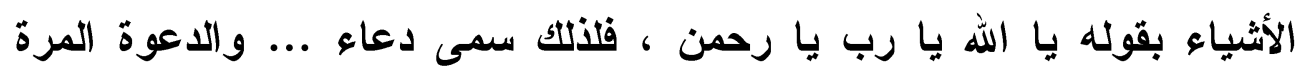

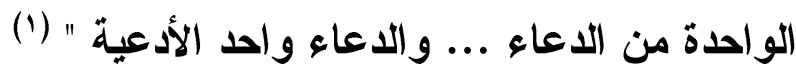

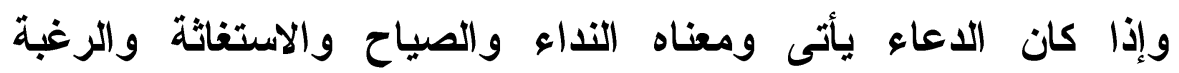
والعبادة، فقد فرق أبو هلال العسكرى بين الدعاء وبين أثهر معانيه وهو النداء

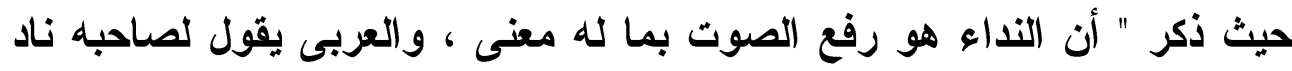

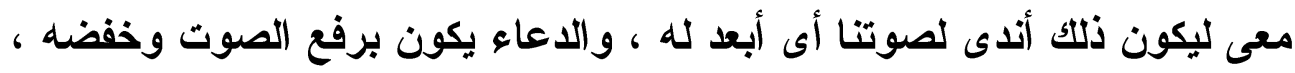

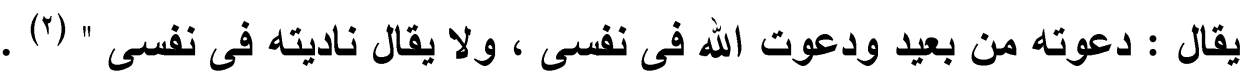

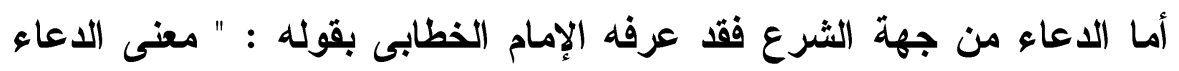

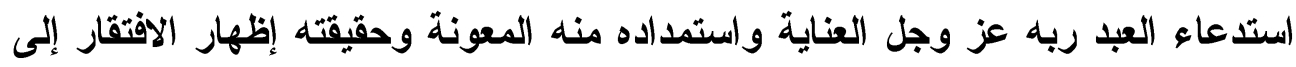

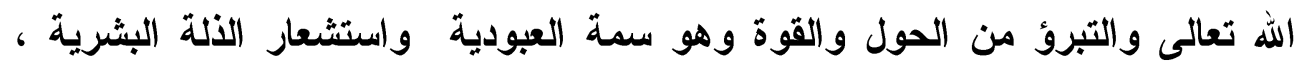

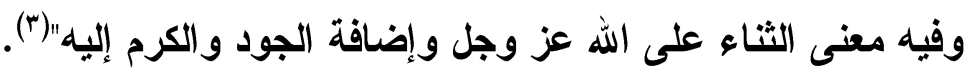

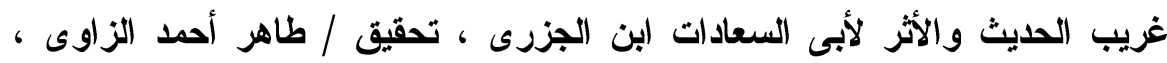

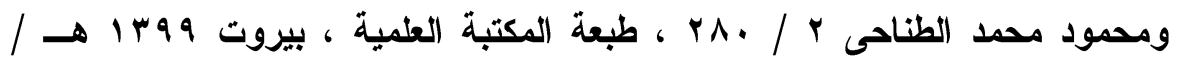

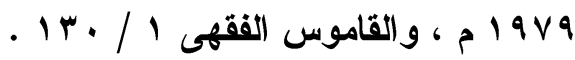

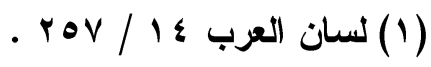

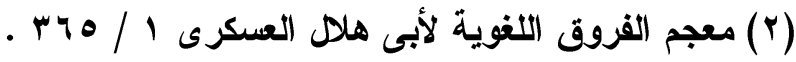

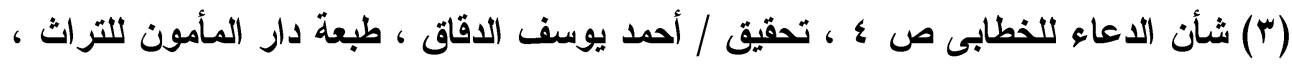

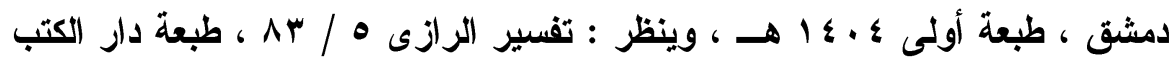




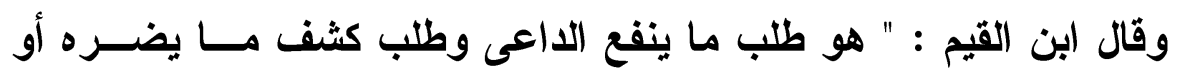

دفعه " (1)

بعد هذا يطيب لى أن أثير فى وجازة إلى فضل الدعاء .

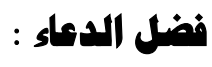

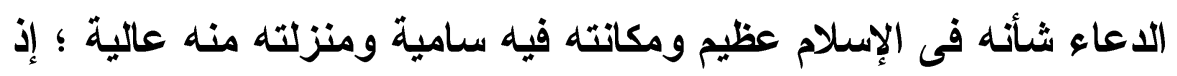

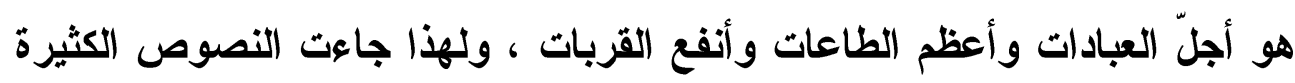

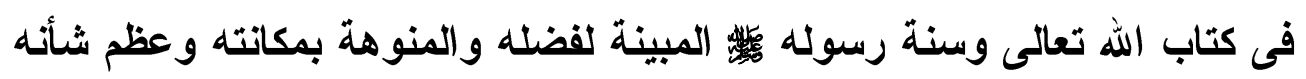

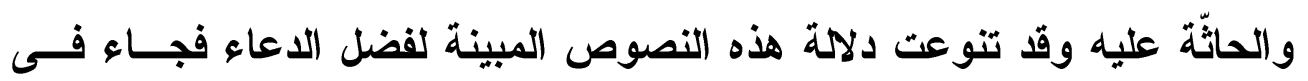

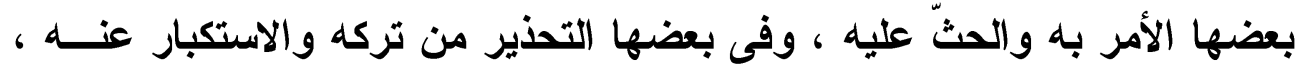

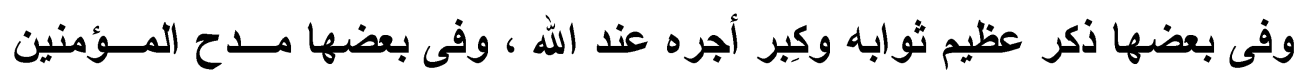

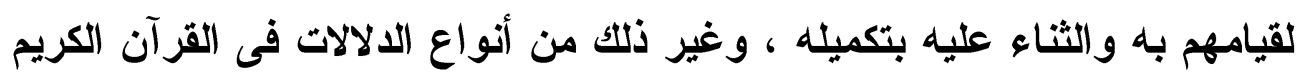

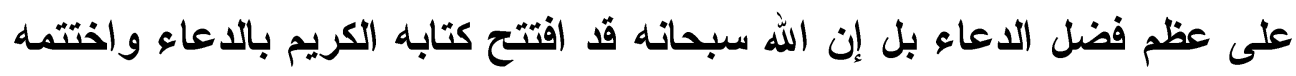

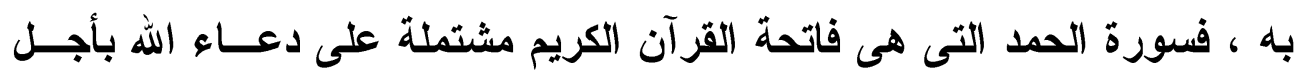

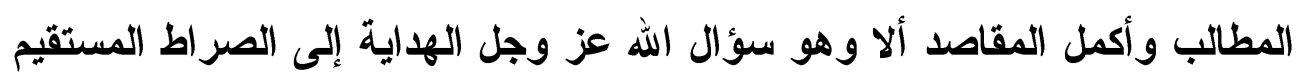

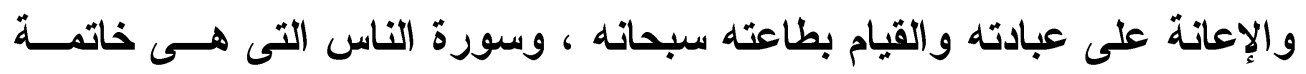

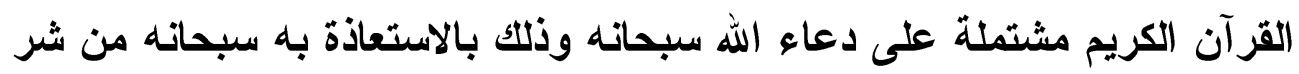

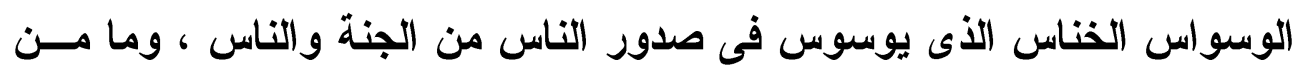

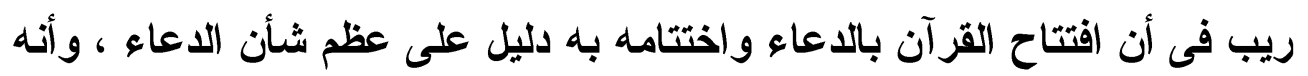

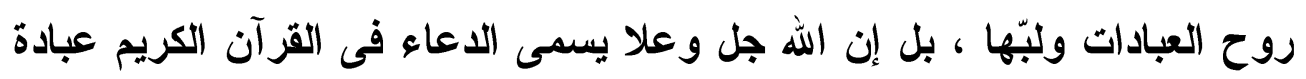

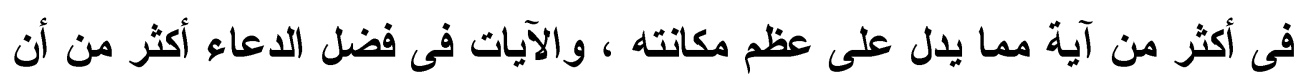

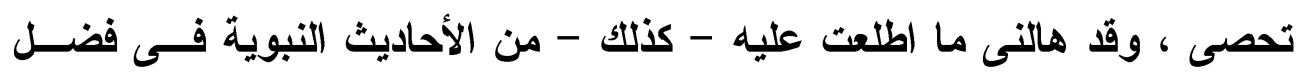

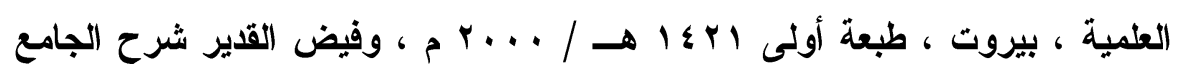

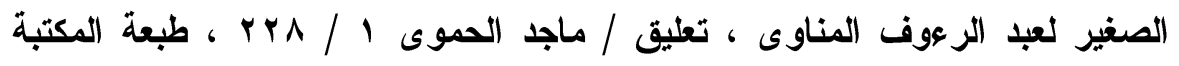

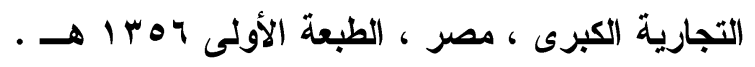
(1) ينظر : بائع الفوائد لابن القيم ؛ / ب ، طبعة دار الكتاب العربى ، بيروت ، لبنان . 
الدعاء وبيان منزلته من الدين .

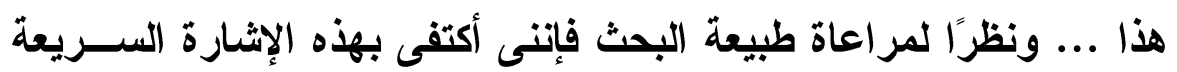

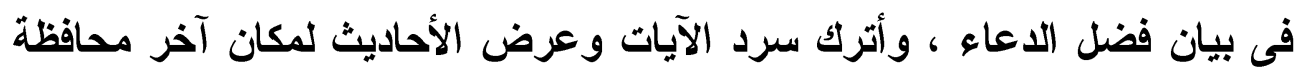

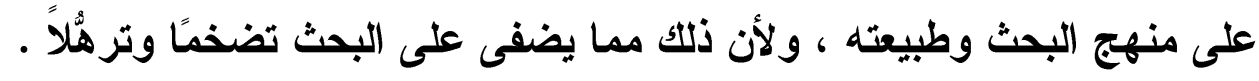

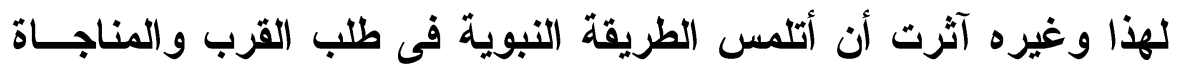

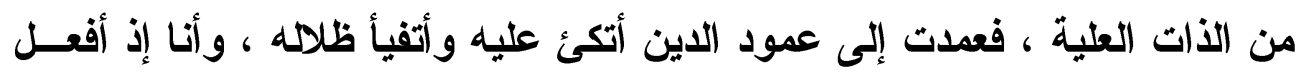

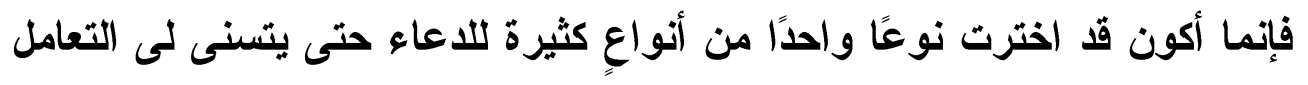

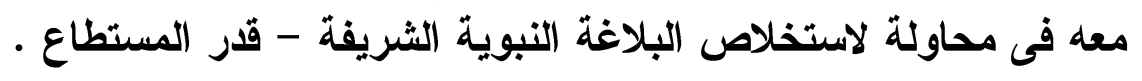

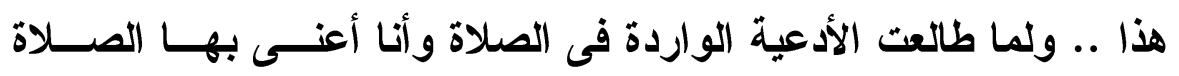

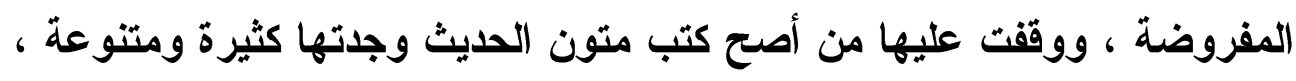

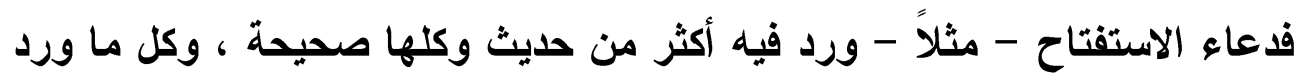

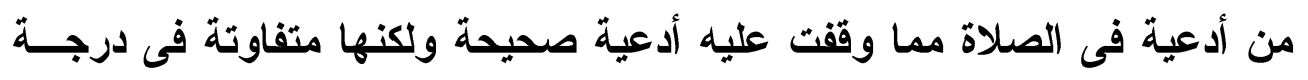

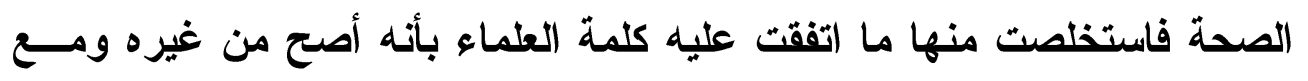

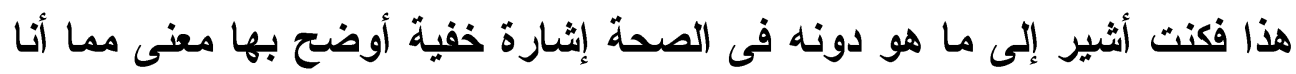

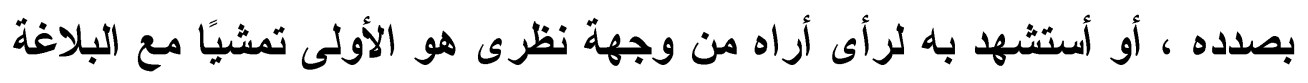

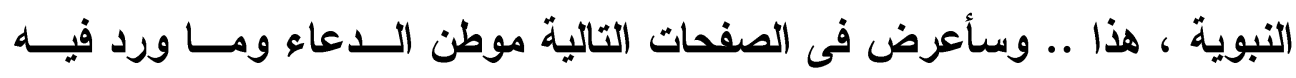

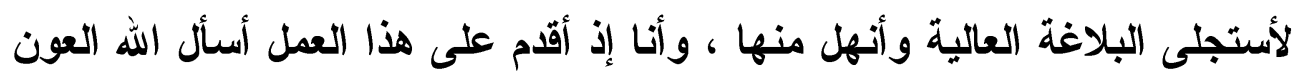

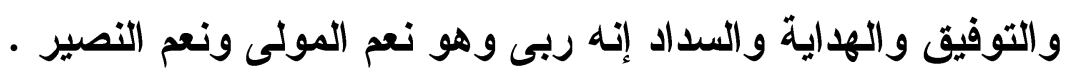




\section{الإبمث الأول \\ ما يقال من الدهاء عقب تكبيرة الإمرام}

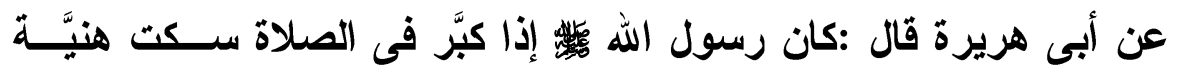

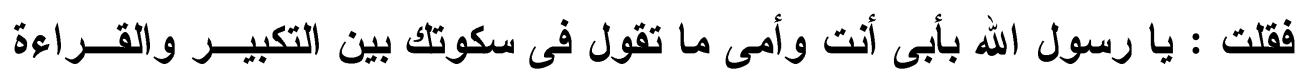

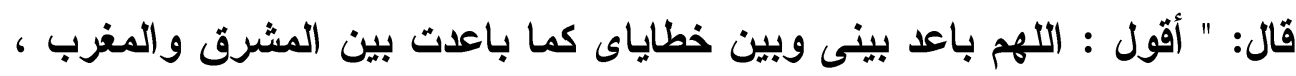

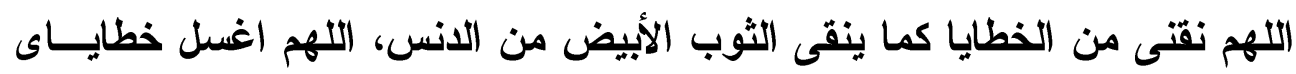

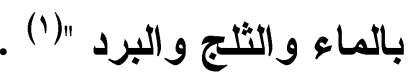

هذا الحديث الثريف هو فى جملته دعاء فى غاية المناسبة فى هذا المقام

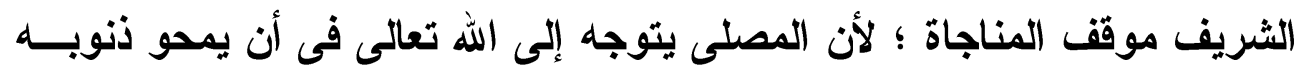

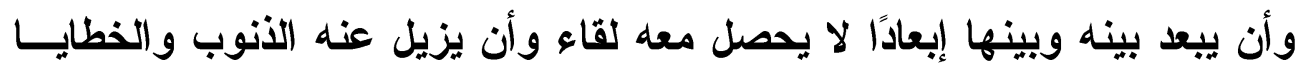

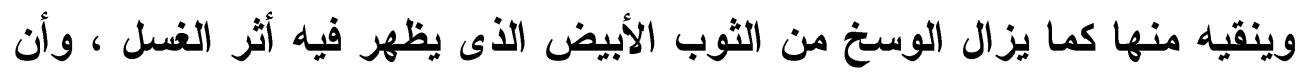

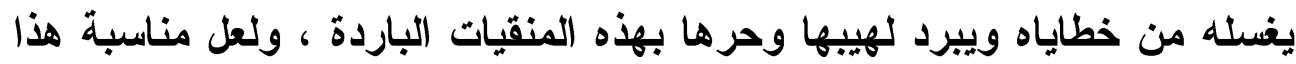
الادعاء بعد الوقوف بين يدى الله وبعد التكبير للصلاة أن الإنسان لا يغيب عنه هذه وفئه

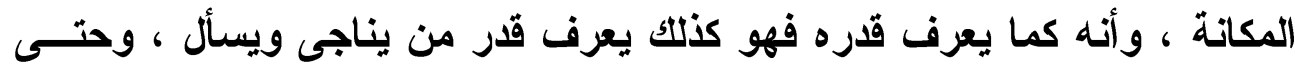

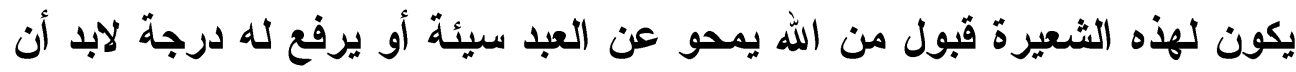
يخلع العبد من نفسه كل ميل إلى الهوى ، ويتخلص من كل علوق بالانيا وما فيها

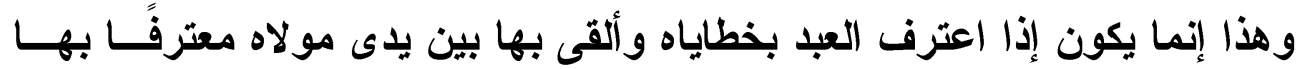

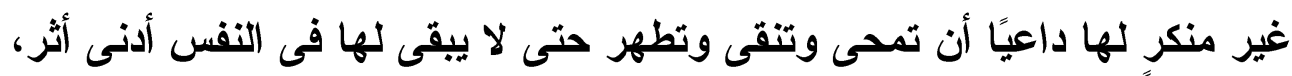

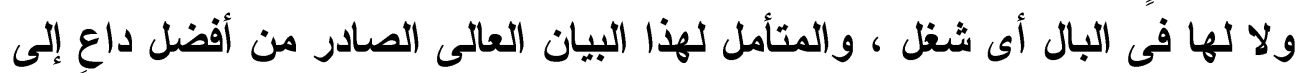

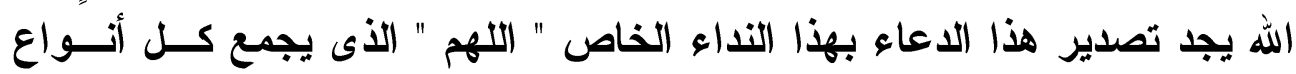

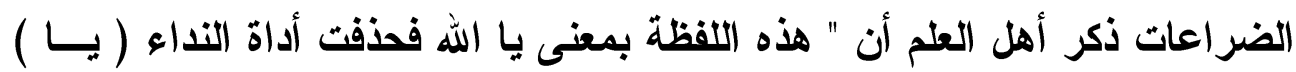

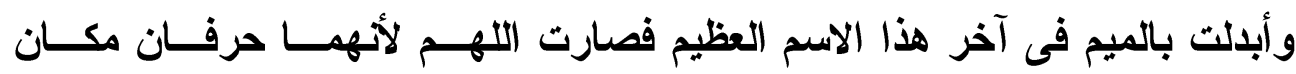

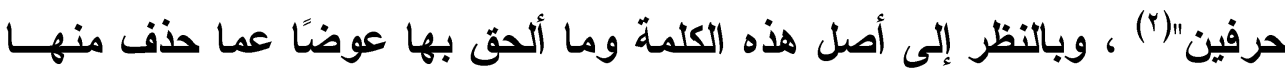

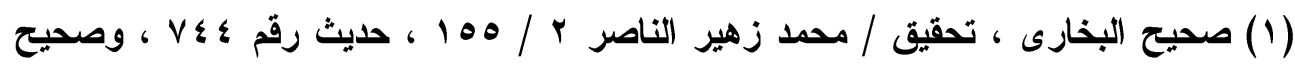

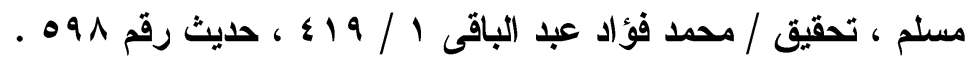

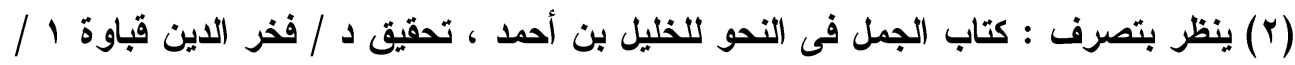

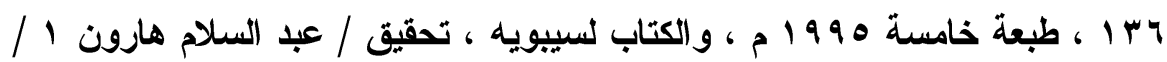


نجد أن هذه الحركة فى بنية الكلمة قد أضفت عليها معنى أعمـق مــن معناهــا

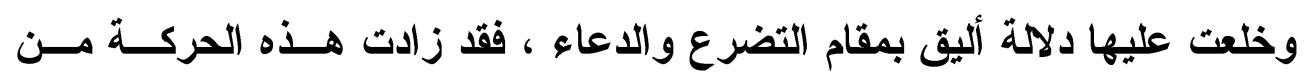

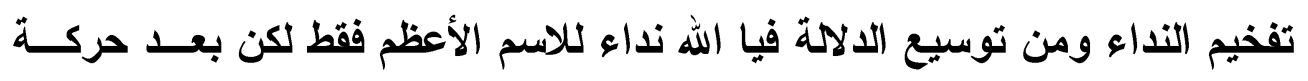

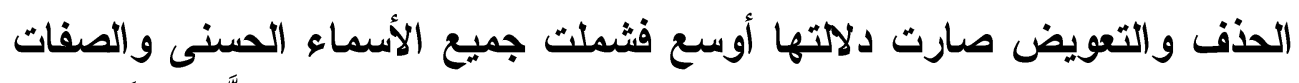

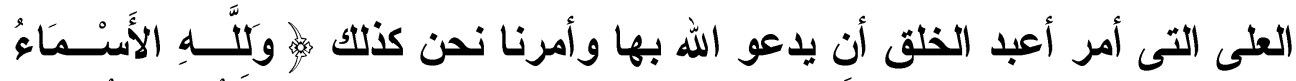

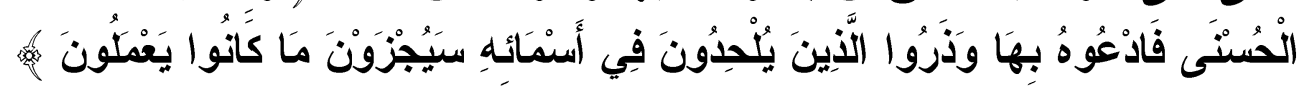

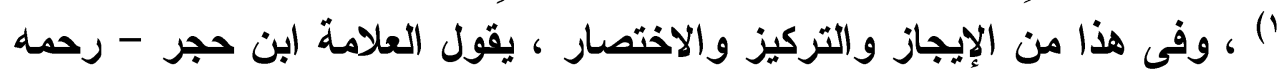

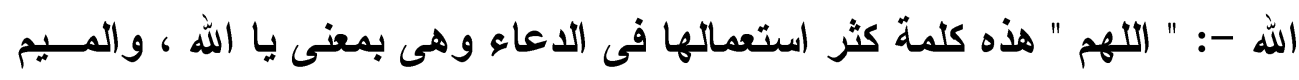

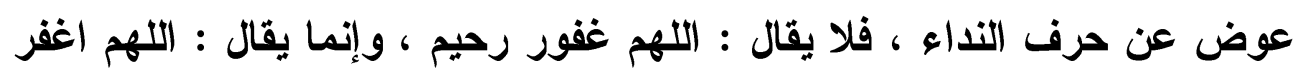

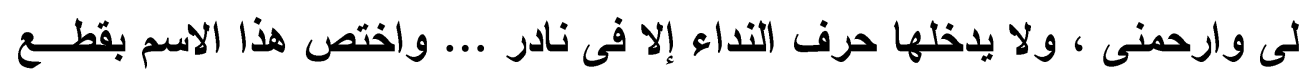

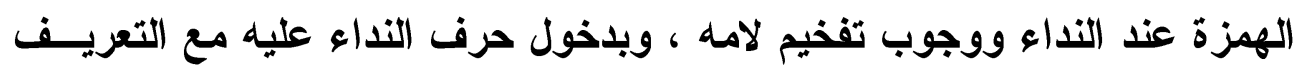

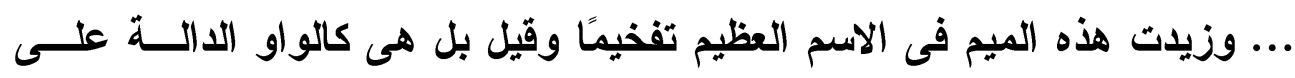

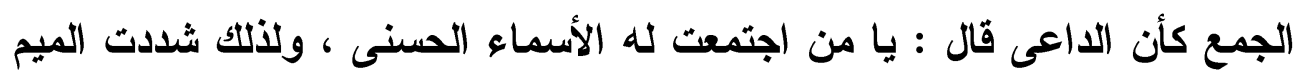

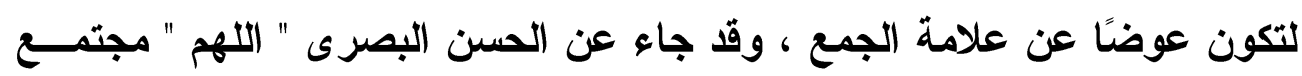
النداء ، وعن النضر بن شميل : من قال اللهم فقد سأل الله بجميع أسمائه " (؟) .

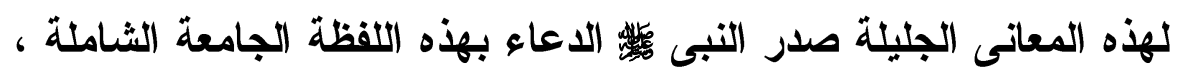

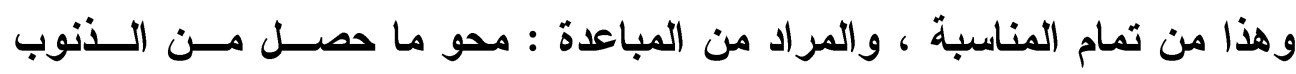

هب ، طبعة دار الجيل ، بيروت ، وكتاب اللمع فى العربية لابن جنى ، تحقيق / فائز

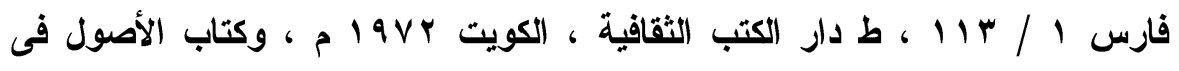

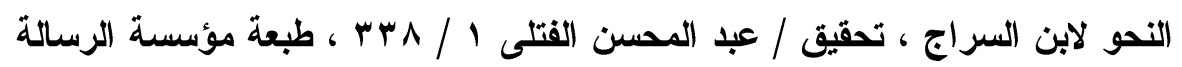

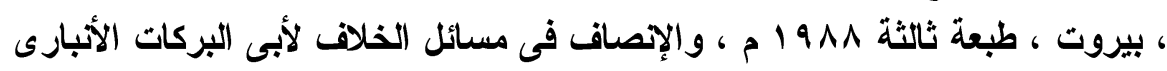

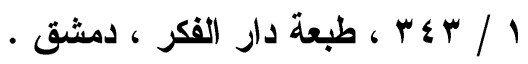

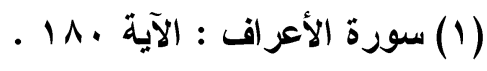

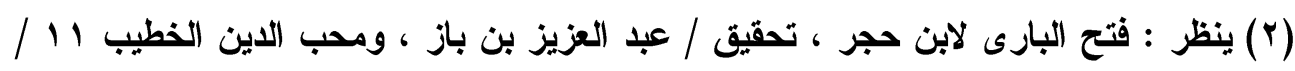

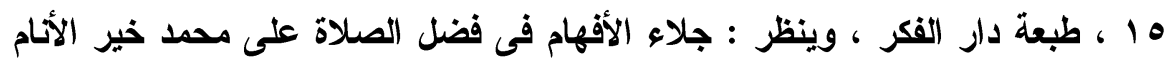

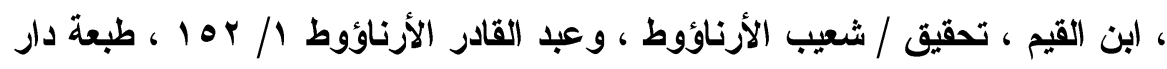

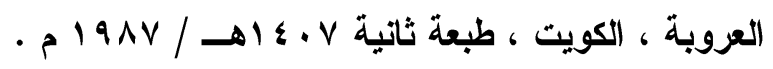


والخطايا والعصمة عما سيأتى منها ، يعنى إن كان المر اد بالأنوب التى اقترفــــ

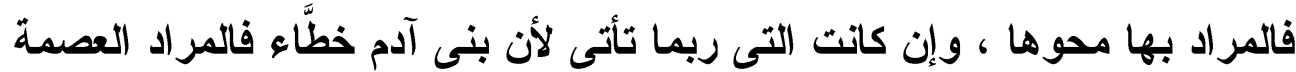

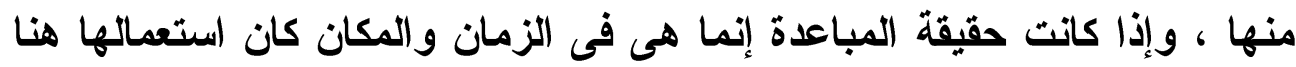

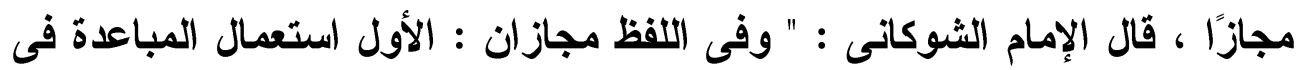

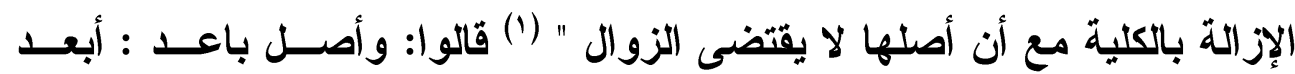

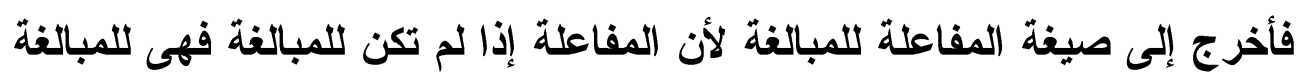

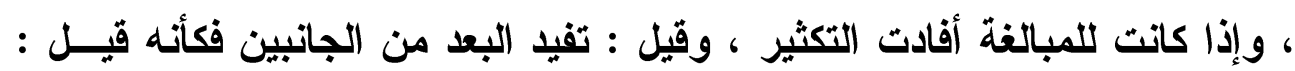

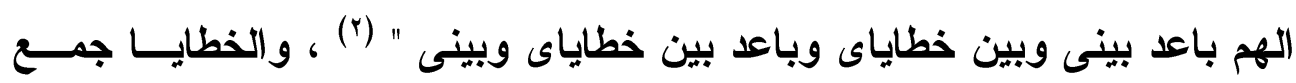

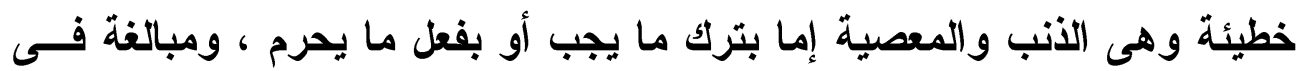

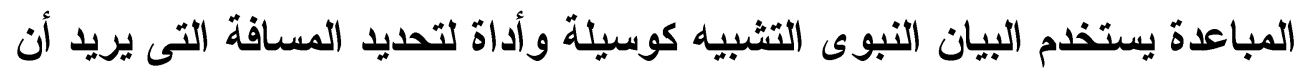
تكون بينه وبين الخطايا حتى يمنعه البعد من اقترافها - كما باعدت بين المشرق واله

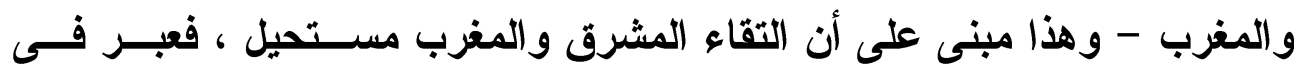

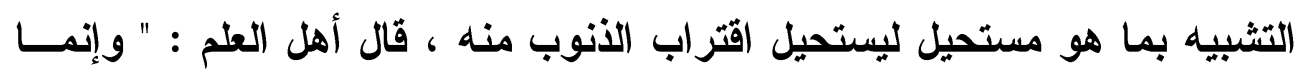

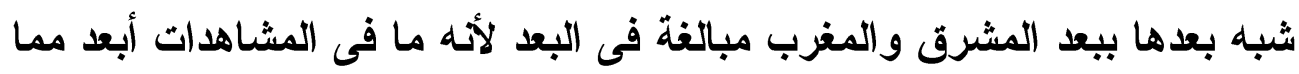

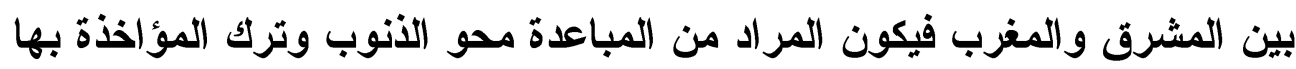

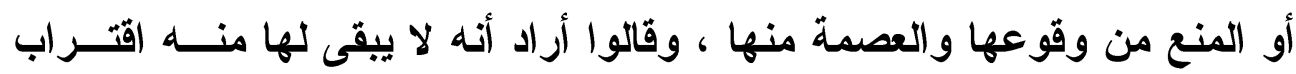

بالكلية " (ن) من من

وفى تصدير هذه الجملة بالنداء العظيم وبفعل الأمر الأى أريد به الــدعاء

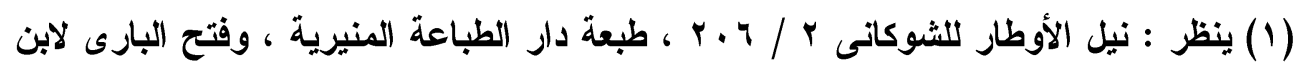

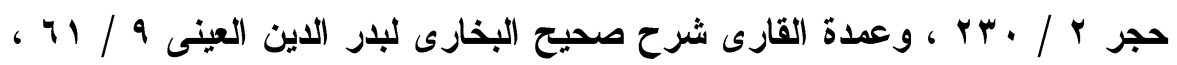

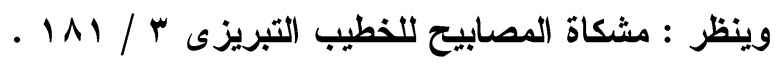

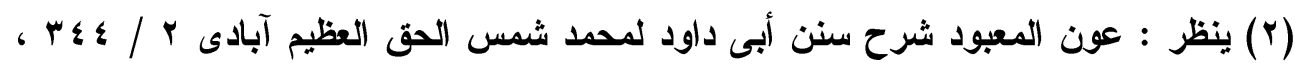

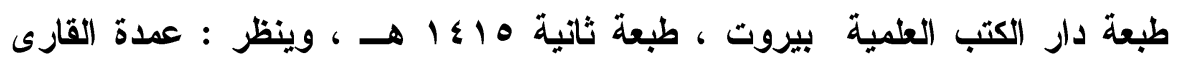

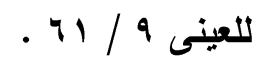

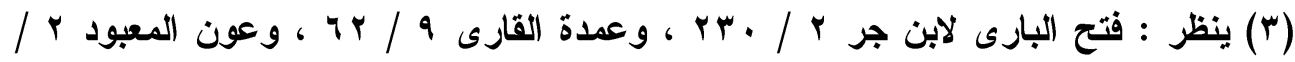

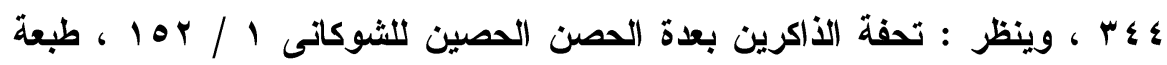

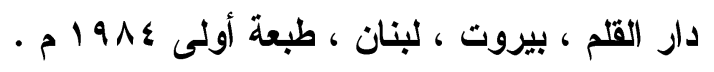




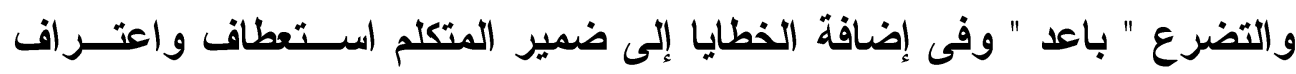

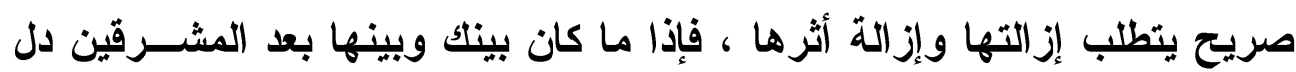

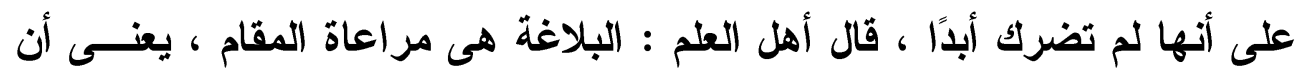

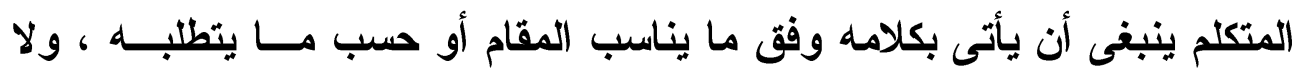

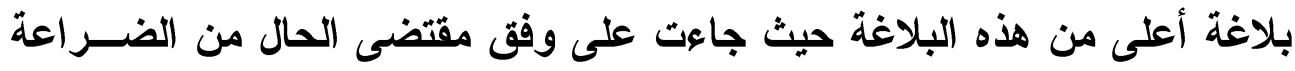

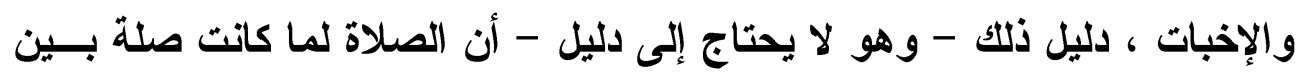

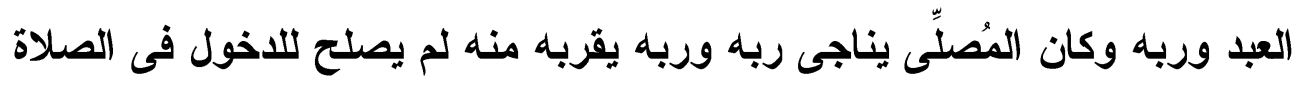

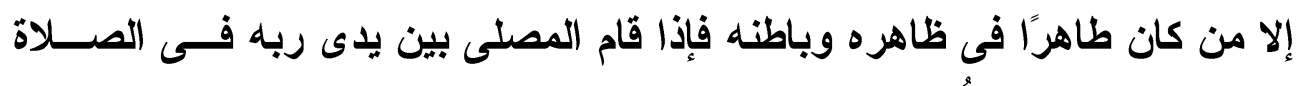

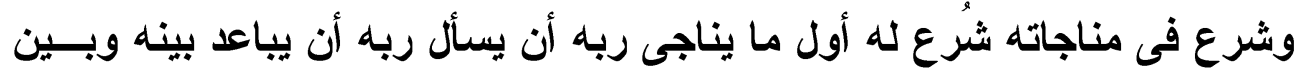

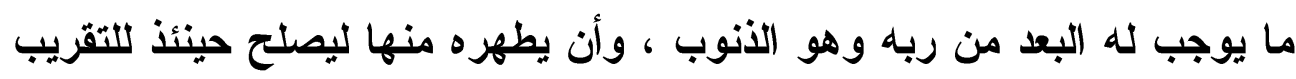

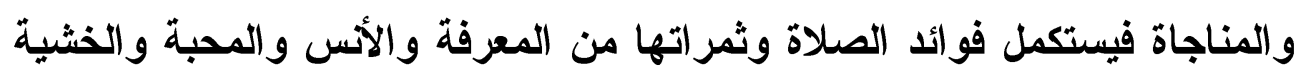

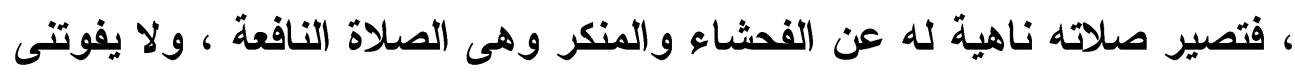

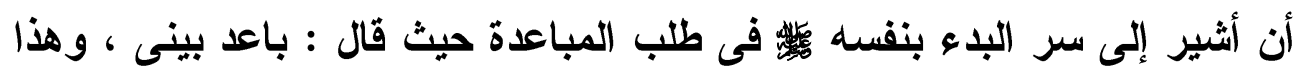

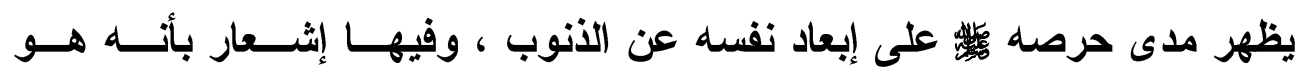

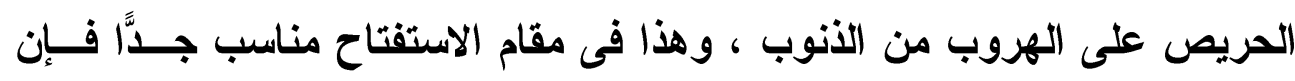

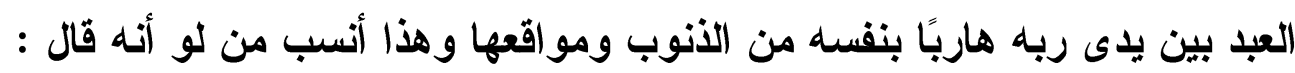

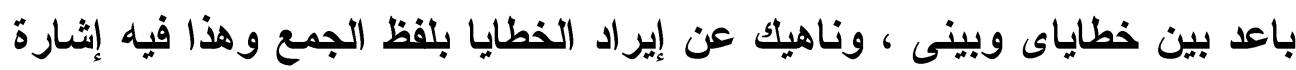

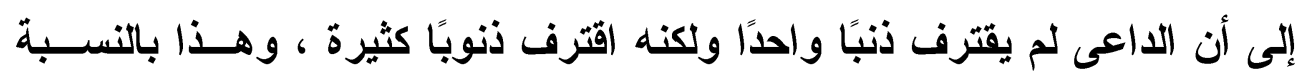
للتبى

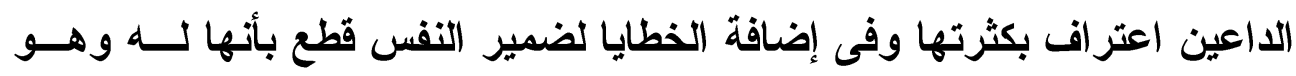

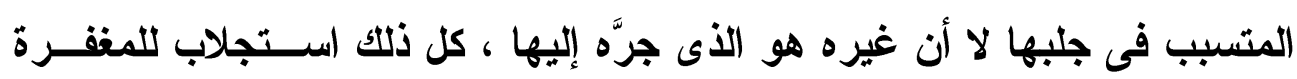

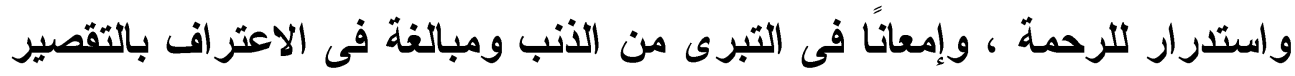

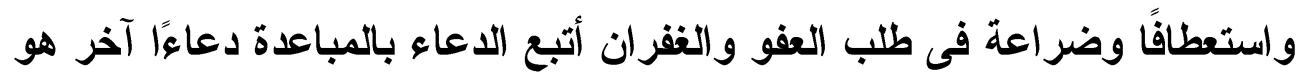

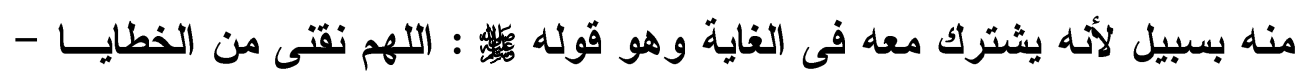

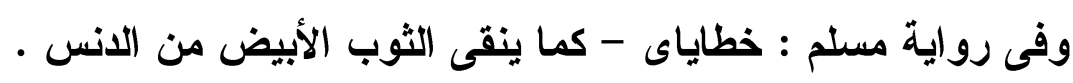




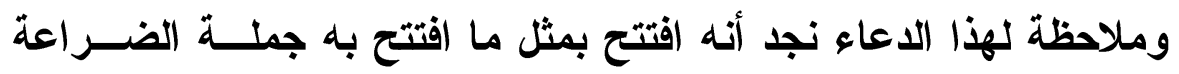
السابقة " اللهم " بالنداء الجامع لكل الأسماء الحسنى حتى يكون ذلتك أرجى للقبول

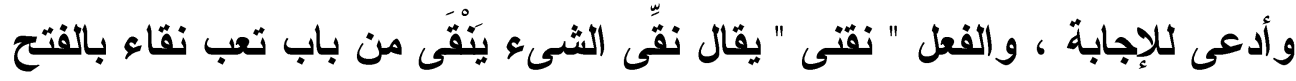

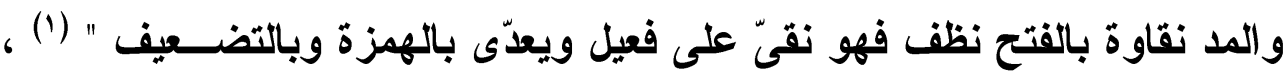

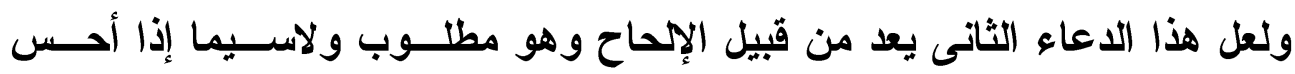

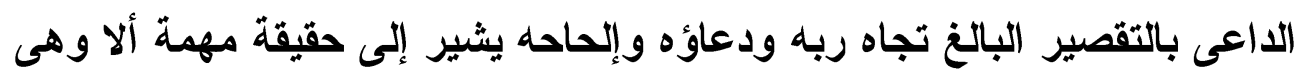

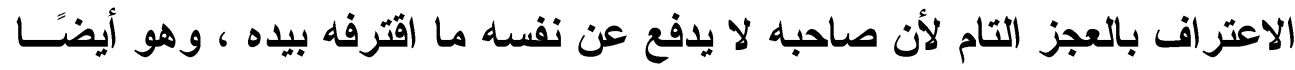

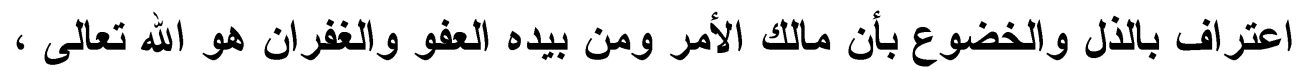

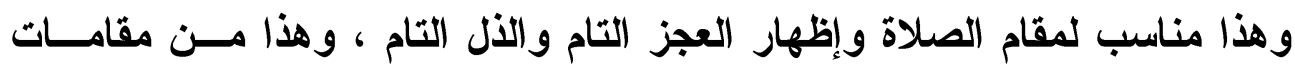

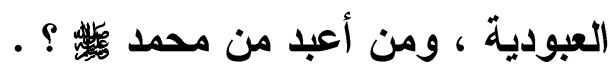

ويتجلى البيان النبوى فى دقة اختيار ألفاظه ، فمادة " نقى " تأتى بـالهمز

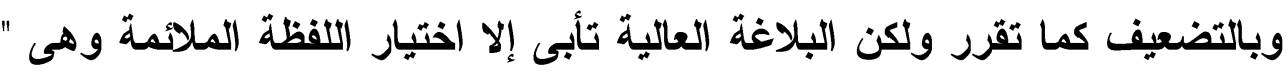

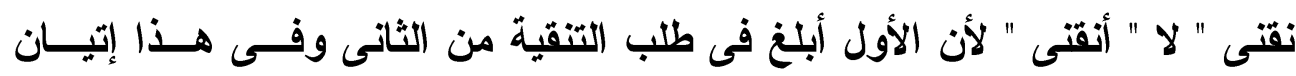

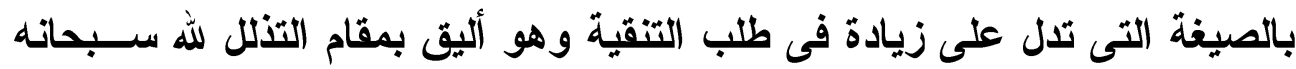

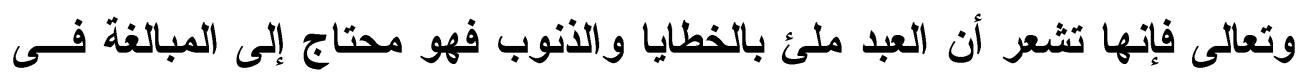

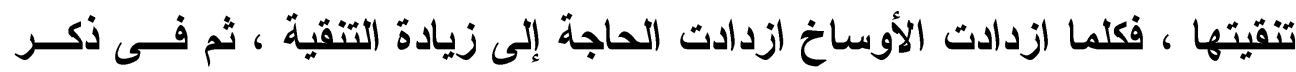

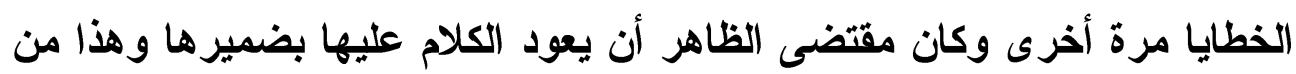

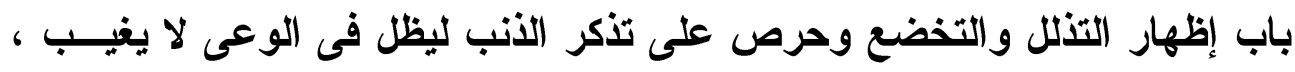

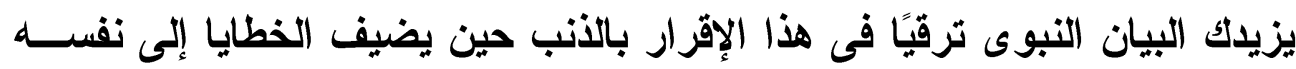

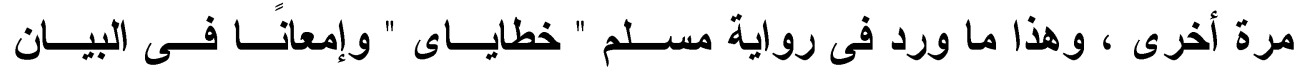

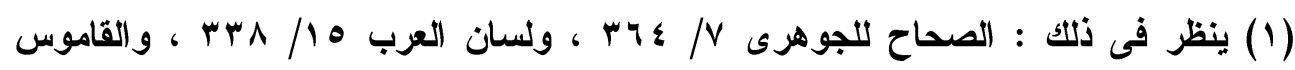

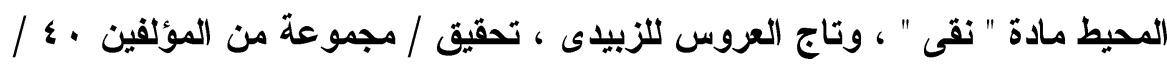

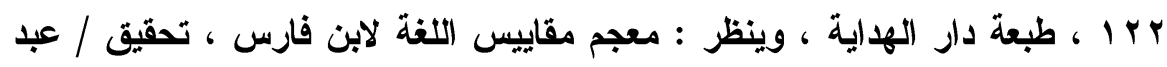

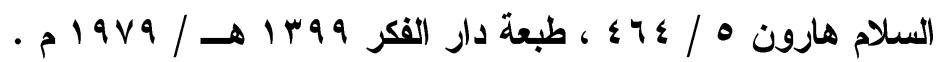




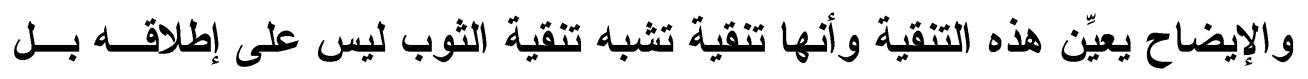

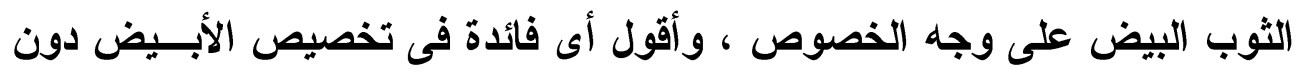

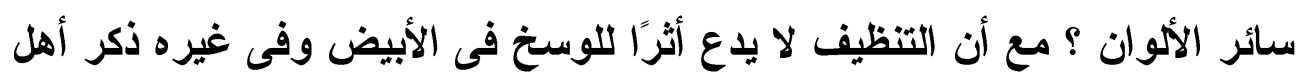

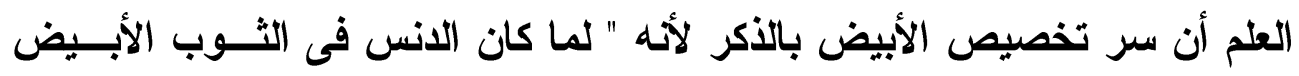

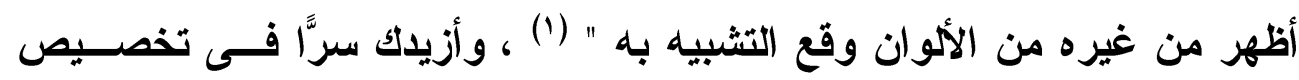

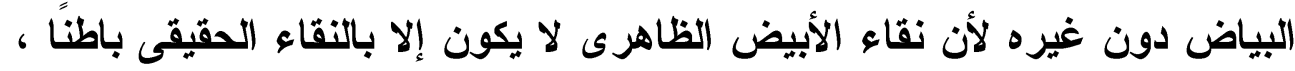

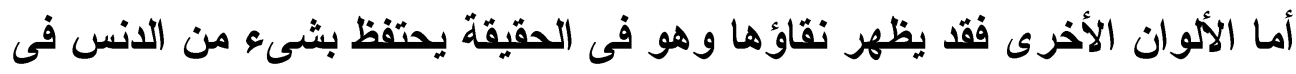

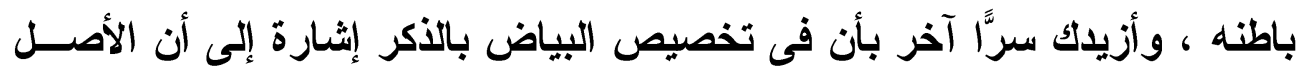

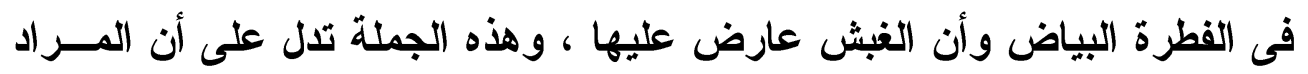

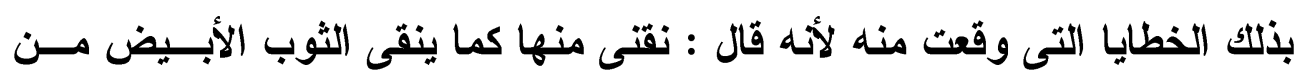

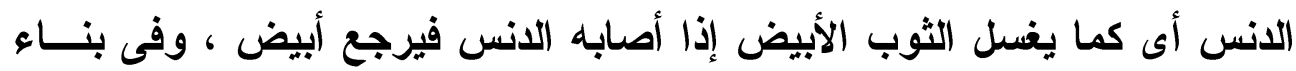

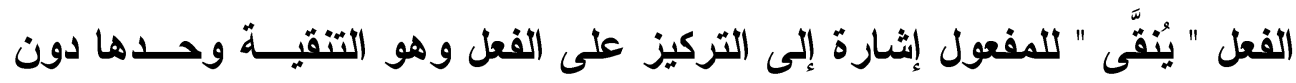

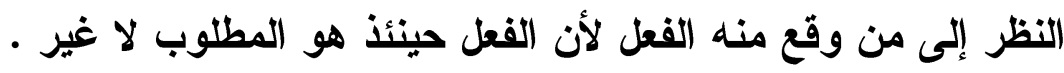

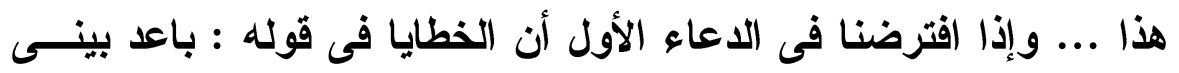

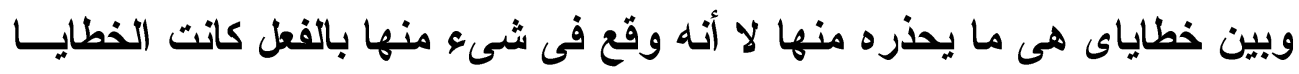

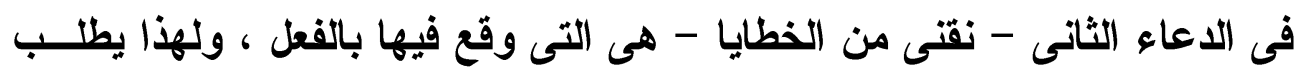

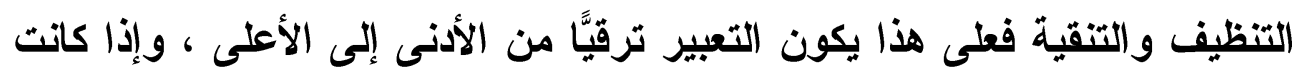

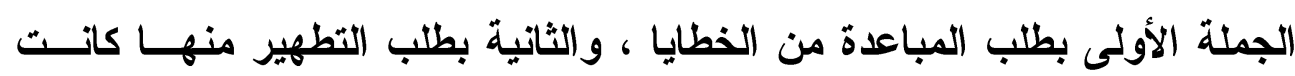

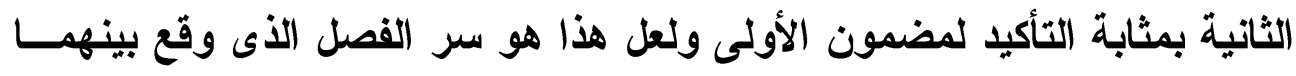

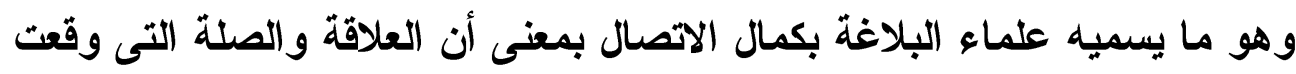

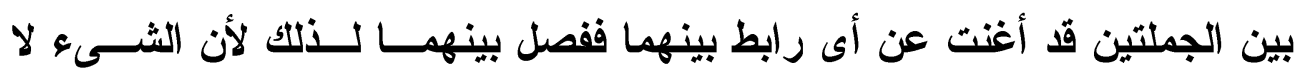

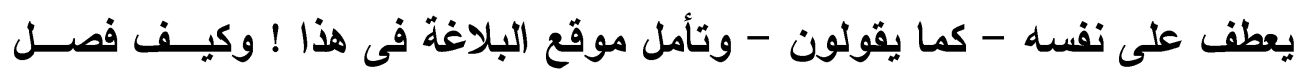

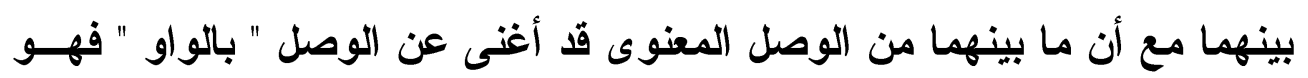

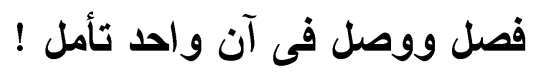


وإن كانت الجملة الثانية أعمق فى الدلالة على طلب الإزالة " والــدنس :

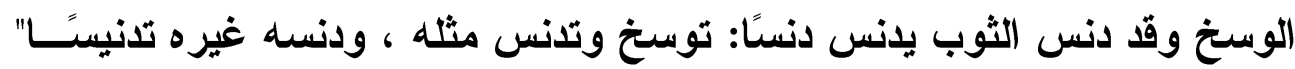

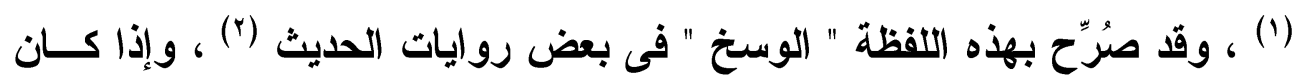

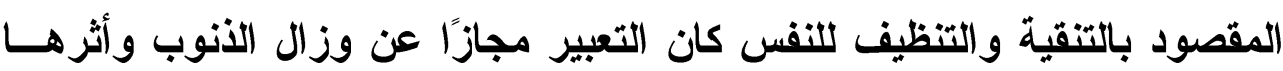

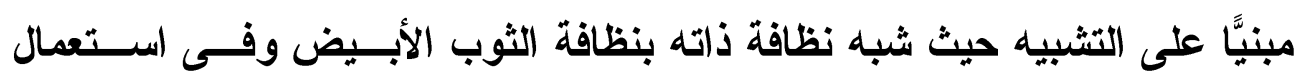

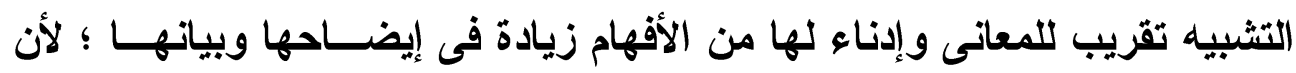

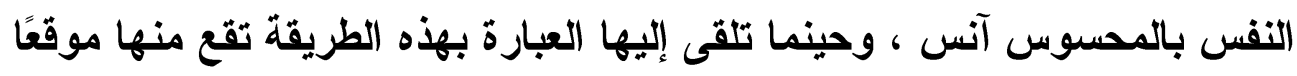

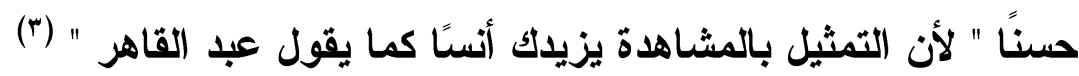

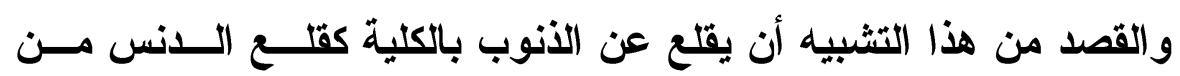

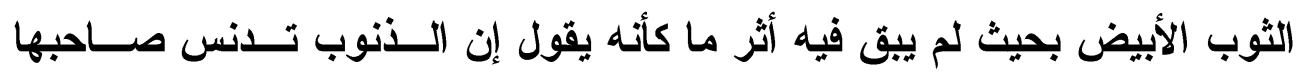

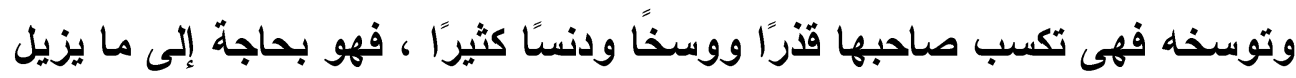

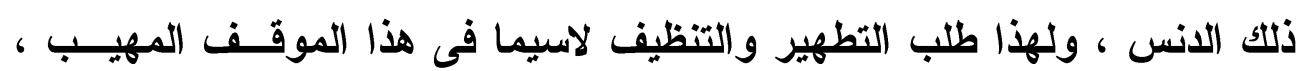

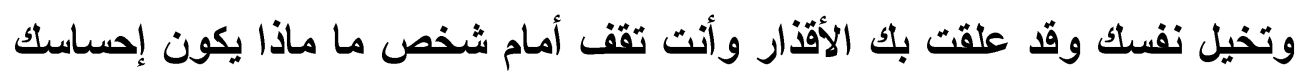

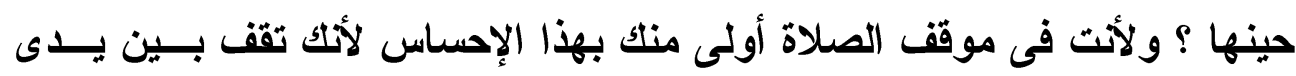

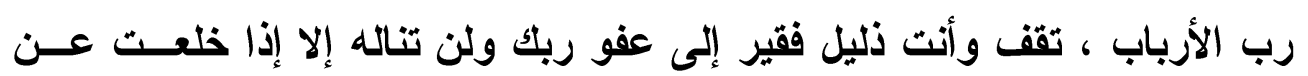

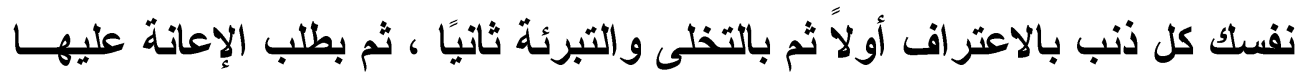

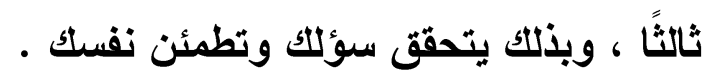

(1) ينظر فى ذلك : الصحاح للجوهرى \& / 9 / ، ، و القاموس المحيط مادة " دنس " ، ولسان

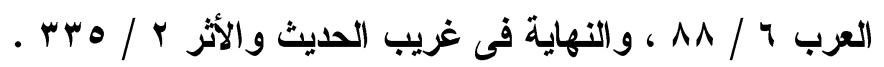

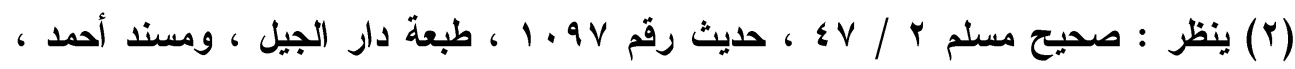

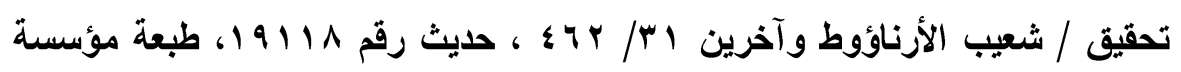

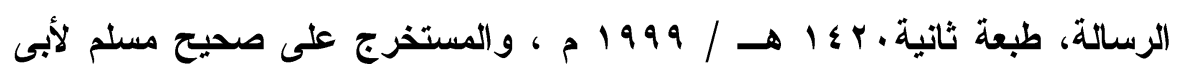

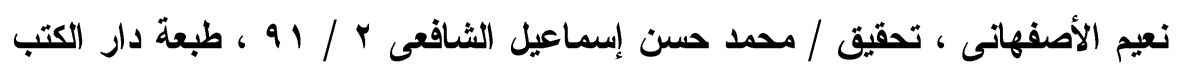

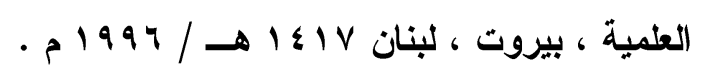

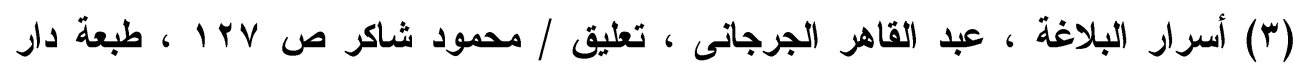

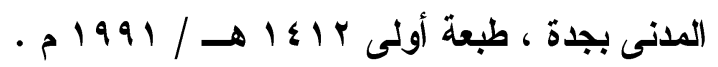


و المد النبوى زاخر وعطاؤه لا يغيض تكتنفه الأسرار من كل جانب وهـو

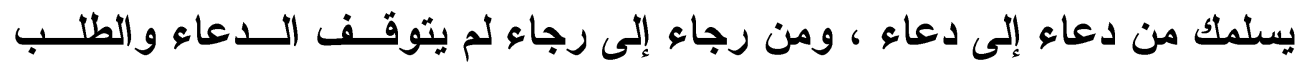

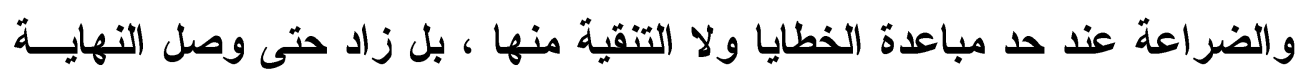

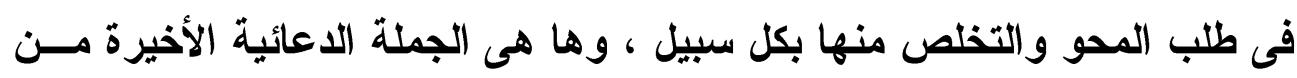
هذا الحديث النبوى تطالعك بهذا : اللهم اغسل خطاياى بالماء والــثلج و البــرد ..

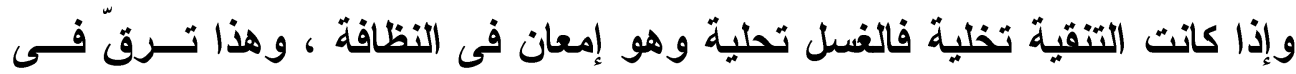

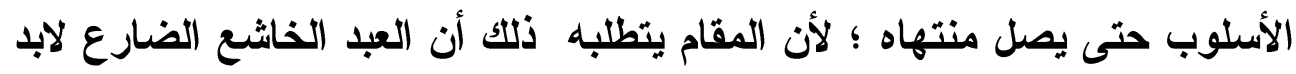

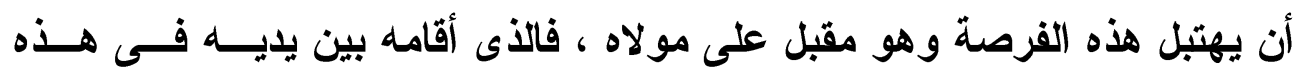

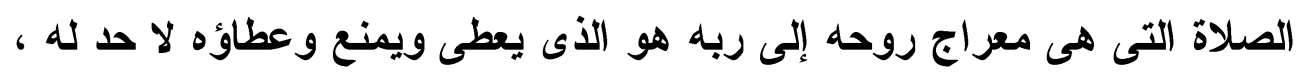

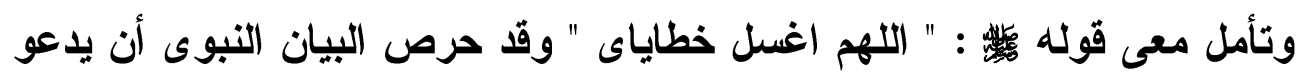

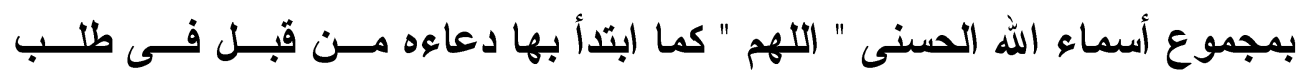

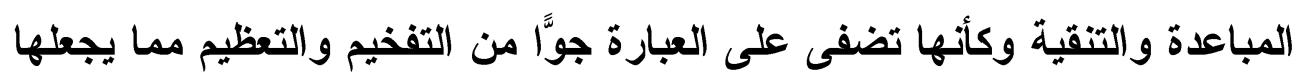

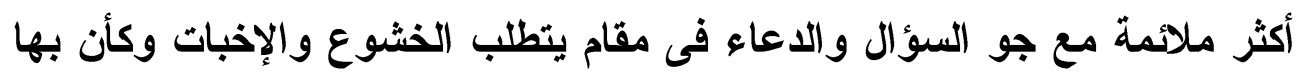

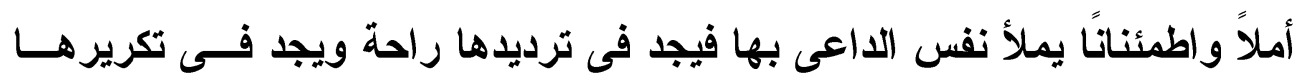

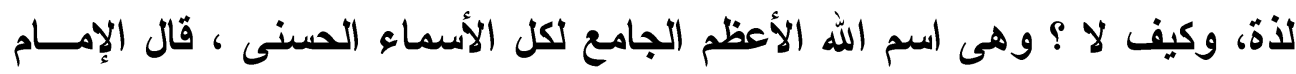

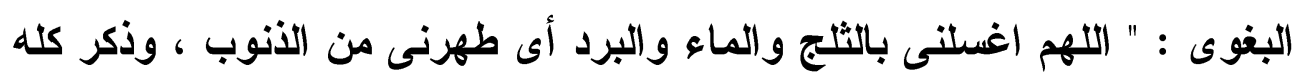

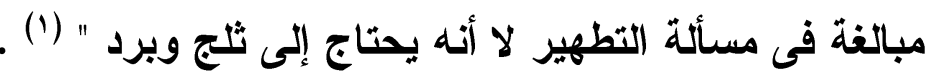

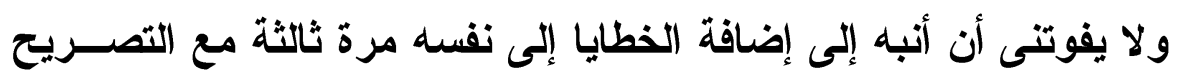

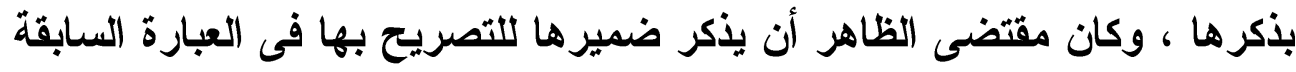

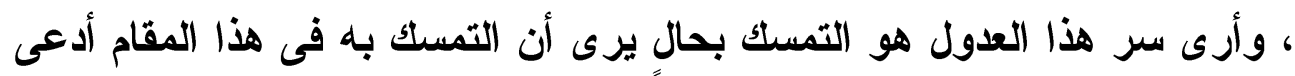

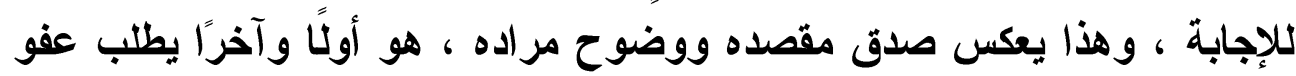

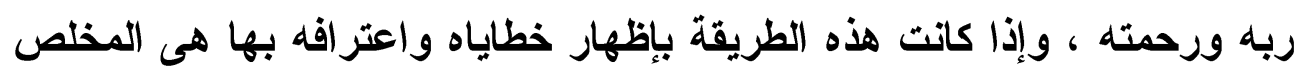

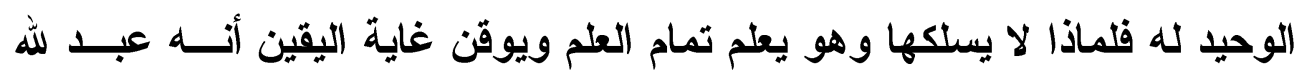

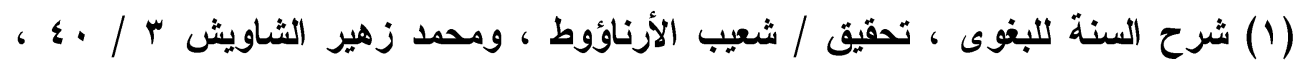

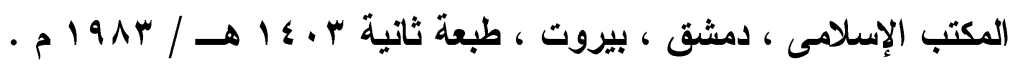


ليس له منجى ولا ملجأ إلا إليه ، وفى ذلك إثشارة إلى تام العبودية و إثـارة أيضَّـا إلى ثقته

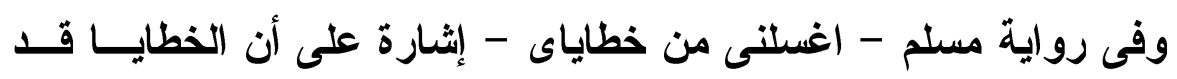

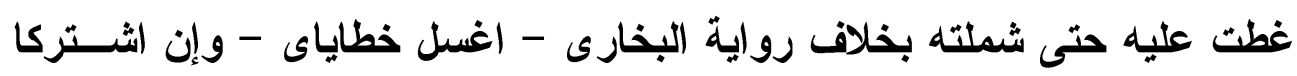

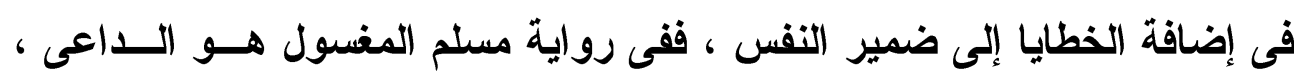

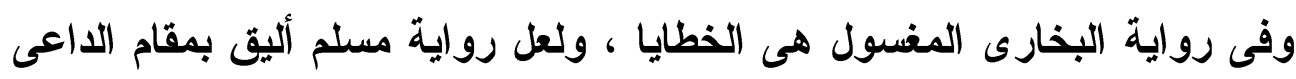

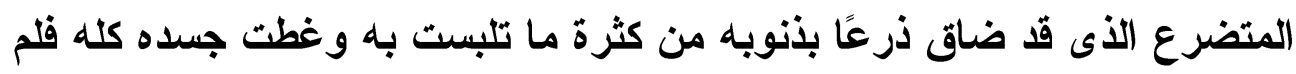

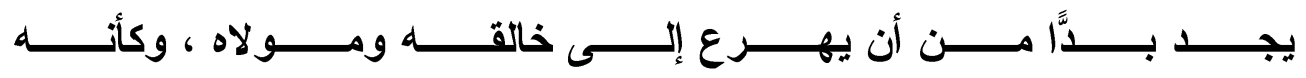

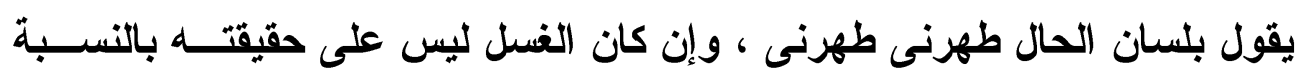

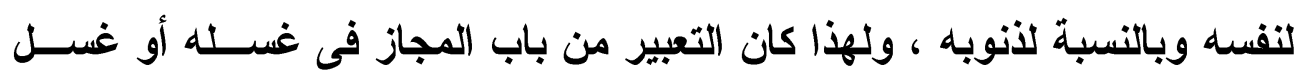

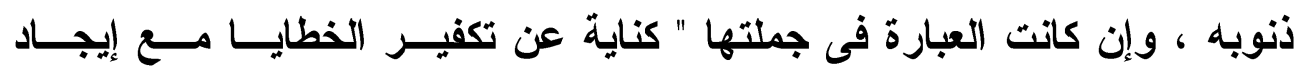

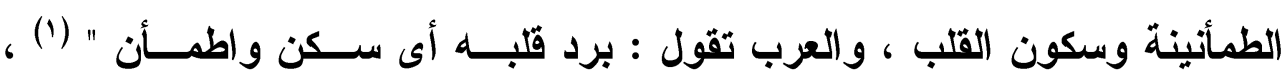

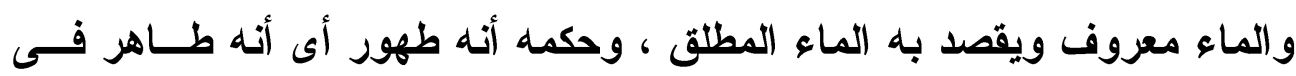

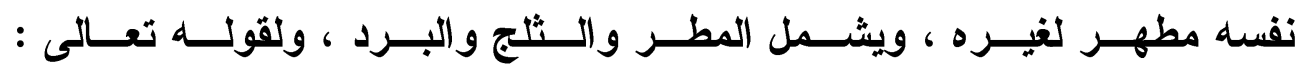

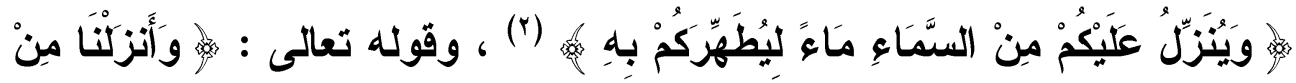

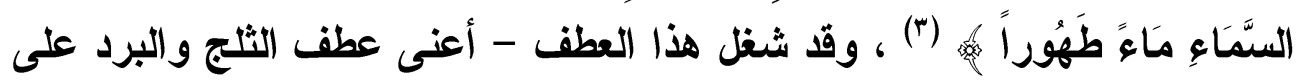

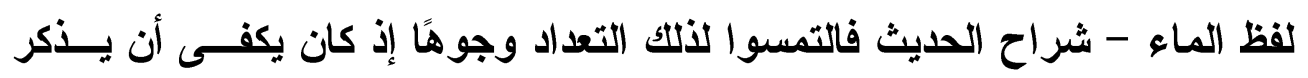

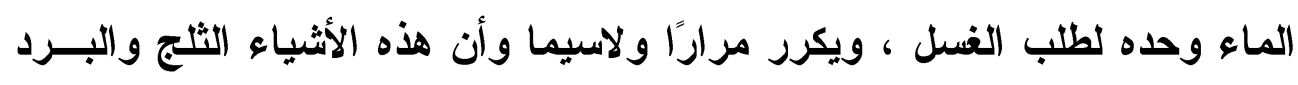

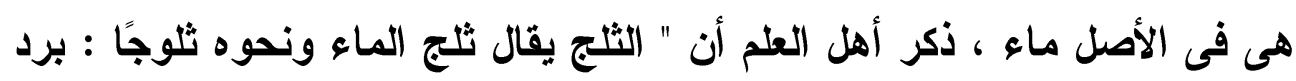

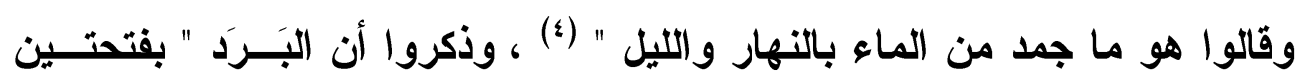

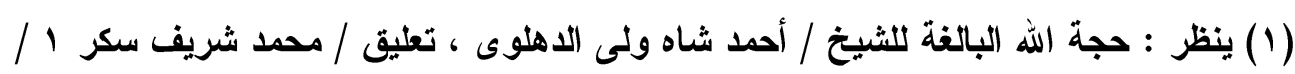

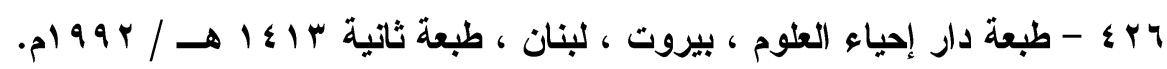

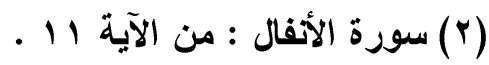

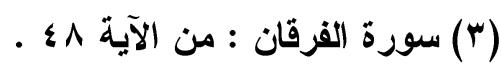

(ع) ينظر فى هذا : المخصص لابن سيده ، تحقيق/ خليل إبراهيم جفال ؟ / ه بـ ، طبعة دار 
شىع ينزل من السحاب يشبه الحصى ويسمى حب الغمام وحب المزن وأنه كذلك

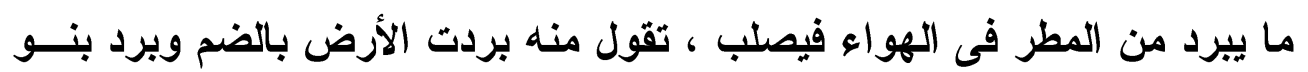

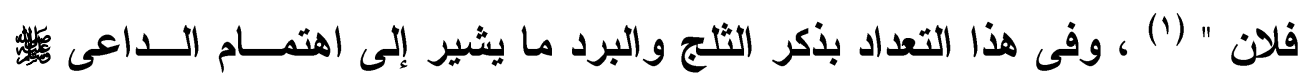

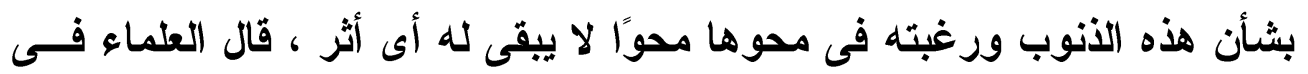

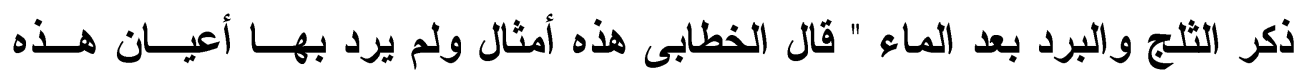

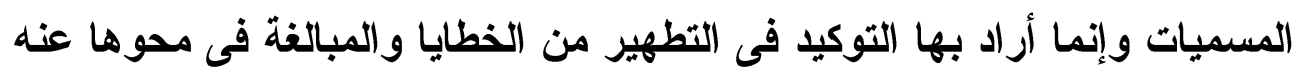

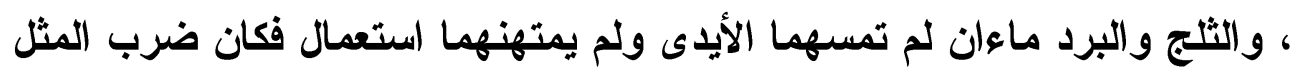

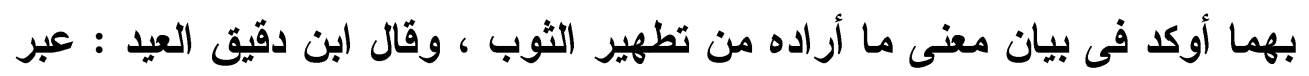

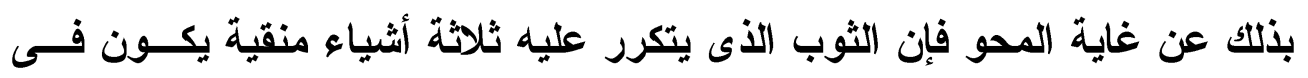

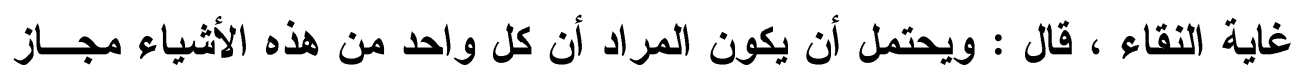

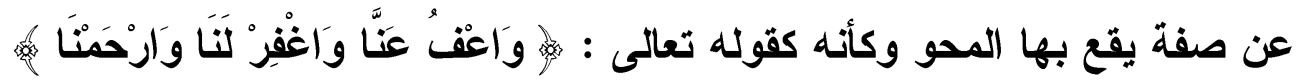

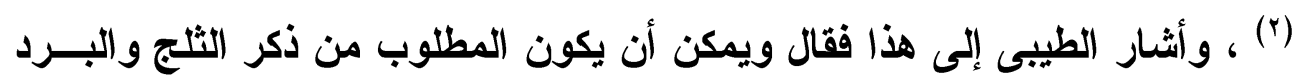

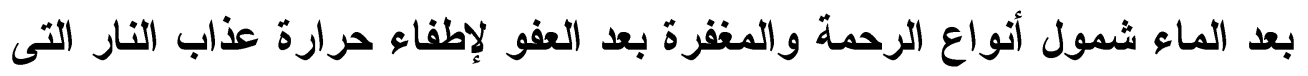

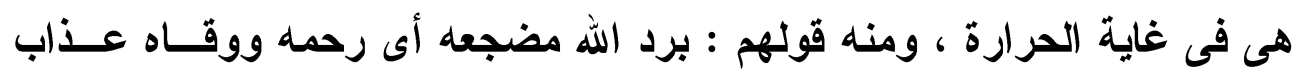

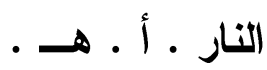

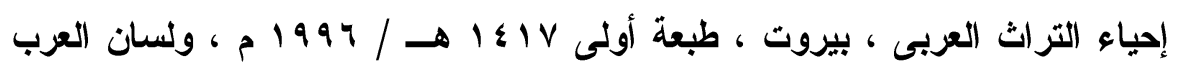

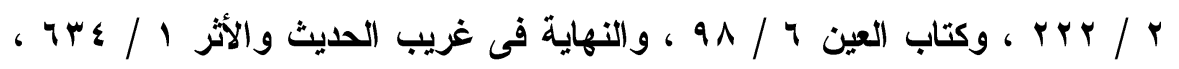

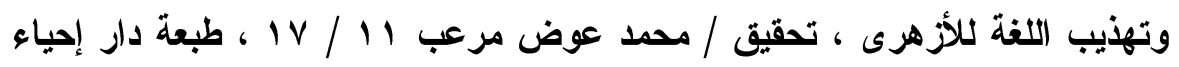

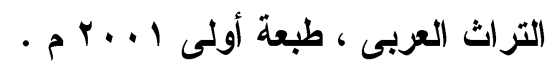

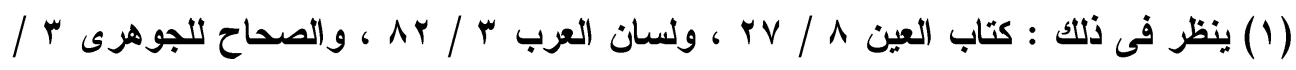

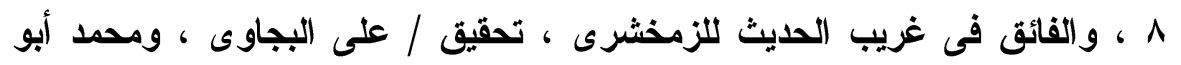

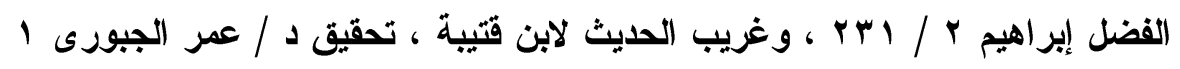

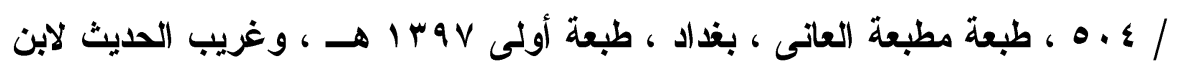

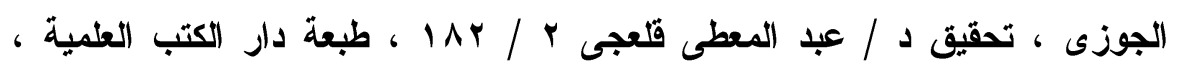

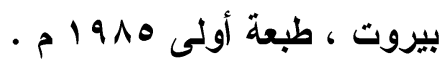

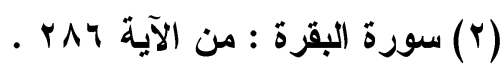




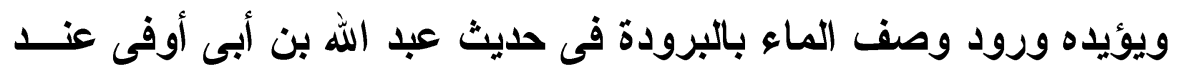

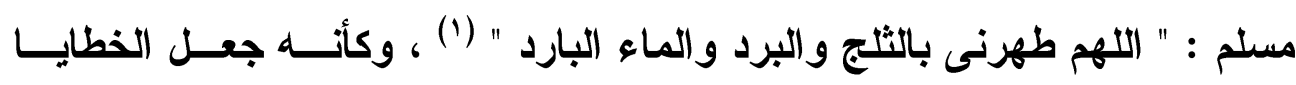

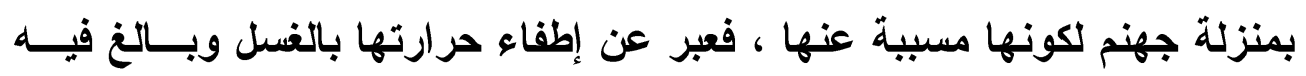

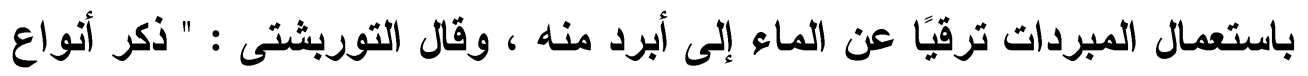

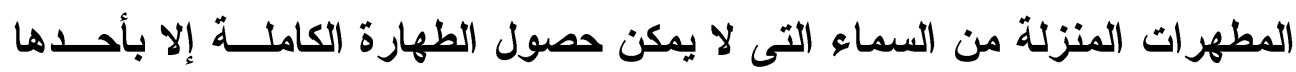
بيانًا لأنواع المغفرة التى لا تخلص من الأنوب إلا بها أى طهرنى بأنواع مغفرتك التك

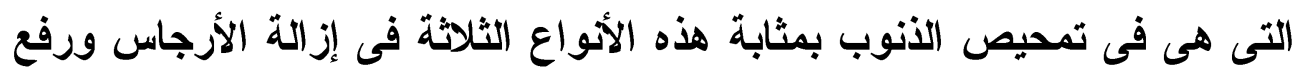

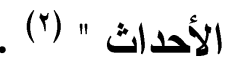

وكلام الطيبى السابق الأى أشتار فيه إلى أن ذكر الثاج والبرد بعد المــاء

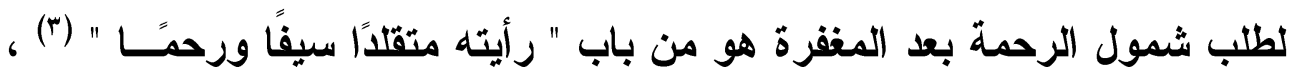
وزاد الكرمانى أنه " يحتمل أن يكون فحى الاعوات الثلاث إثـارة إلى الأزمنة الثلاثة فالمباعدة للمستقبل والتثقية للحال والغسل للماضى وكأن تقديم المستقبل للاهتمام بلفع ما سيأتى قبل رفع ما حصل " (؛) .

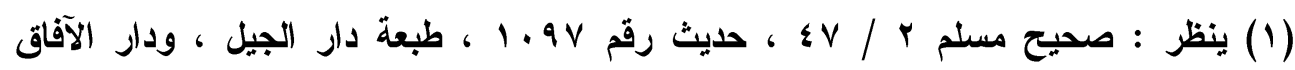

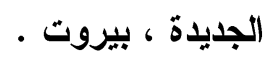

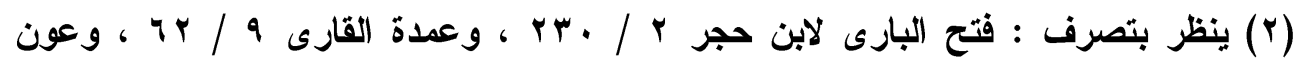

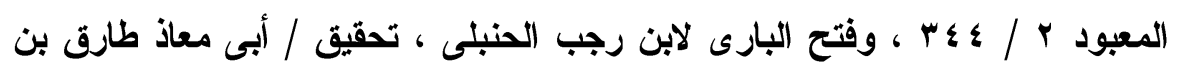

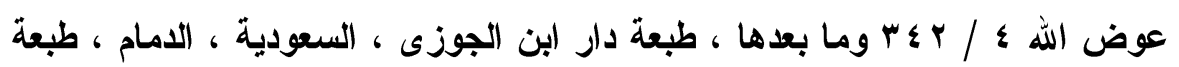

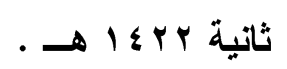

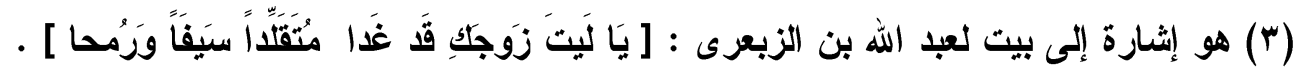

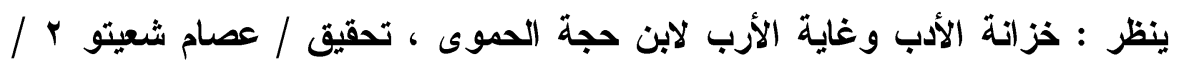

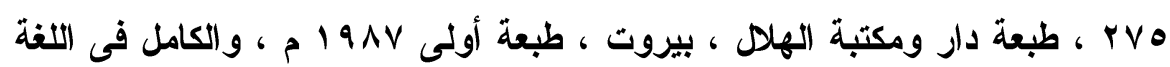

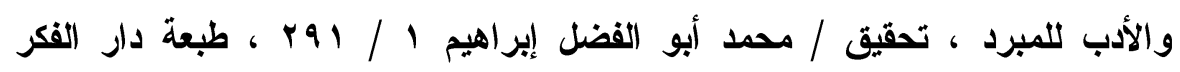

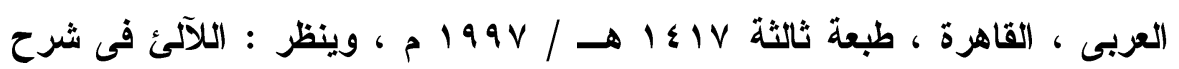

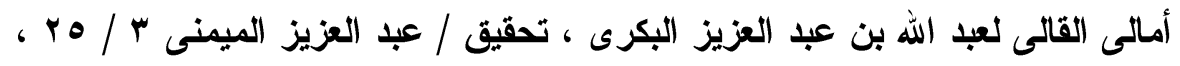

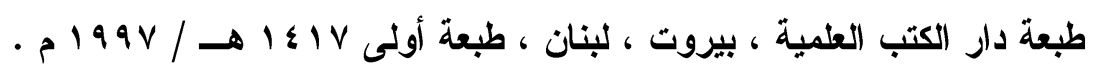

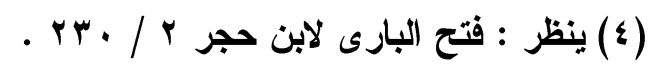


وأقول كل هذه الاحتمالات يحتملها ظاهر الحديث ، وكلها تدل علــى دقـــة اختيار الألفاظ النبوية النى تناسب المقام والتى تتسع وتمتد حتى تفى باحتياجـات التهات

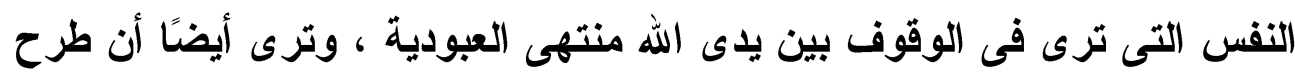

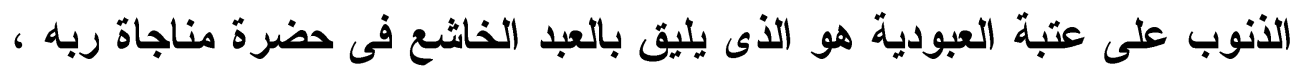

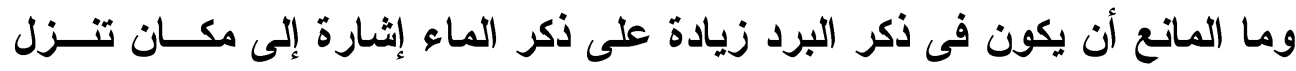

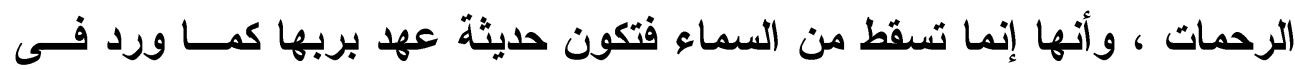

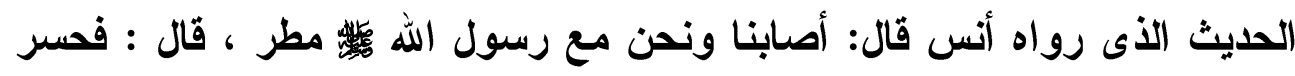
رسول الله

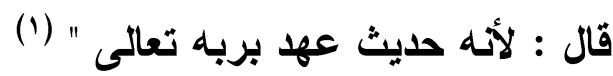

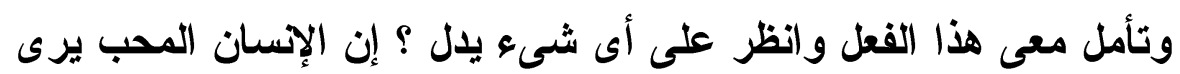

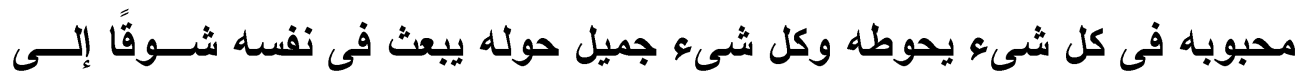

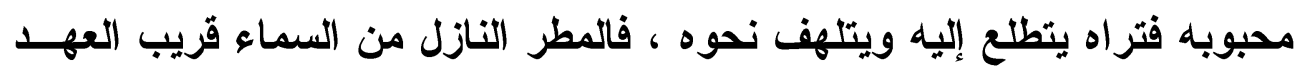

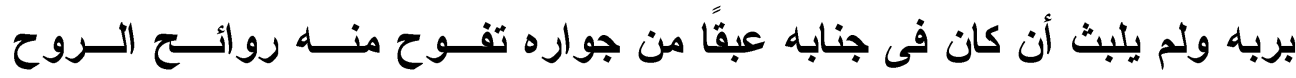

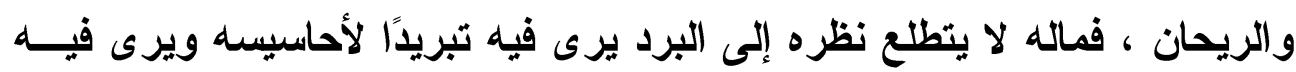

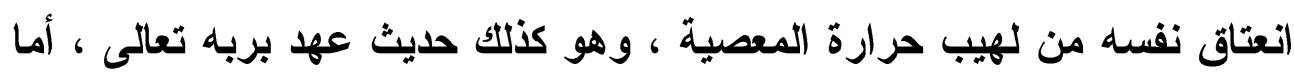

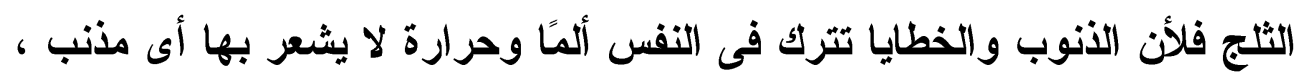

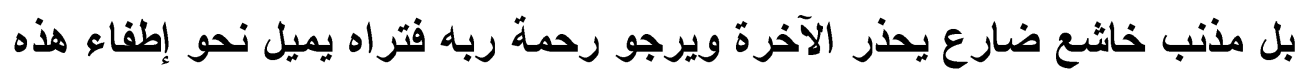

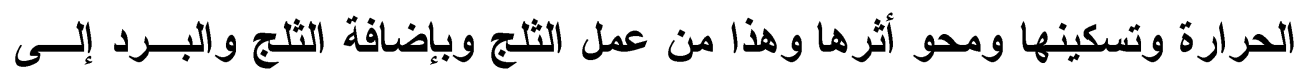

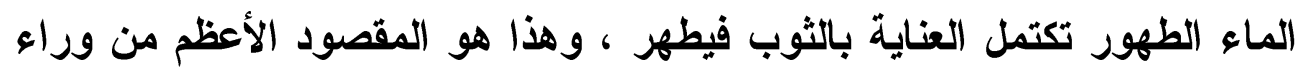

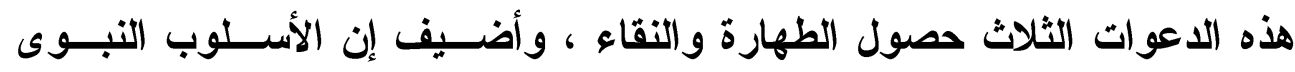

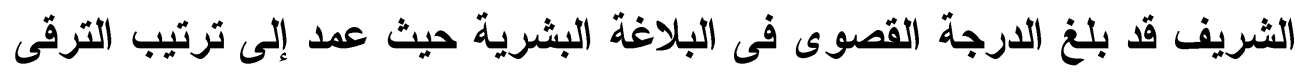

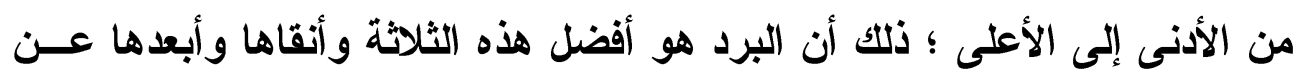

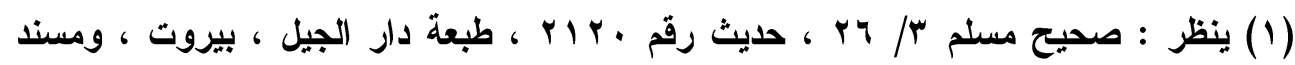

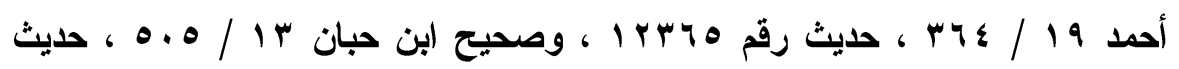




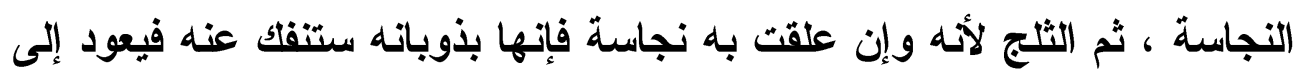

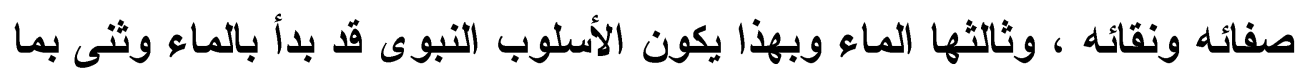

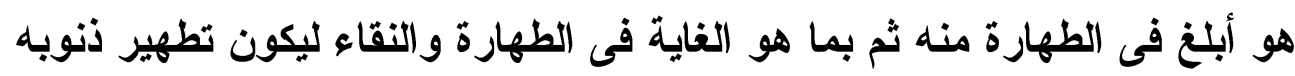

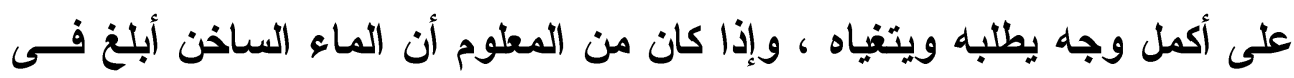

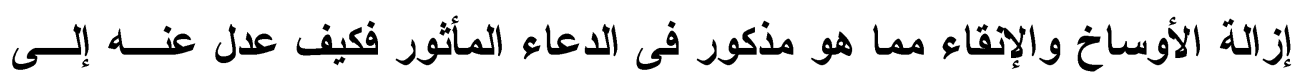

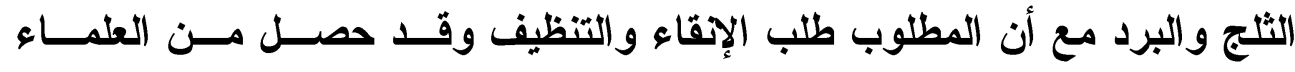

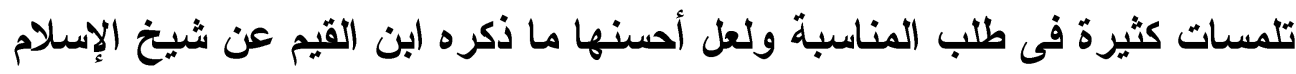

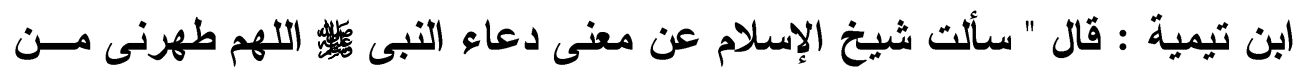

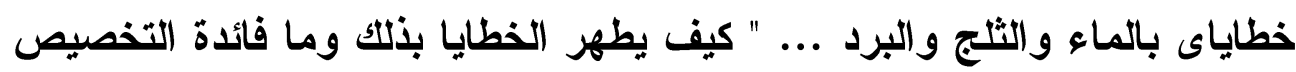

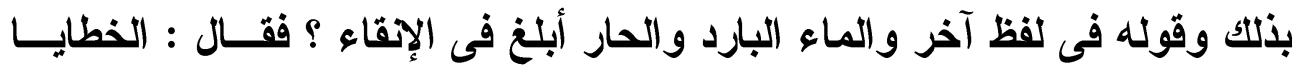

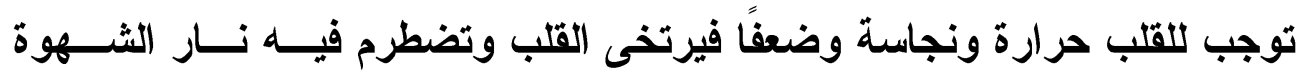

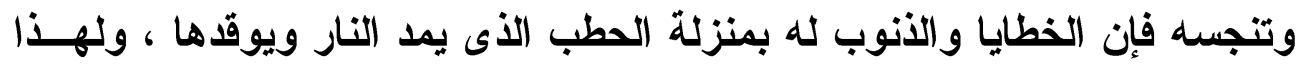

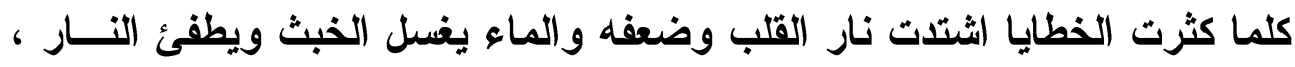

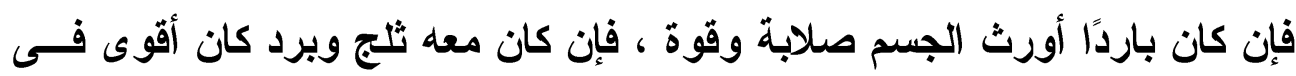

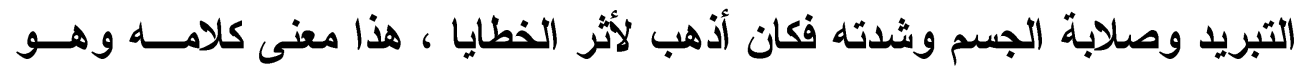

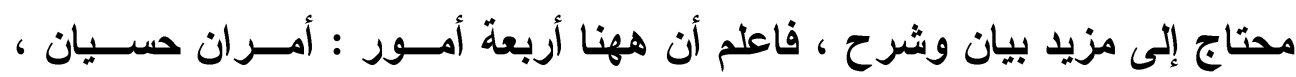

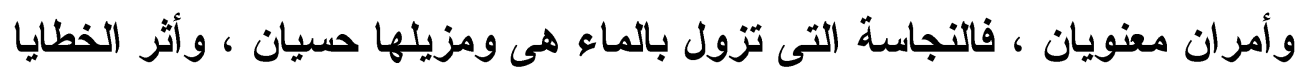

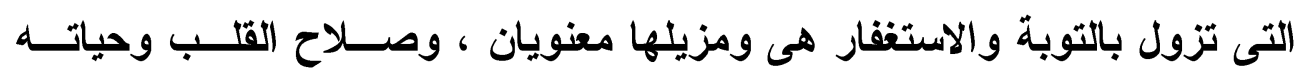

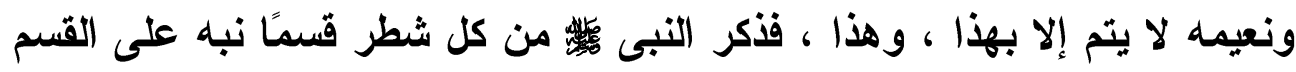

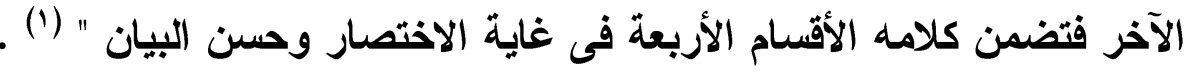

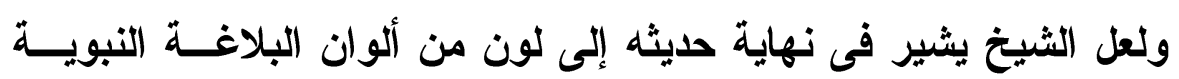

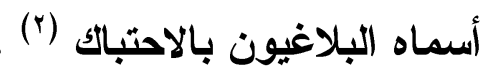

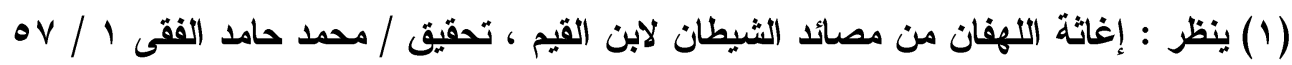

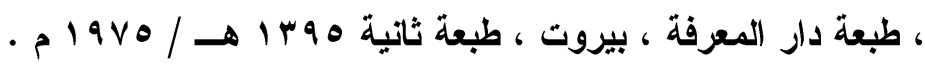

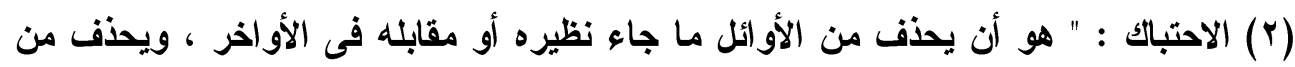


وبعد هذه التطوافة الرائقة فى بستان التضرع والدعاء النبوى التى تجلت

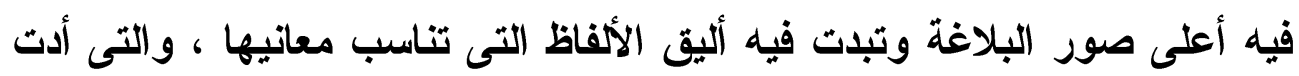

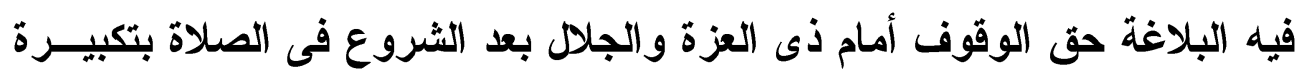

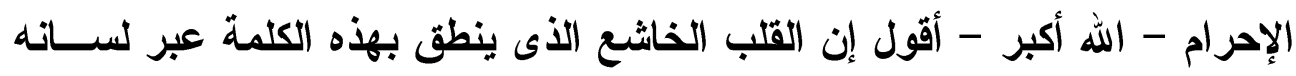

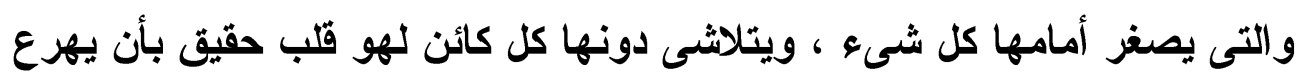

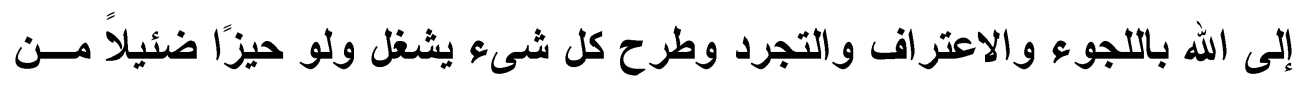

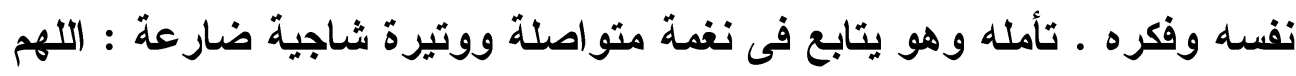

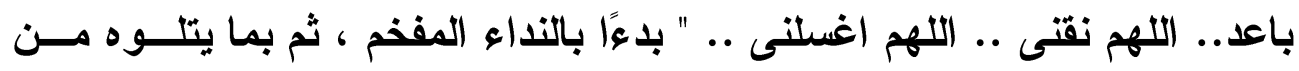

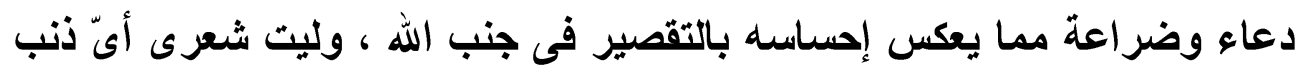

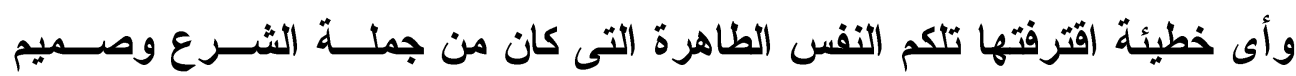

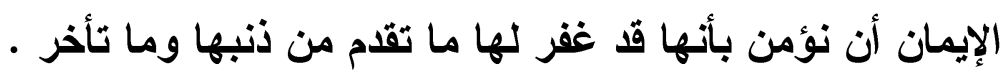

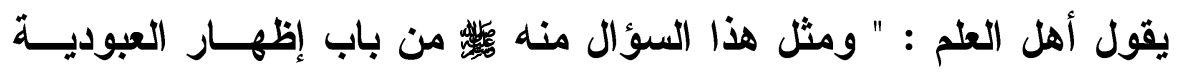

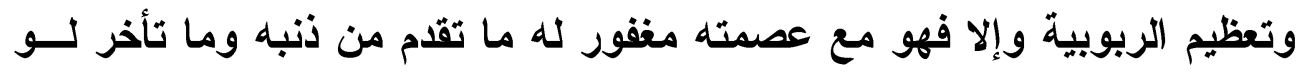

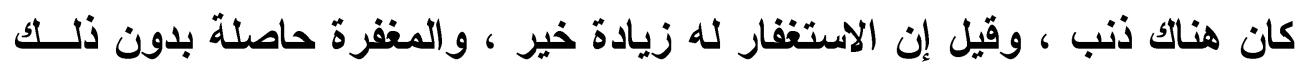

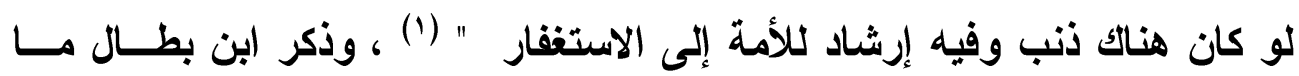

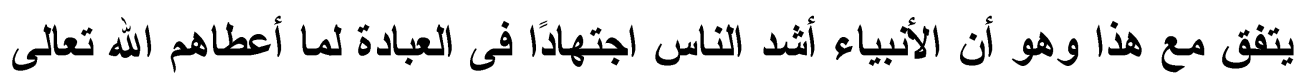

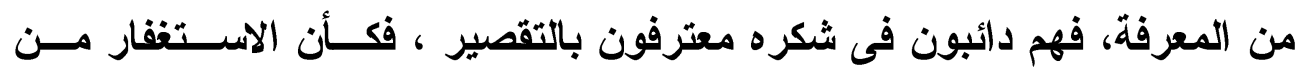

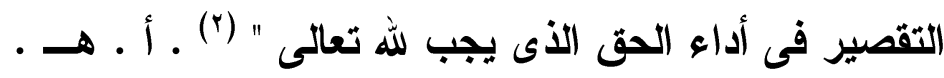

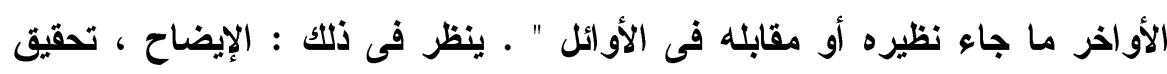

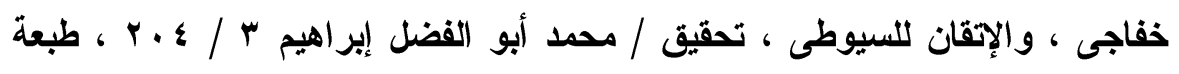

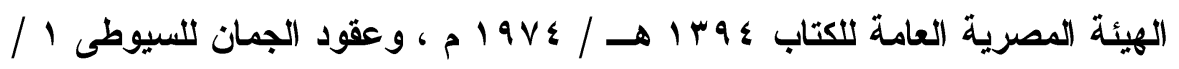

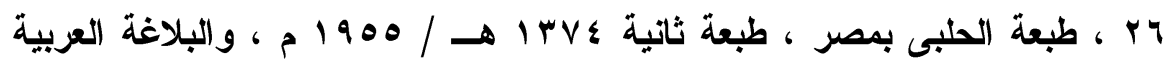

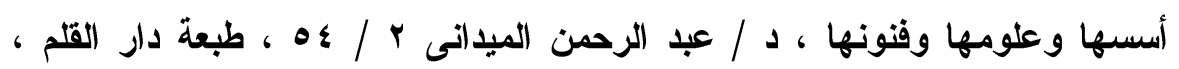

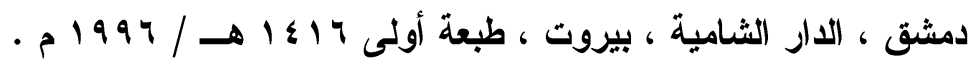

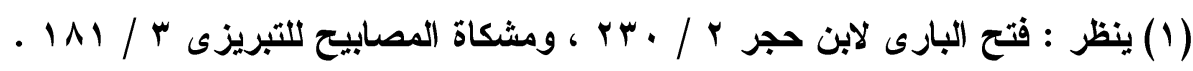

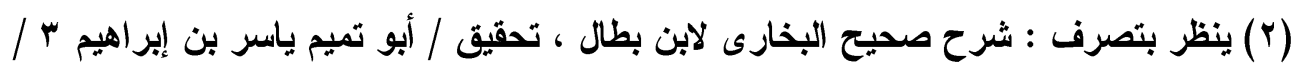


كلامه - رحمه الله - هذا ... وقد وردث أحاديث صــيحة فـى دعــاء

الاستقتاح عن النبى

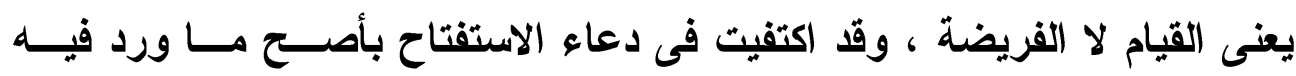

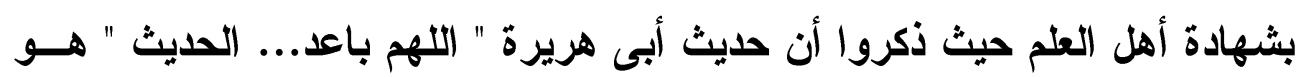

أصح الأحاديث الواردة فى الاستفتاح (') .

. 11 ، طبعة مكتبة الرشد ، السعودية ، الرياض ، طبعة ثانية بrع 1 هـ / $\cdot r$. r r

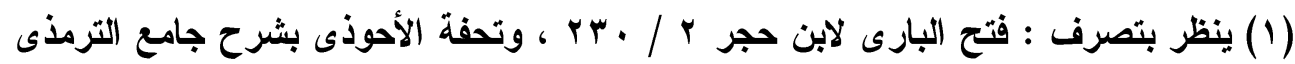

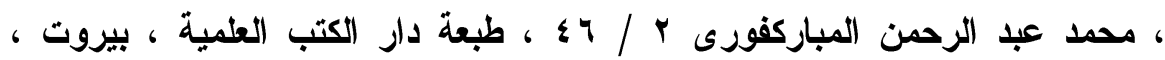

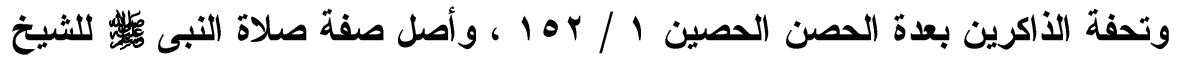

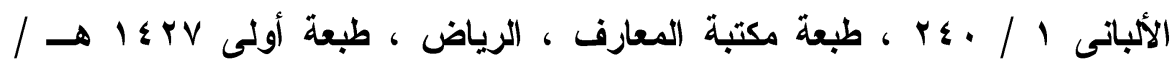

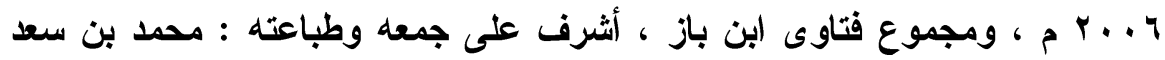

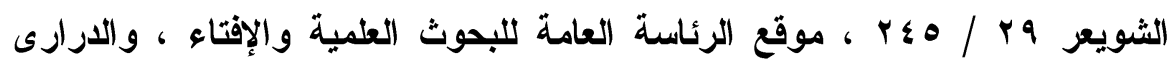

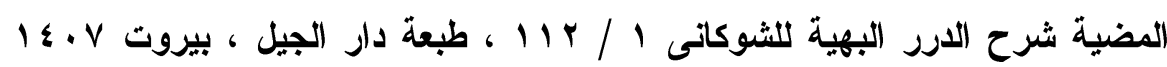

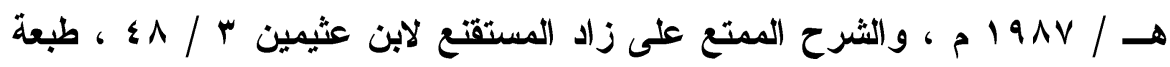

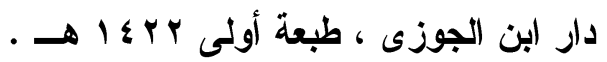




\section{الإبمث الثانى}

\section{ما يقال من الدعاء فى الركوع}

الدعاء الأول : المز

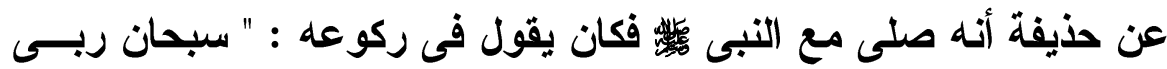
العظيم ، وفى سجوده: سبحان ربى الأعلى ، وما مر بآية رحمة إلا وقف عنس العـدها

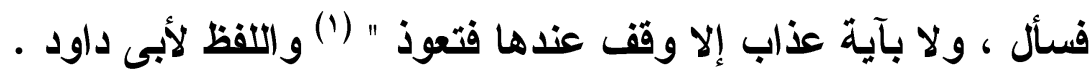

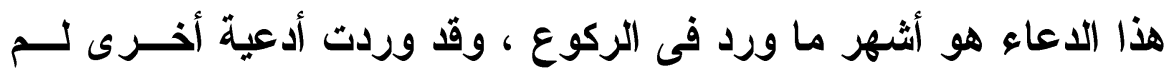

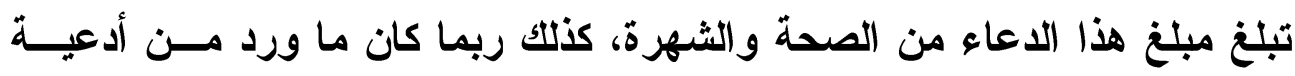

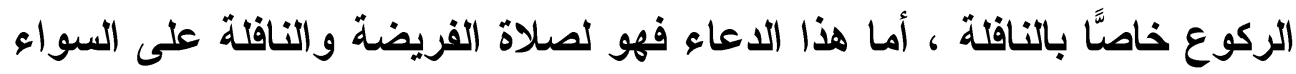

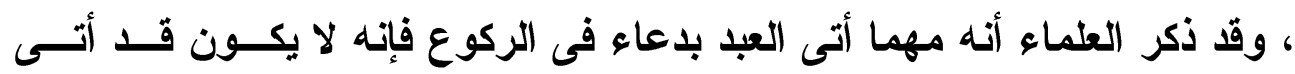

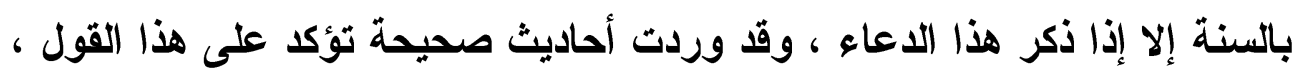

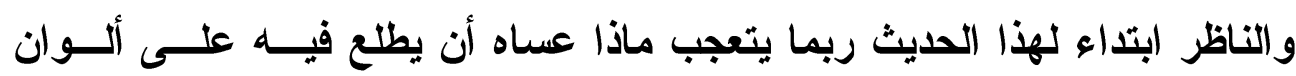

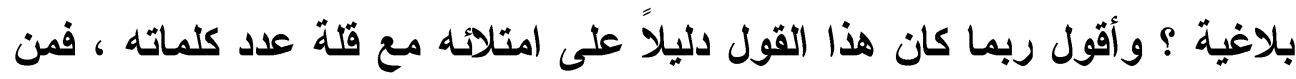
شدة الظهور الذفاء فأقول وبالله التوفيق :

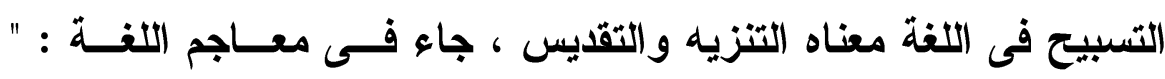

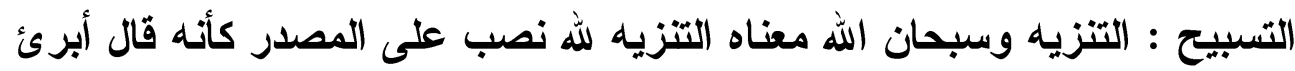

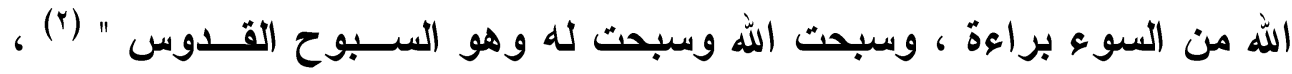

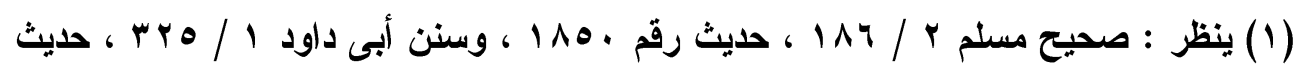

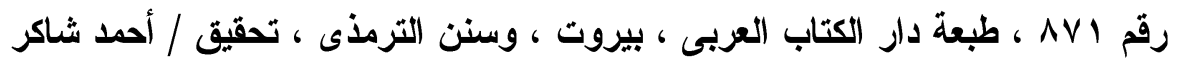

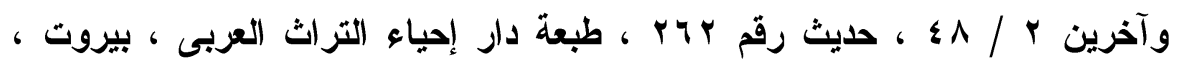

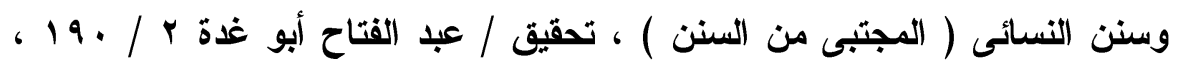

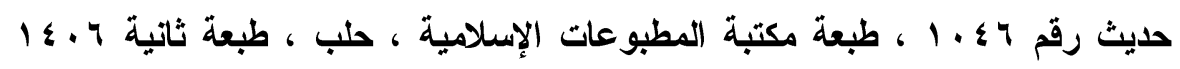

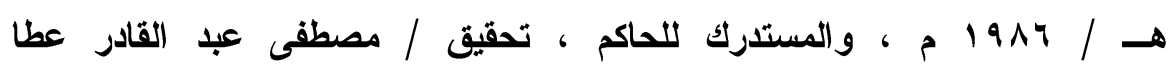

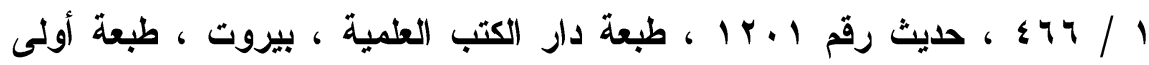

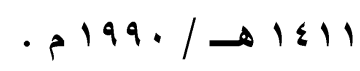

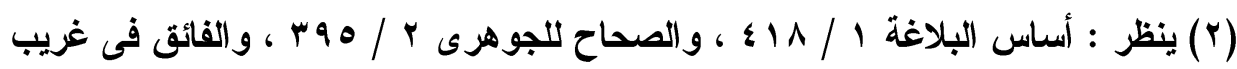




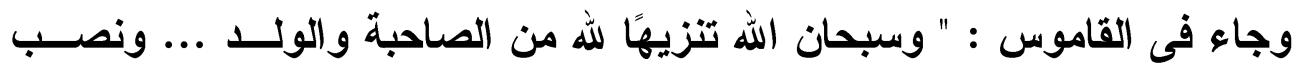

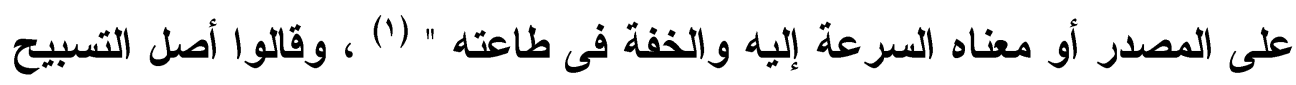

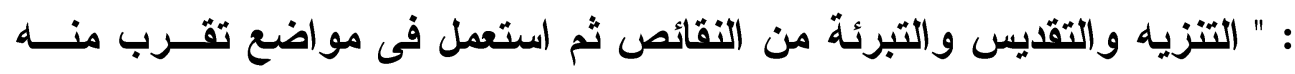

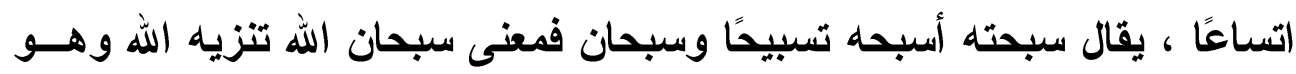

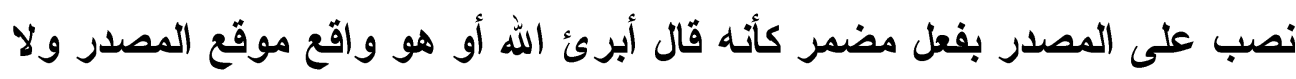

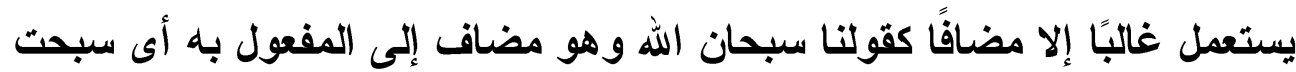

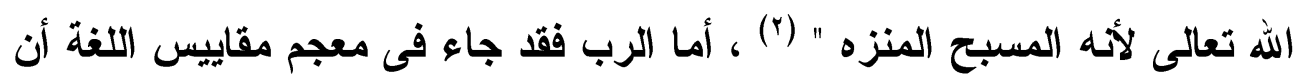

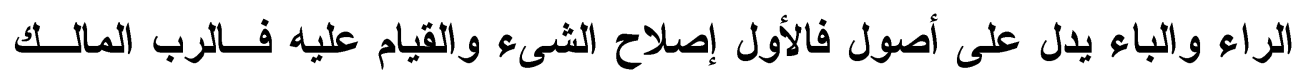

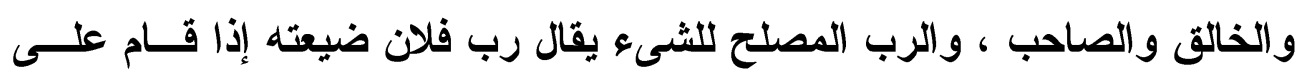

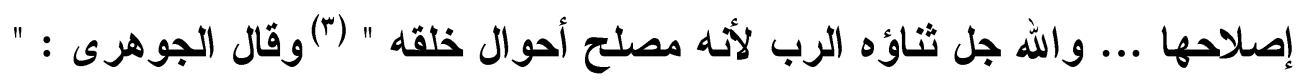

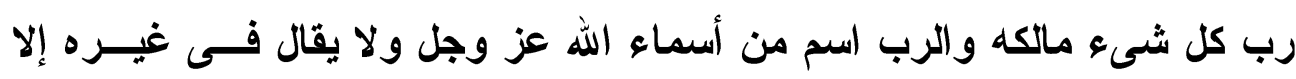

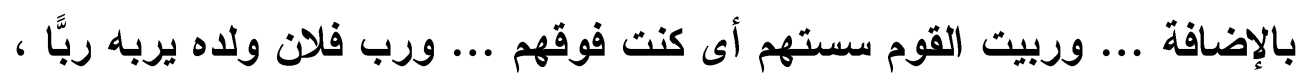

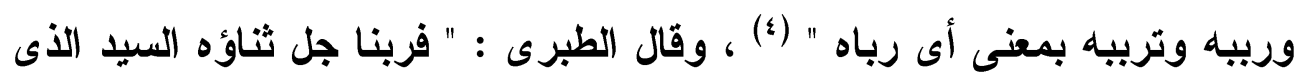

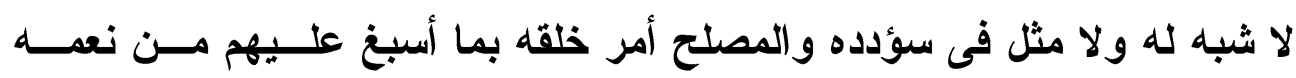

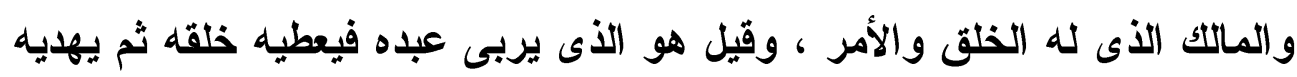

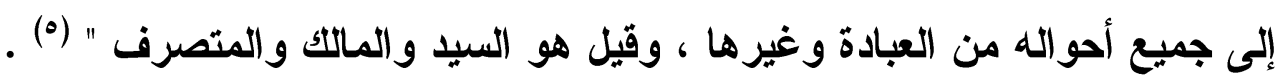

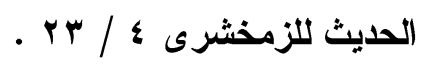

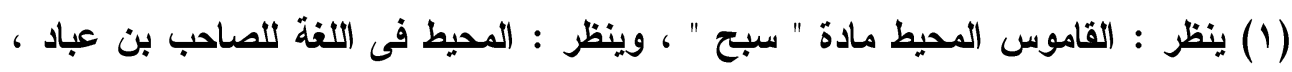

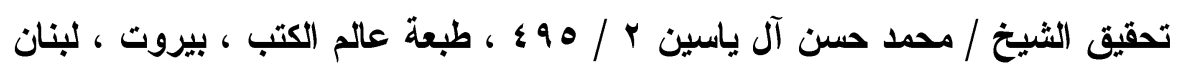

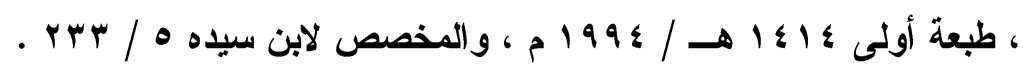

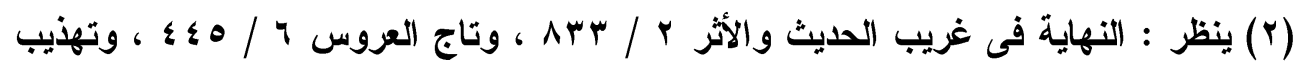

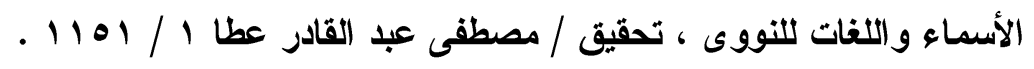

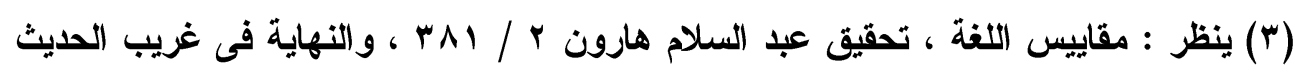

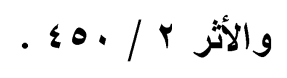

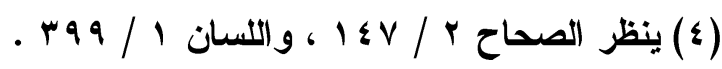

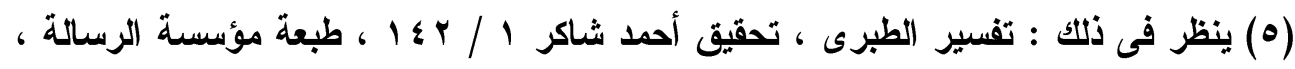




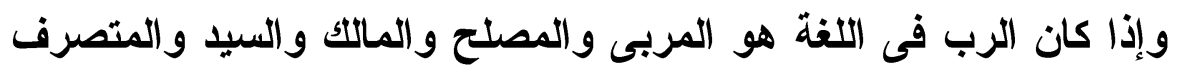

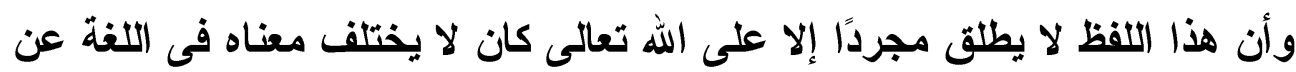

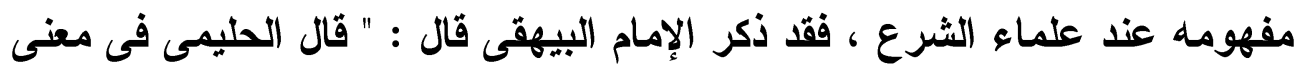

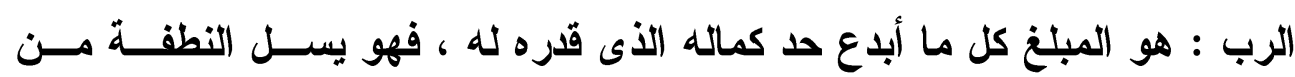

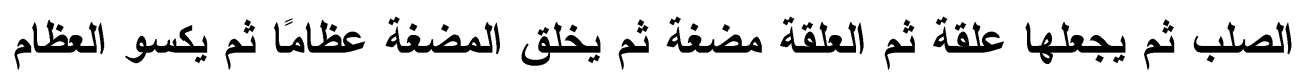

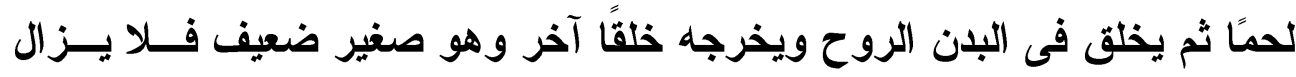

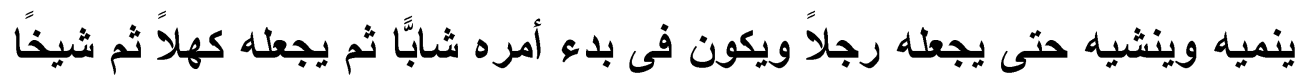

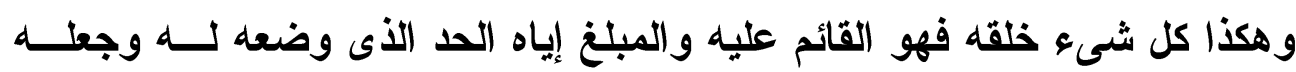

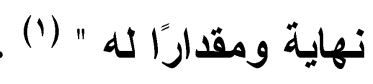

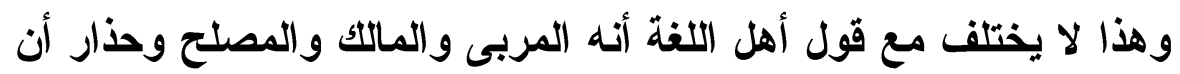

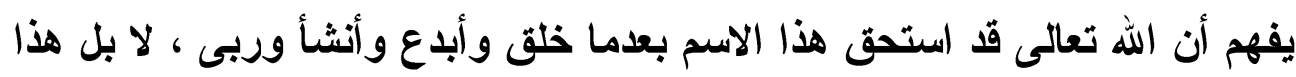

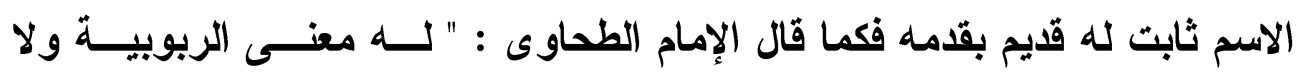

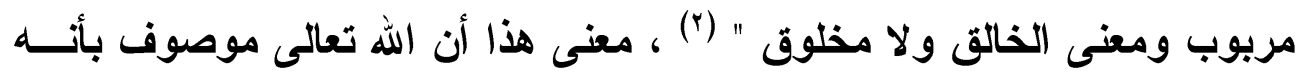

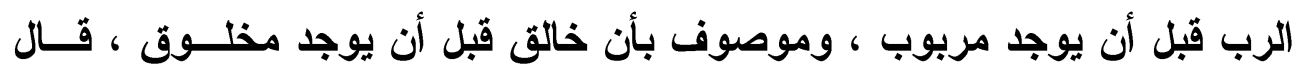

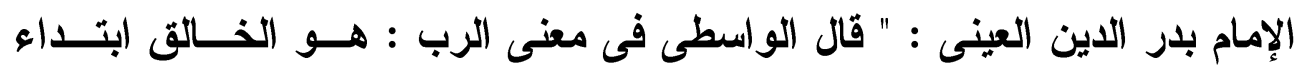

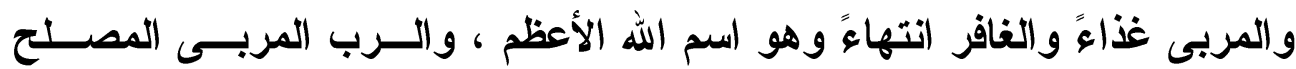

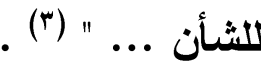

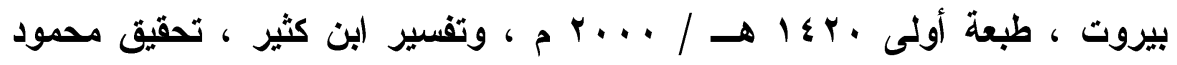

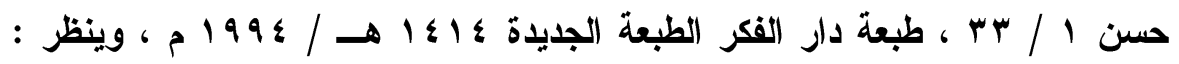

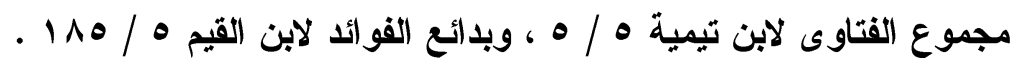

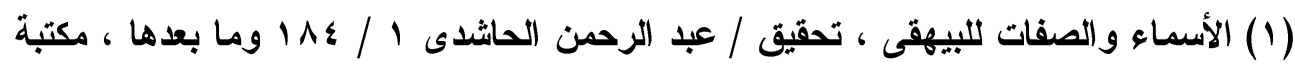

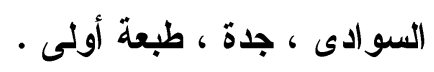

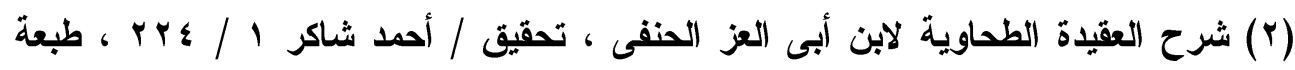

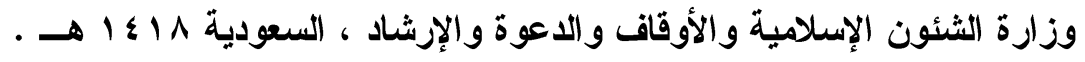

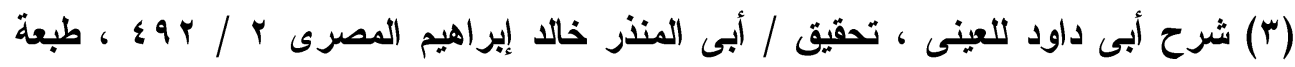

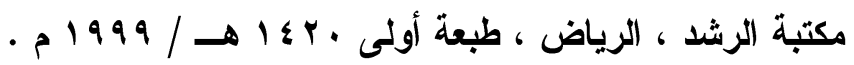


وقوله " العظيم " هو فى اللغة صفة مشبهة لمن اتصف بالعظمــة فعلــهـ

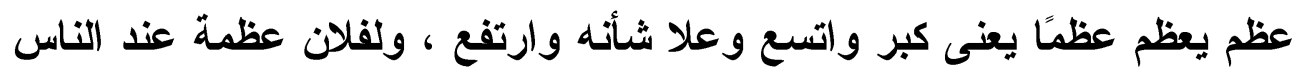

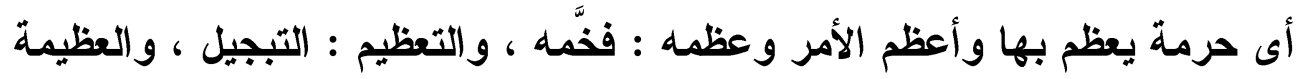

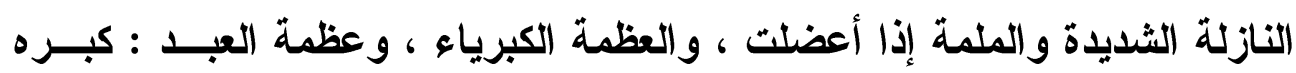

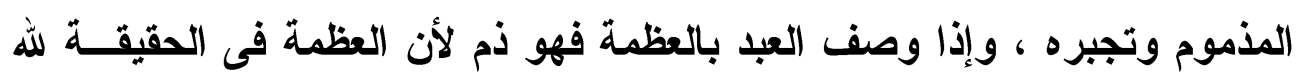

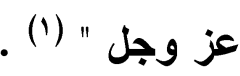

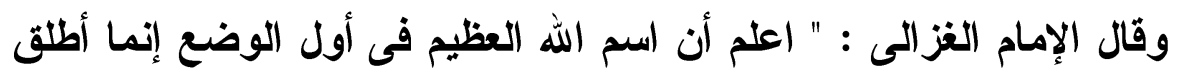

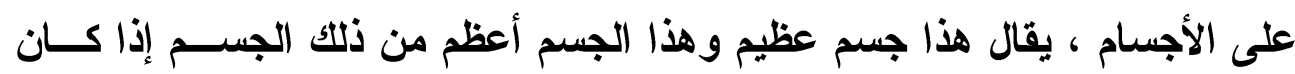

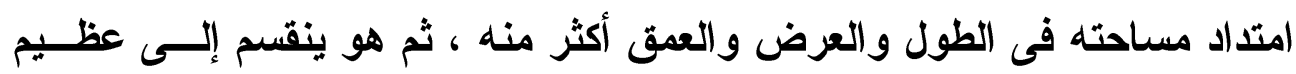

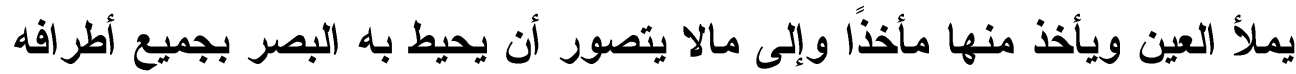

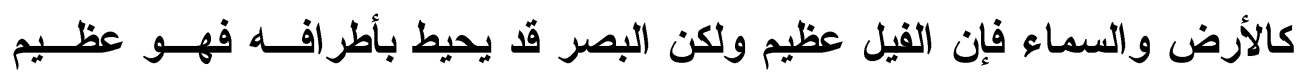

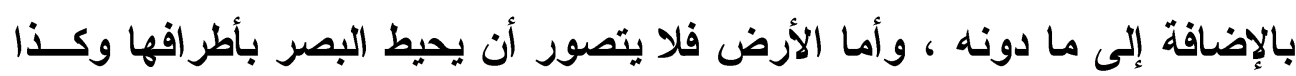

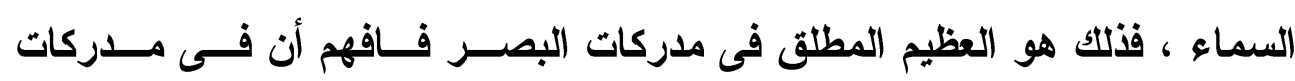

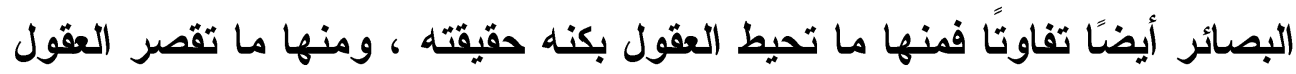

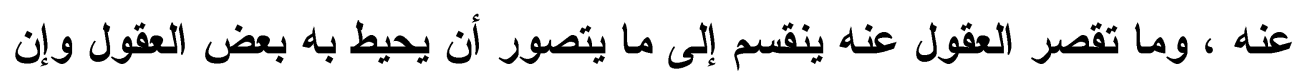

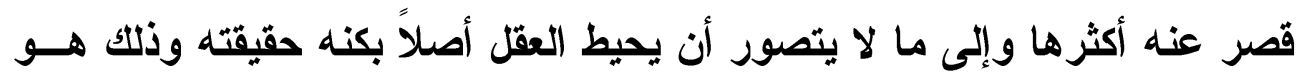

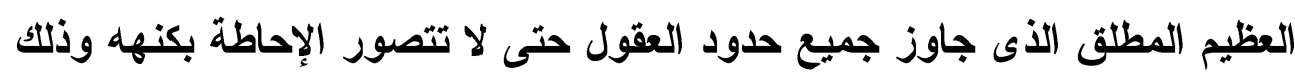

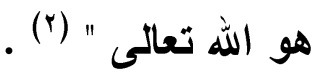

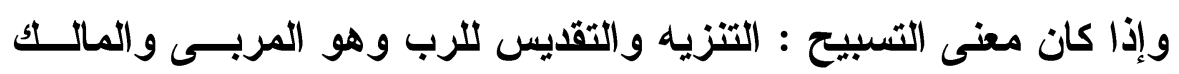

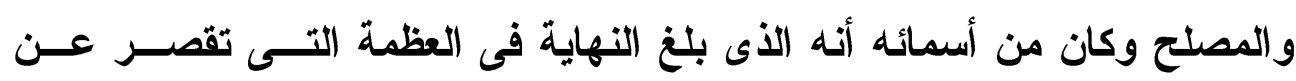

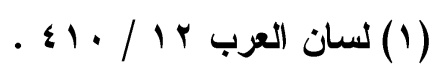

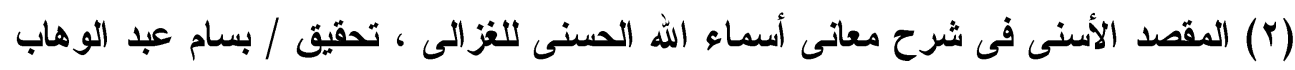

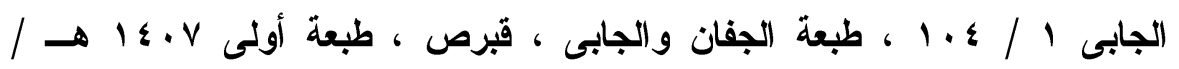

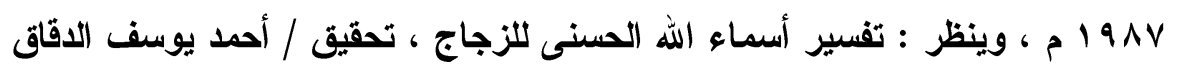

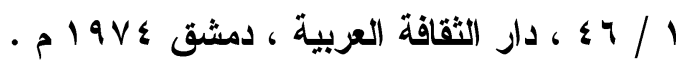




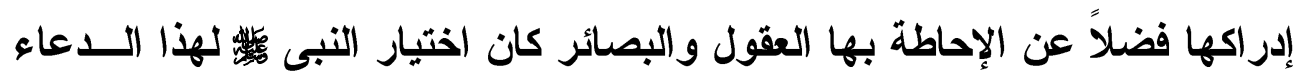

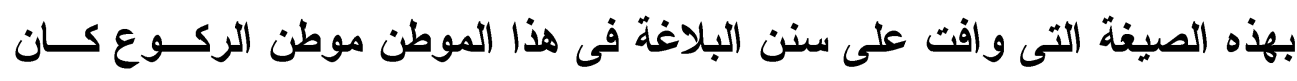

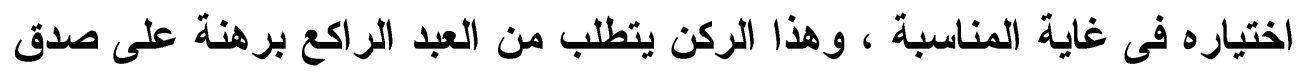

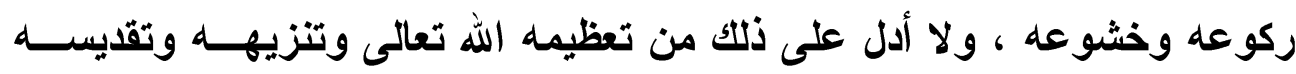

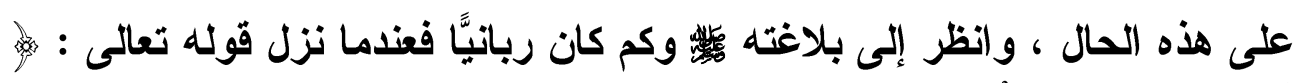

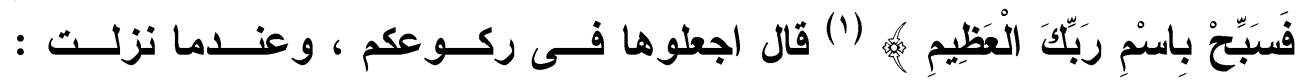

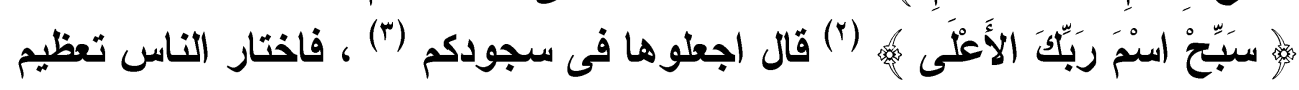

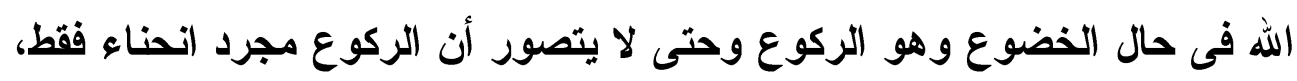

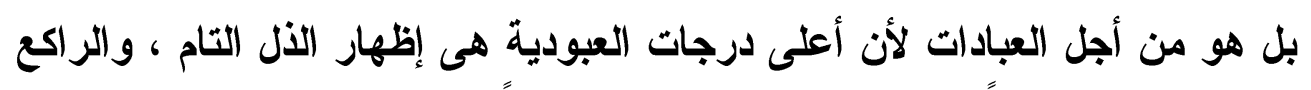

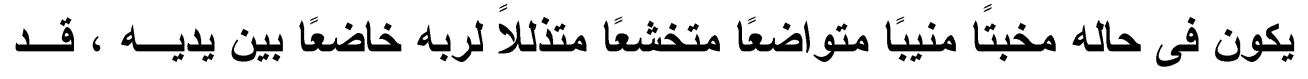

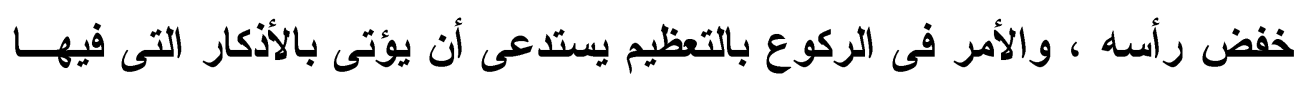

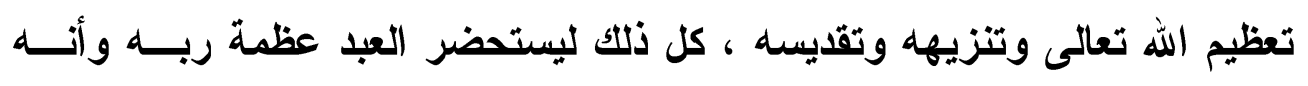

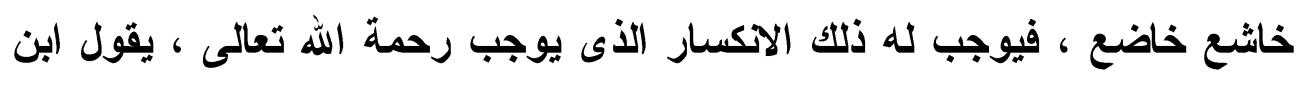

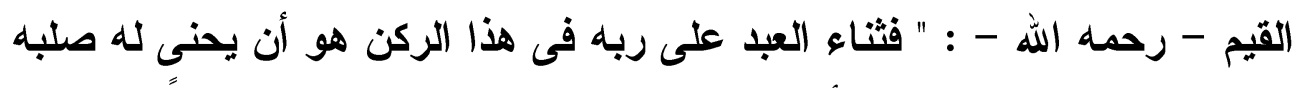

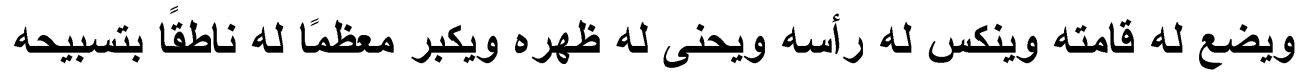

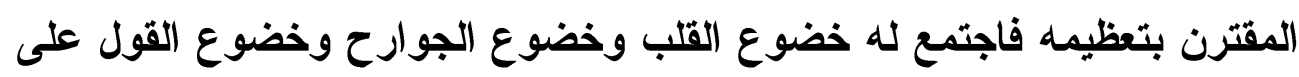

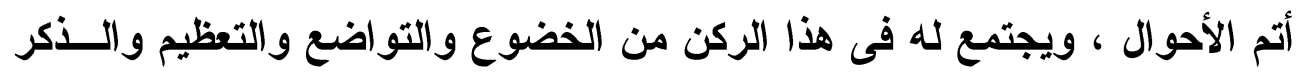

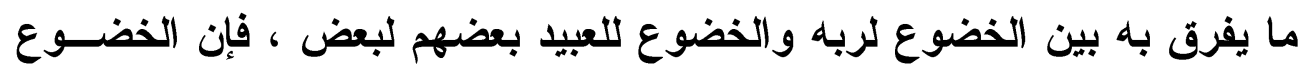

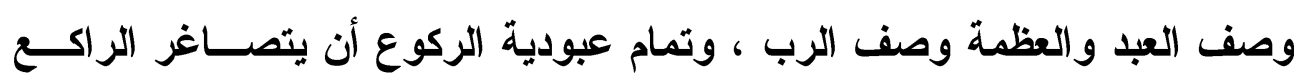

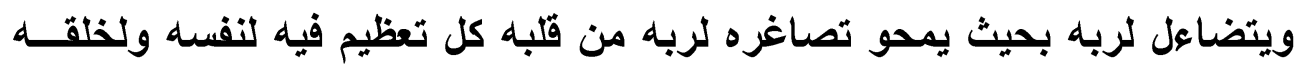

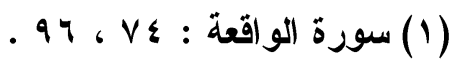

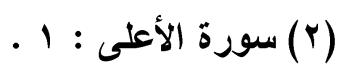

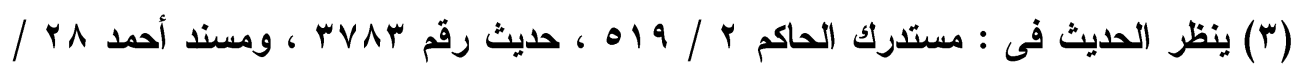

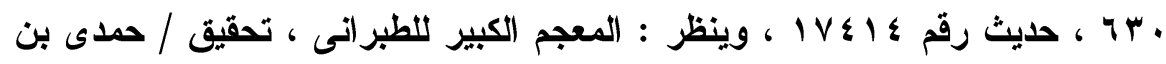

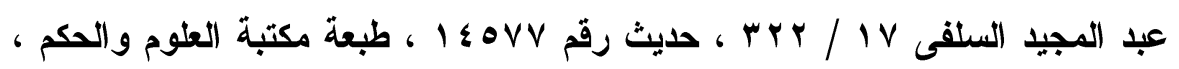

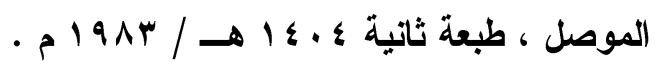


ويثبت مكانه تعظيم ربه وحده لا شريك له إذا عظم القلب الرب خرج تعظيم الخلق

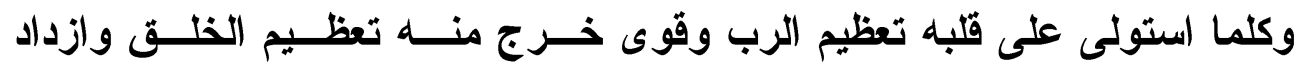

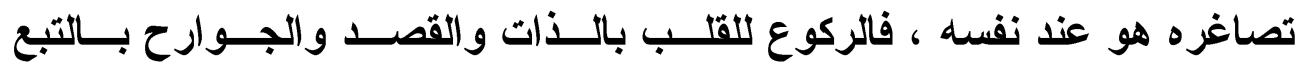

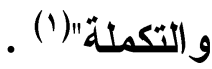

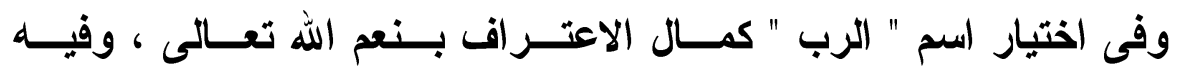

استعطاف، وفى إضافة هذا الاسم الجليل إلى ضمير النفس من كل راكع ولاســيما

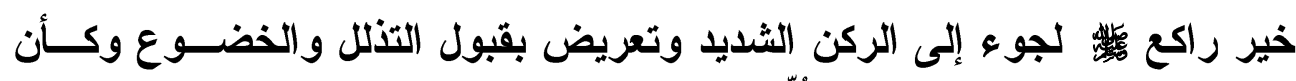

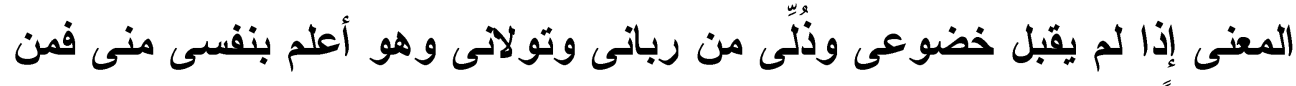
يكون إذاً ؟ .

وفى ذكر " العظيم " إعلان من العبد أنه مهما تضرع وتخضع ومهما بذل

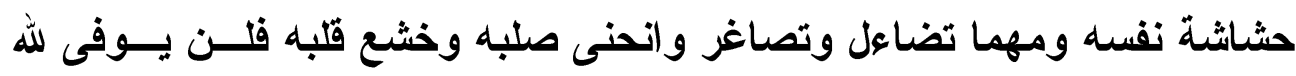

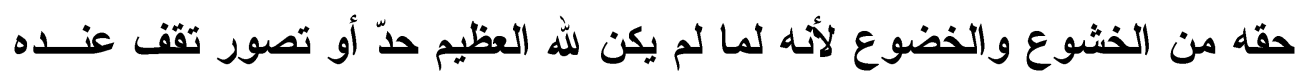

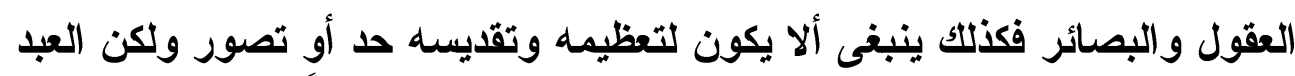

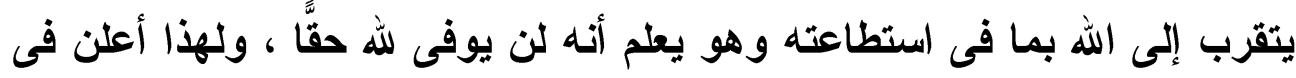

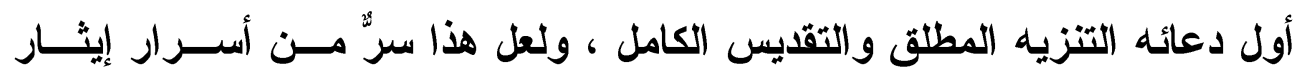

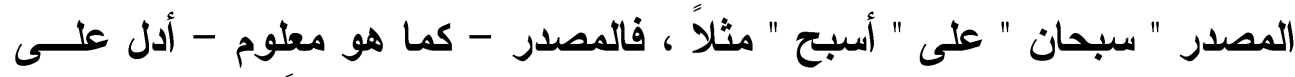

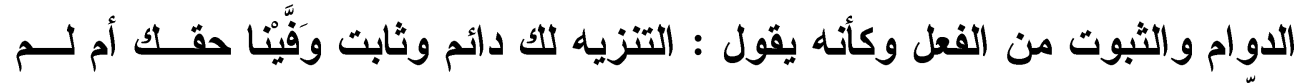

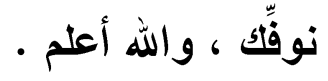

\section{الدواء الثانى :}

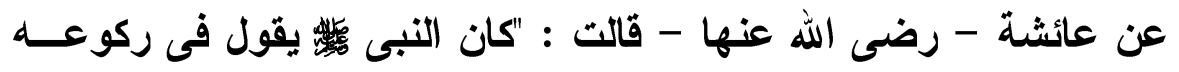

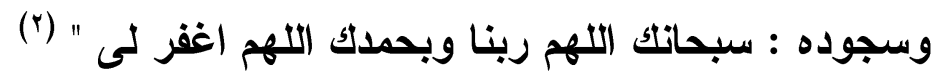

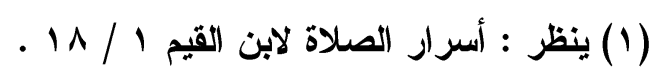

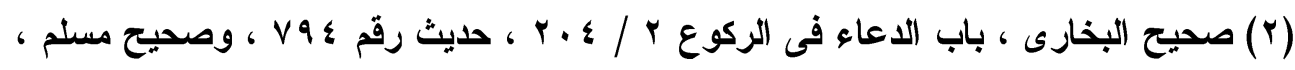

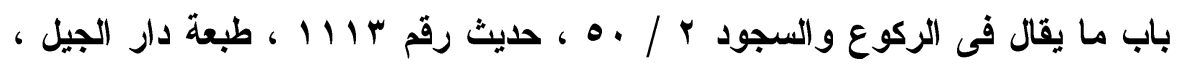

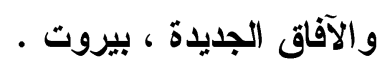




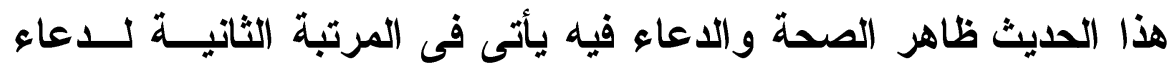

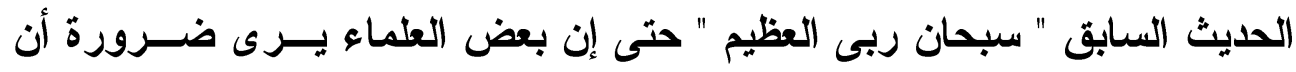

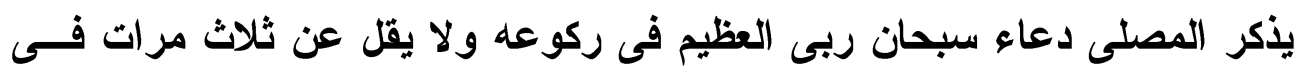

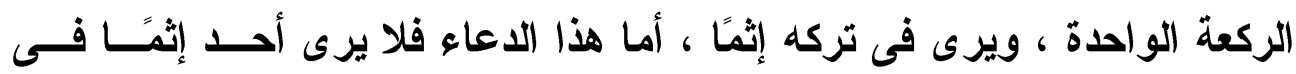

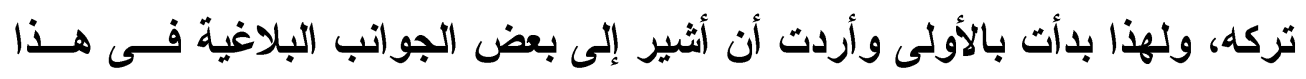

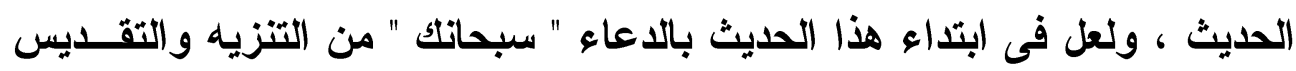

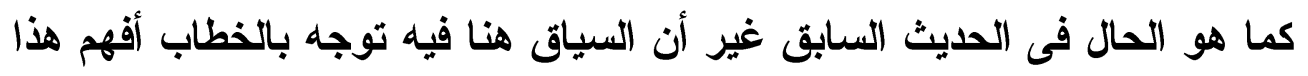

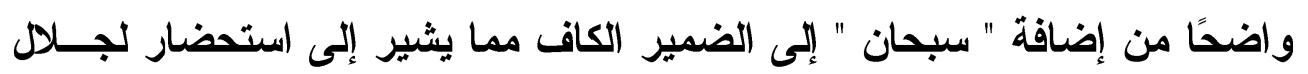

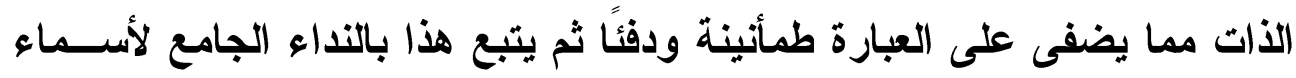

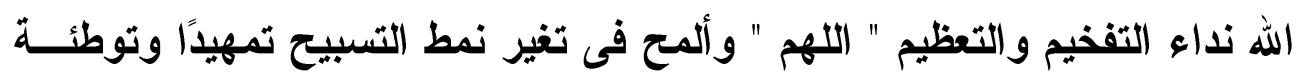

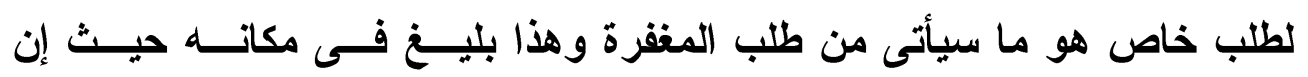

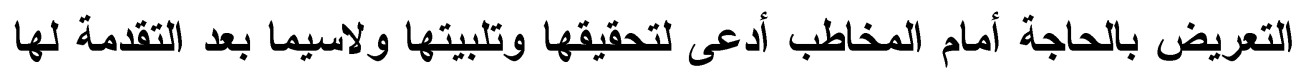

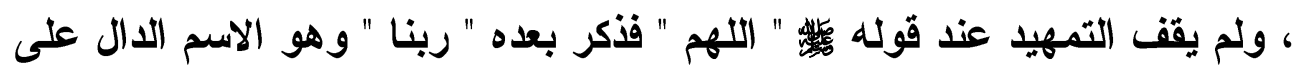

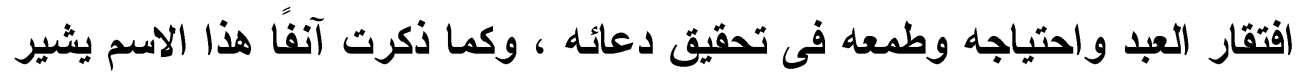

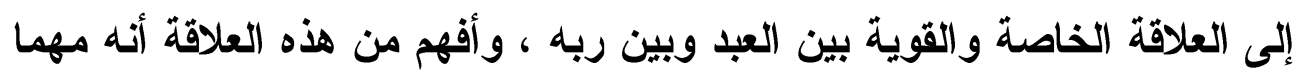

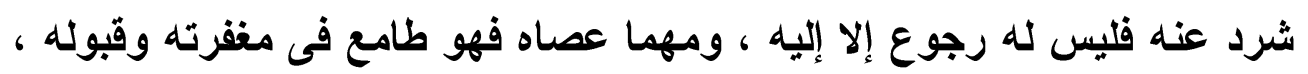

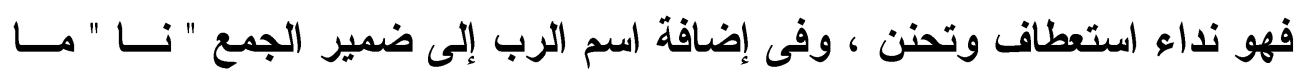

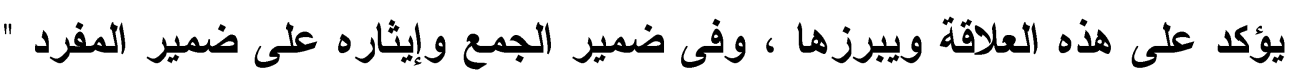

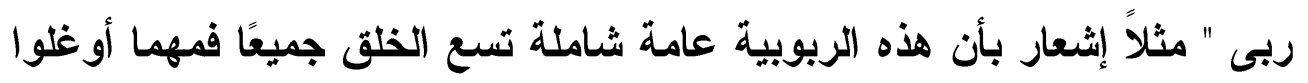

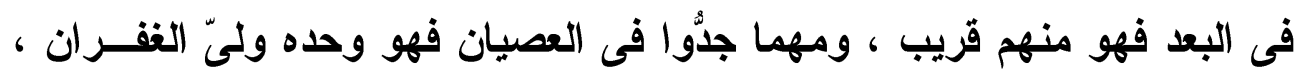

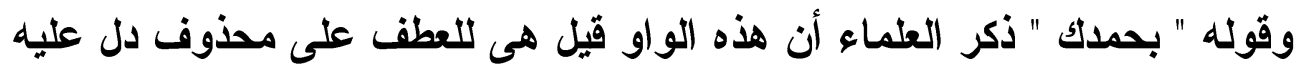

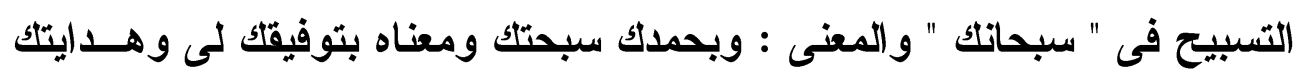

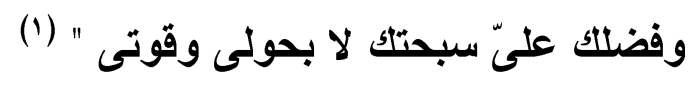

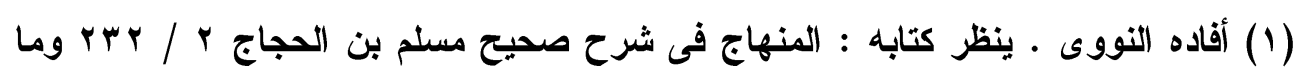

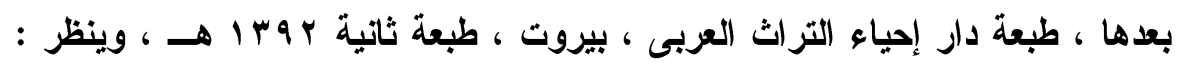


قال البدر العينى : " والواو فيه إما للحال وإما لعطف الجملة على الجملة

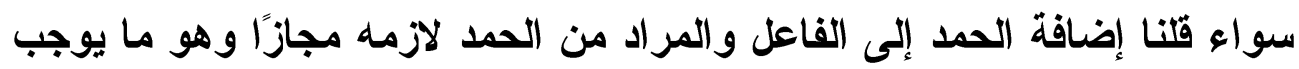

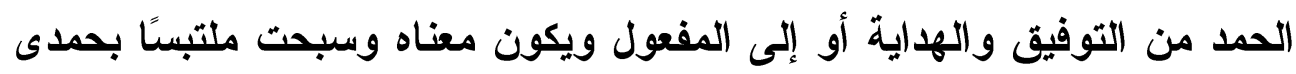

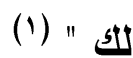

قال الثيخ أبو العباس القرطبى : " ويظهر لـ وجه آخر وهو إبقاء معنى

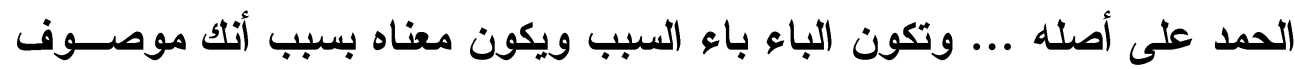

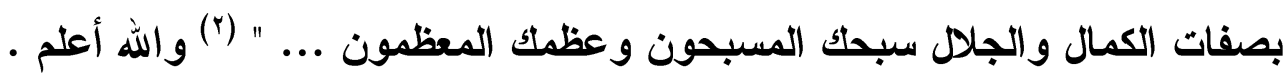

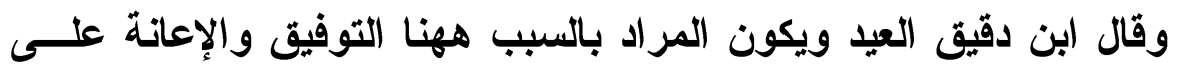

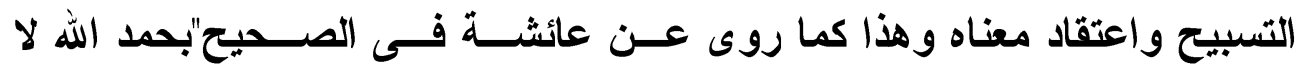

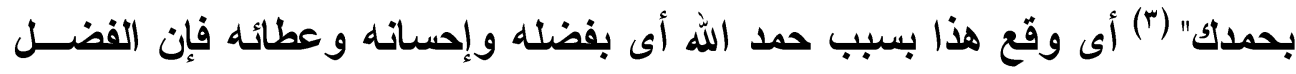

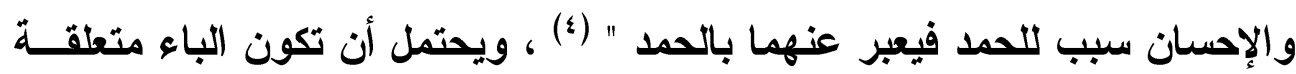

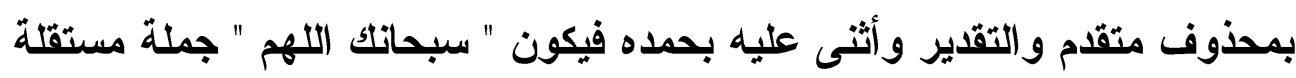

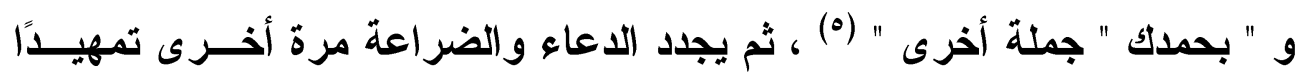

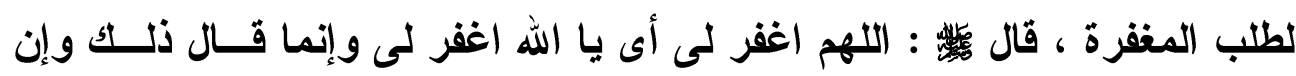

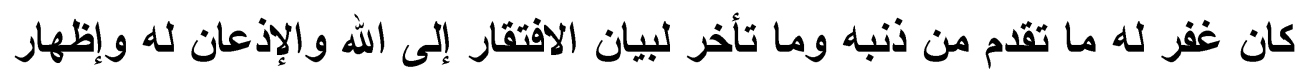

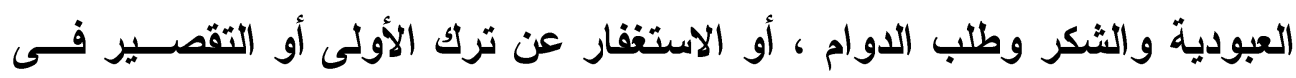

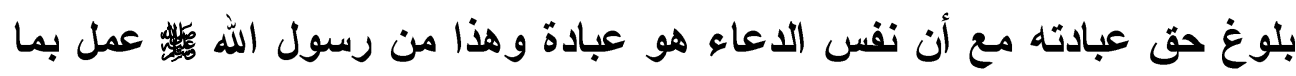

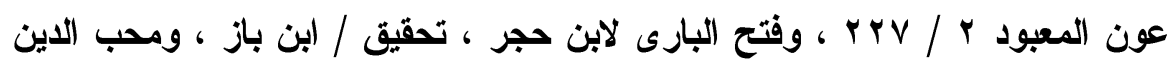

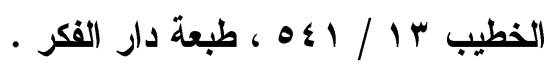

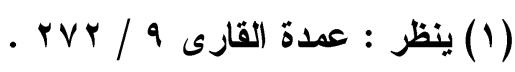

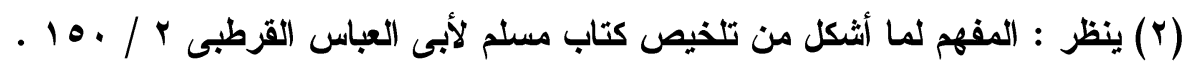

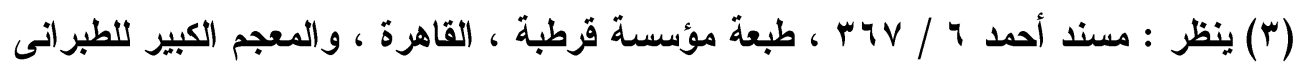

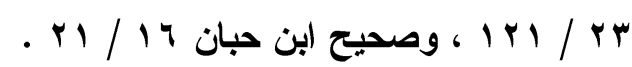

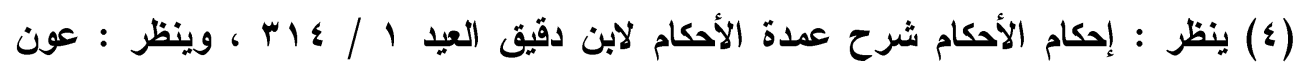

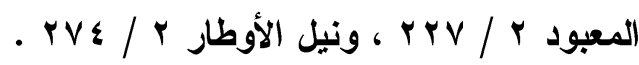

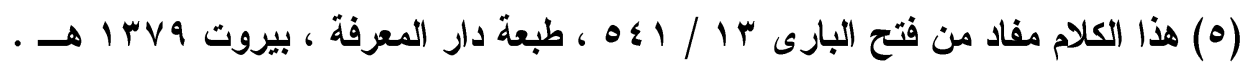




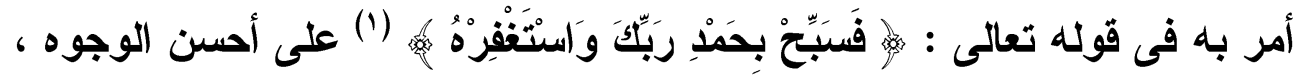

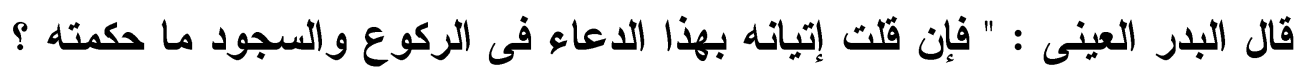

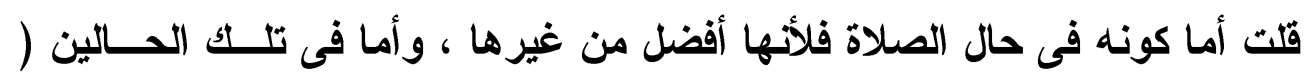

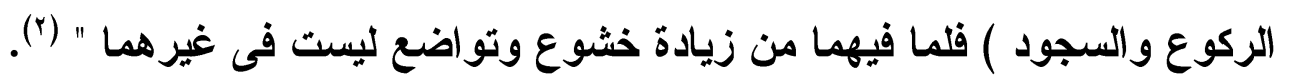

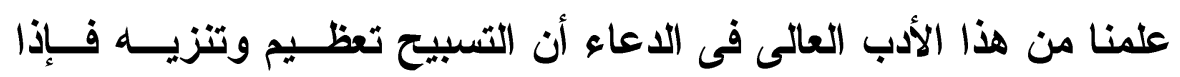

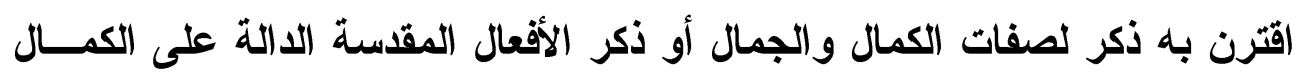

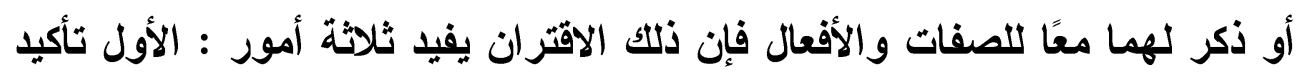

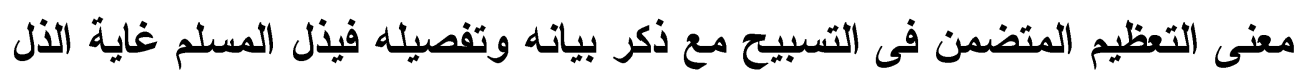

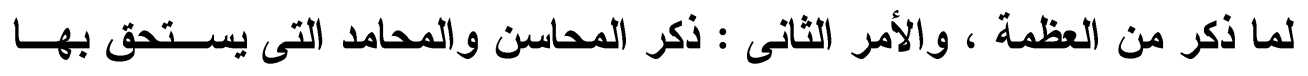

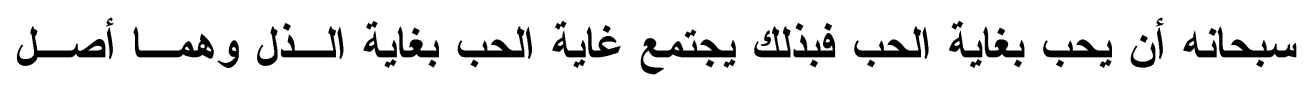

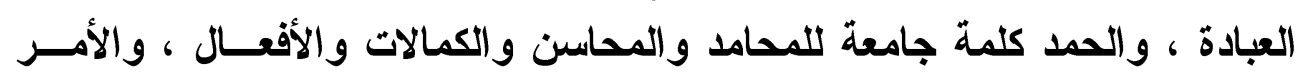

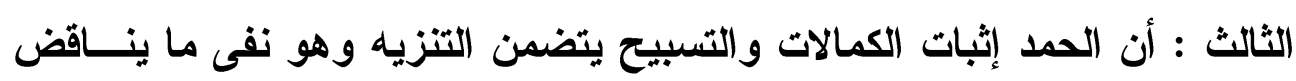

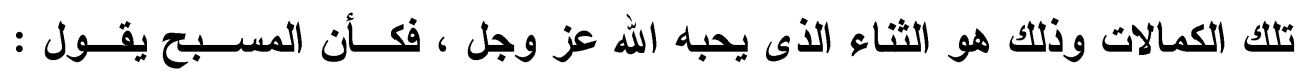

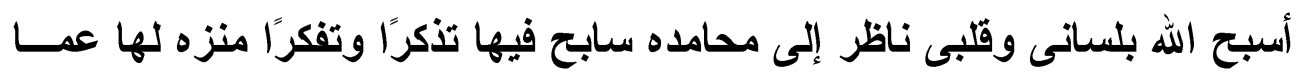

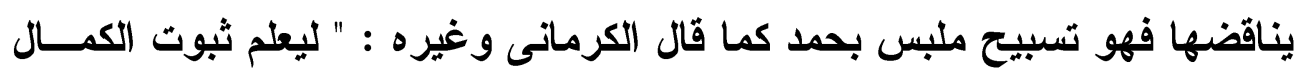

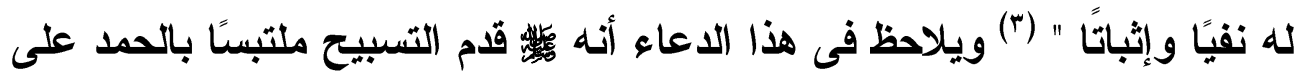

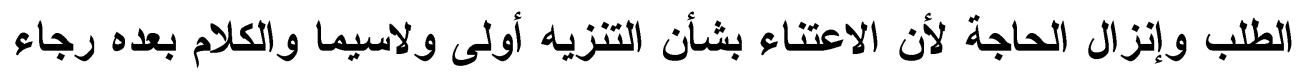

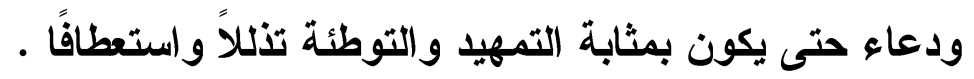

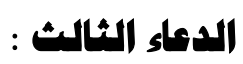

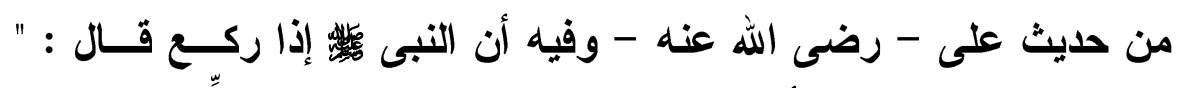

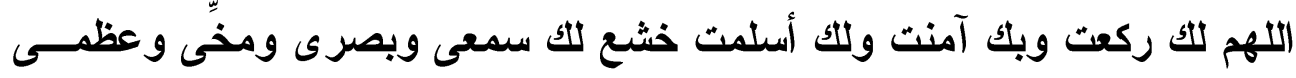

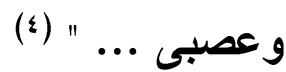

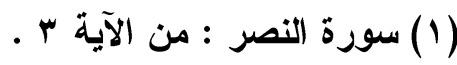

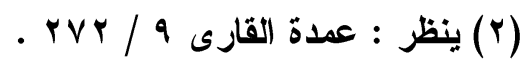

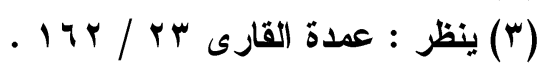

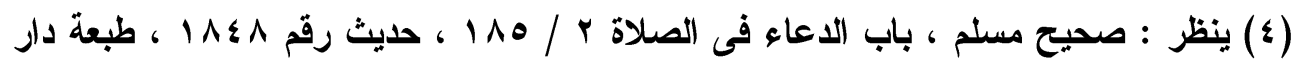

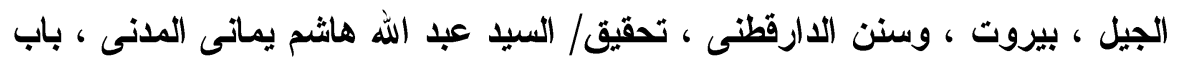


هذا دعاء آخر صحيح ورد عن النبى لئس ينص على الإذعان والإعلان لله

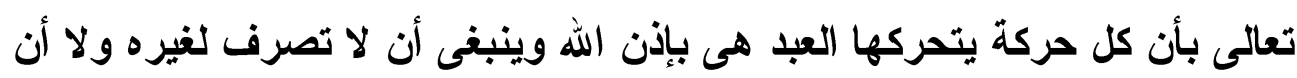

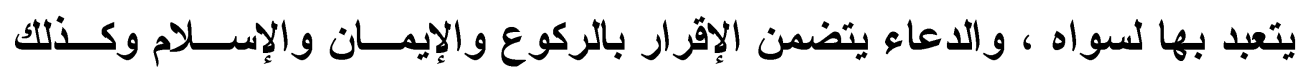

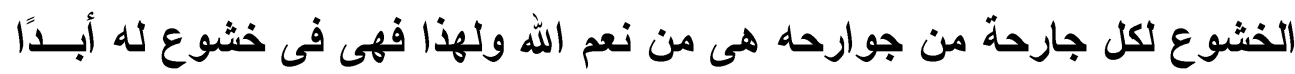

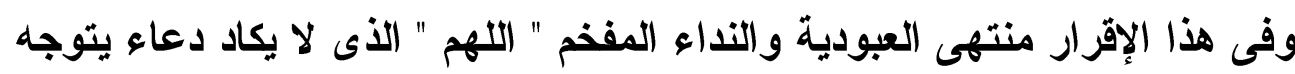

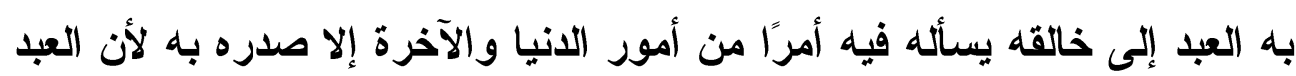

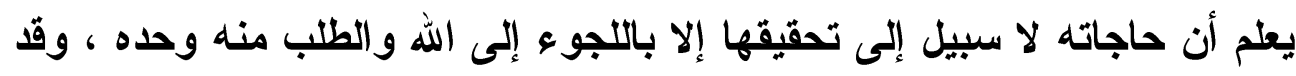

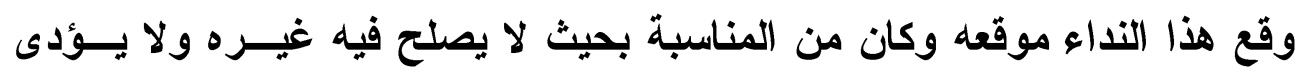

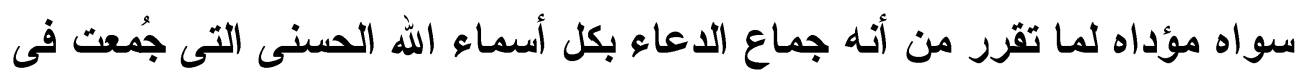

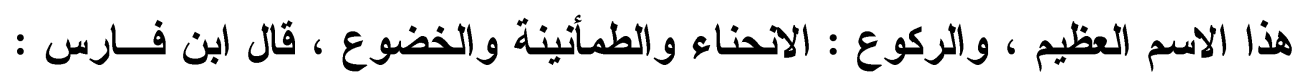

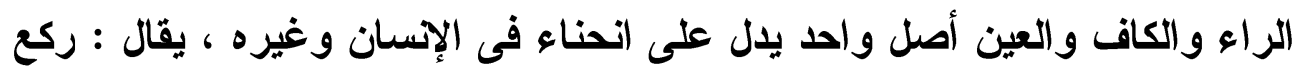

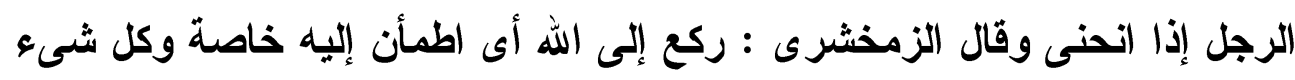

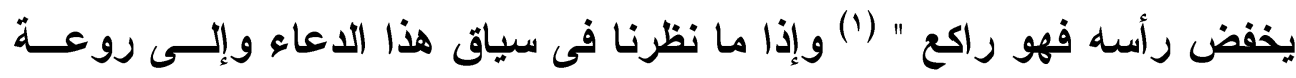

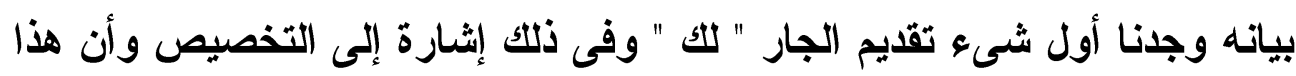

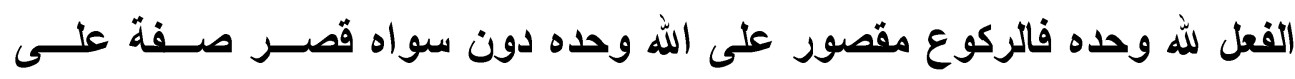

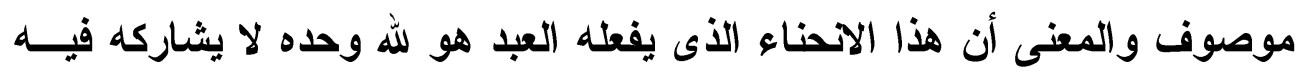

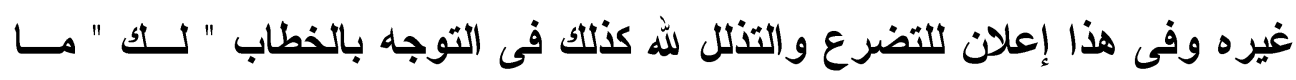

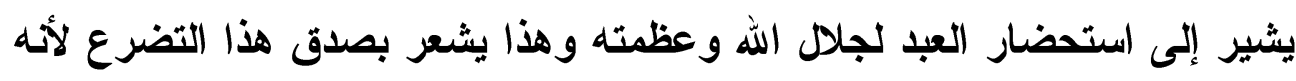

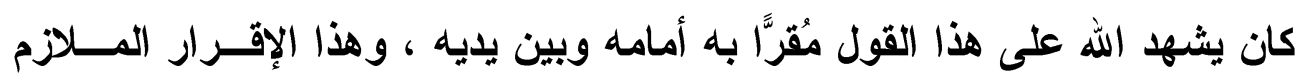

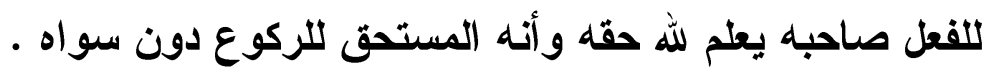

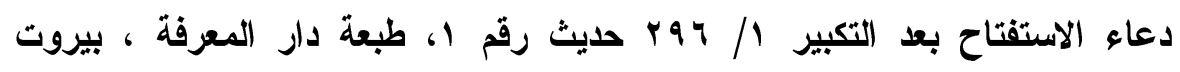

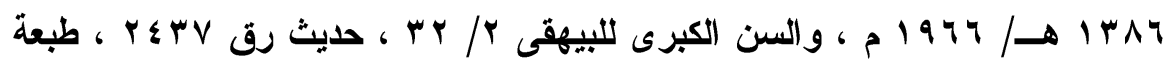

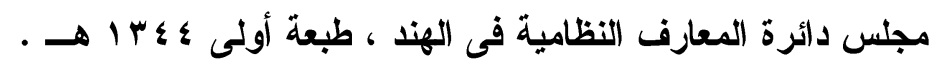

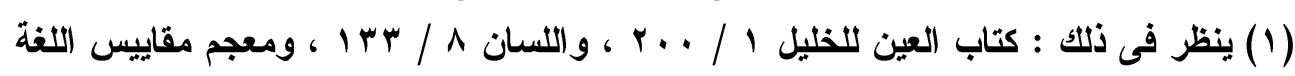

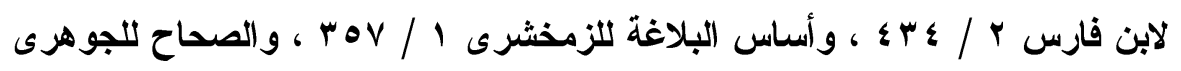

$$
\text { . rov / \& }
$$




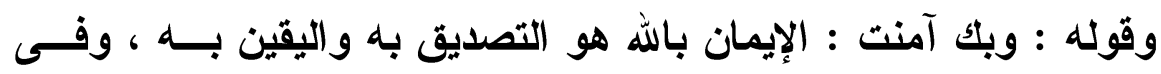

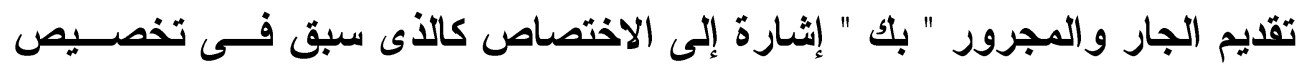

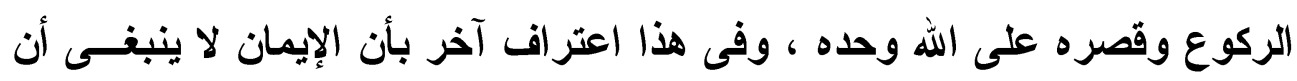

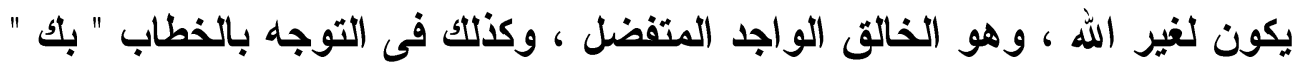

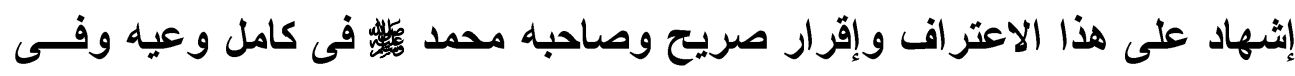

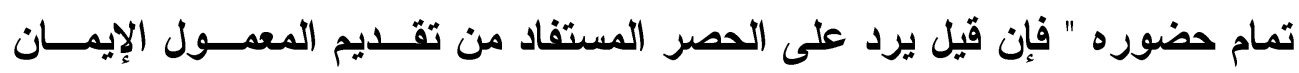

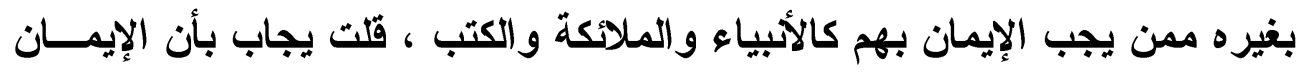
بما أوجبه إيمان به أو المراد الحصر الإضافى بالنسبة لمن عبد " (1) .

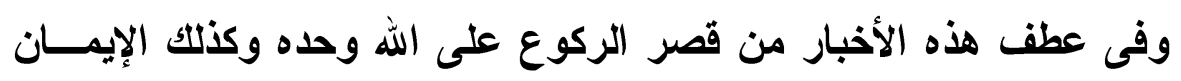

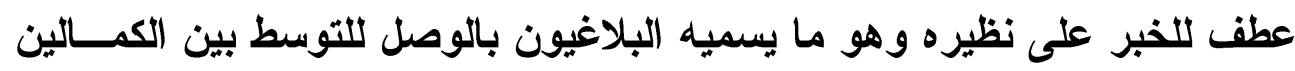
و المناسبة ظاهرة بين الركوع والإيمان وفى تقديم الركوع على الإيمان ، والإيمان

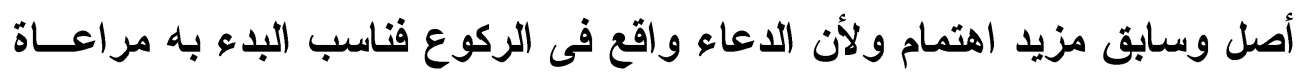

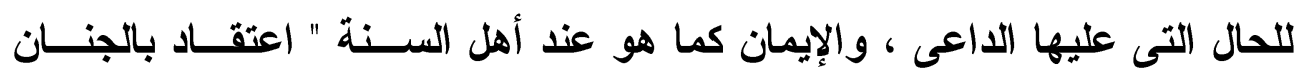

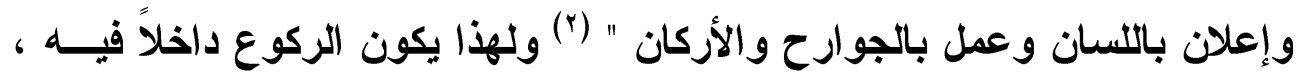

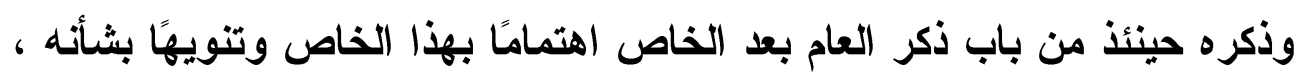

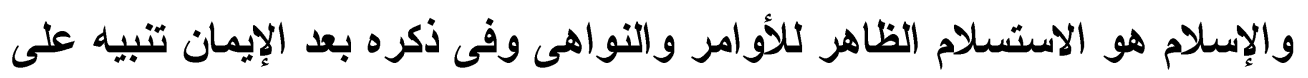

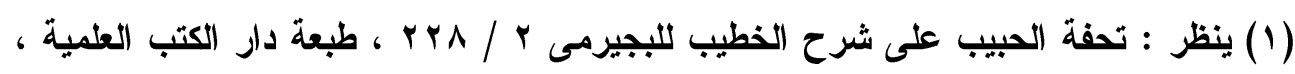

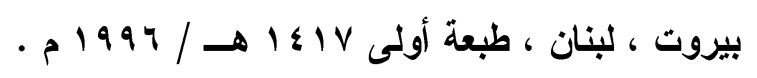

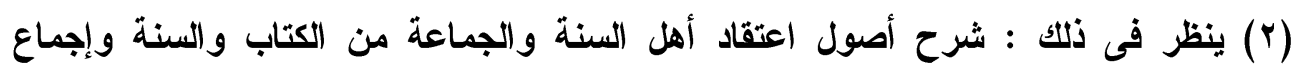

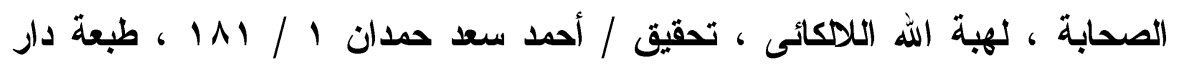

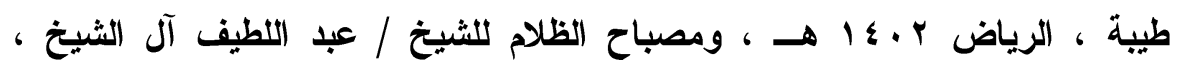

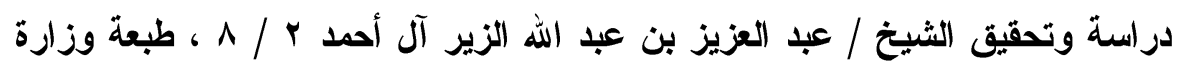

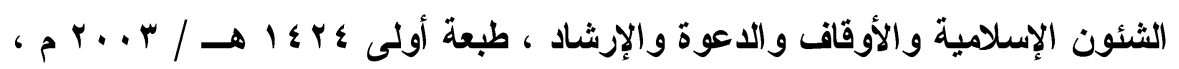

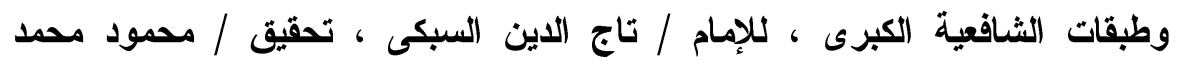

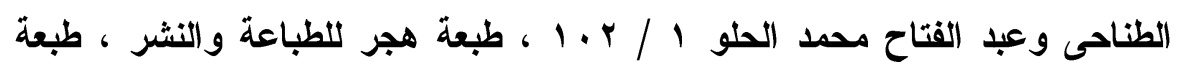

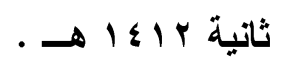




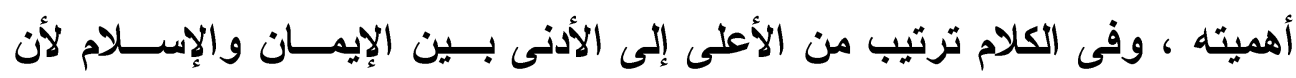

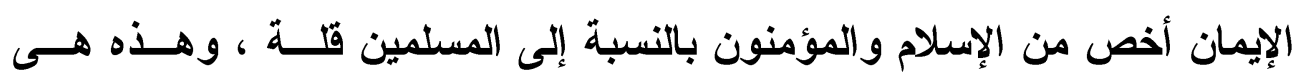

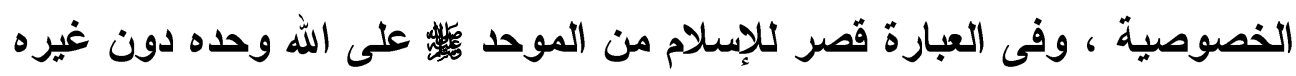

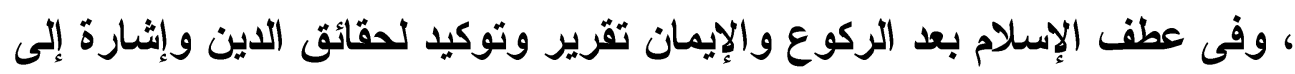

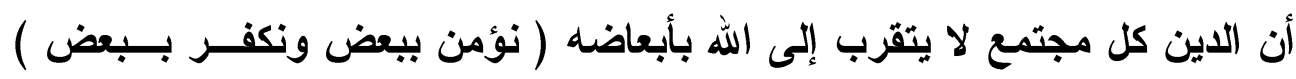

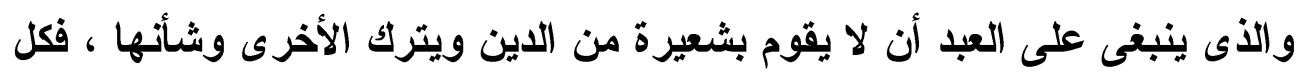

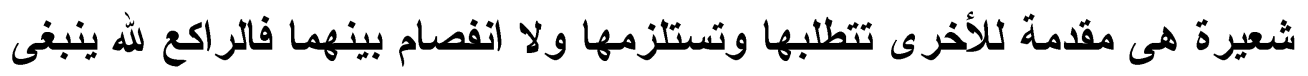

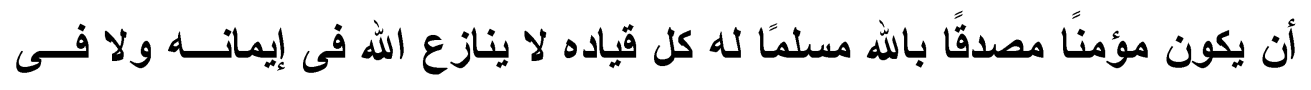

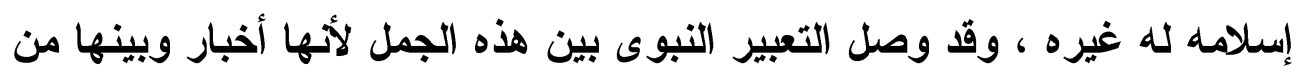

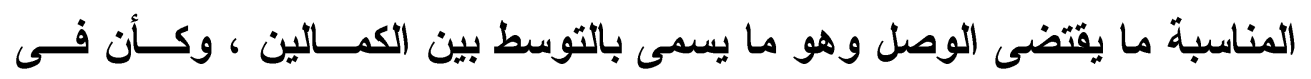

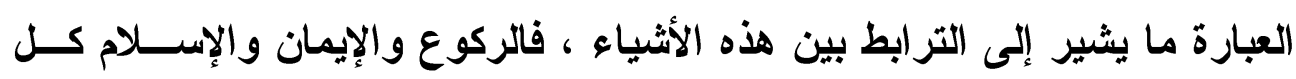

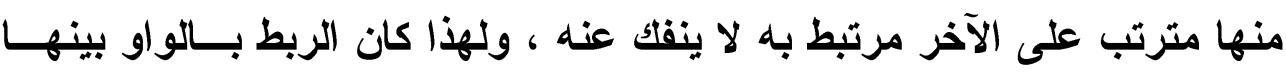

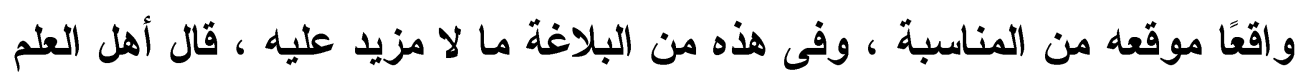

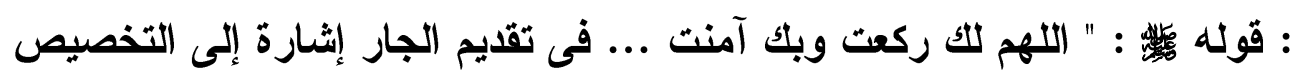

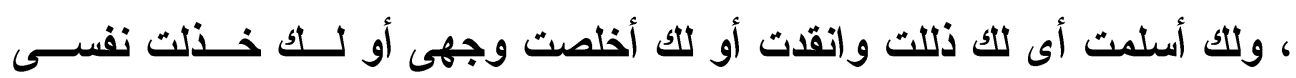

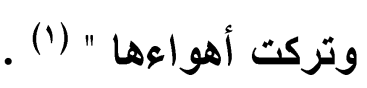

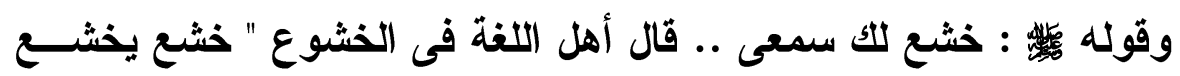

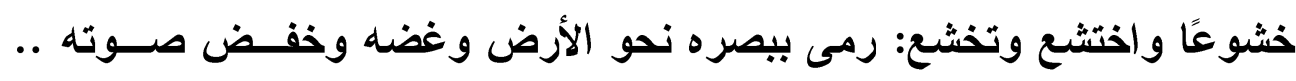

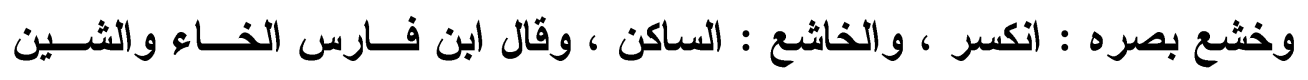

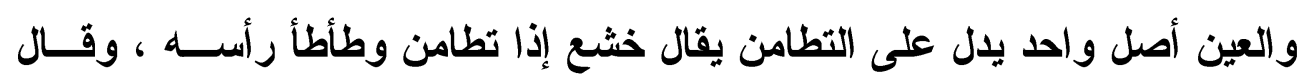

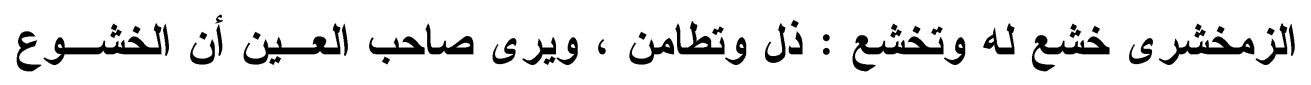

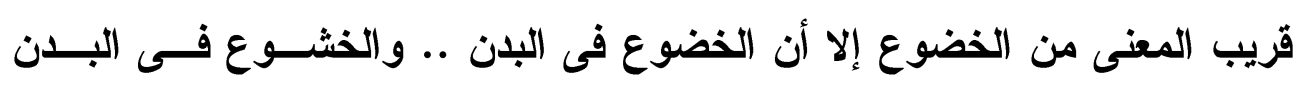

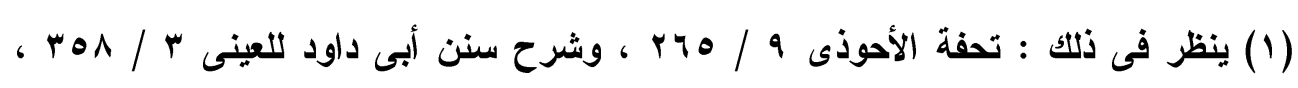

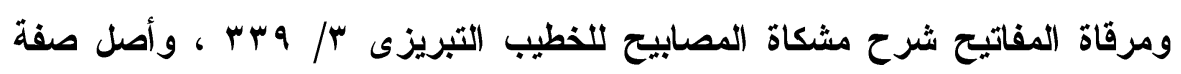

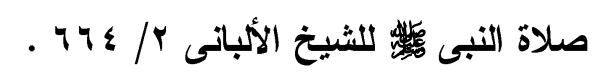


والصوت والبصر ، وقالوا: الخاشع المستكين ، والخاشع : الر اكع " (1) ، ومعنـى

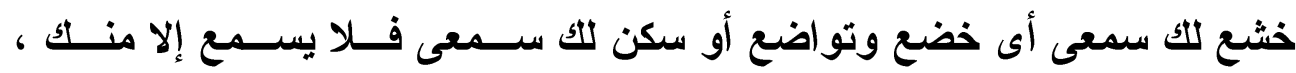

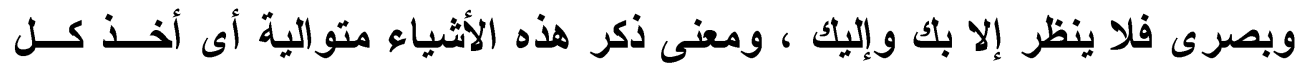
عضو من هذه الأعضاء حظه من الخضوع والتذلل أى سكنت وافتقرت ، وقوله :

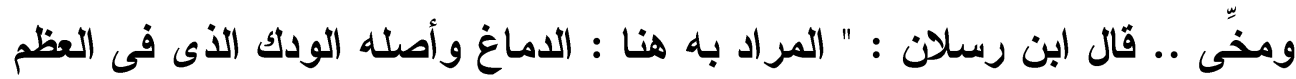

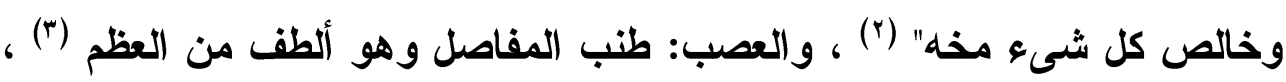
و المر اد بخشوع هذه الأشياء : الاتقياد والطاعة فيكون هذا من قبيل ذكر الــلازم

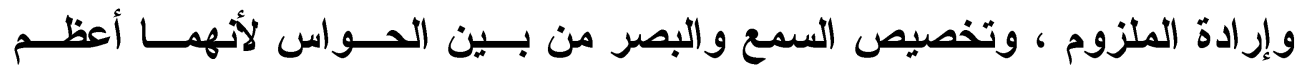

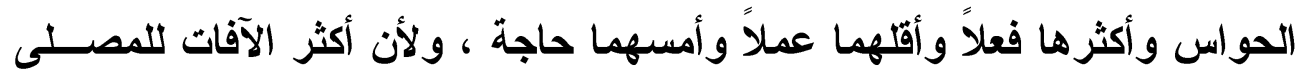

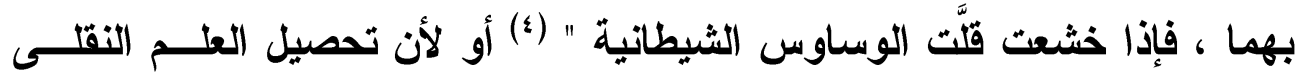
و العقلى بهما (•) وأما تخصيص المخ والعظم والعصب فلأن ما فى أقصــى قعـر

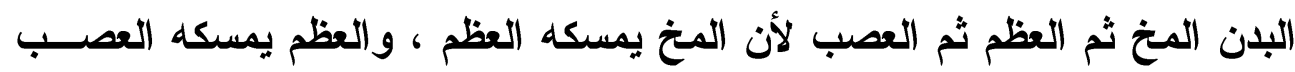

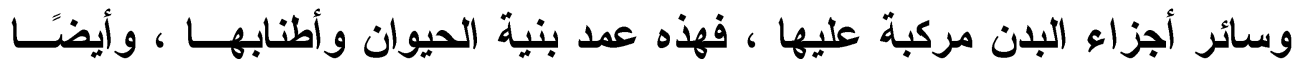

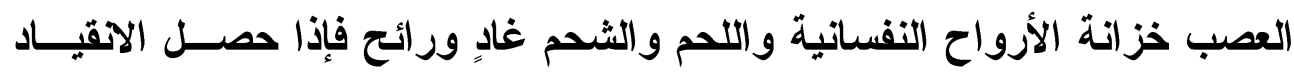
والطاعة من هذه فمن الأى يتركب عليها بالطريق الأولى ، فإن قلت : ما معنسى

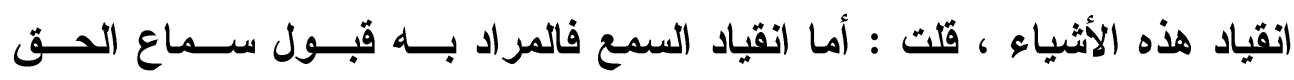
والإعراض عن سماع الباطل ، وأما انقياد المخ والعظم والعصب فالمر اد به انقياد باطنه كانقياد ظاهره ، لأن الباطن إذا لم يوافق الظاهر لا يكون انقيــاد الظــاهر

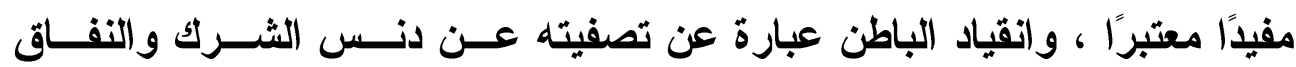

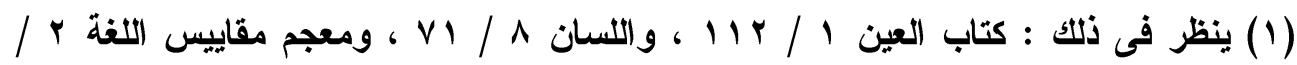

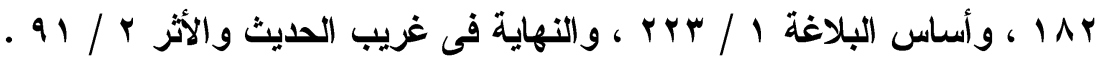

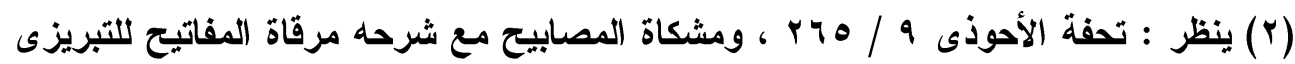
. $119 / r$

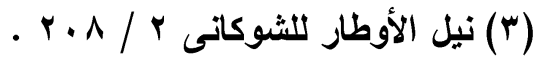

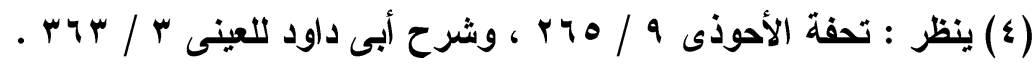

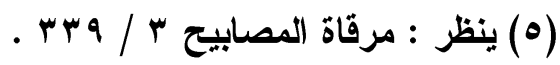


وتزيينه بالإخلاص والعلم والحكمة ، وترك الغل والغش والحقد والحسد والظنون

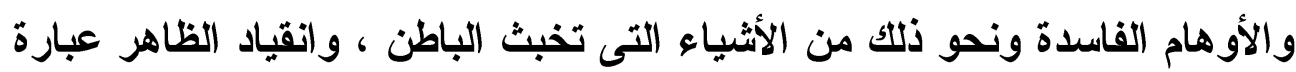

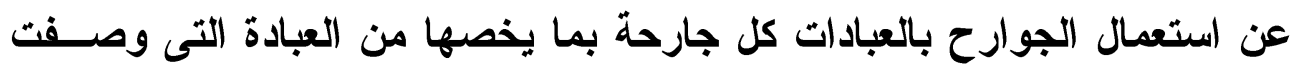

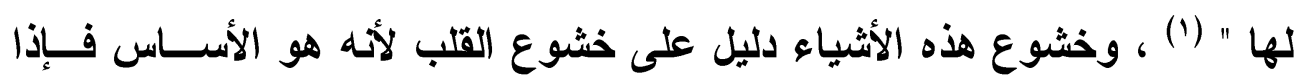

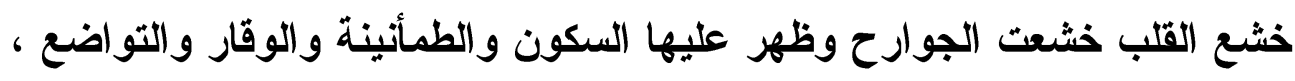

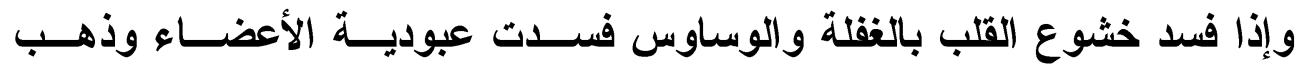

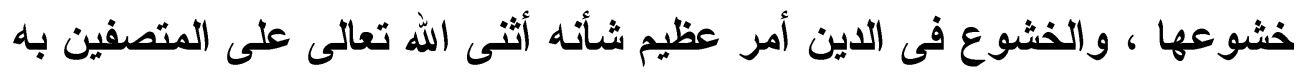

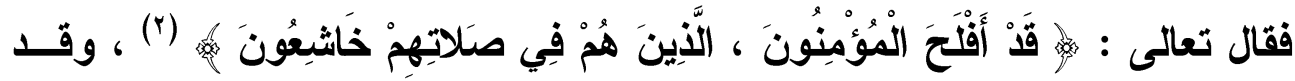

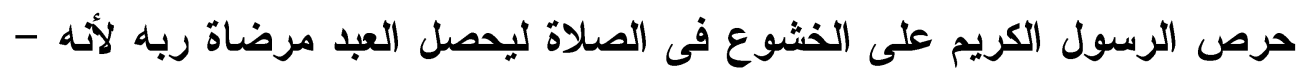

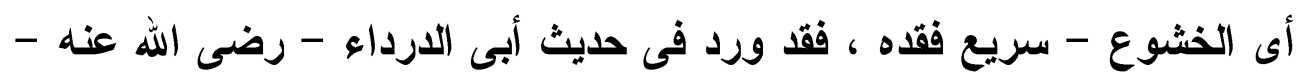

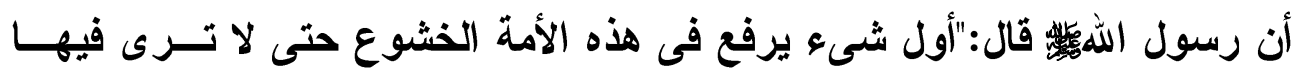

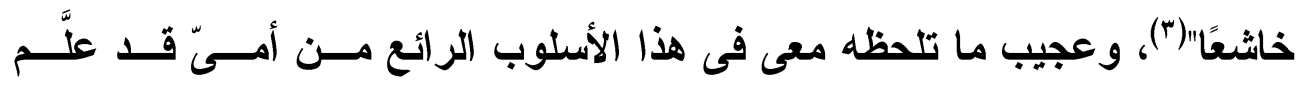

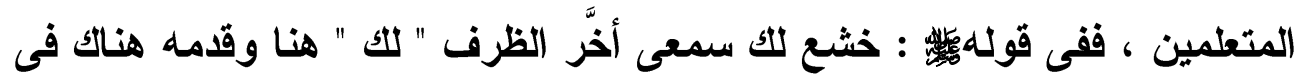

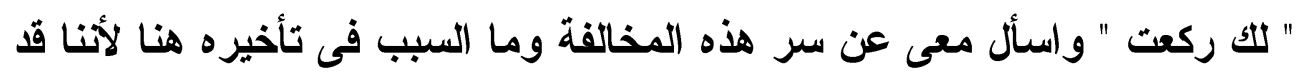

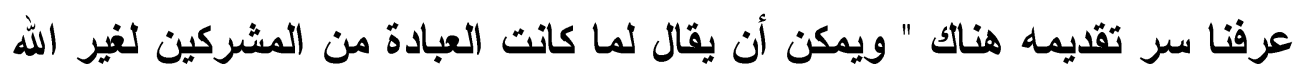

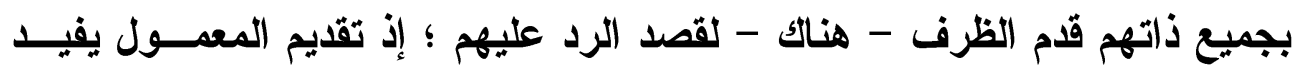

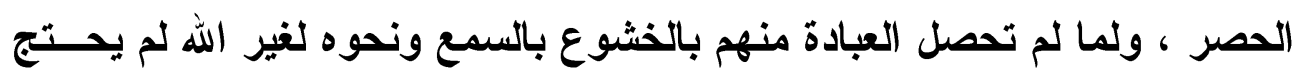

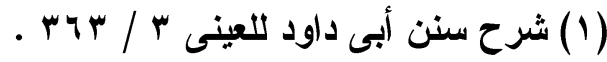

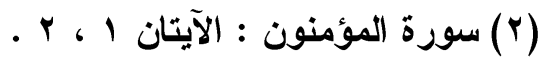

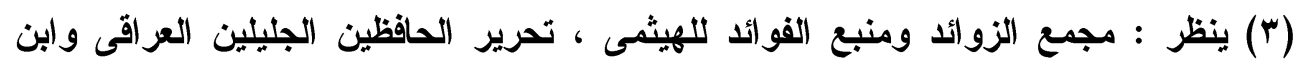

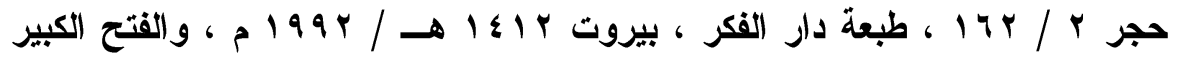

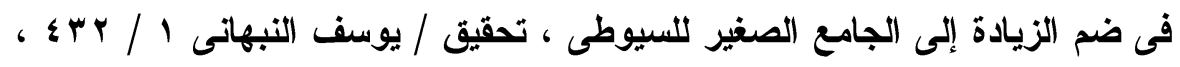

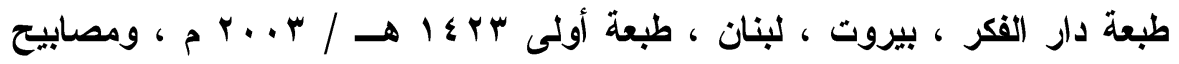

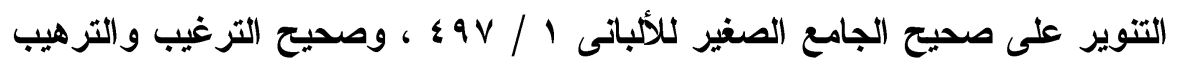

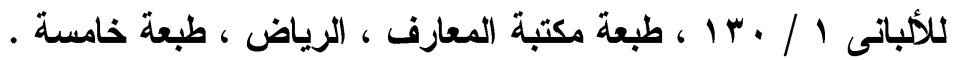




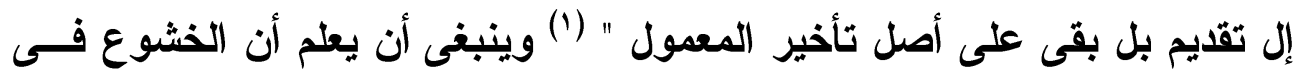

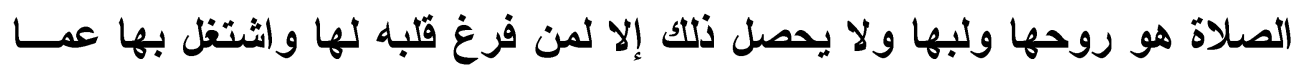

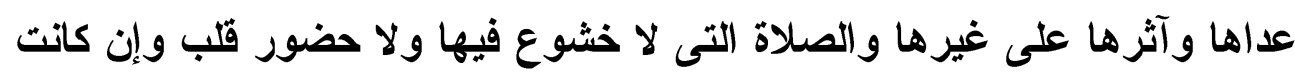

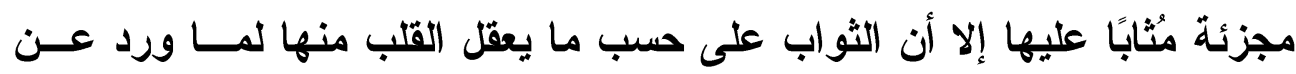

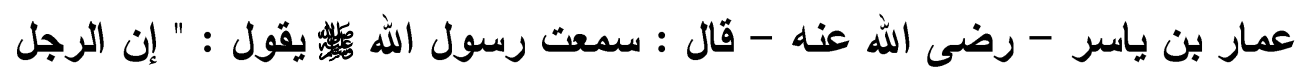

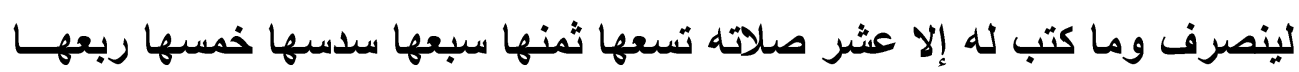

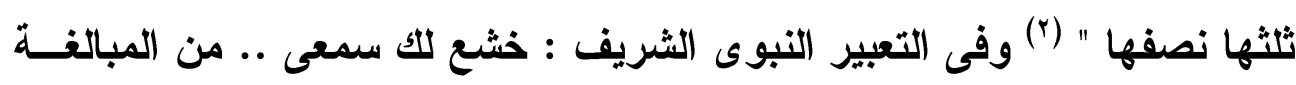

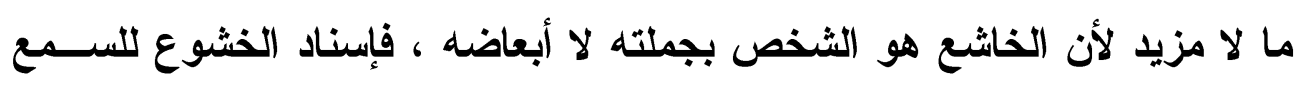

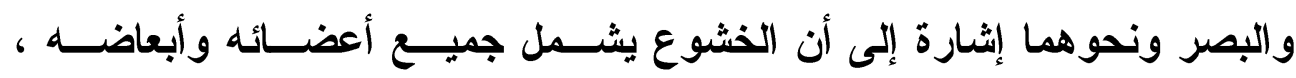

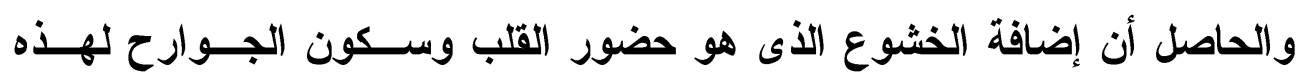

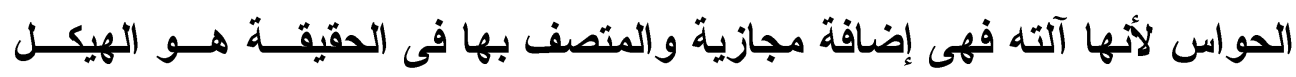

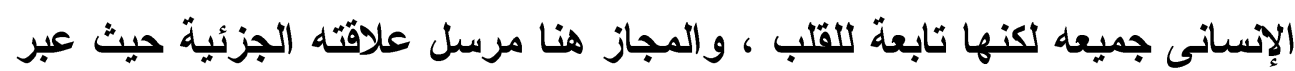

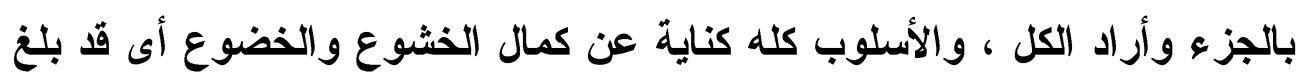

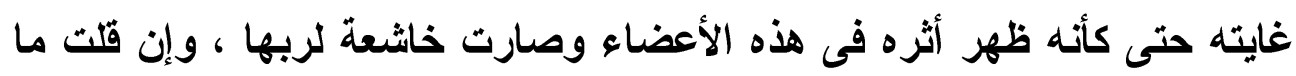

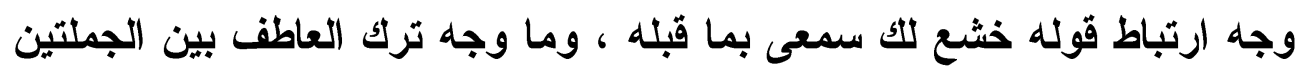

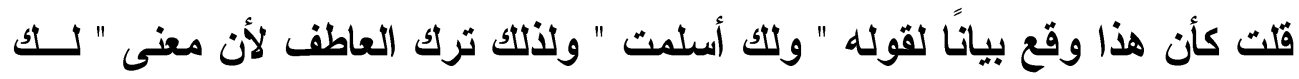

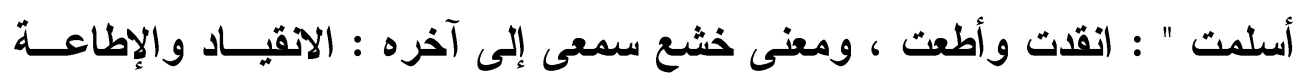

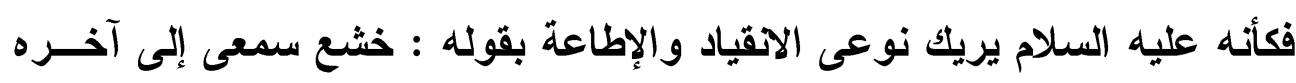

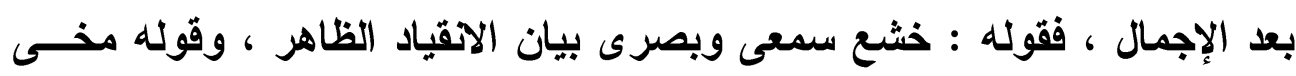

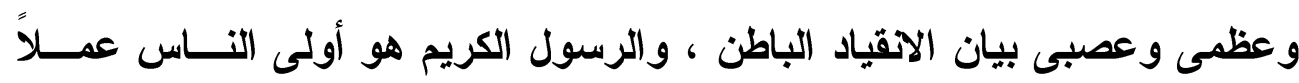

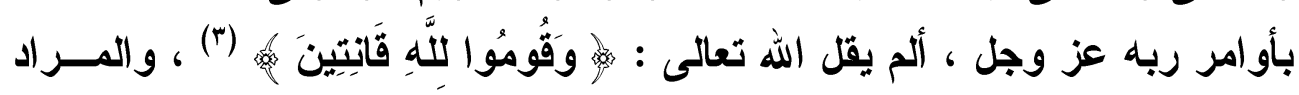

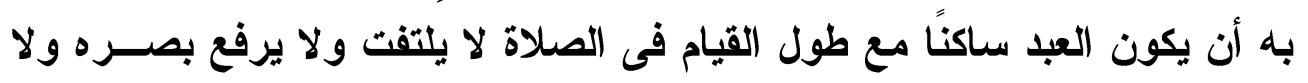

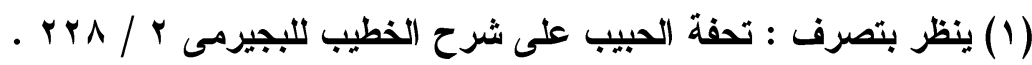

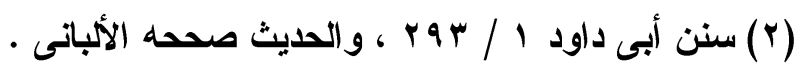

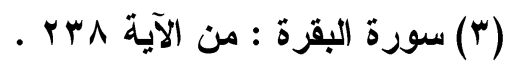




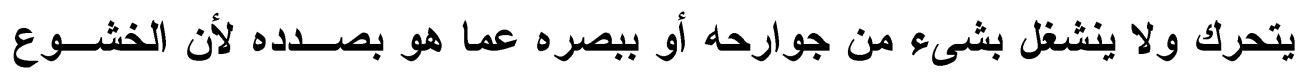

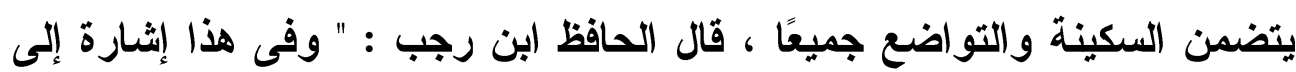

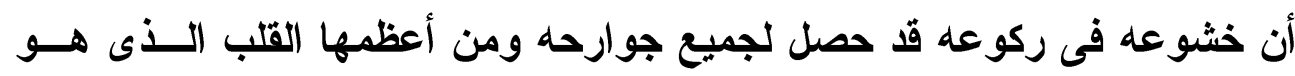

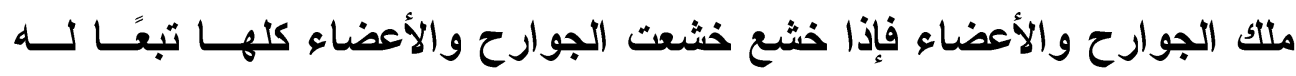

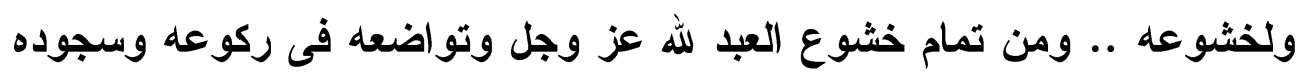

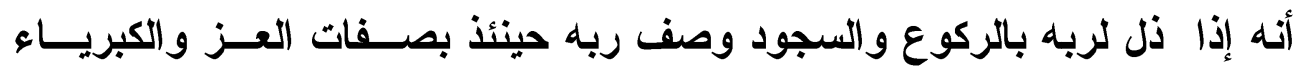

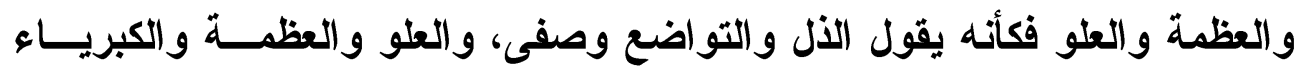

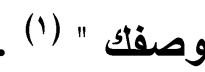

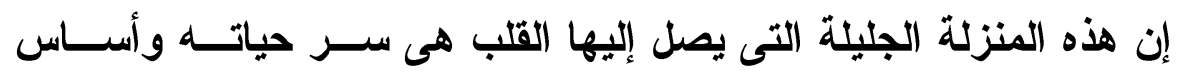

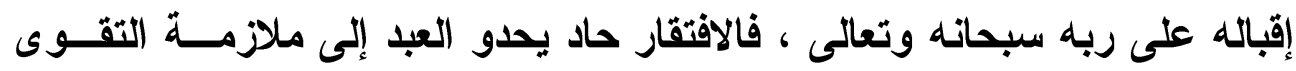

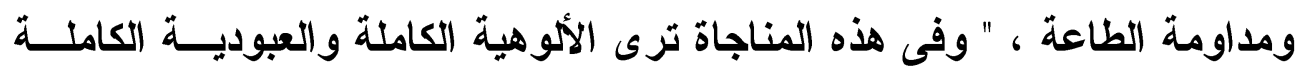

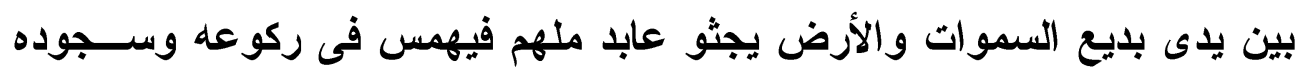

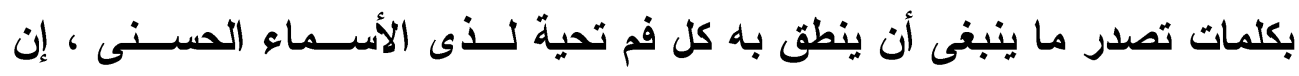

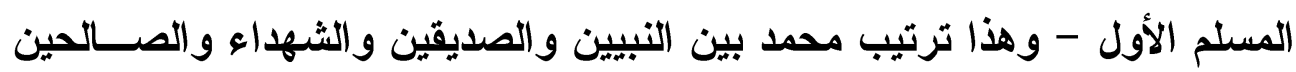

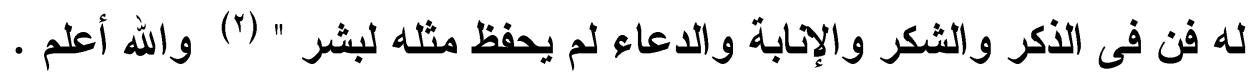

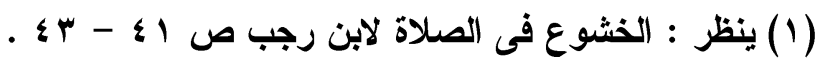

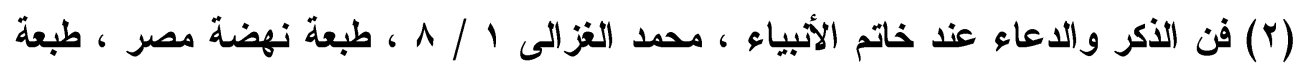

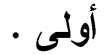




\section{المبحث الثالث}

\section{ها يقال من الدماء بعد الرفع من الركمع}

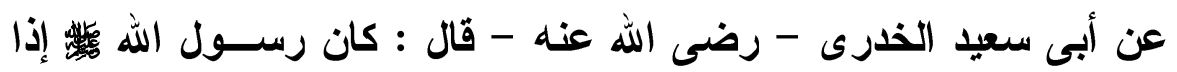

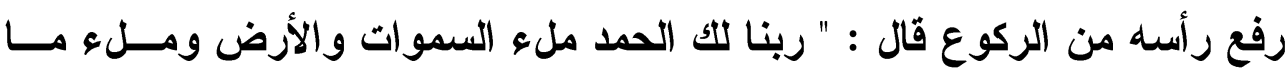

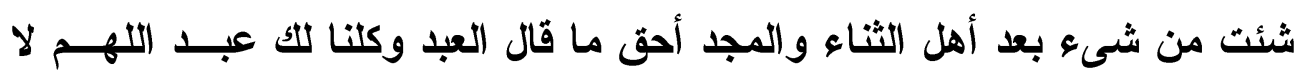

مانع لما أعطيت ولا معطى لما منعت ولا ينفع ذا الجد منك الجد " (1) . فى هذا الحديث الشريف يتوجه النبى

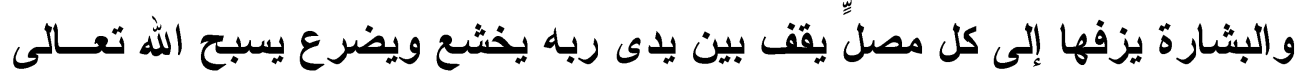

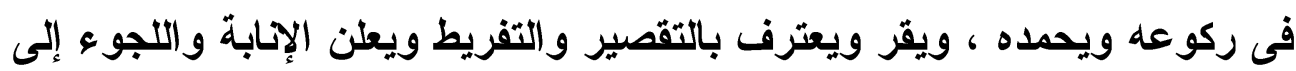
الله تعالى وهذه البشارة ضمان باستجابة دعاء الأاعين وحمد الحامدين " سمع الله

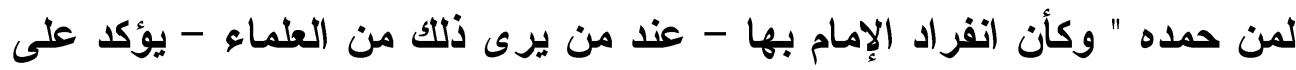

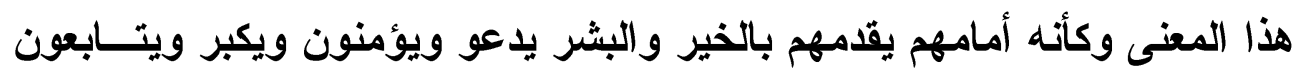

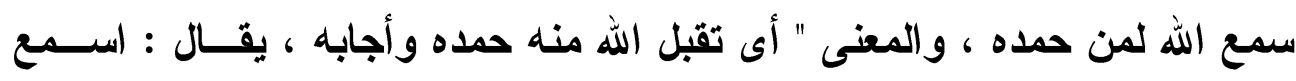

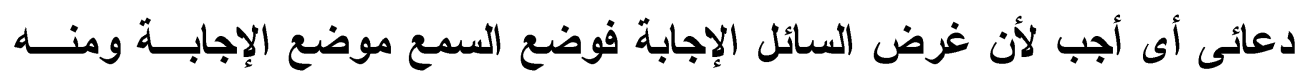

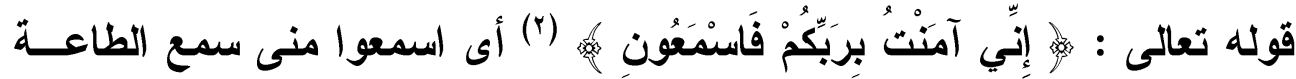

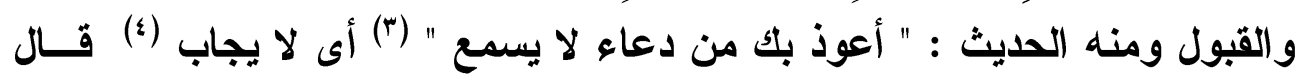

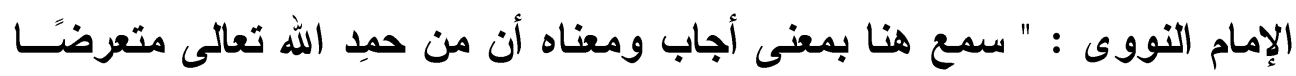

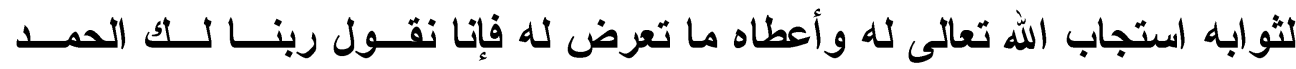

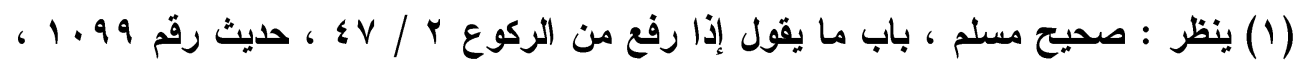

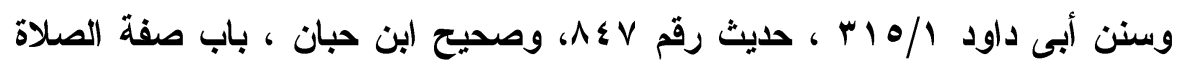

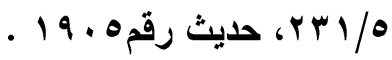

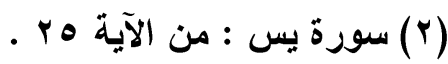

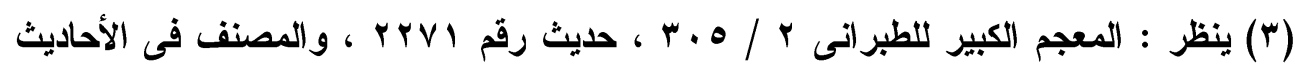

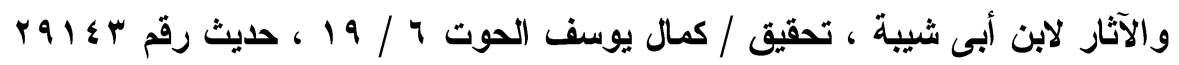

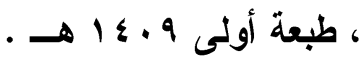

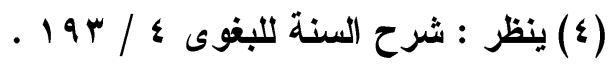


لتحصيل ذلك " (1) ودليل كون السماع هنا بمعنى الاستجابة ثبوت اللام فى قوله :

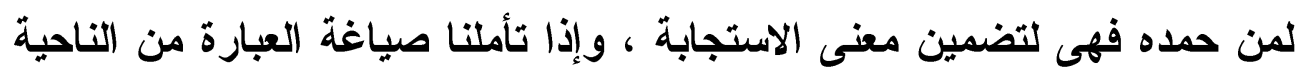

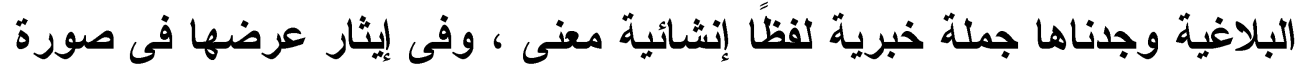

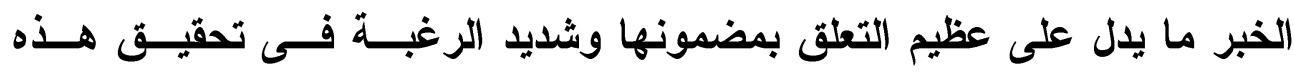

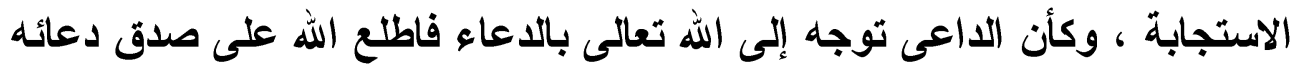

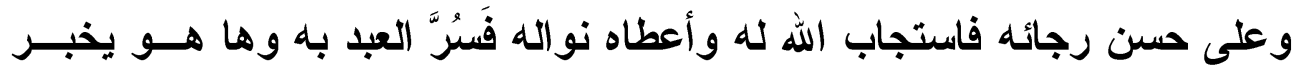

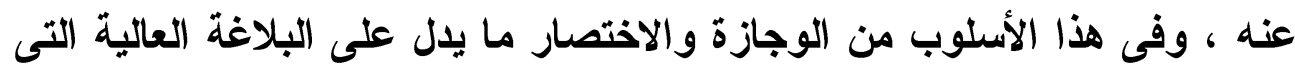

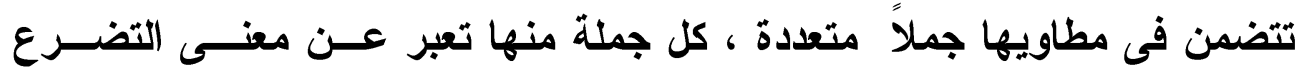

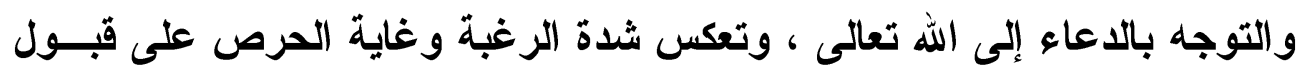
الاعاء وتلبية الرجاء .

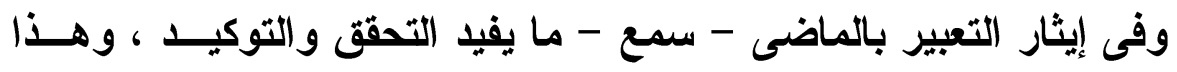

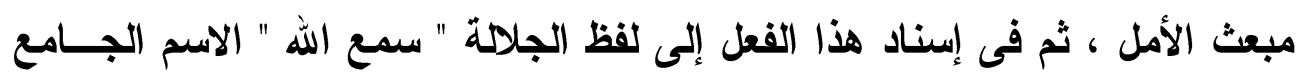

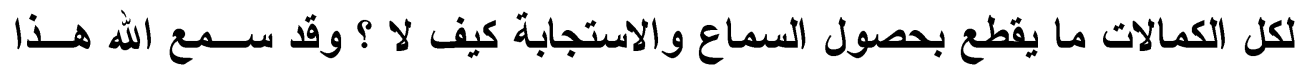
الاعاء من عليائه وأجابه من فوق سمائه وأحس فى هذا هذا الإسناد معنى التشريف

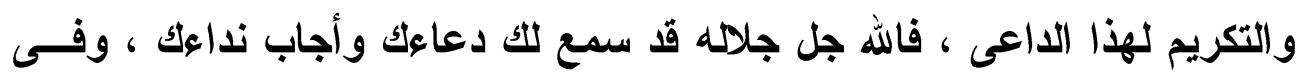

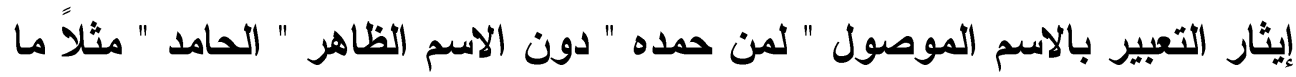

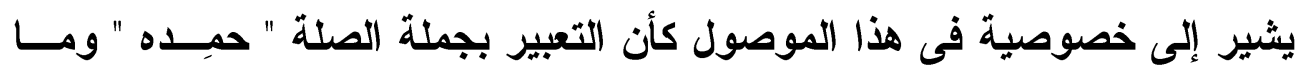

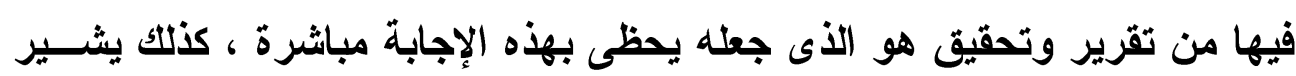

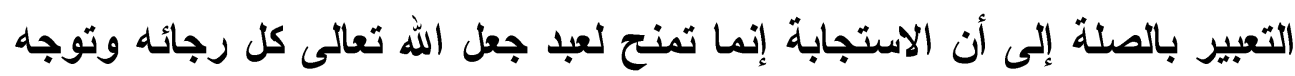

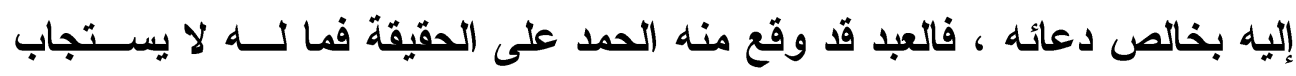

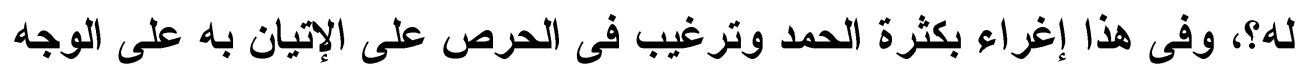

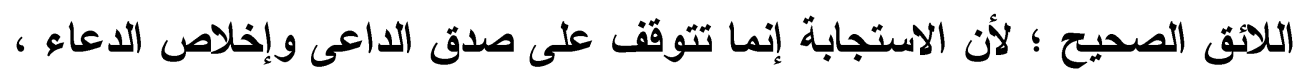

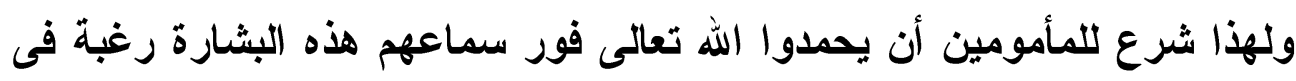

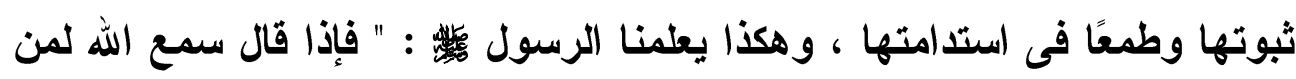




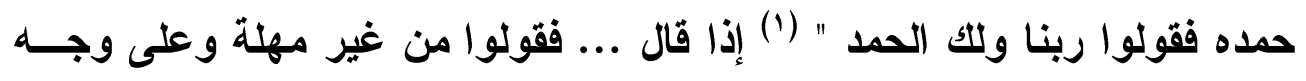

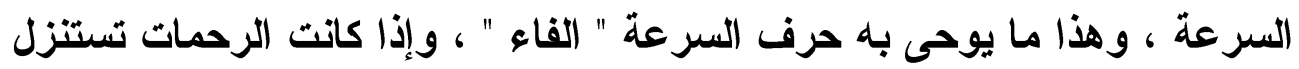

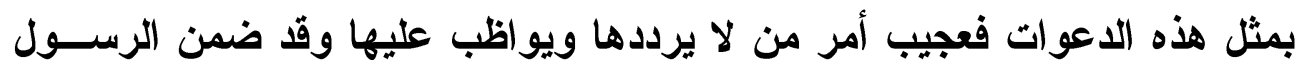

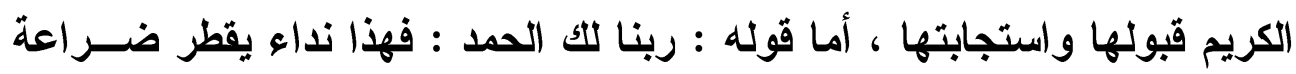

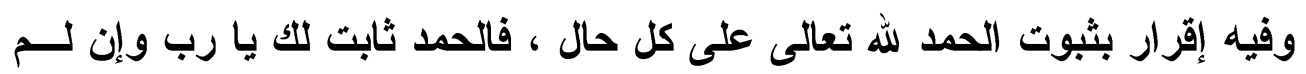

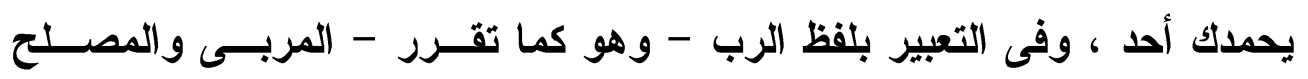

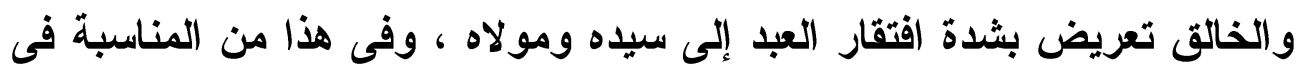

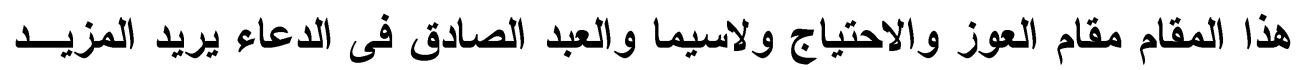

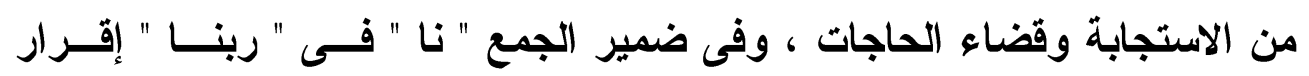

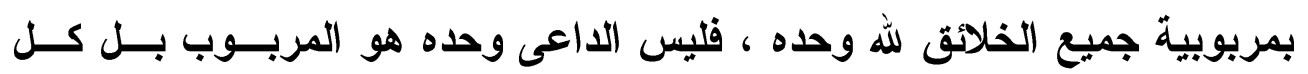

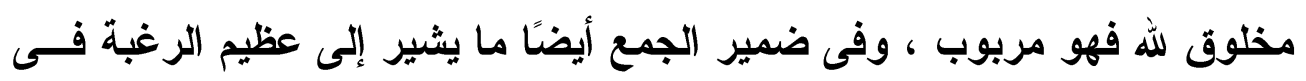

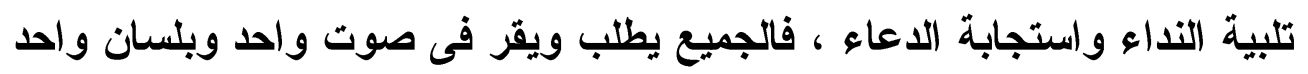

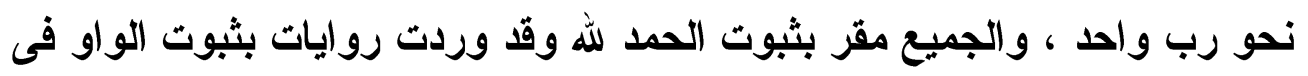

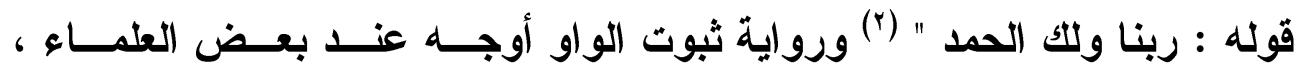

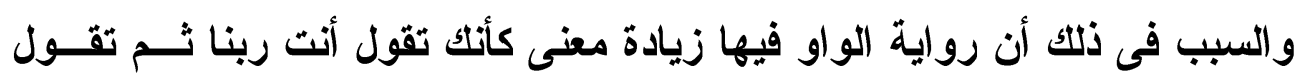

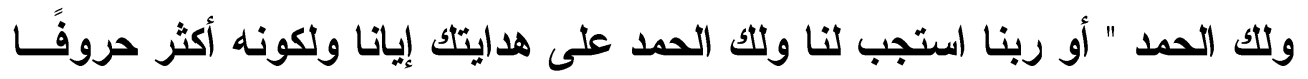

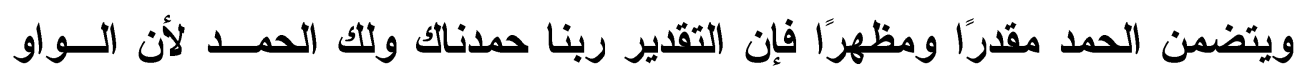

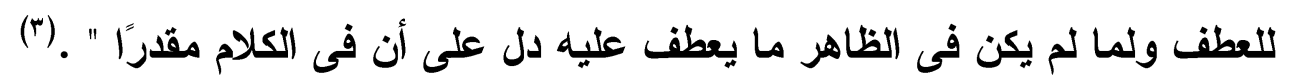

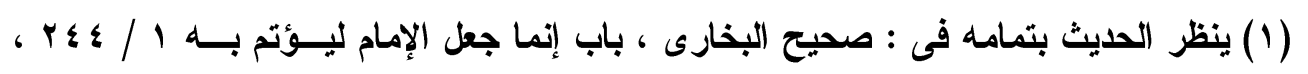

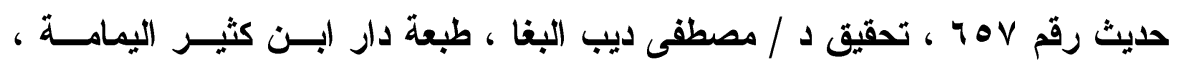

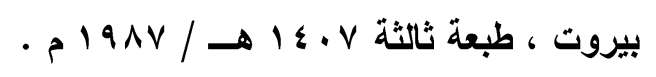

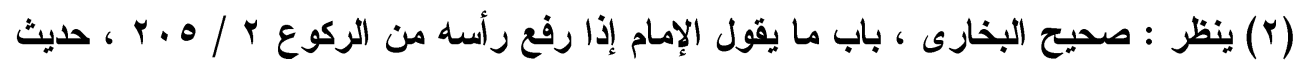

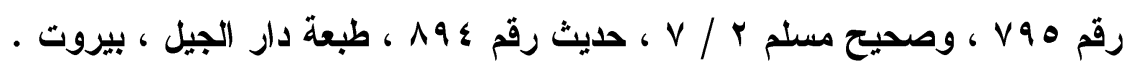

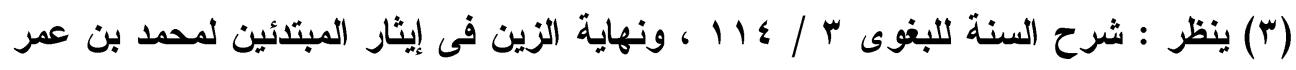

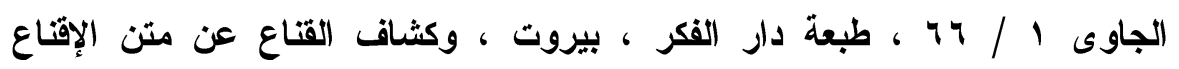

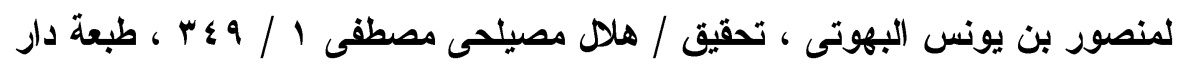




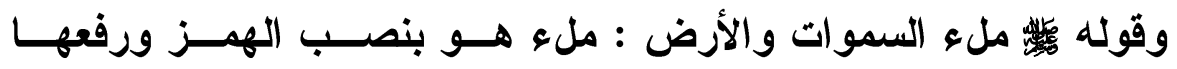

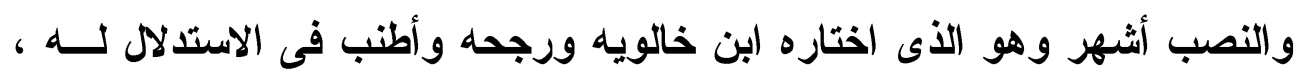

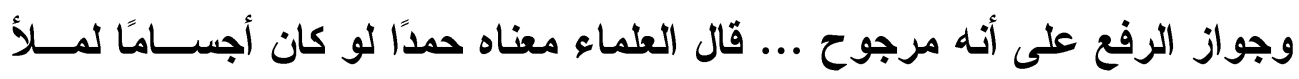

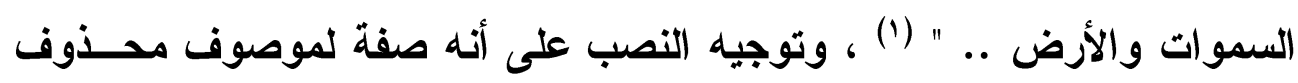

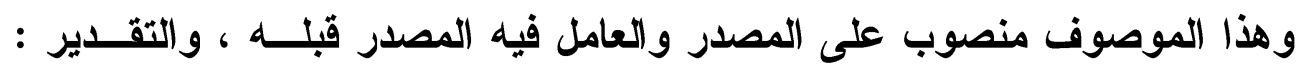

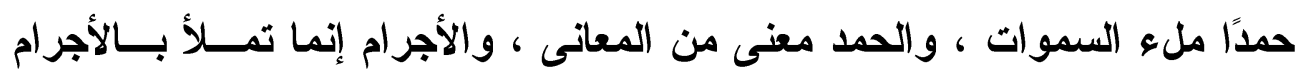

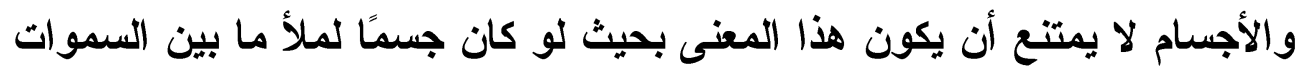

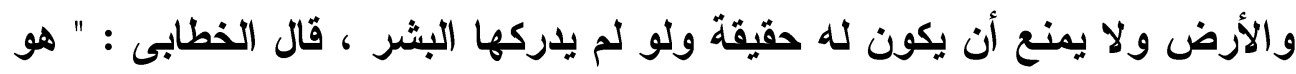

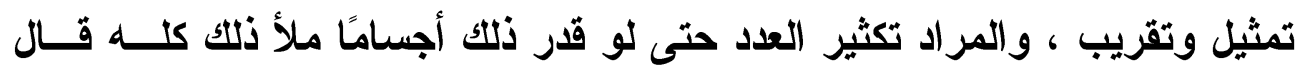

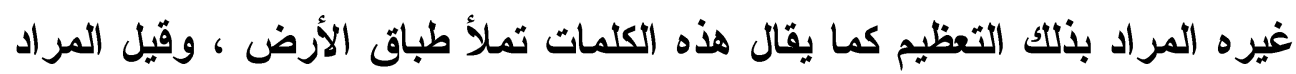

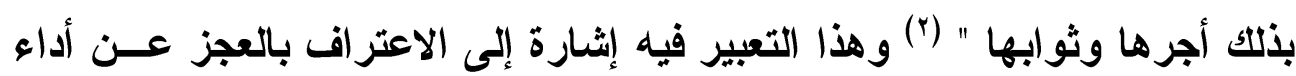

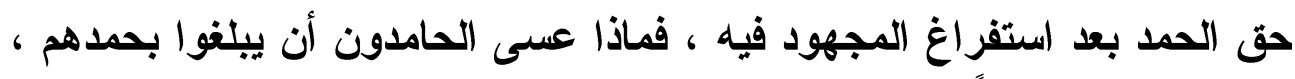

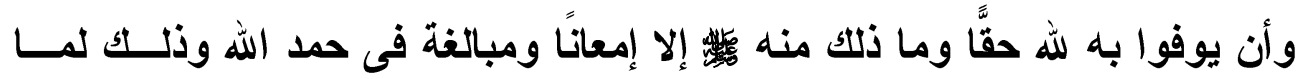

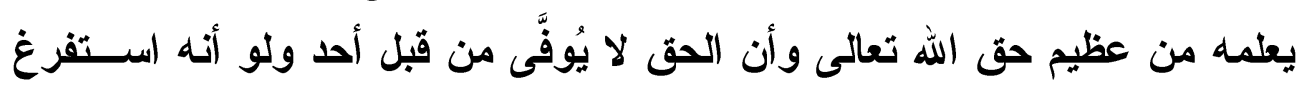

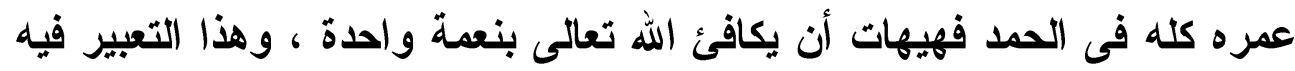

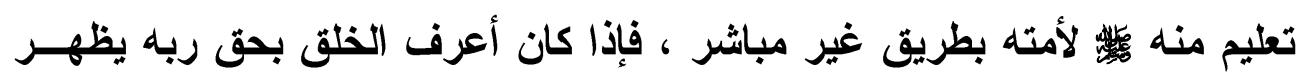

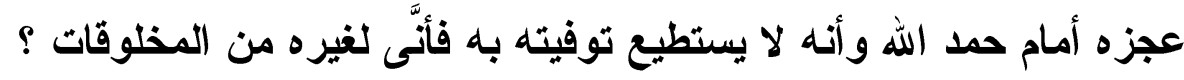

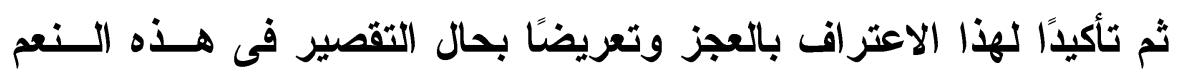

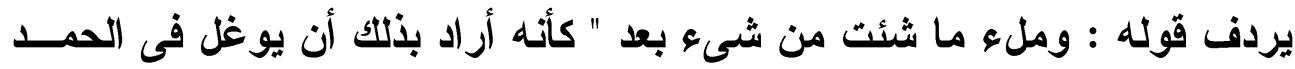

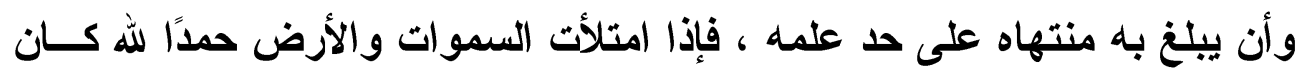

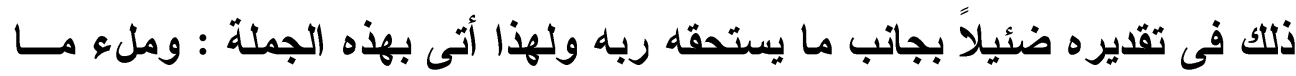

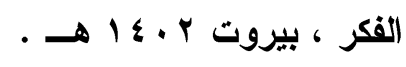

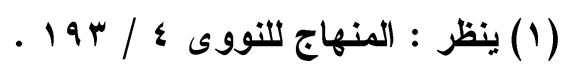

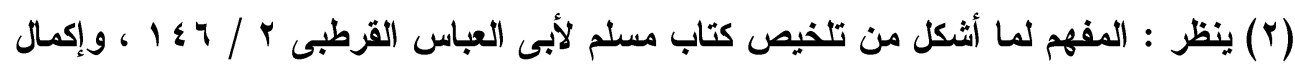

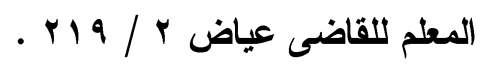


شئت من شىء بعد ، يعنى أن أى شىع تثاؤه فإنا نحمدك بملئه ، قال أهل العلم

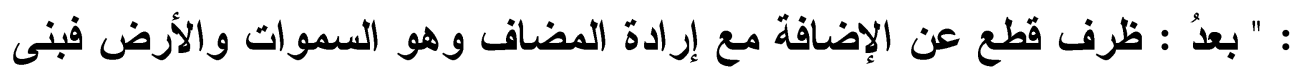

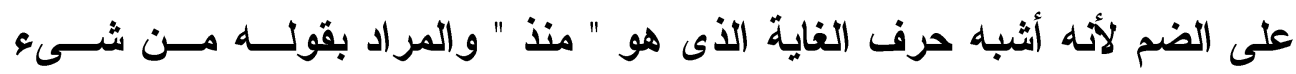

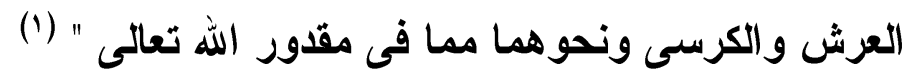

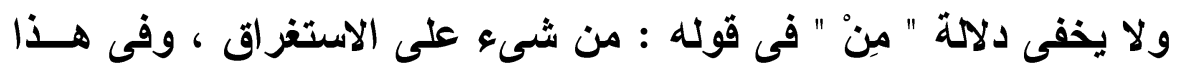

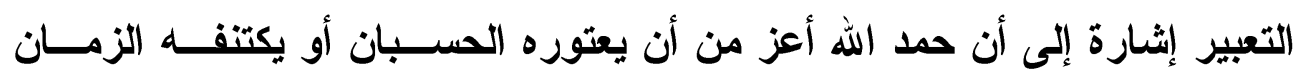

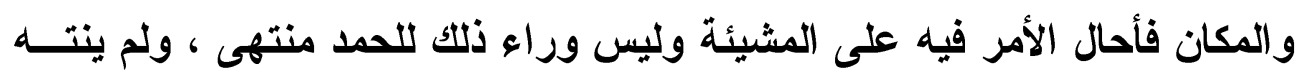

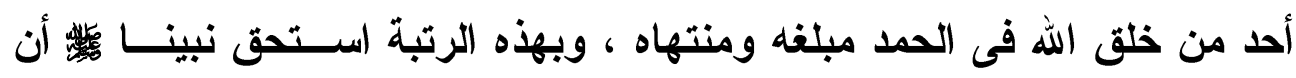

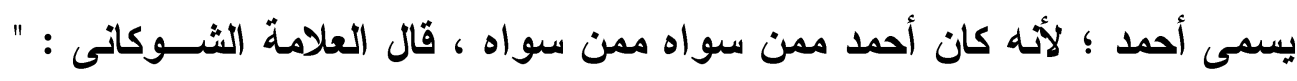

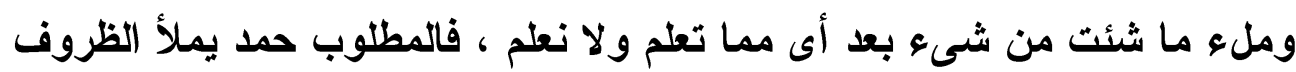

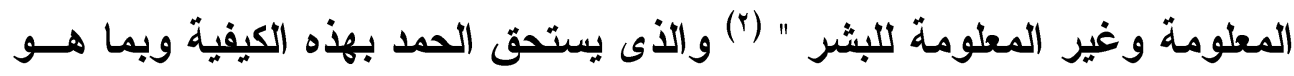

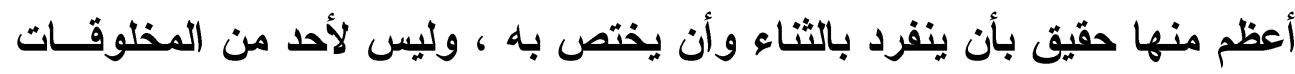

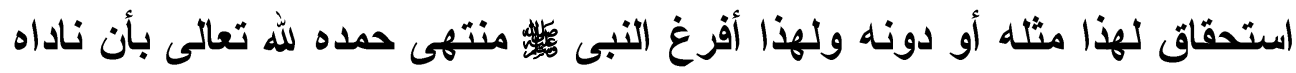

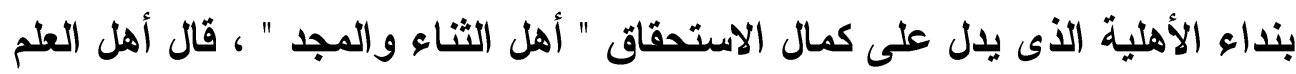

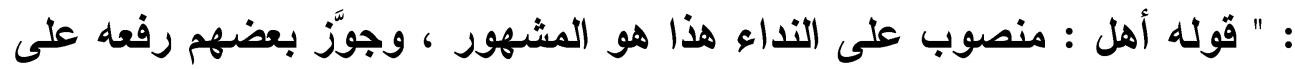

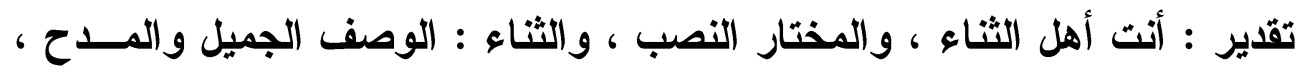

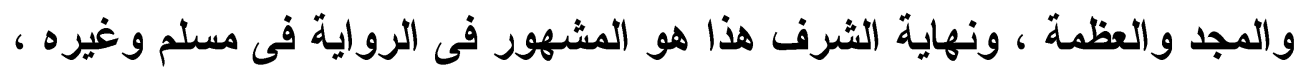

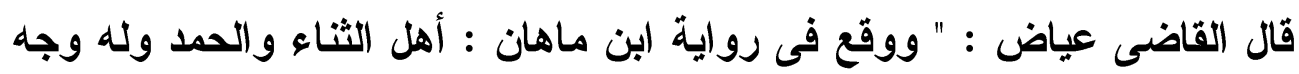

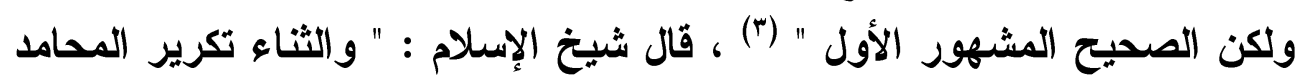

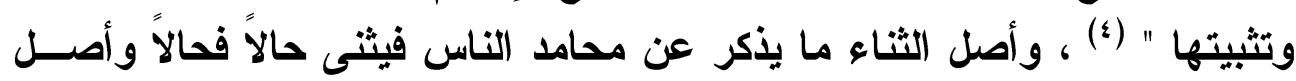

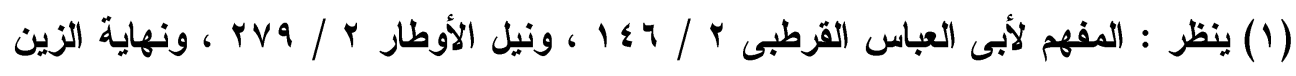

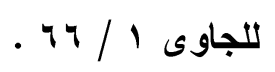

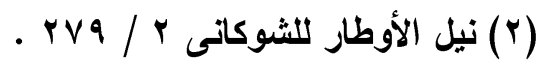

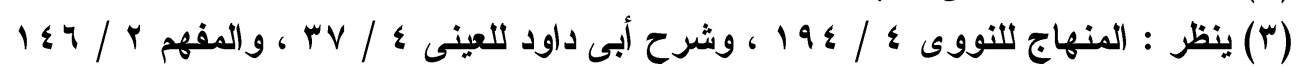

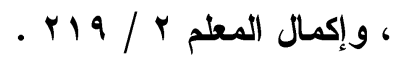

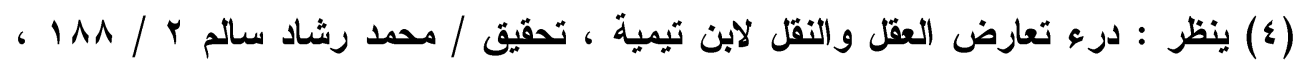

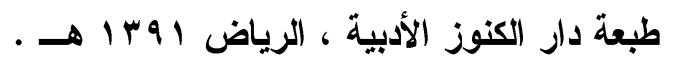


الثثى العطف ومنه الاثنان لعطف أحدهما على الآخر " (') ، وقد فرق أبــو هــلال

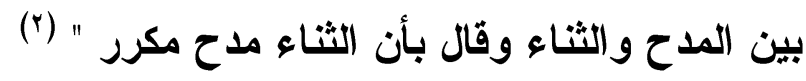

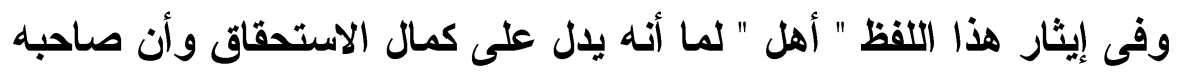

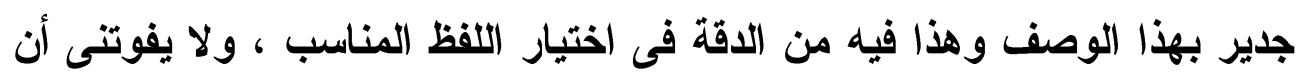

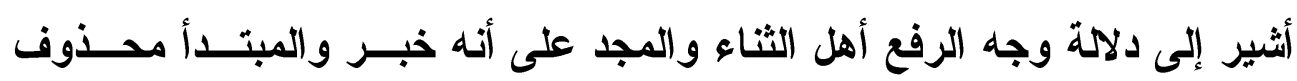

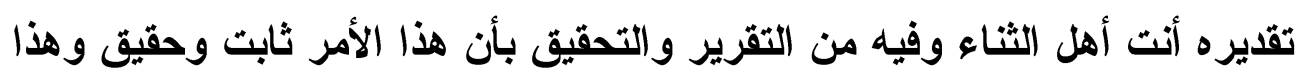

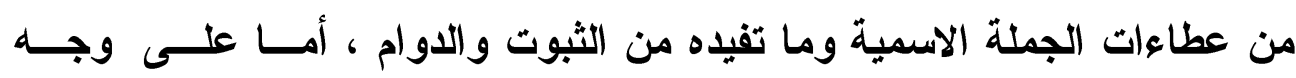

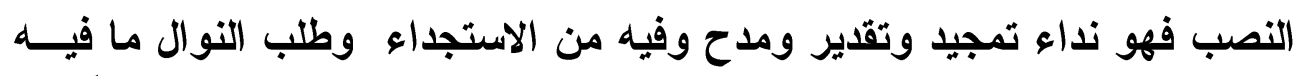

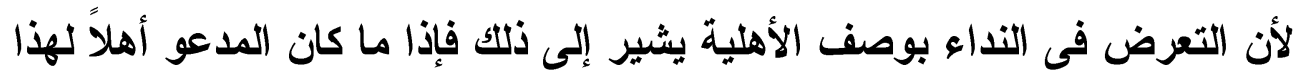

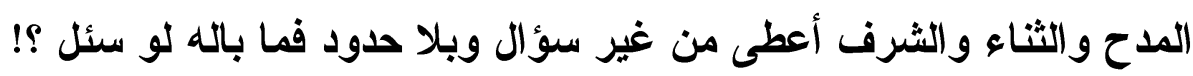

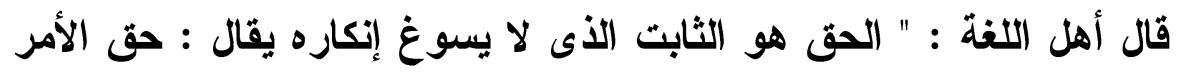

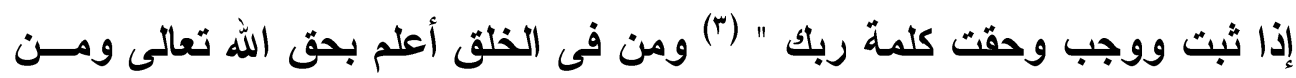

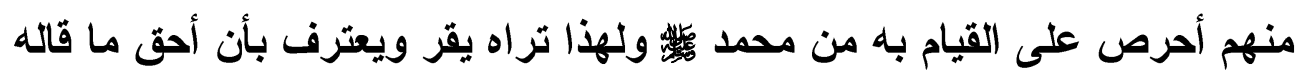

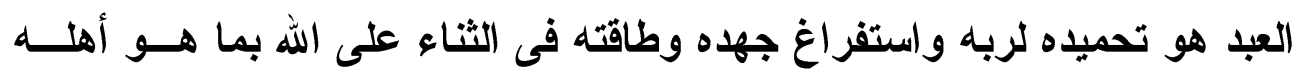

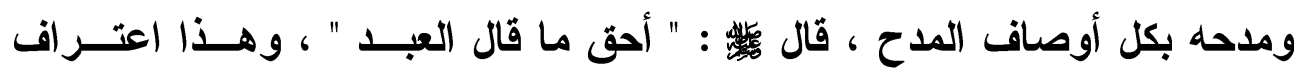

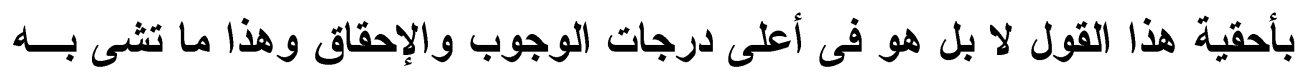

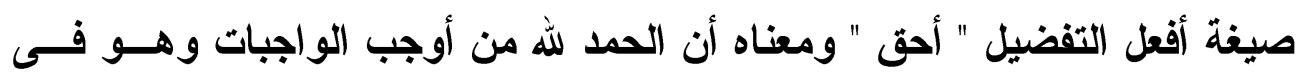

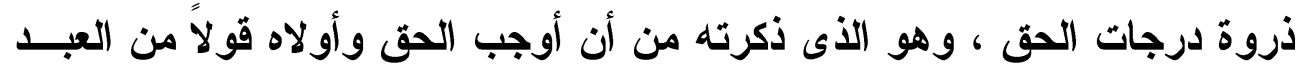

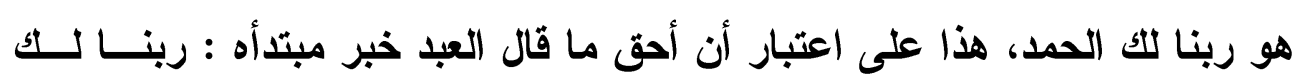

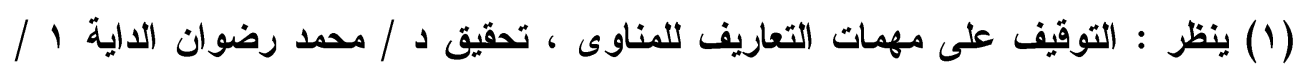

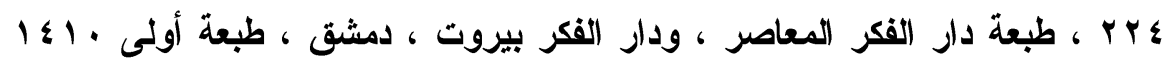

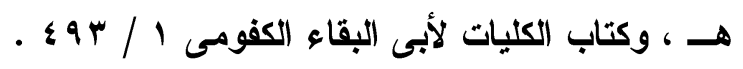

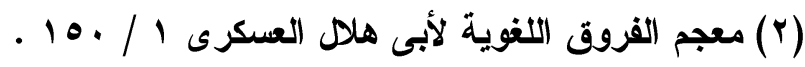

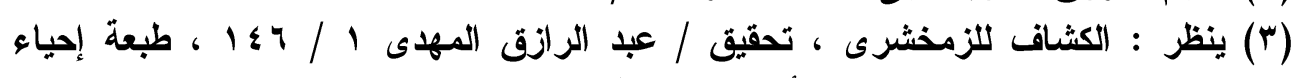

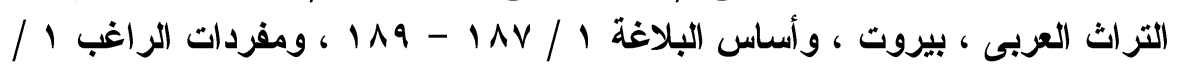

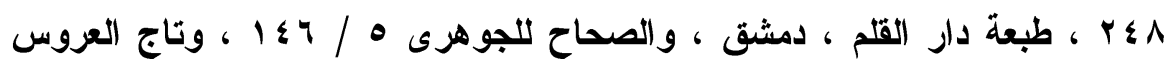


الحمد وهناتك للعلماء رأى آخر هو الأولى بالاعتبار من هذا الوجه وهو أن يكون

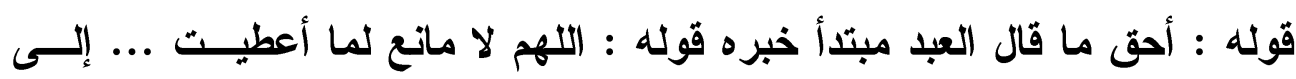

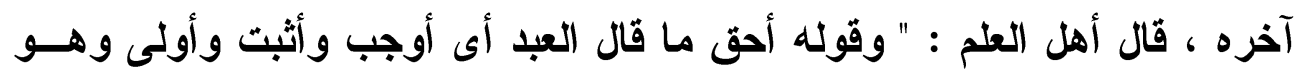

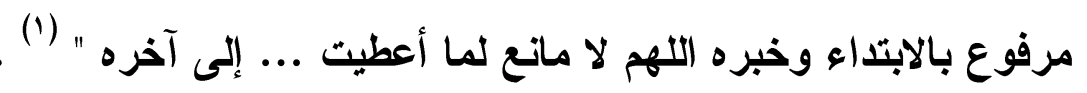

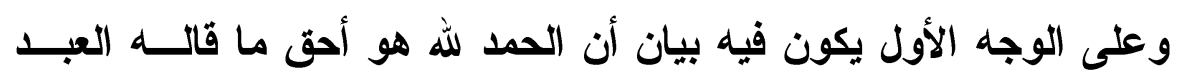

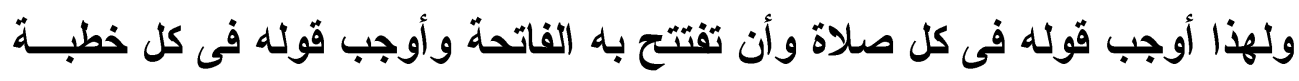

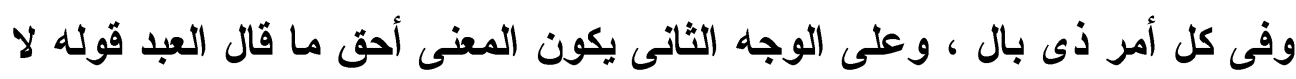

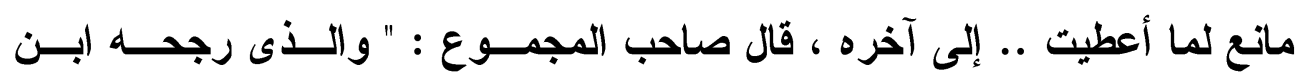

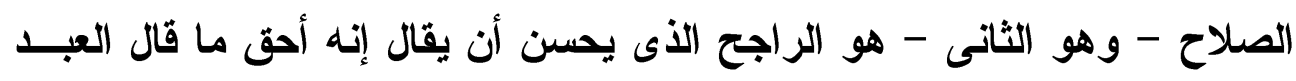

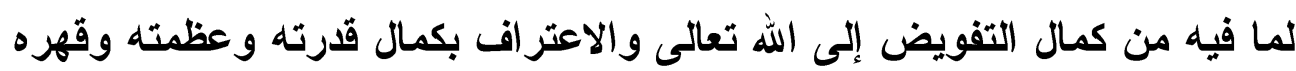

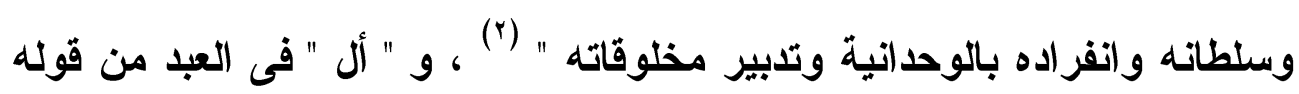

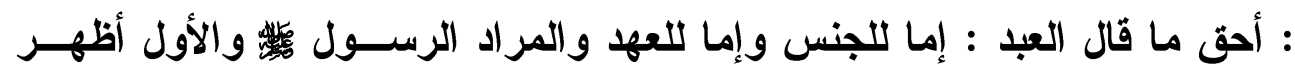

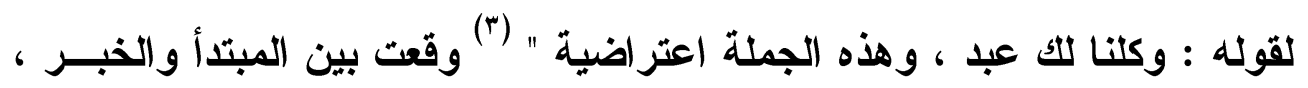

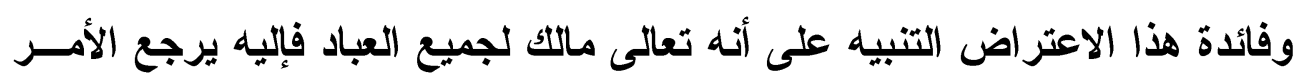

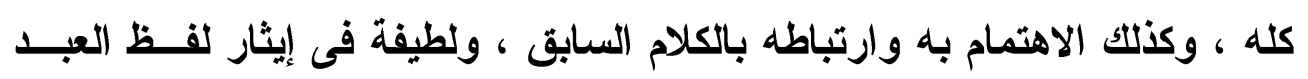

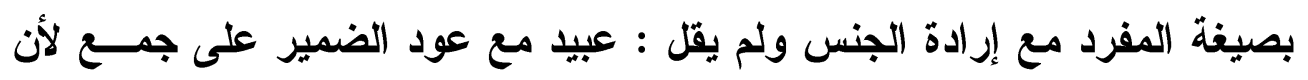

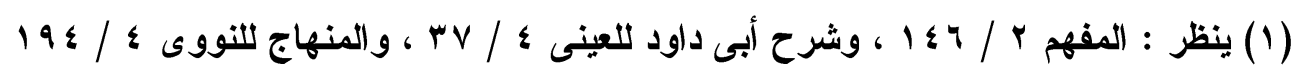
.190،

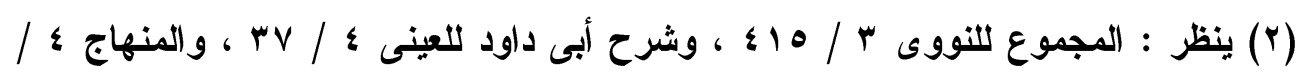

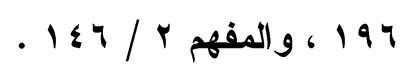

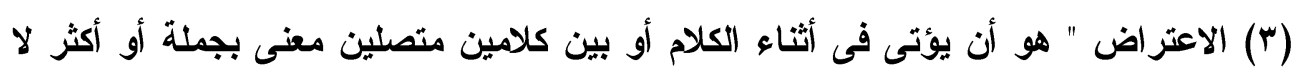

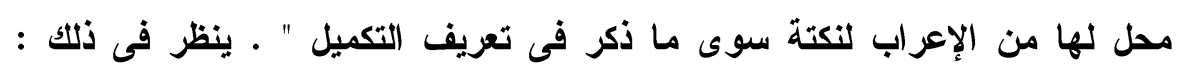

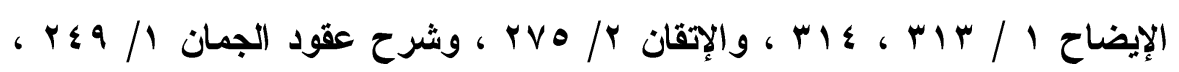

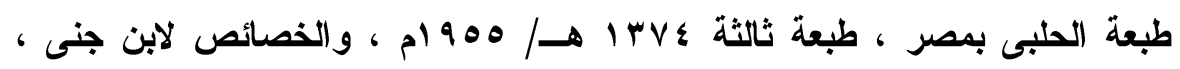

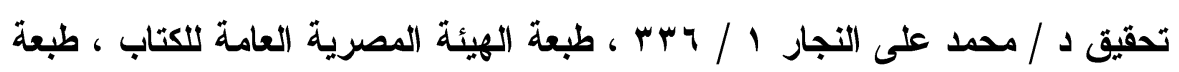
رابعة 1999 مـ ـ محثر 


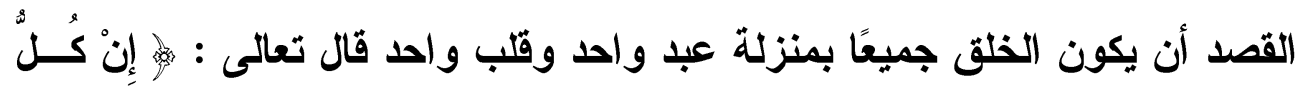

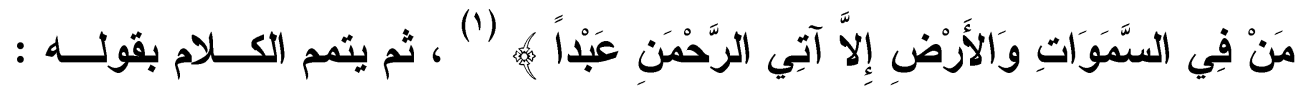

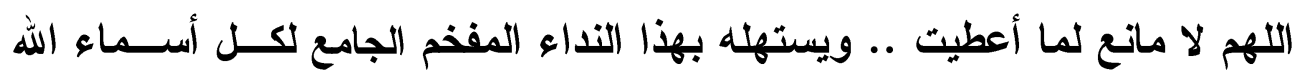

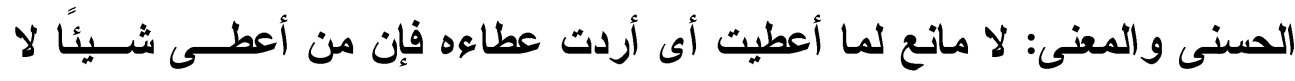

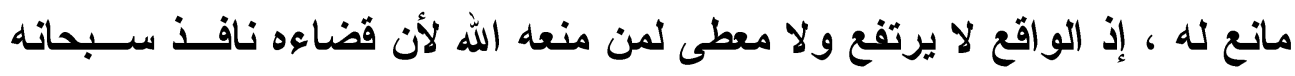

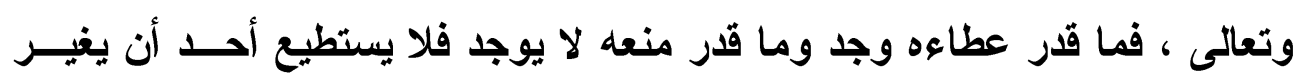

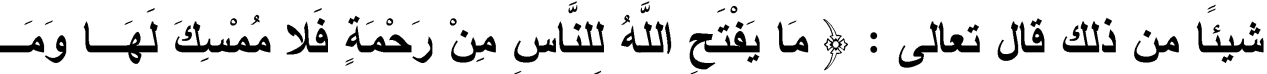

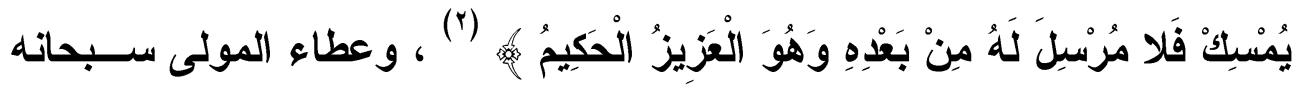

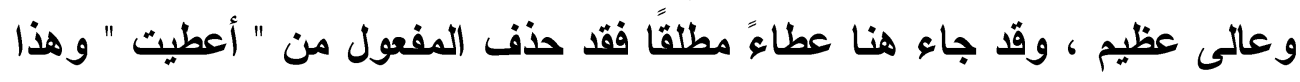

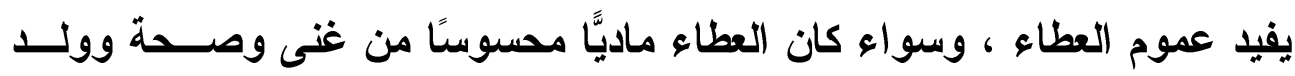

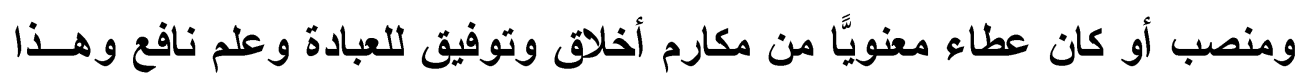

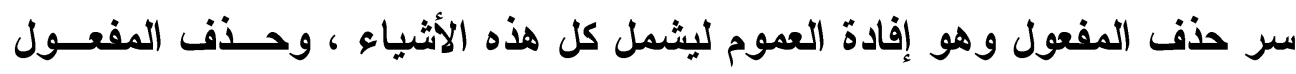

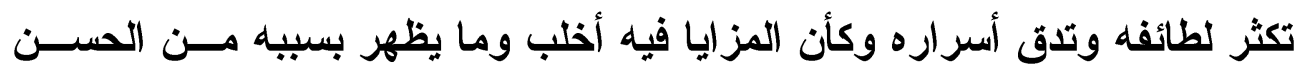

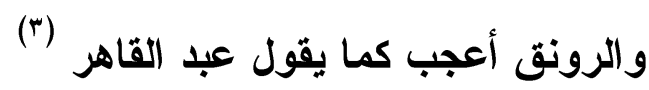

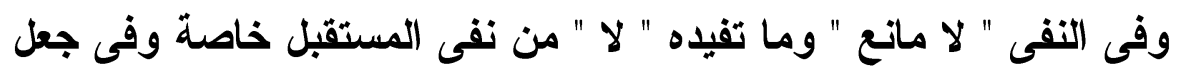

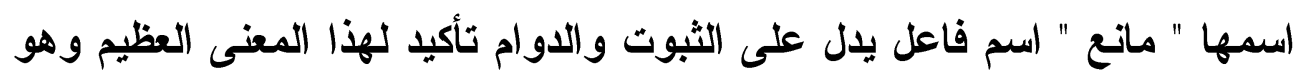

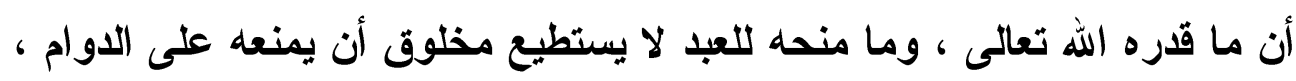

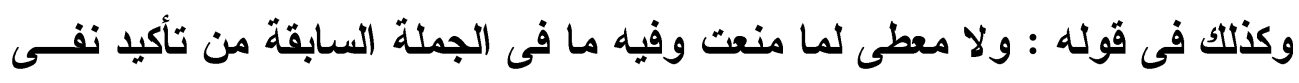

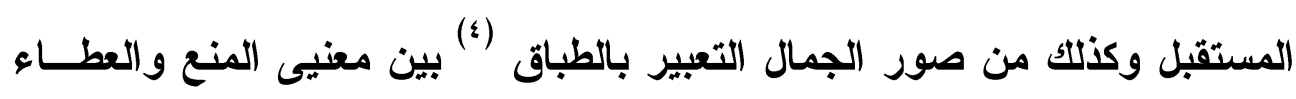

$$
\begin{aligned}
& \text { (1) سورة مريم : الآية بهو . }
\end{aligned}
$$

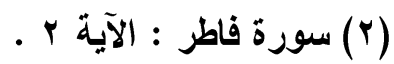

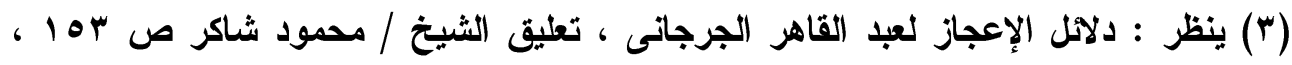

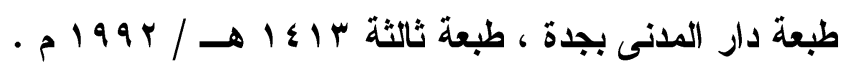

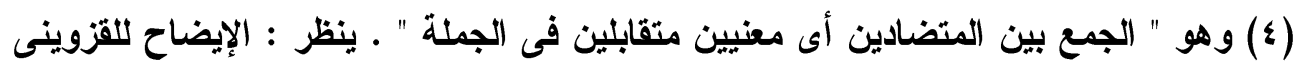


والأى بدوره يبرز شمول وقيمة العطاء بمقارنتها بصورة انعدام المنع ونفيه عن كل أحد ، وهذا ما يفهم من معنى " لا " النافية للجنس لأن المعنى ليس لأحد كائنًا

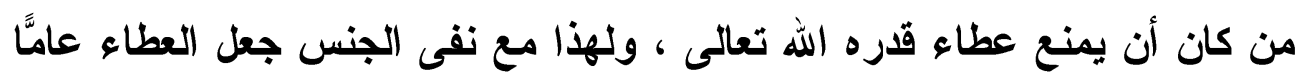

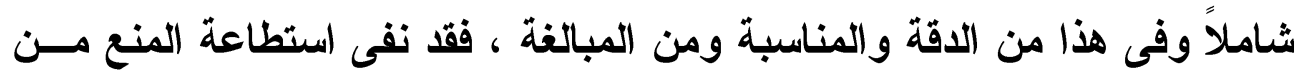

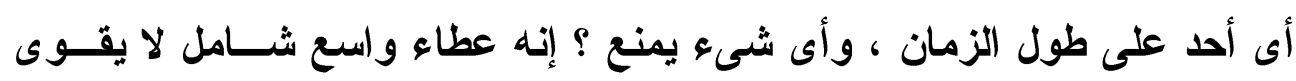

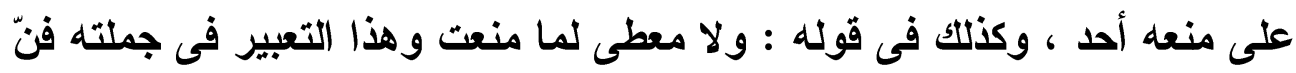

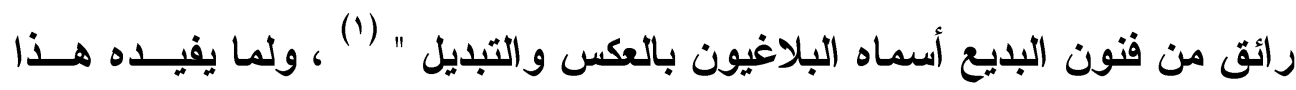

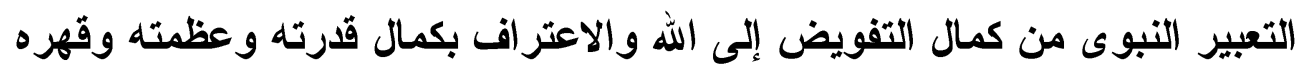

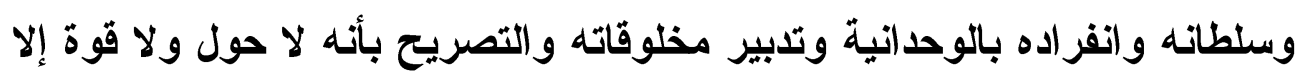

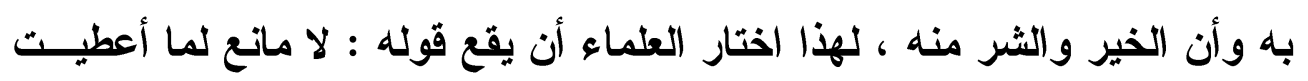

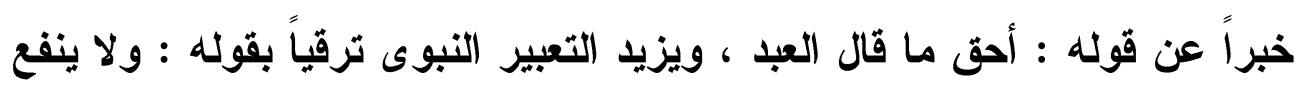

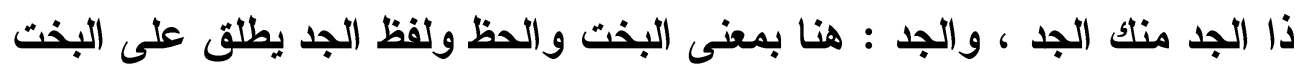

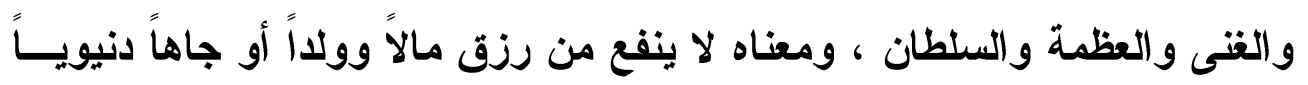

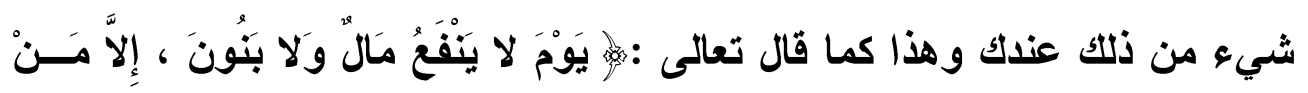

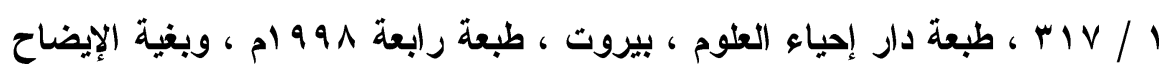

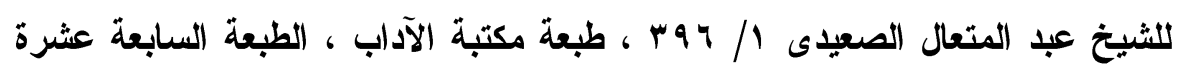

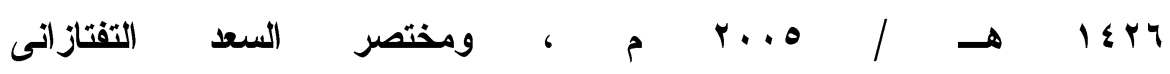

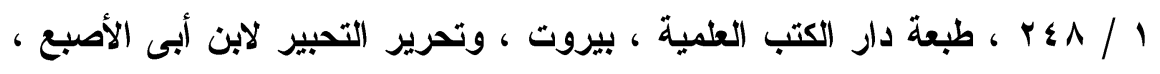

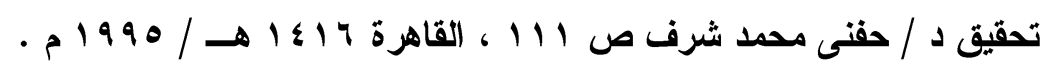

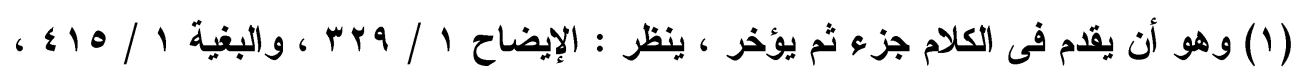

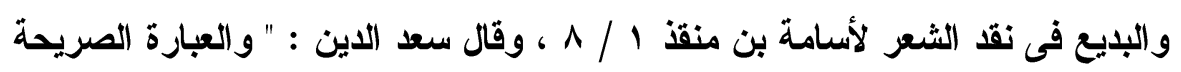

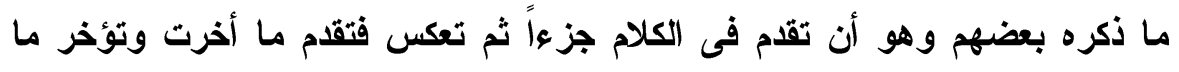

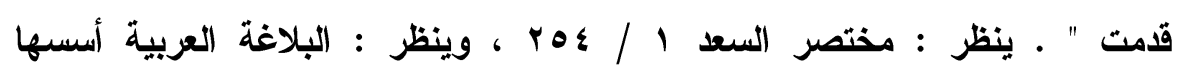

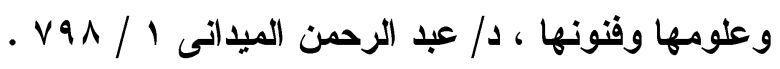




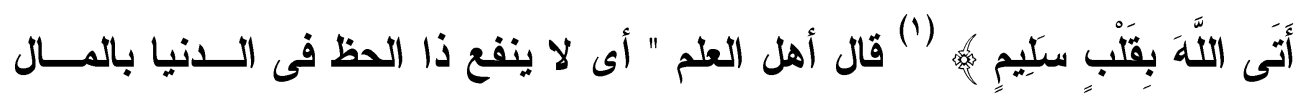
و الولا والعظمة والسلطان منتك حظه أى لا ينجيه حظه منك ، وإنما ينفعه وينجيه

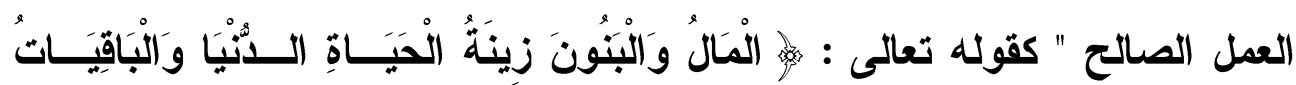

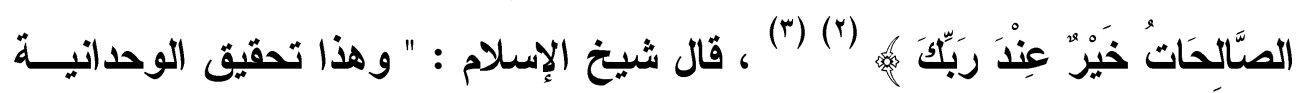

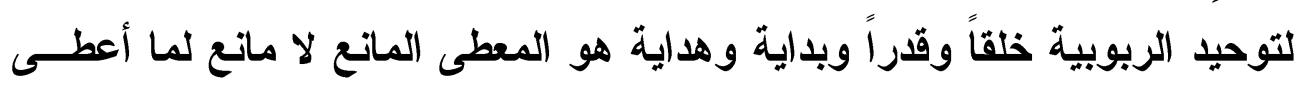

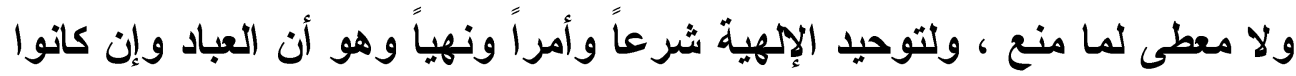
يعطون ملكاً وعظمة وبختاً ورياسة فى الظاهر أو فى الباطن كأصحاب المكاثفات

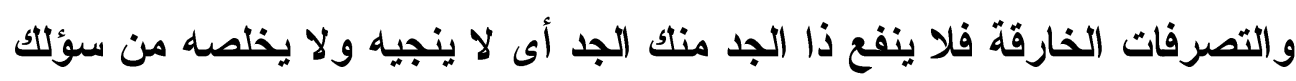
وحسابك حظه وعظمته وغناه ولهذا قال : " منكك " ولم يقل ينفعه عندك فإنه لــو

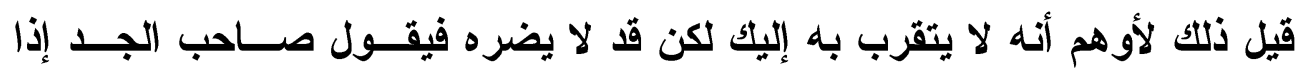

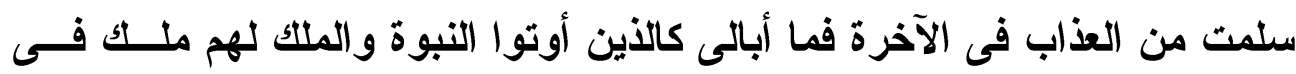

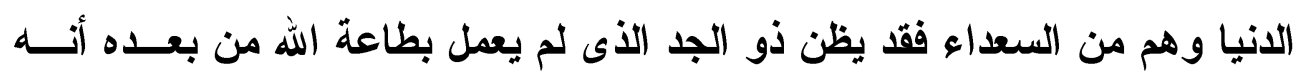
كان كذلك فقال : " ولا ينفع ذا الجد منك ، ضَمَنَ ينفع معنى ينجى ويخلص فبـين أن جده لا ينجيه من العذاب بل يستحق بذنوبه ما يستحقه أمثاله ولا ينفعه جــــ لهاه

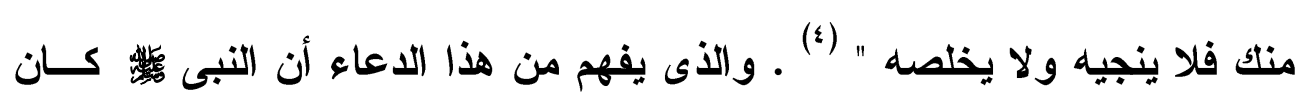
يجمع فى دعائه بين الحمد الذى هو رأس الثكر وبين التوحيد والاستغفار ، وهذا

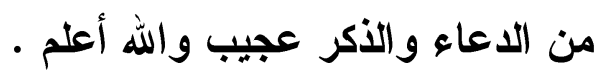

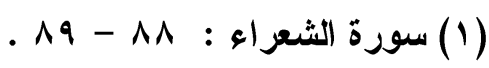

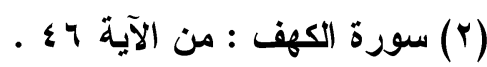

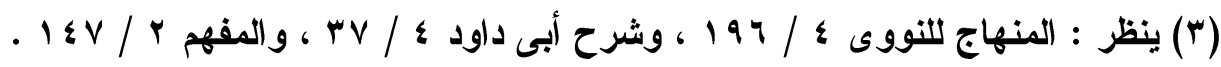

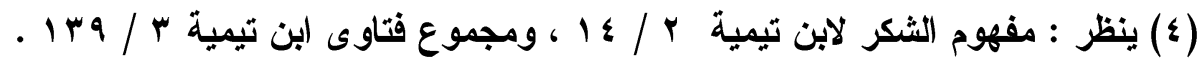




\section{الابحث الرابع \\ ها يقال من الدوعاد فى السجود}

الدواء الأول :

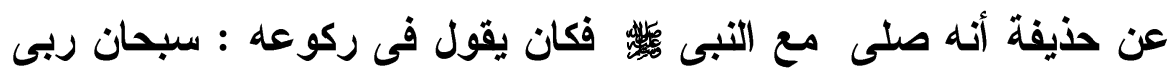
العظيم وفى سجوده : سبحان ربى الأعلى ، وما مر بآية رحمة إلا وقف فسأل ولا

بآية عذاب إلا وقف عندها فتعوذ " (1)

مضى بنا فى مبحث سابق من أدعية الركوع قوله

العظيم " وقد ذكرت فى معنى التسبيح ومعنى الرب ما يغنى عن ذكره هنا وقلت كما قرر العلماء - التسبيح هو التتزيه والتقديس ، و " سبحان " علــم للتســبيح

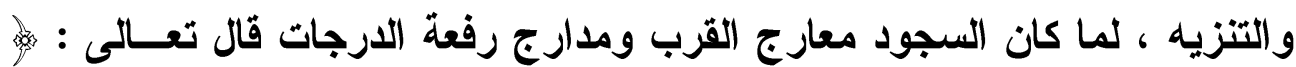

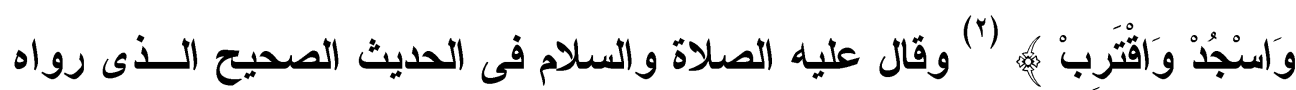

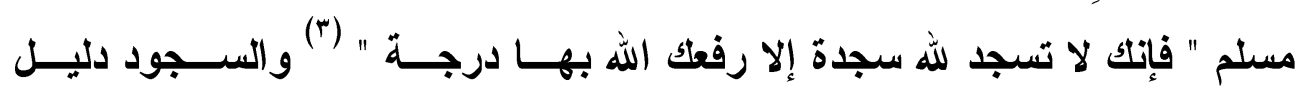

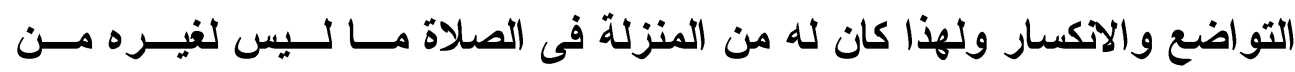
الأركان وكان من الحكم اللطيفة أن شرع الله تعالى لعباده أن يقولوا فى سجودهم

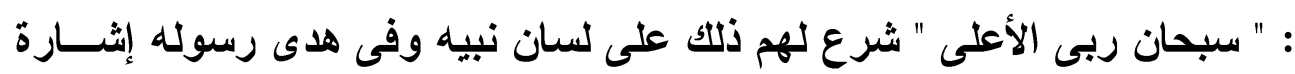

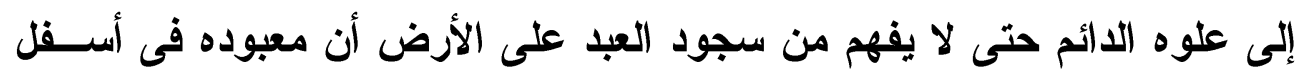

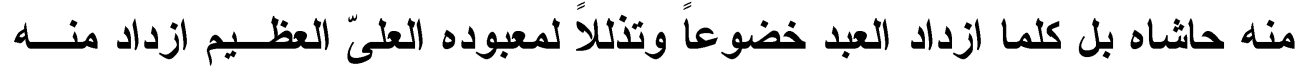
قرباً معنوياً ومعية خاصة تخص خواص عباده المؤمنين وفى هذا يقول رســول

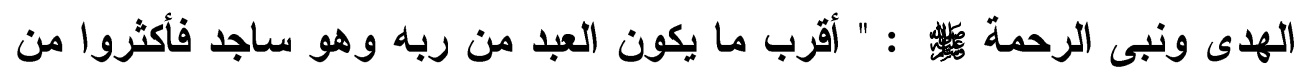
الدعاء " (๕) ومعنى كون العبد أقرب إلى الله حالة السجود من بين سائر أحوالــه.

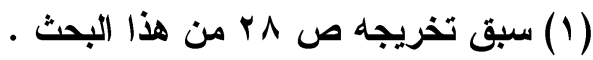

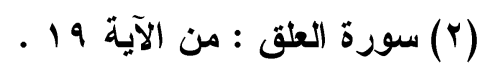

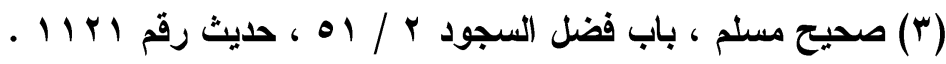

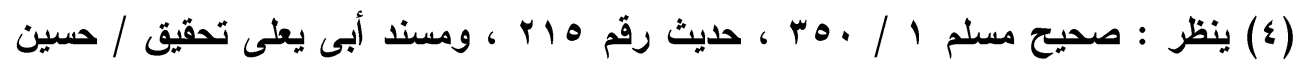

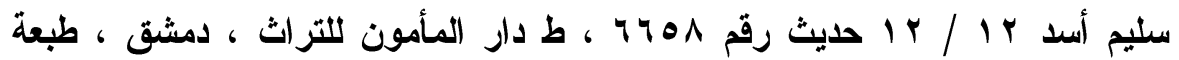




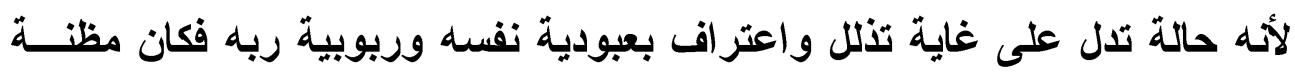

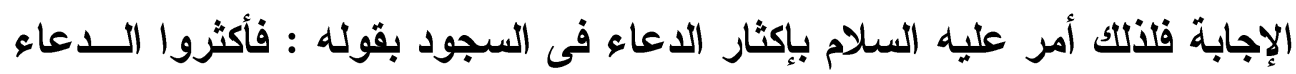
هو

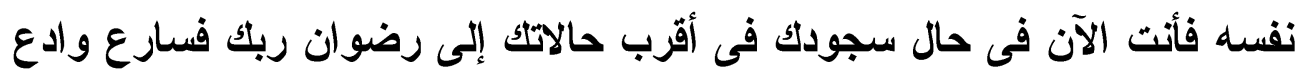

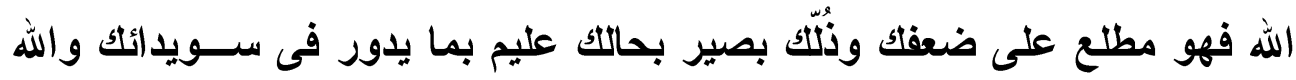

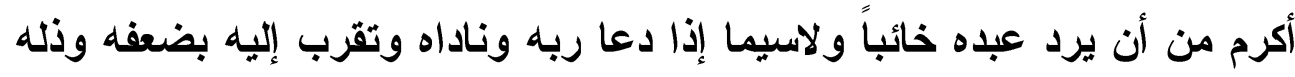

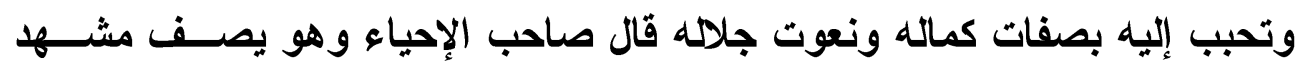

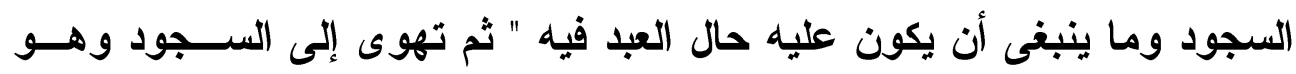

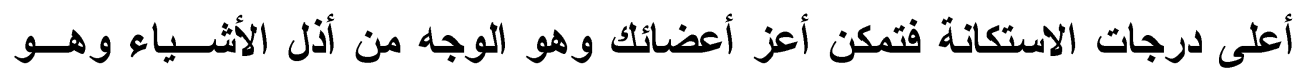

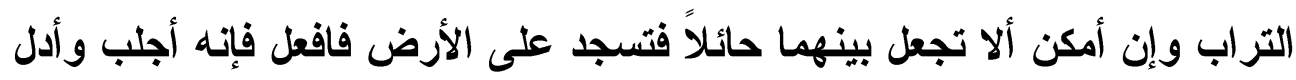

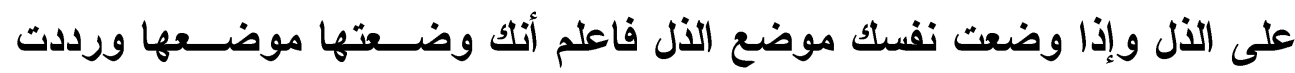

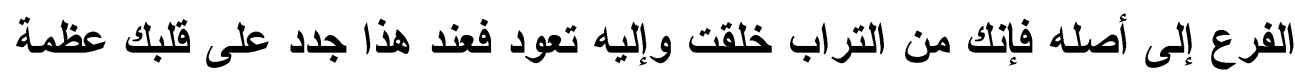

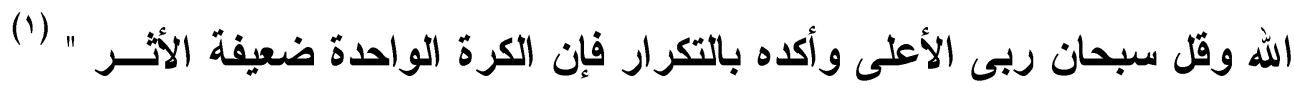

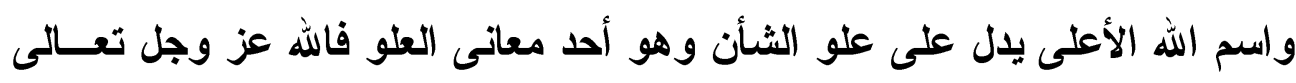

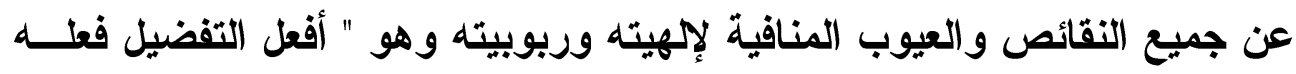

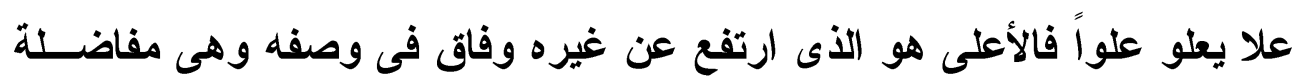

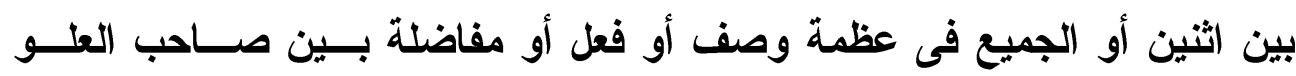

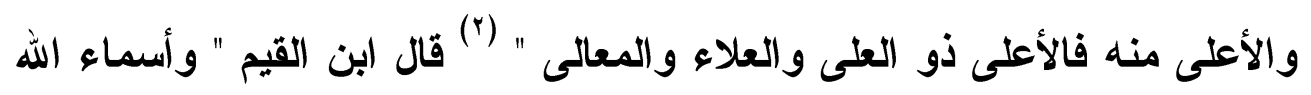

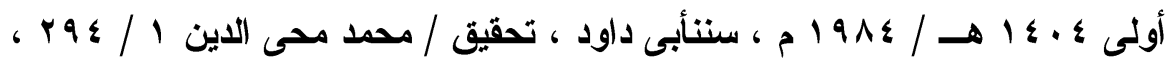

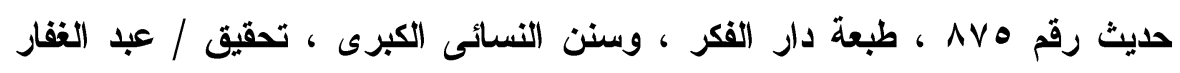

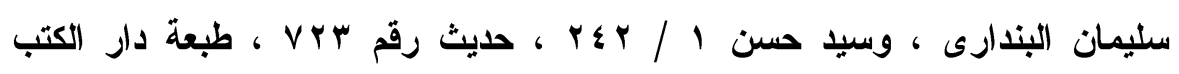

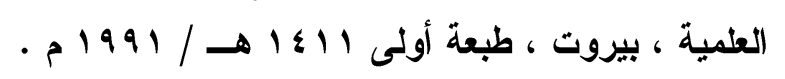

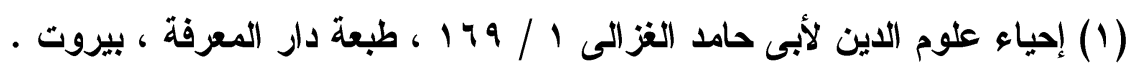

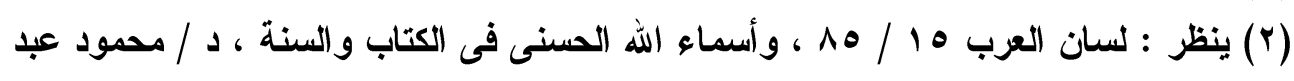

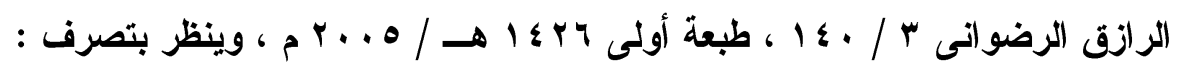


الحسنى وصفاته العليا هى موضع الحمد ومن تمام حمده تسبيحه وتنزيهه عمــا

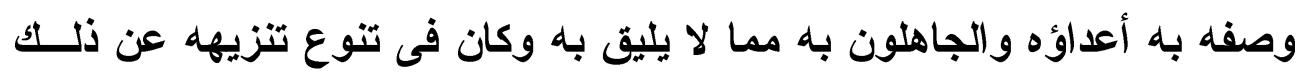

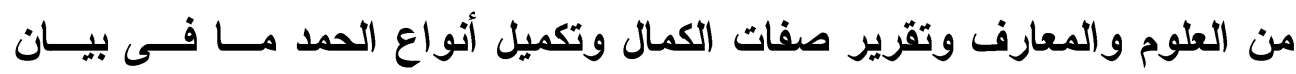

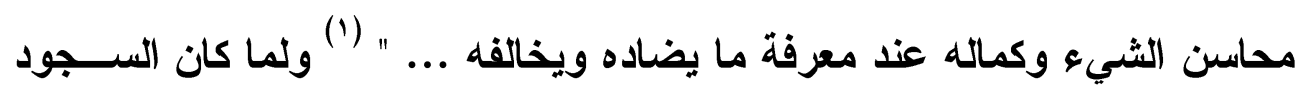

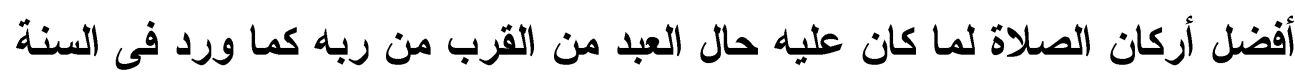

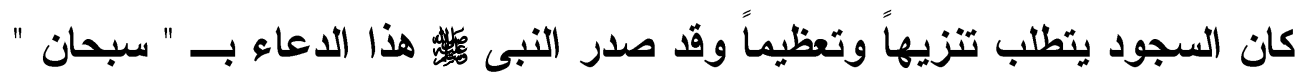

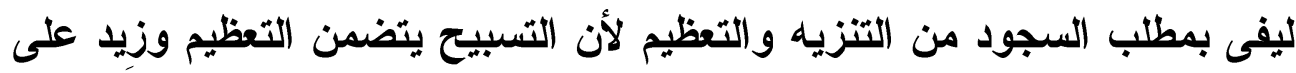

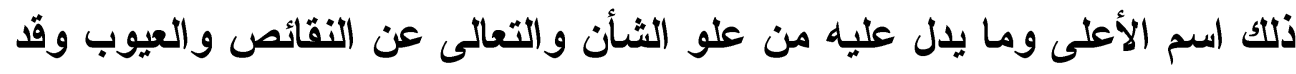

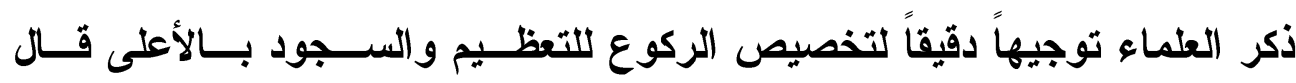

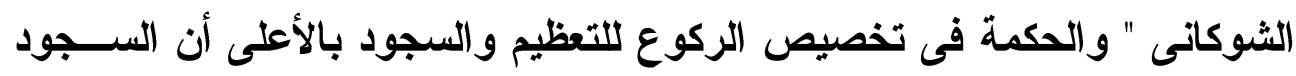

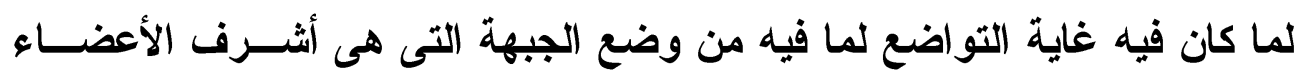

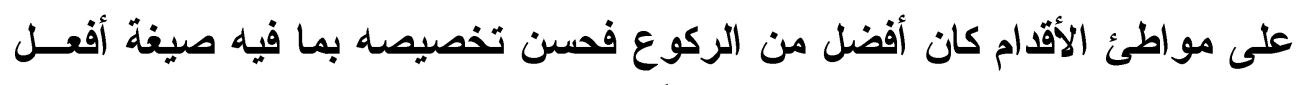

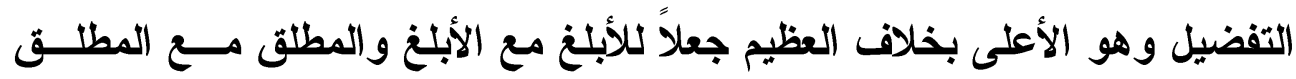

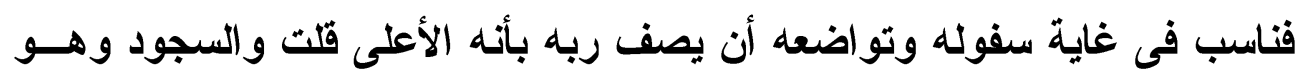

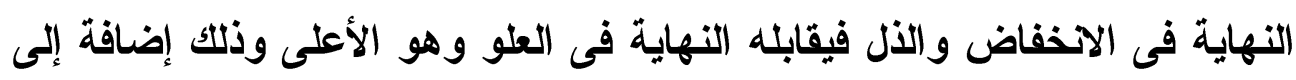

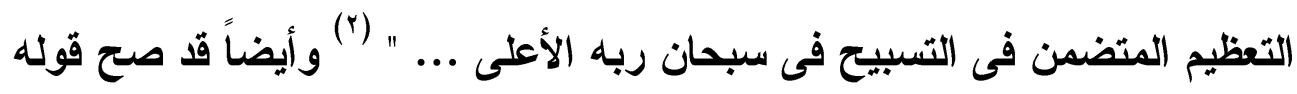

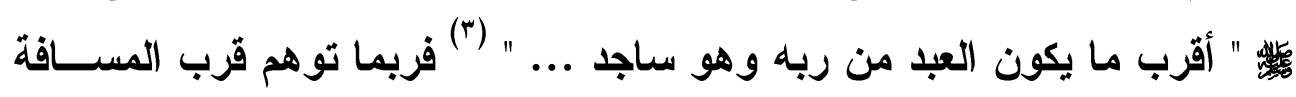

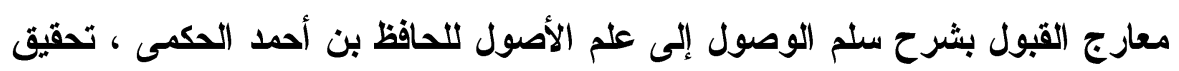

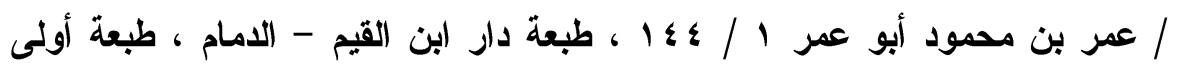

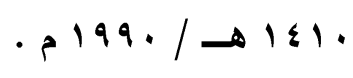

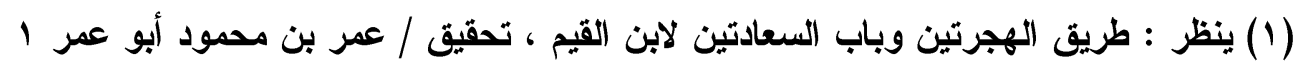

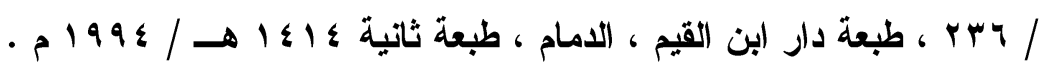

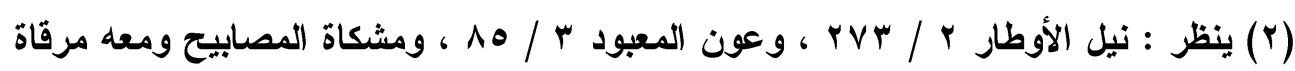

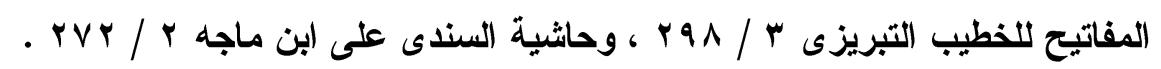

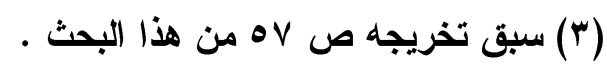


فندب سبحان ربى الأعلى دفعا لذلك التوهم وأيضاً فى السجود غاية انحطاط مـن

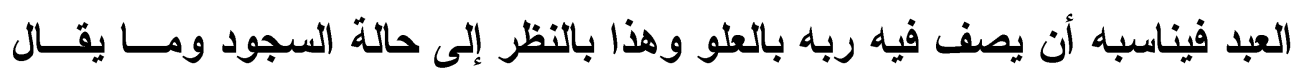

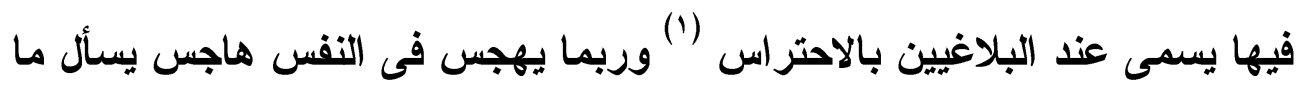
الحاجة إلى التنزيه ونفى العيوب والله تعالى ليس بمظنة للعيوب أبداً بل بعده عنها لهاجئ

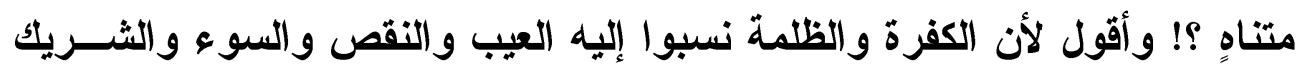

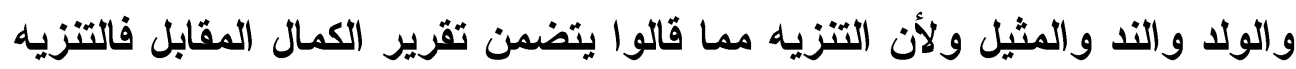

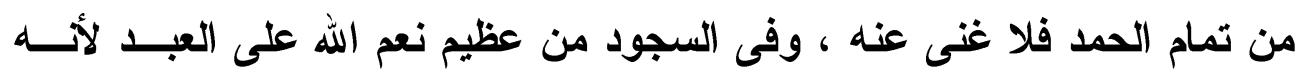

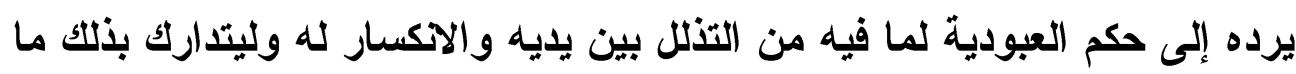

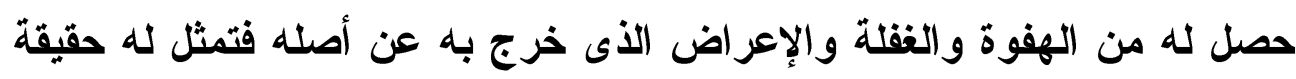

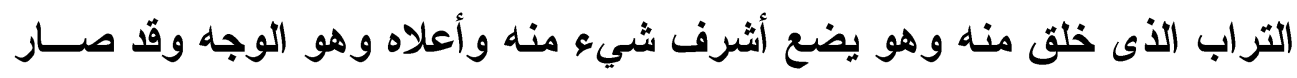

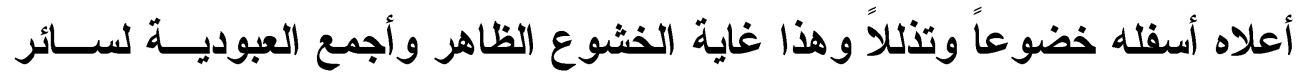

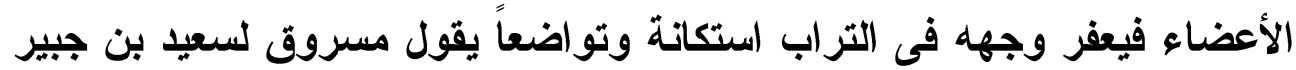

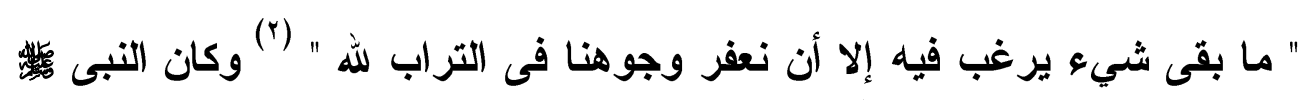

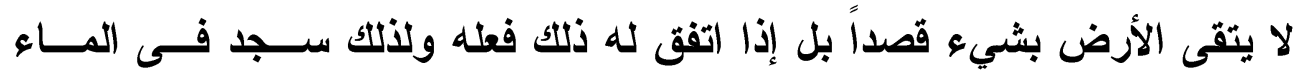

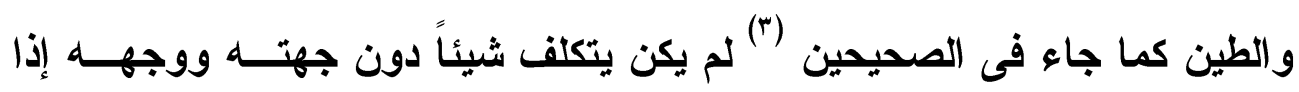

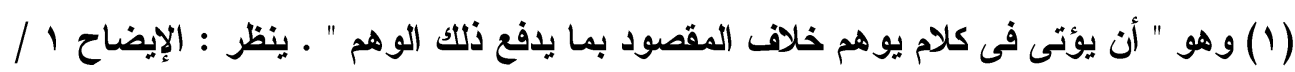

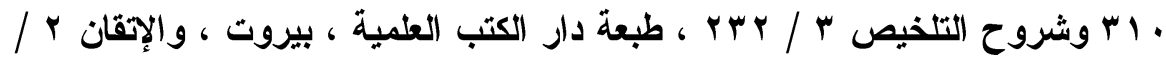

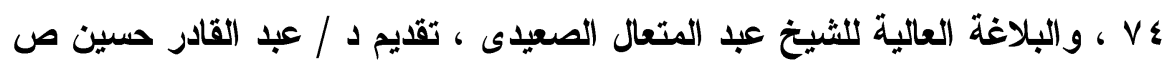

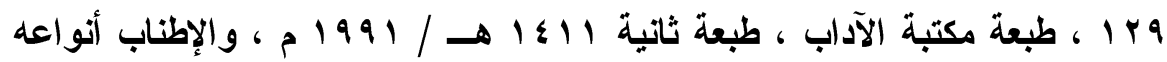

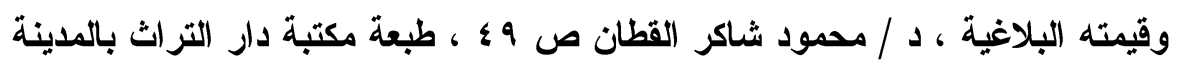

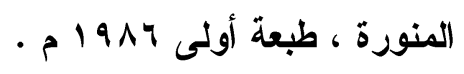

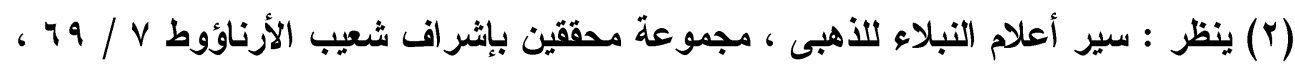

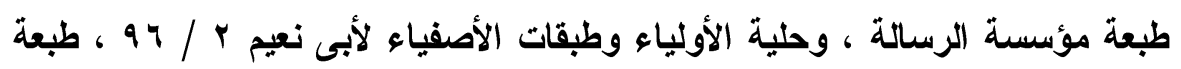

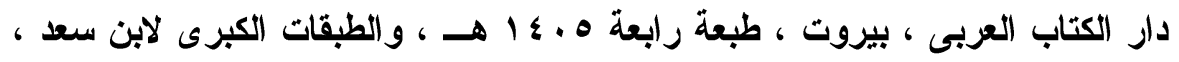

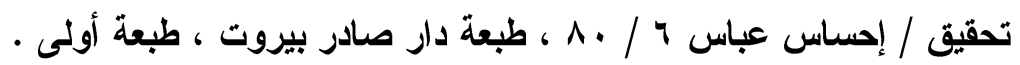

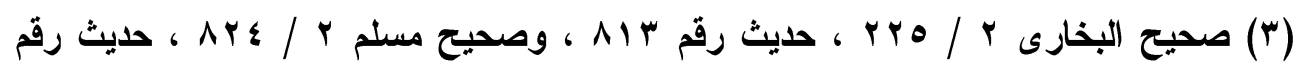




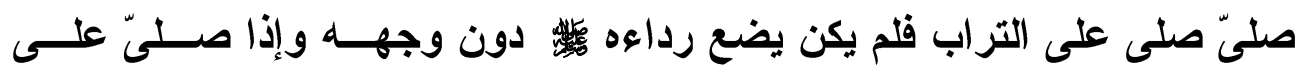

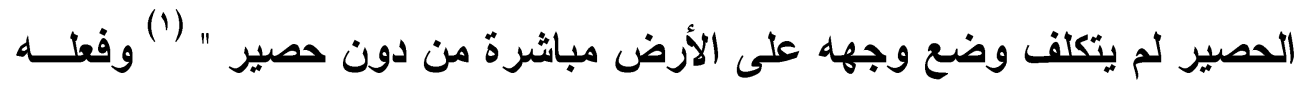

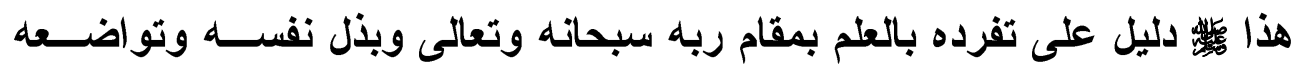
لربه وفى هذا من التعليم لأمته ما فيه ، والله تعالى أعلى وأعلم .

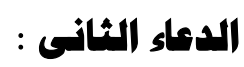

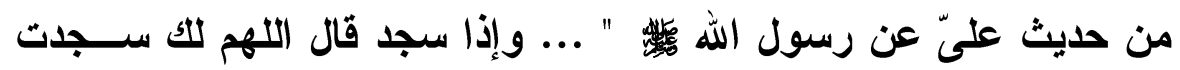
وبك آمنت وللك أسلمت سجد وجهى للأى خلقه وصوره وشــق ســمعه وبصــره تبارك الله أحسن الخالقين " (r) واكن

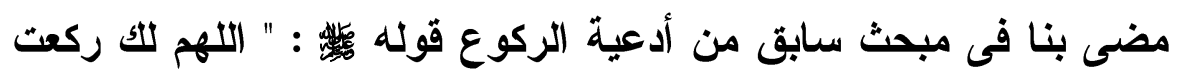

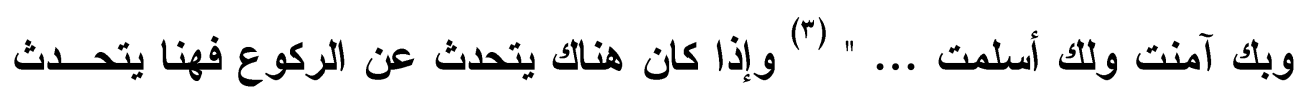
عن السجود والسجود ركن من أركان الصلاة كالركوع وفى كل منهما إعــلان لله ونه

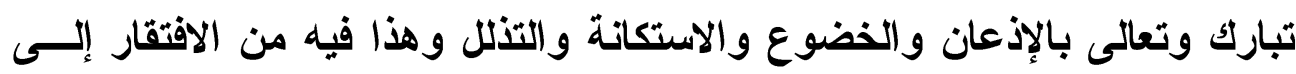

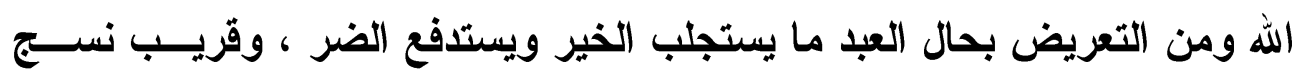

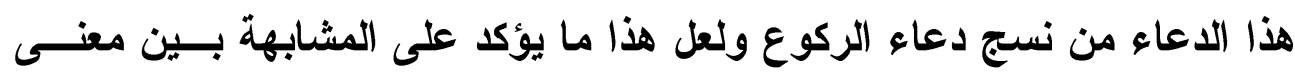

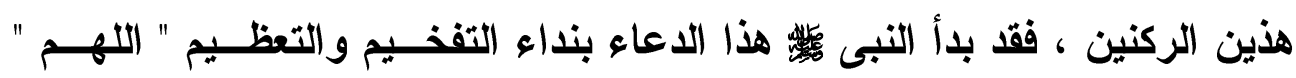

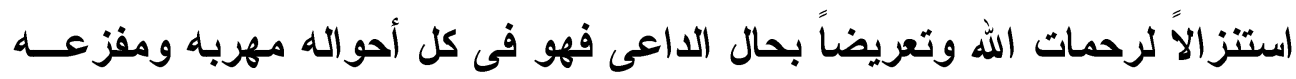

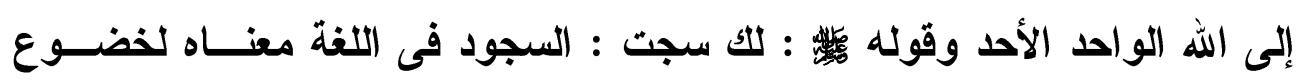

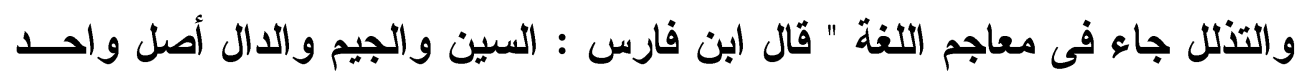

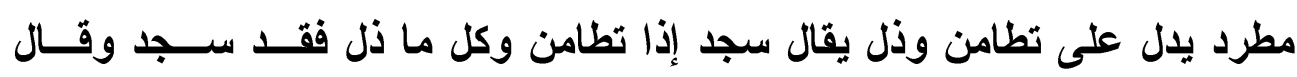

\section{.1178}

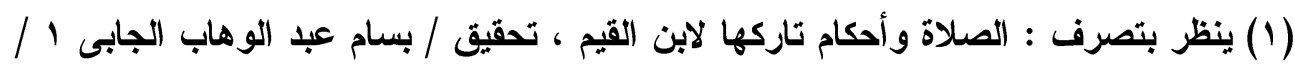

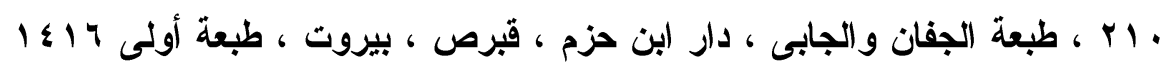

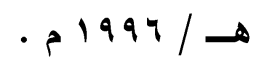

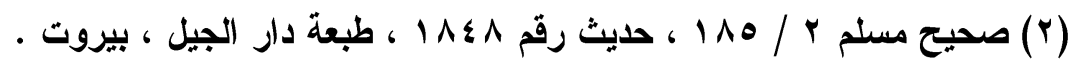

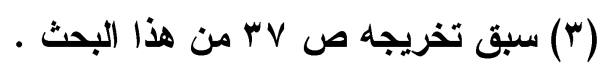


الأزهرى قال الواحدى أصله فى اللفة الخضوع والتذلل قال وسجود كل شيء فى في

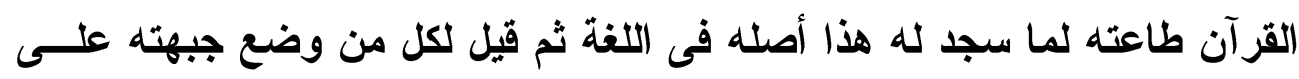
الأرض سجد لأنه غاية الخضوع ، ولا خضوع أعظم منه " ( ).

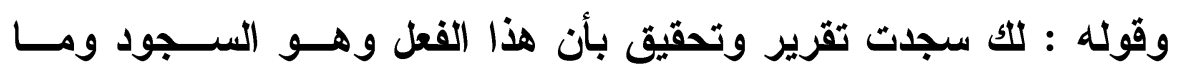

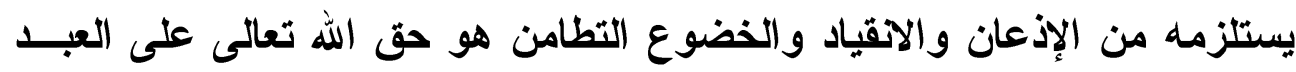

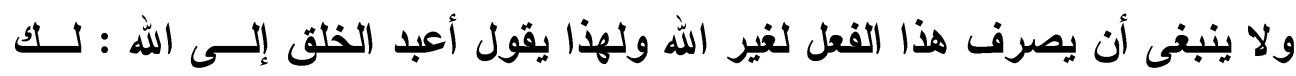

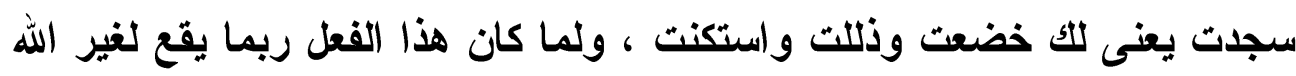

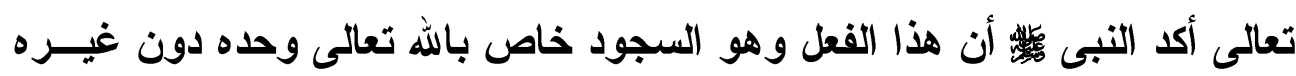

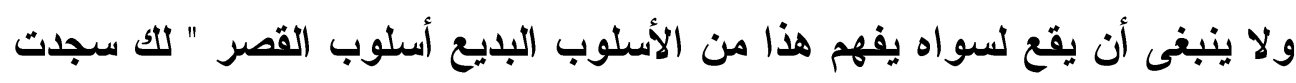

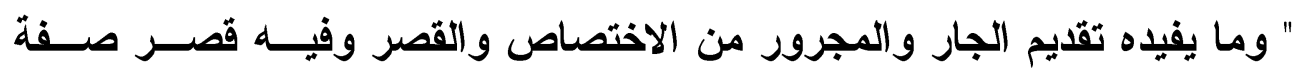

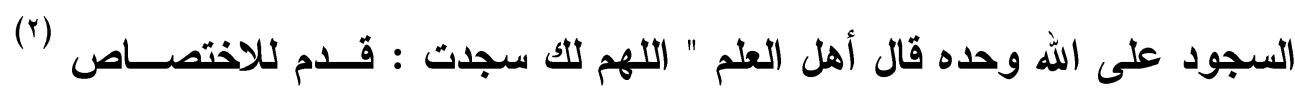

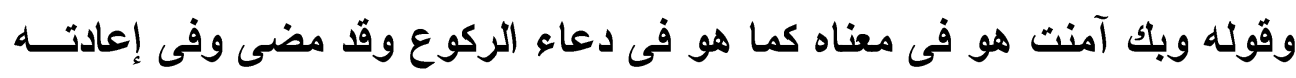

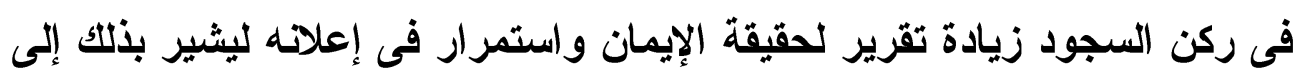

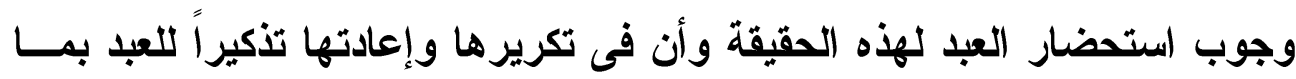

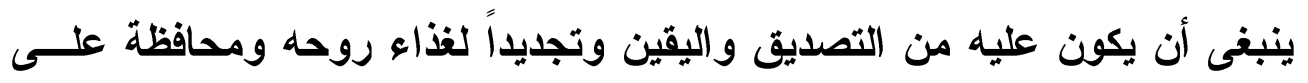

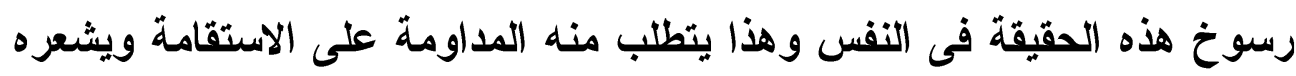

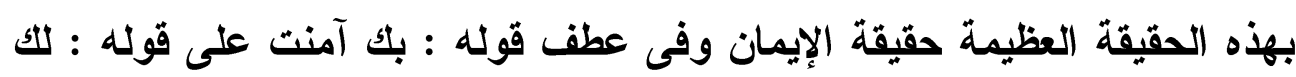

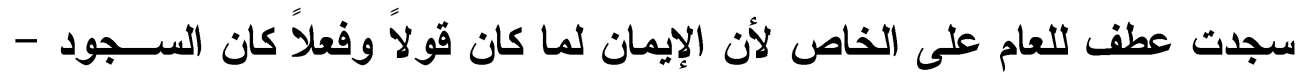

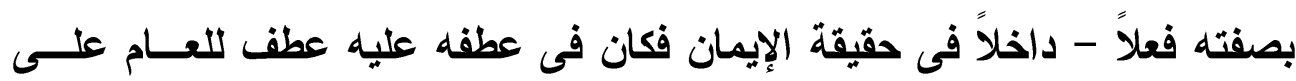

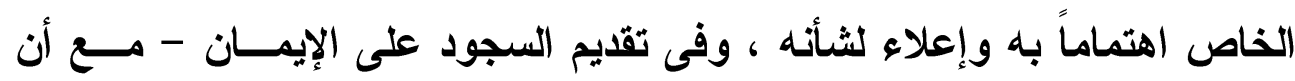

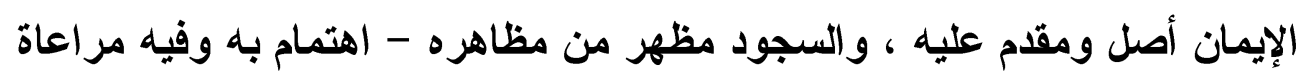

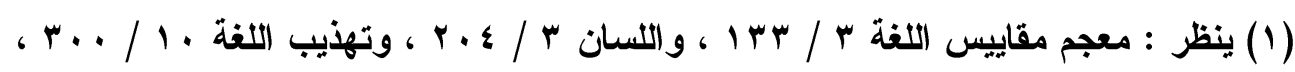

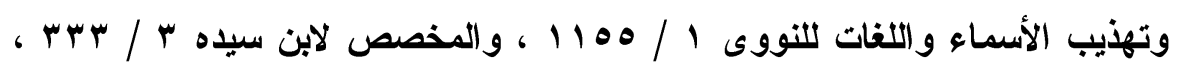

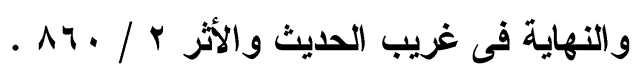

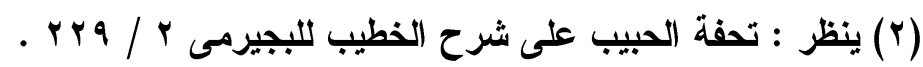


للحالة التى عليها العبد ولهذا بدأ بهه ، وقوله للك أسلمت تأكيد وتقريــر لحقيقــة

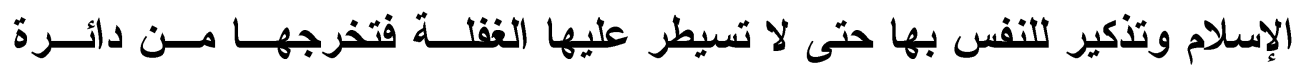

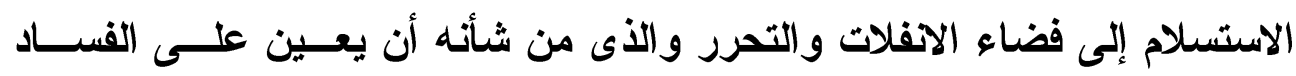

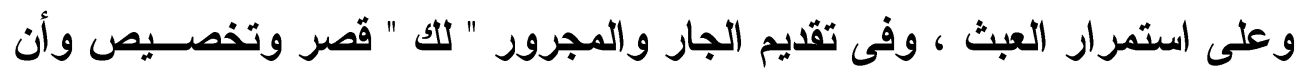

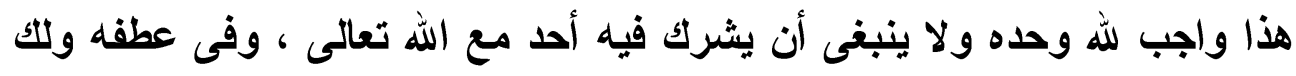

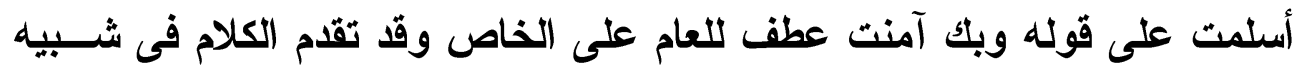

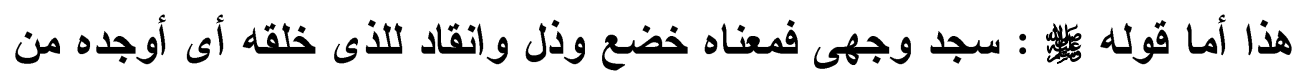

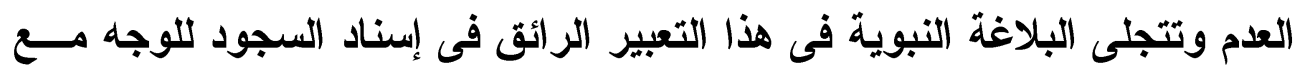

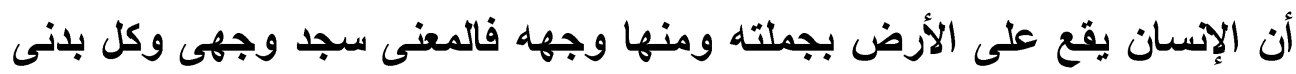

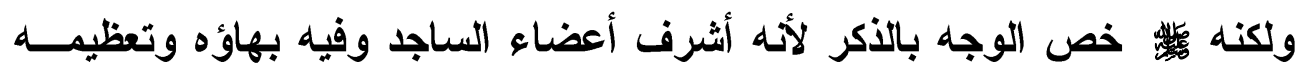

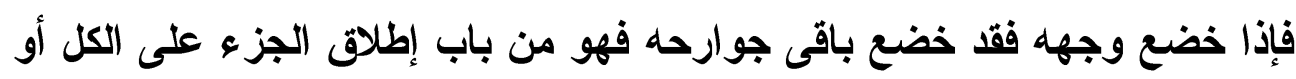

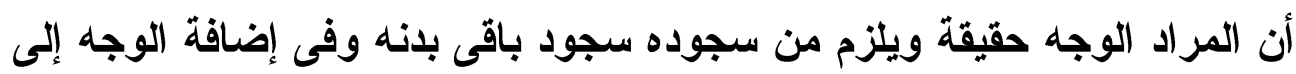

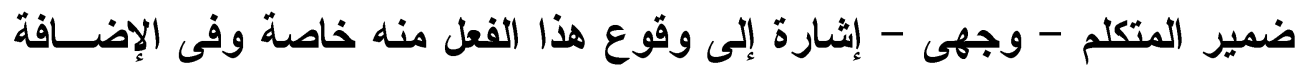

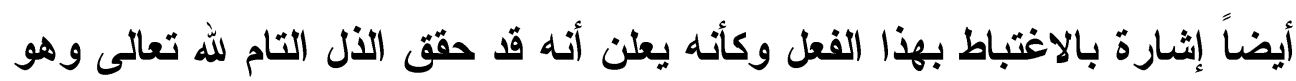

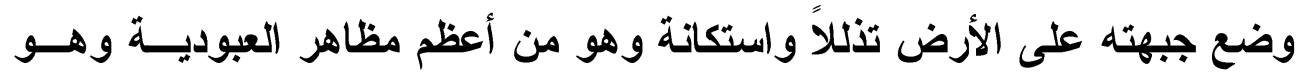

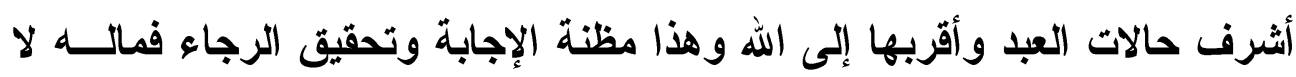

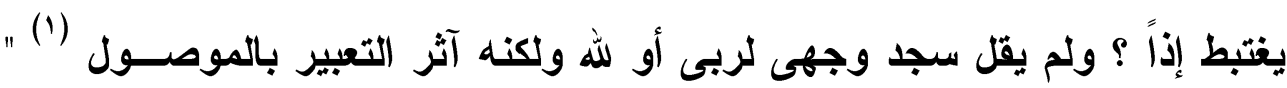

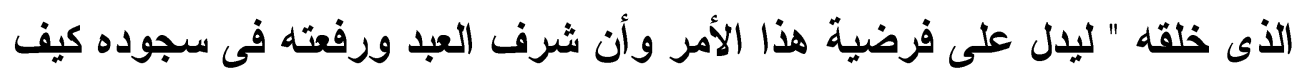

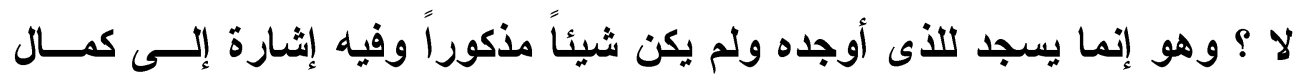

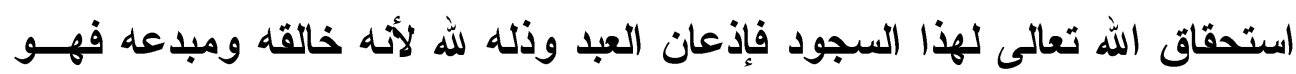

(1) قال سدنة البيان : " يؤتى بالمسند إليه اسم موصول إذا تعين طريقاً لإحضار معناه أما إذا

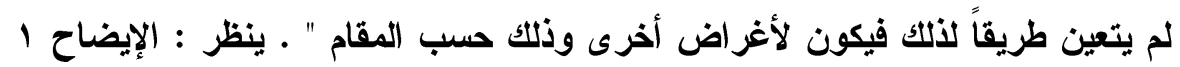

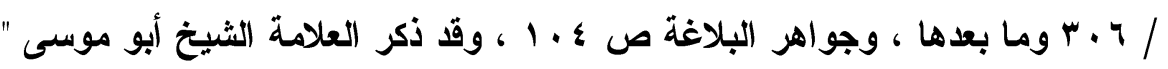

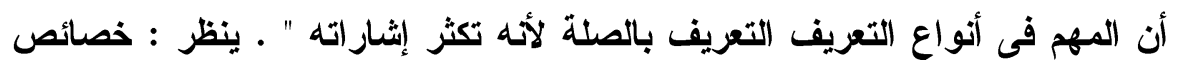

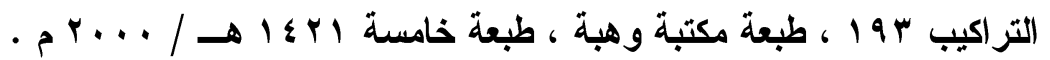


يبرهن بهذا الفعل على أنه مخلوق الله وفى هذا رفعته وشرفه : وقوله

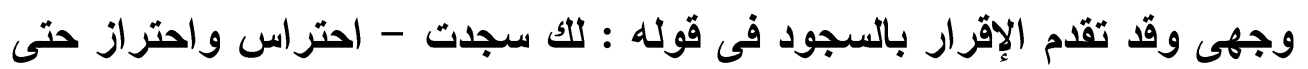

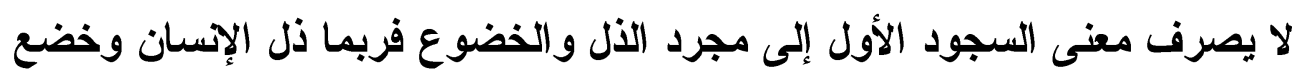

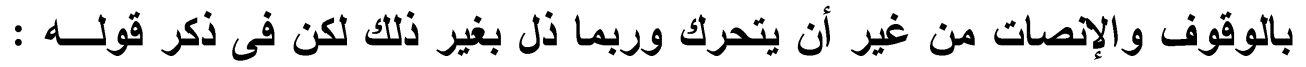

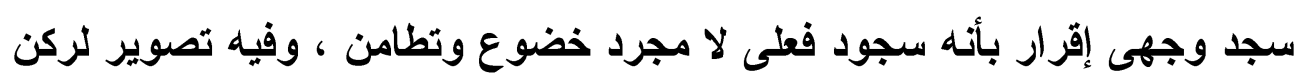

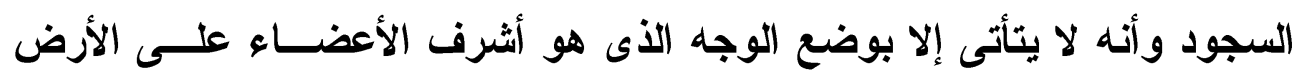

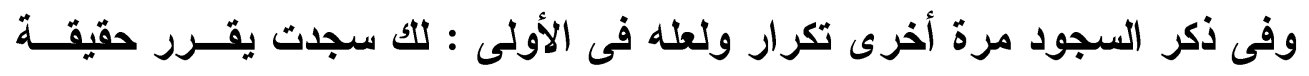

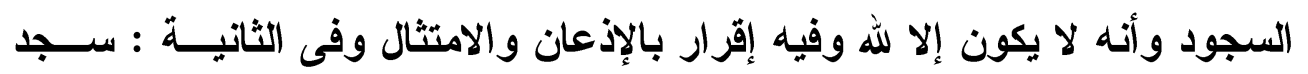

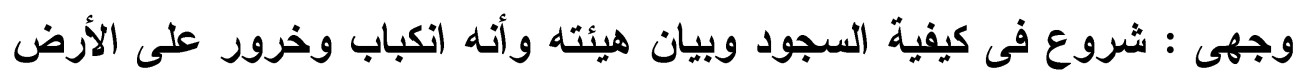

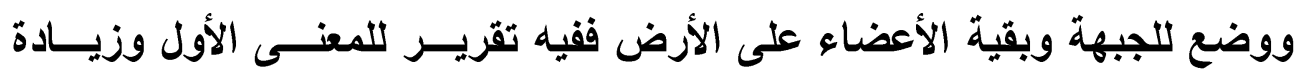

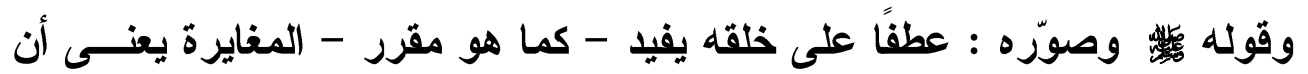

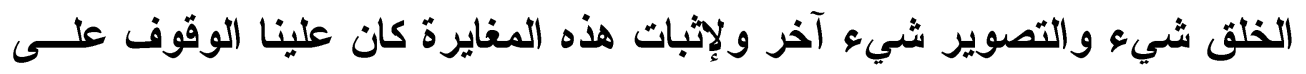

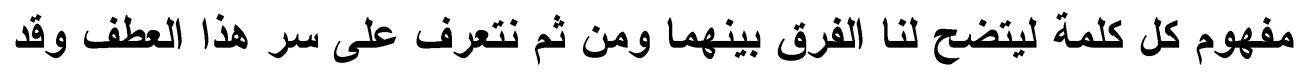

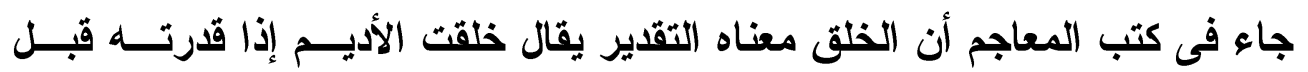

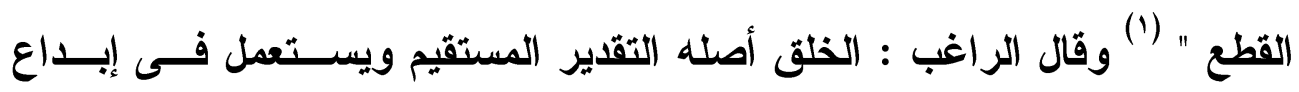

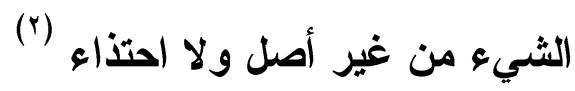

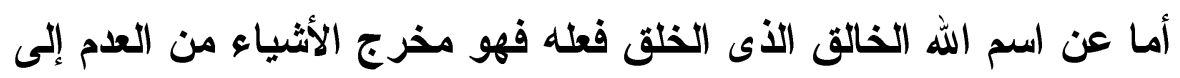

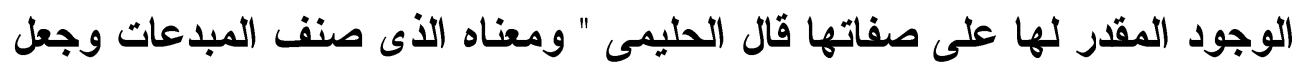

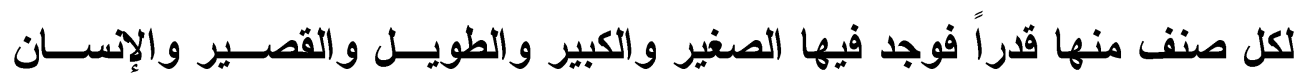

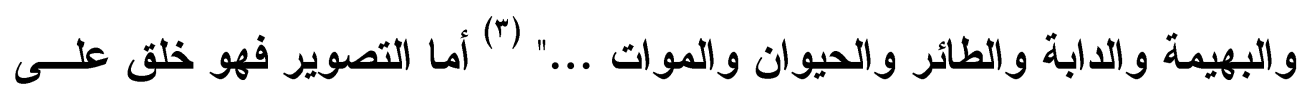
صورة مر ادة تثعر بالعناية قال الراغب " والصورة ما ينتقش به الأعيان ويتميز

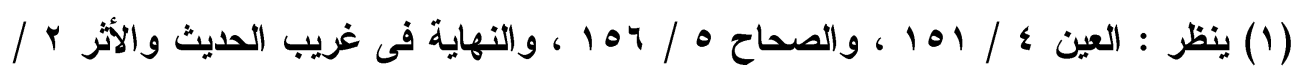

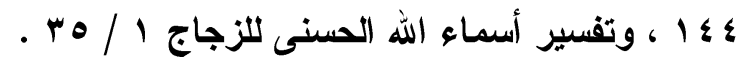

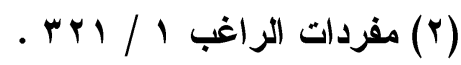

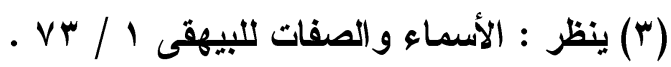


بها عن غيرها " (1) أما عن اسم الله المصور الذى التصوير فعله فقد قال الحليمى

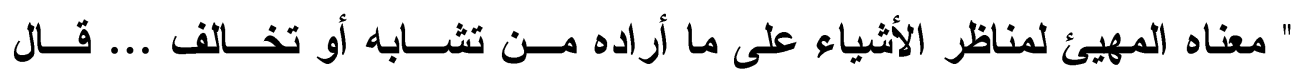

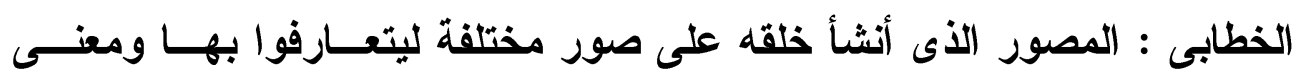

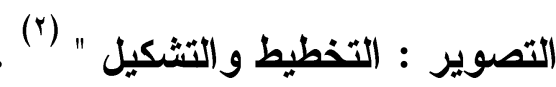
ويفرق الإمام الغزال - رحمه الله - بين أسماء الله تعالى الخالث البــارئ

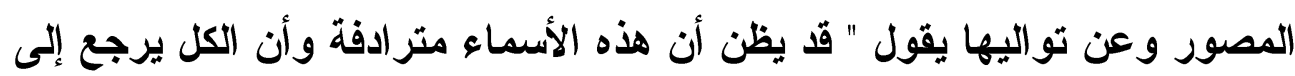

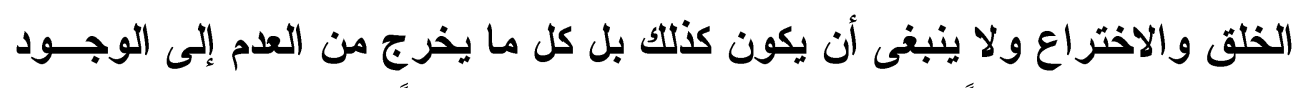

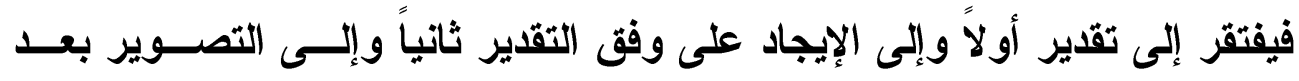

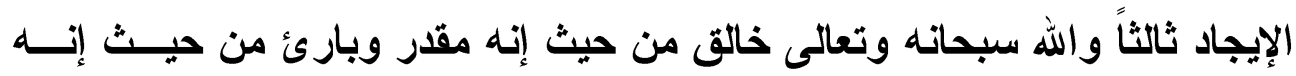

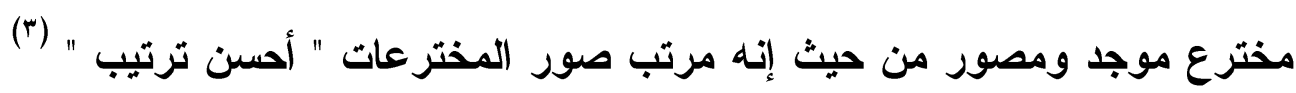

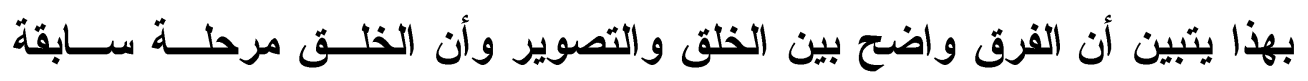

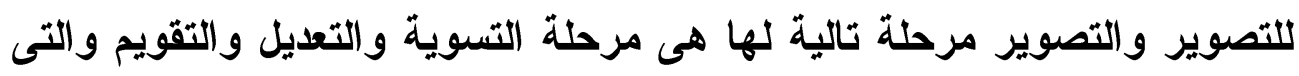

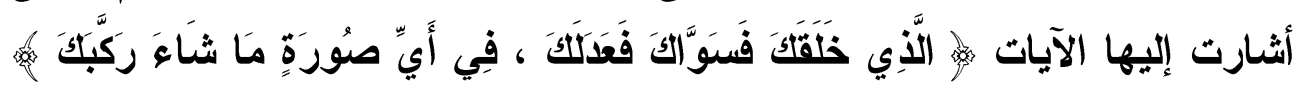

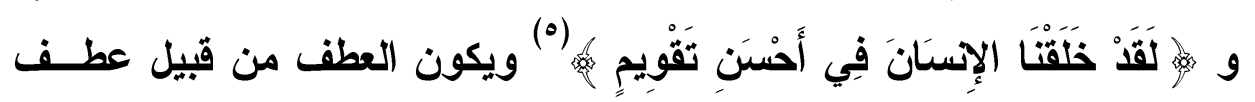

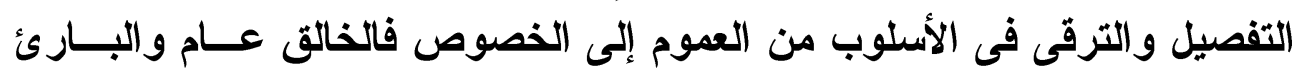

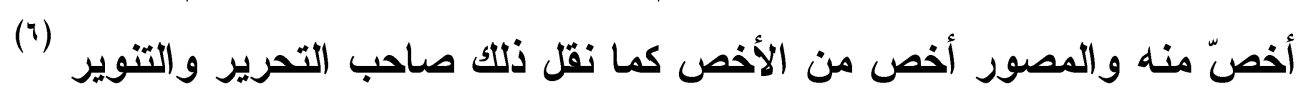
ويكون المعنى " وصوره على هذه الصورة العجيبة أى جعل له فماً وعينين وأنفاً

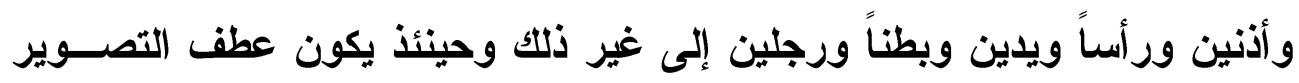

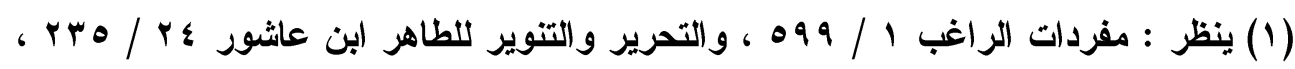

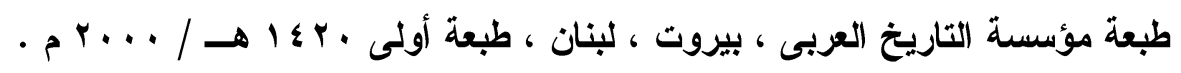

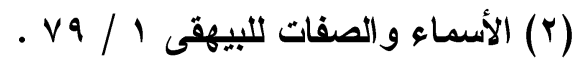

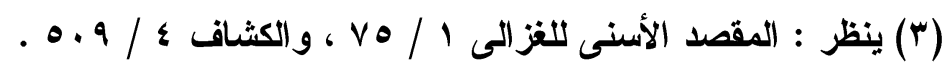

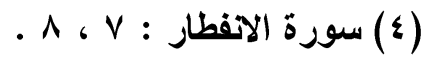

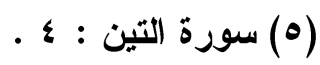

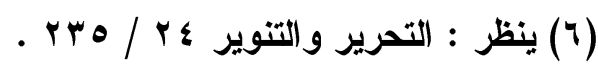


على الخلق مغايرًا وهو - أعنى قوله وصوره - دفع لما قد يقال إنه خلق مــادة

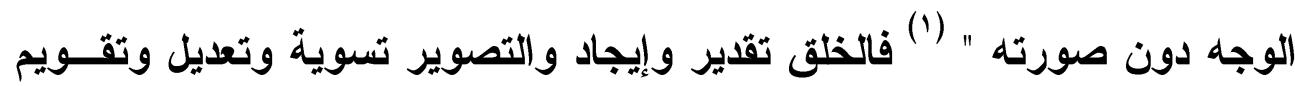

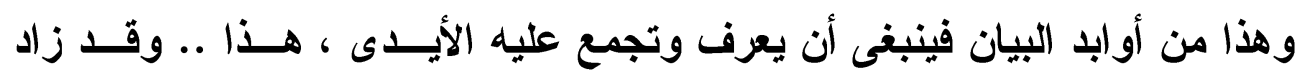

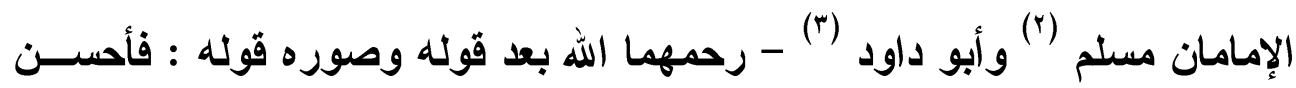

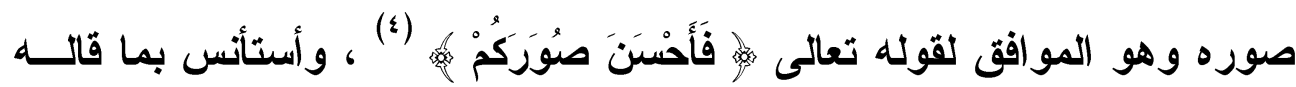

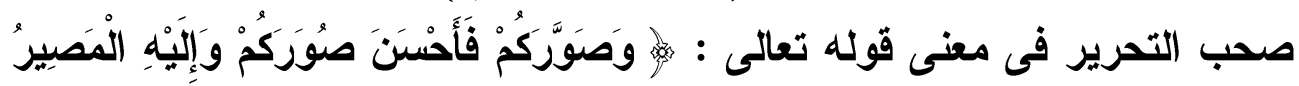

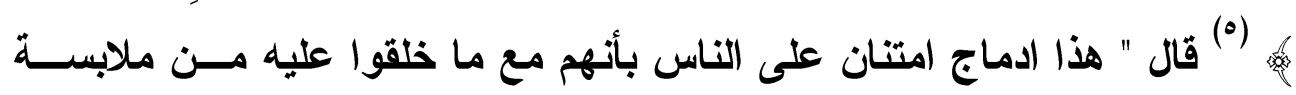

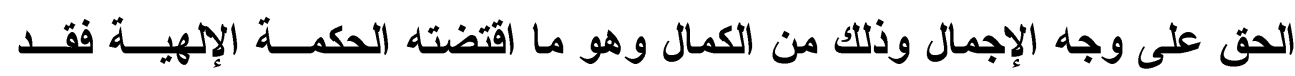

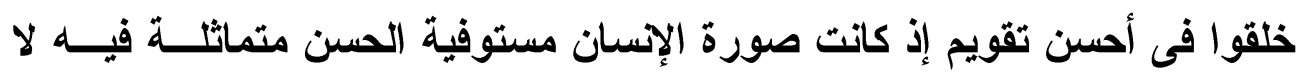

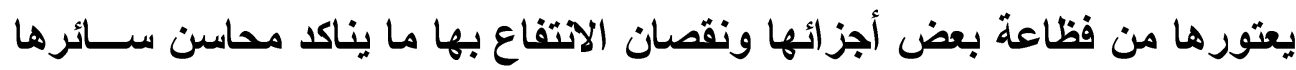

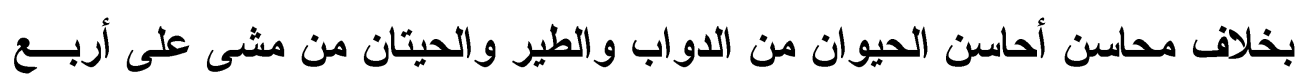

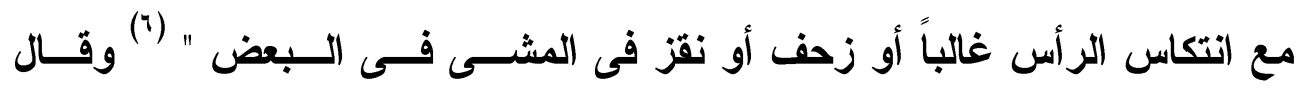

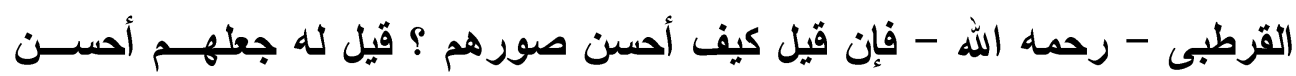

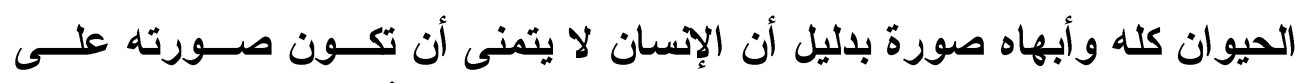

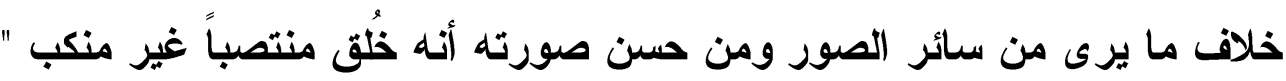

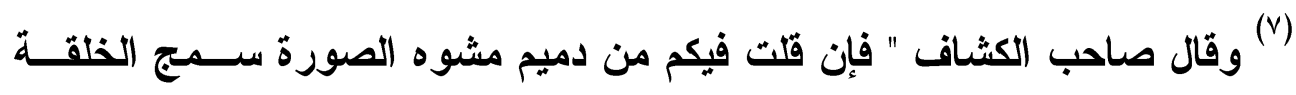

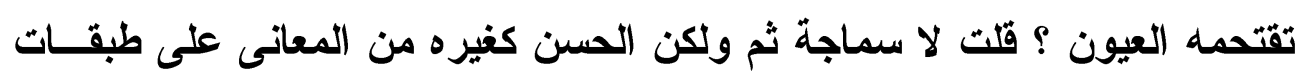

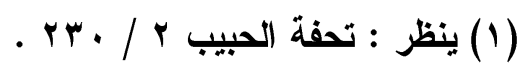

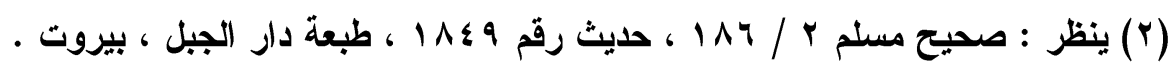

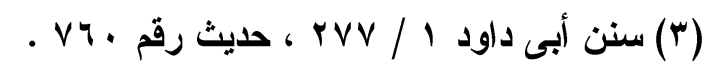

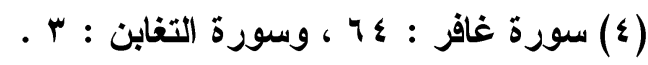

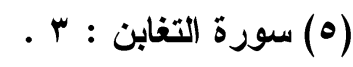

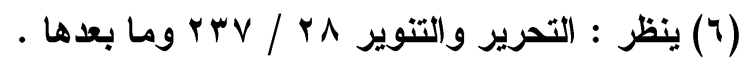

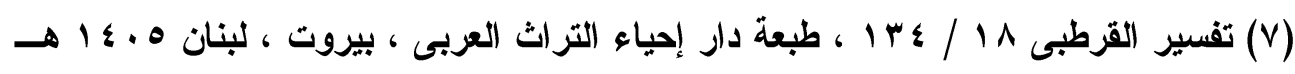

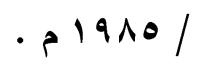


ومراتب فلاحطاط بعض الصور عن مراتب ما فوقها انحطاطاً بينتا وإضافتها إلى

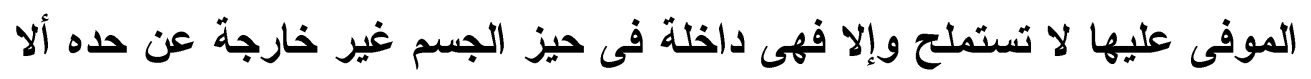

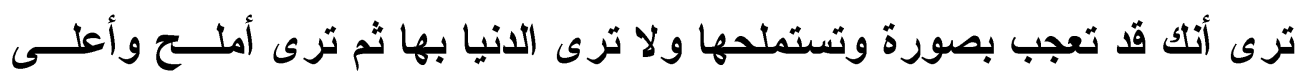

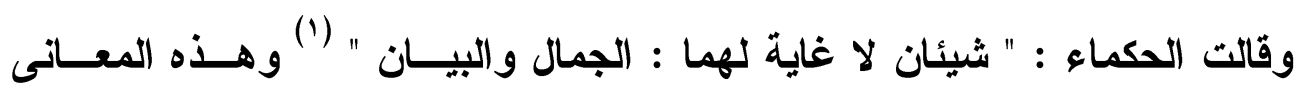

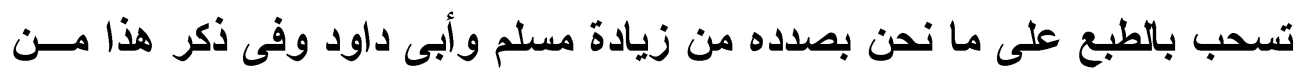
النبى

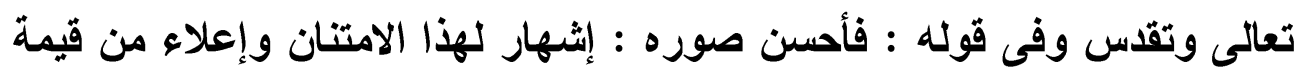

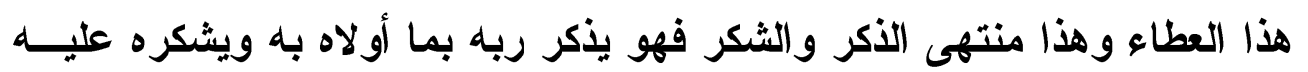

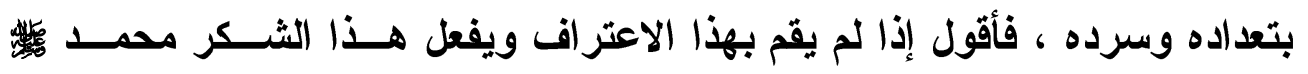

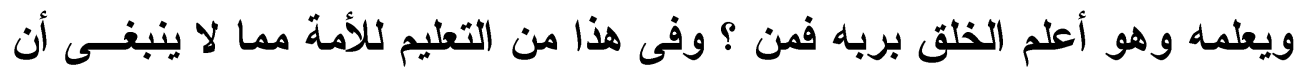

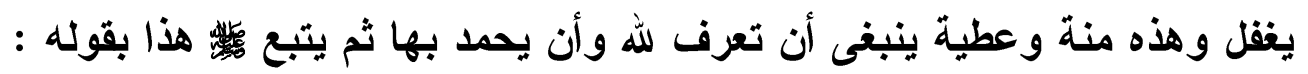

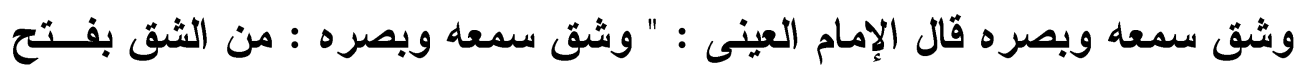

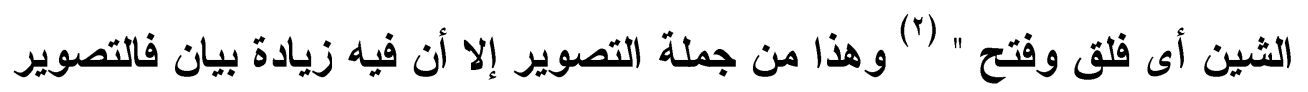

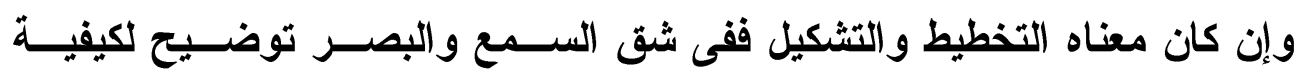

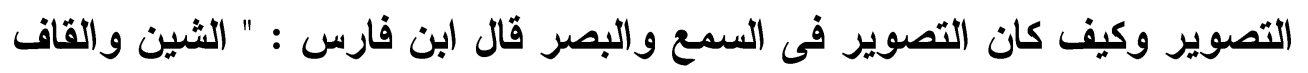

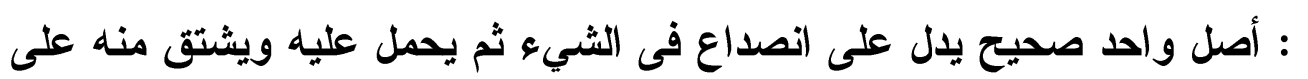

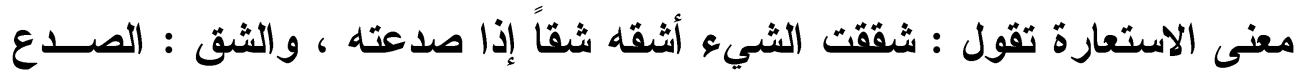

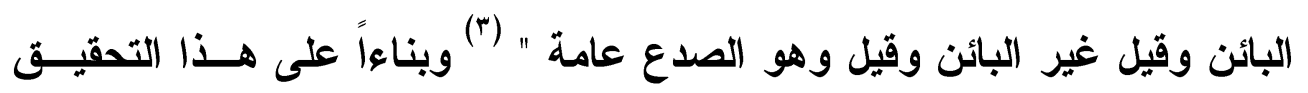

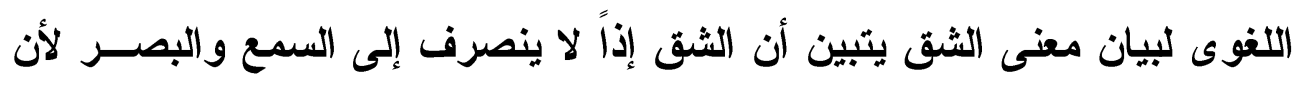

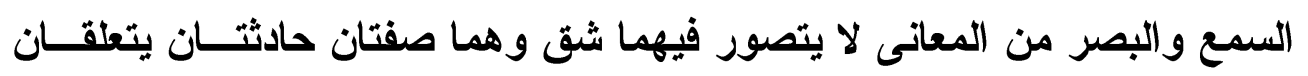

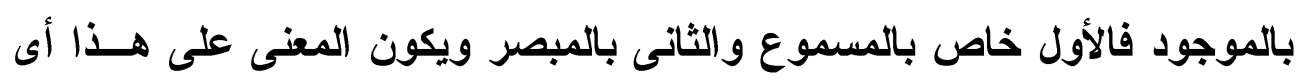

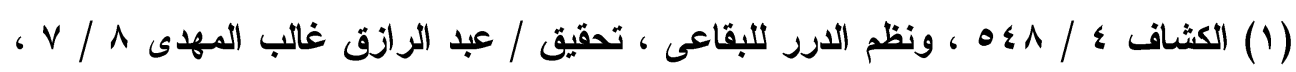

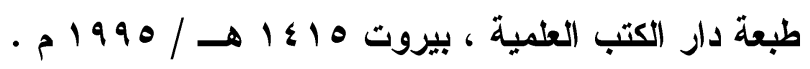

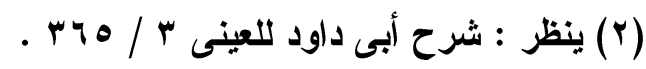

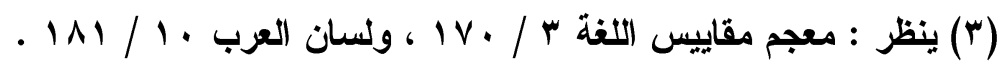


شق طريق السمع والبصر " لأن السمع ليس فى الأننين بل فى مقعر الصماخ " ( )

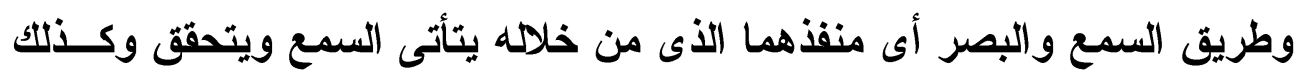

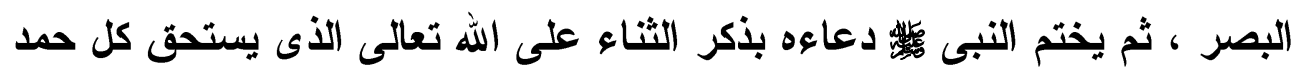

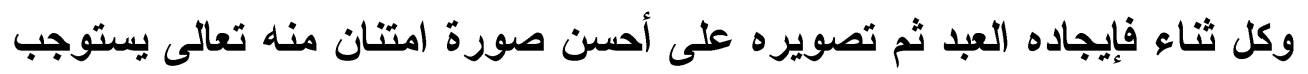

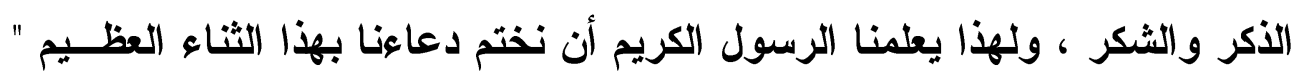

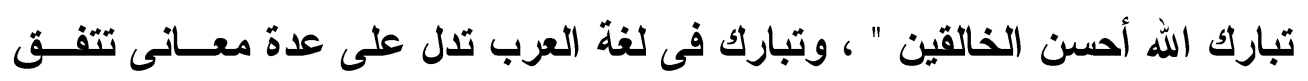

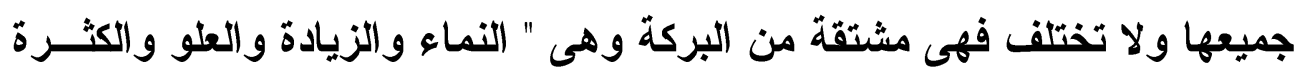

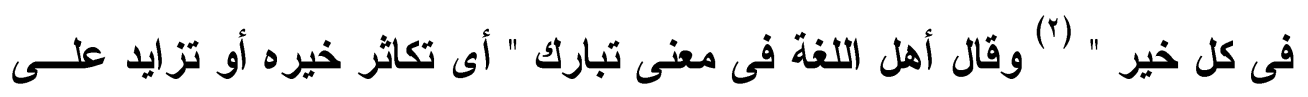

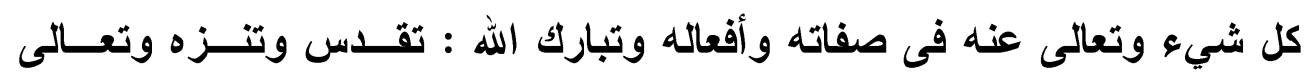
وتعاظم لا تكون هذه الصفة لغيره أى تطهر ، والقدس : الطهر وسئل أبو العباس عن تفسير تبارك الله فقال ارتفع ، والمتبارك : المرتفع ، وقال الزجاج : تبارك : تفاعل من البركة كذلاك يقول أهل اللغة ، وروى عن ابن عباس ومعنى البركــة : الكثرة فى كل خير وقال فى موضع آخر تبارك : تعالى وتعاظم وقال ابن الأببارى

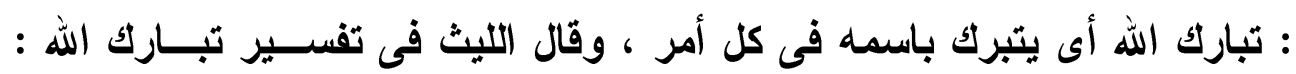

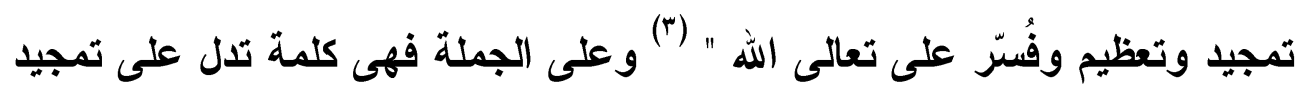

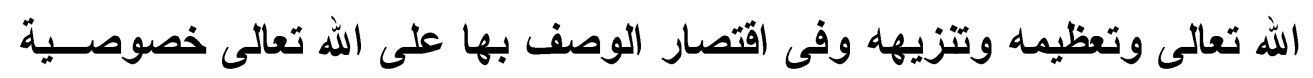

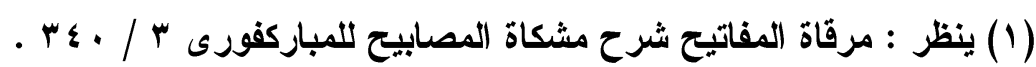

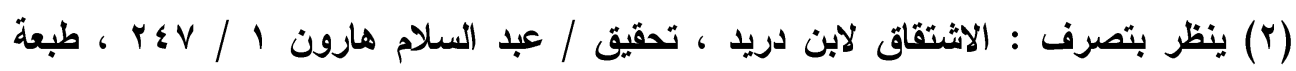

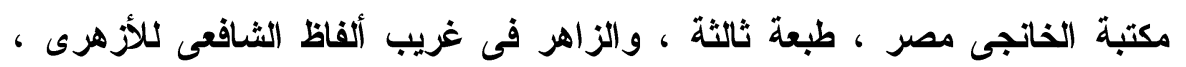

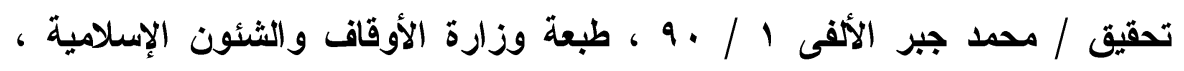

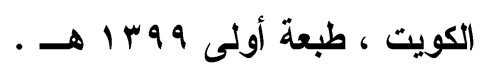

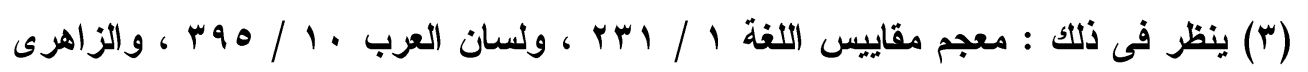

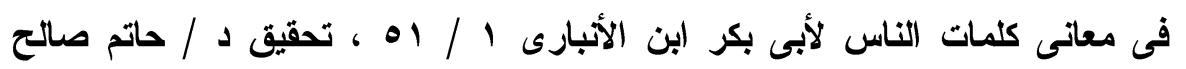

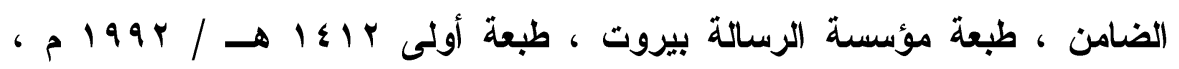

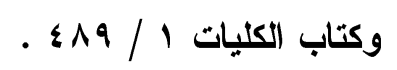


فى معناها ومبناها فهى كلمة لا تطلق ولا يوصف بها غير الله تعالى وقالوا إنهـا

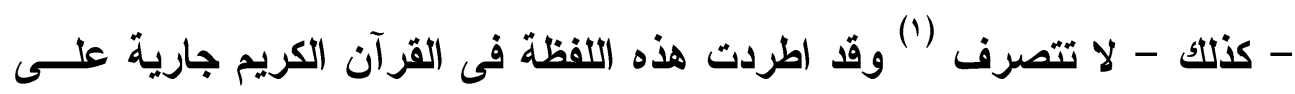

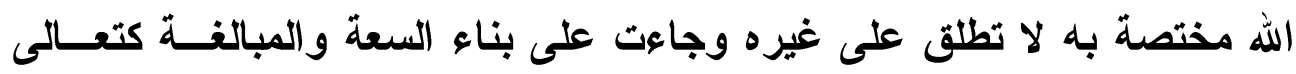

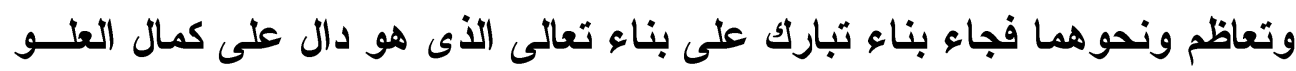

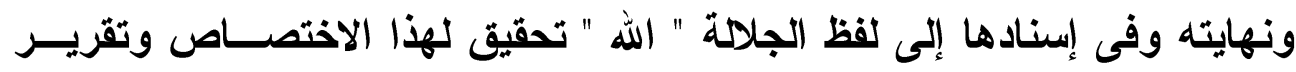

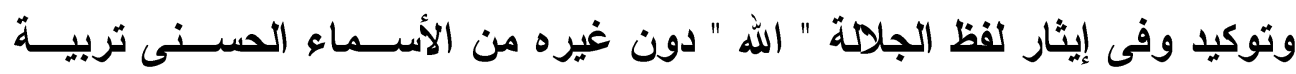

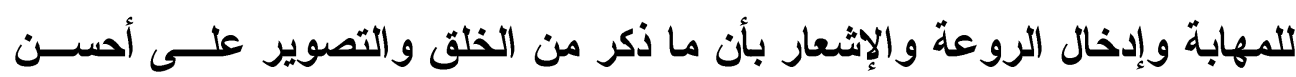

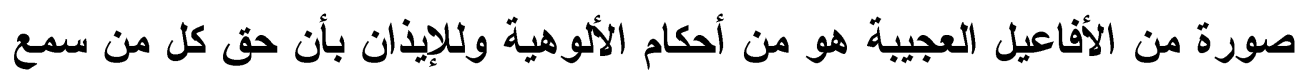

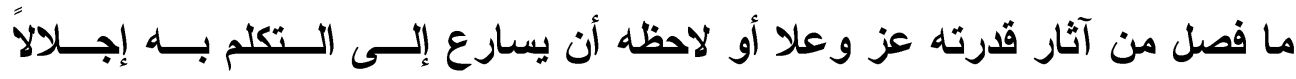

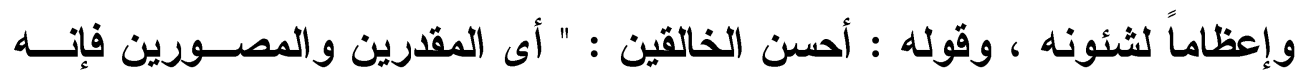

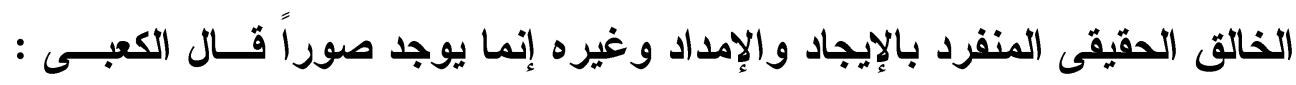

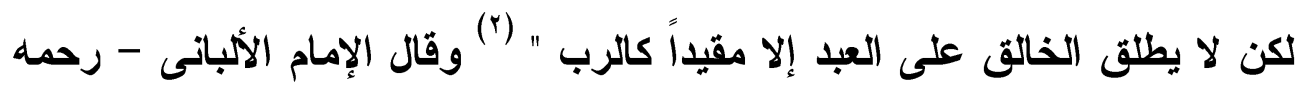

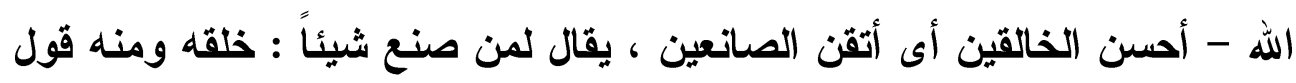

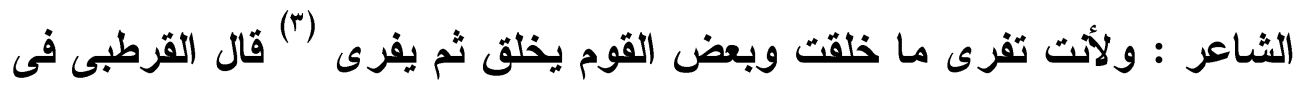

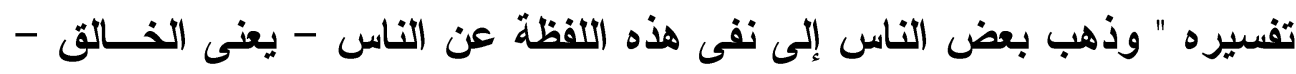

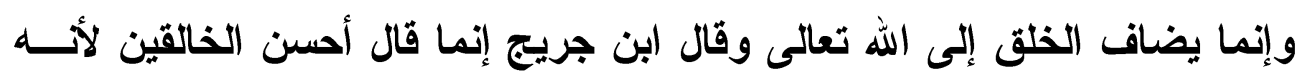

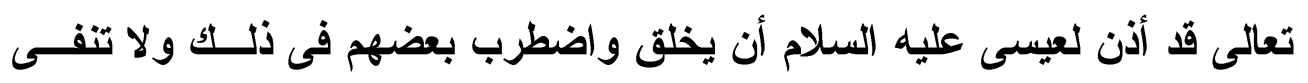

(1) قال ابن عطية " وتبارك لا يتصرف فى كلام العرب لا يقال منه يتبارك وهذا منصوص عليه

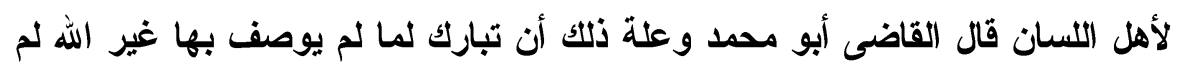

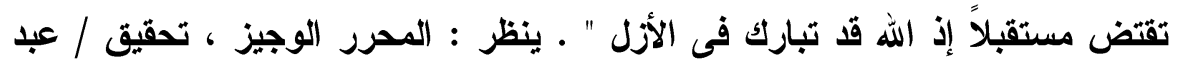

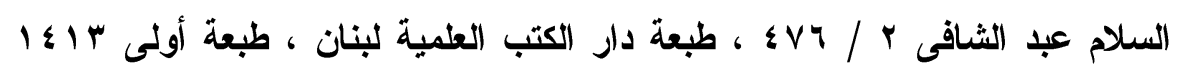

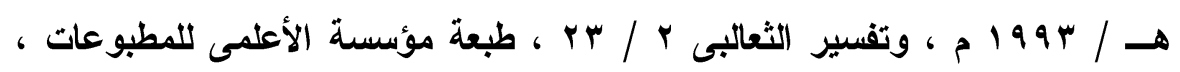

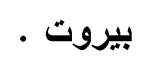

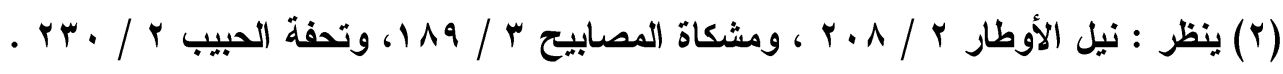

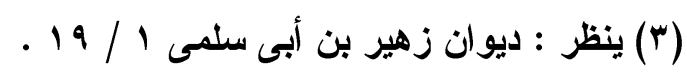


اللفظة عن البشر فى معنى الصنع وإنما هى منفية بمعنى الاختراع والإيجاد مـن

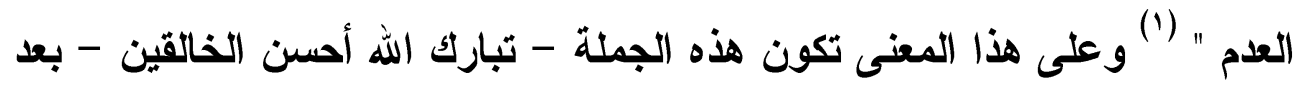

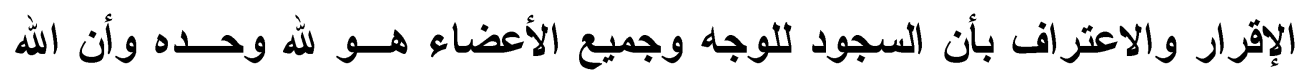

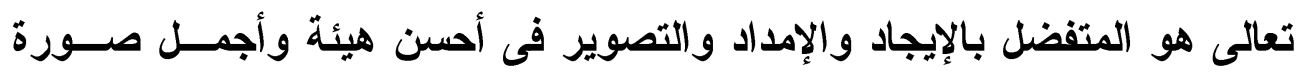

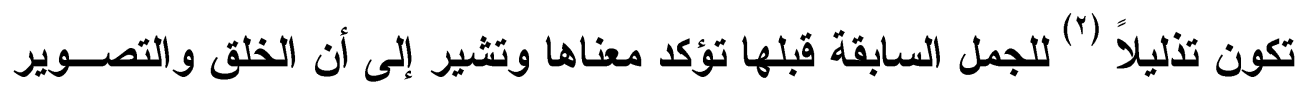

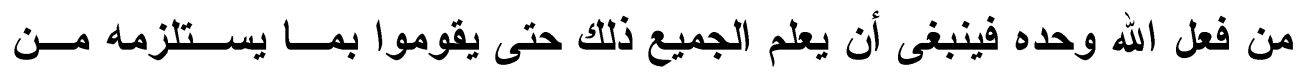

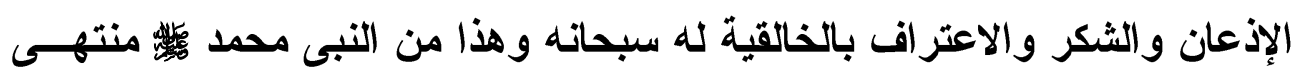

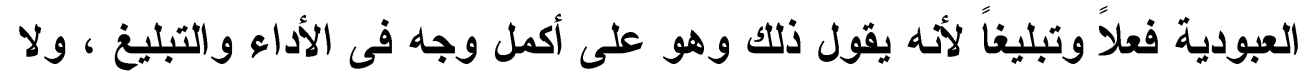

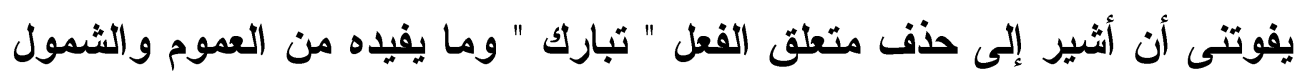

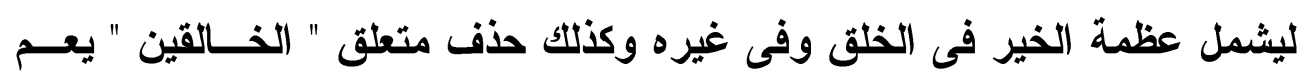
خلق الإنسان وخلق غيره كالجبال و السموات ، والله تعالى أعلم .

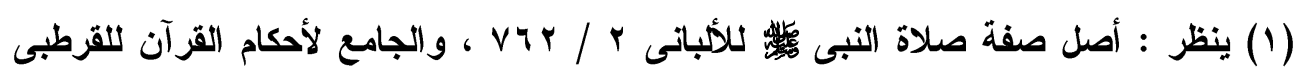

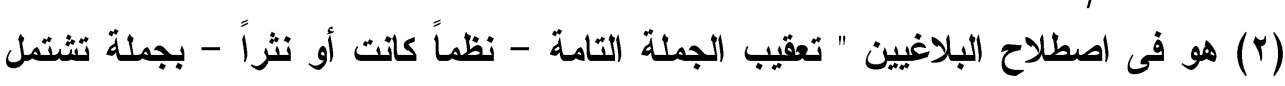

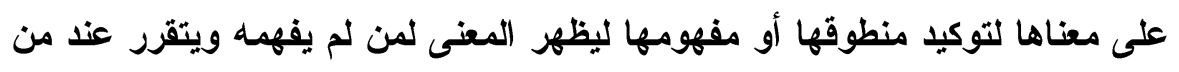

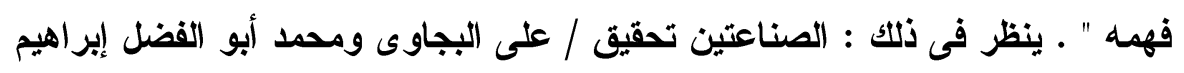

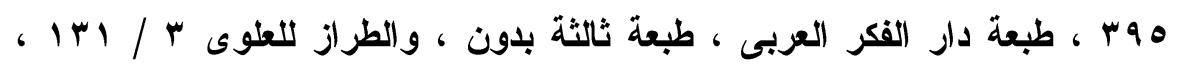

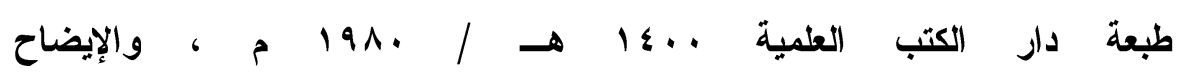

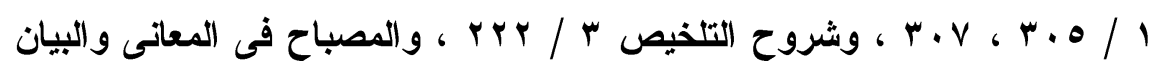

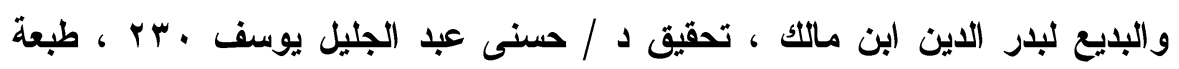

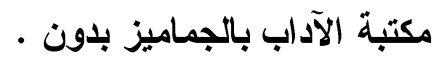




\section{البمثث الخامس \\ ما يقال من الدعاء بين السجدتين}

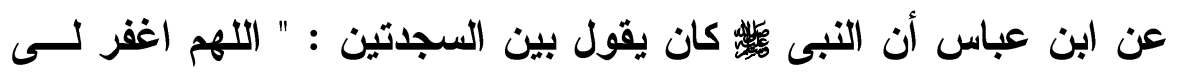
وارحمنى وعافنى واهدنى وارزقنى " من أركان الصلاة ركن لابد منه فى الصلاة وهو الجلسة بين الســـلتين

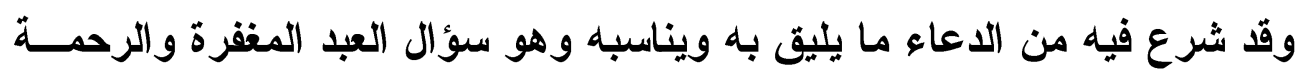

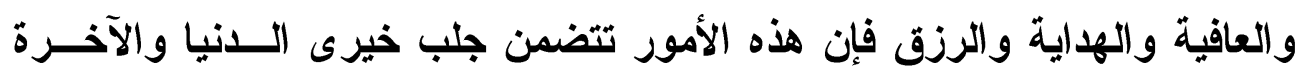

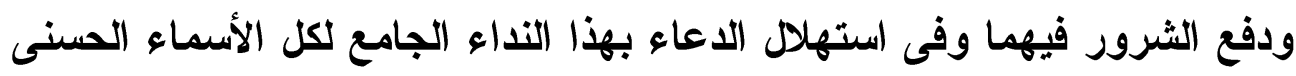
والصفات العلى والذى فيه من التفخيم والتعظيم ما يقوم مقام التعــريض بعظمــة

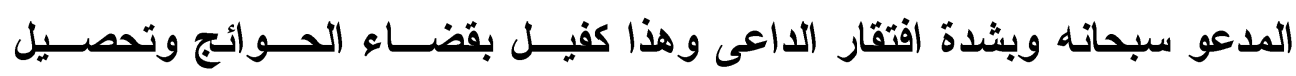

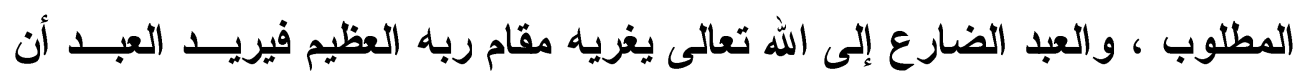

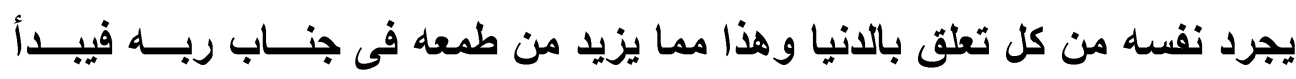

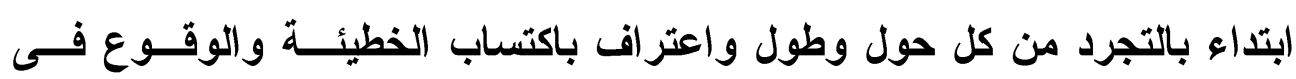
المعصية حتى يقدم على الله نقياً صافيا وهذا هو سر البلدء بطلب المغفرة أولاً ولك ونك

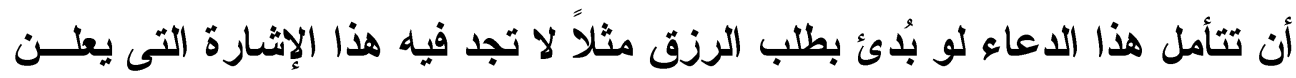

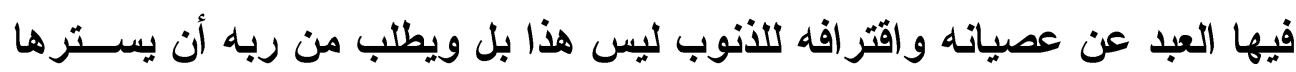
عليه وهذا إيذان بصدق الاعاء وإعلان بالافتقار إلى مغفرة الله والوقاية من آثار

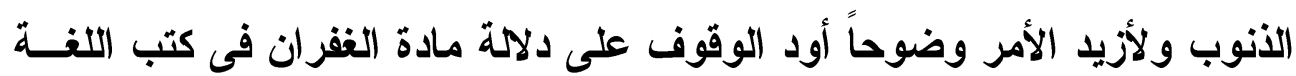

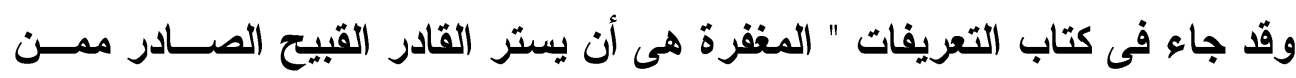

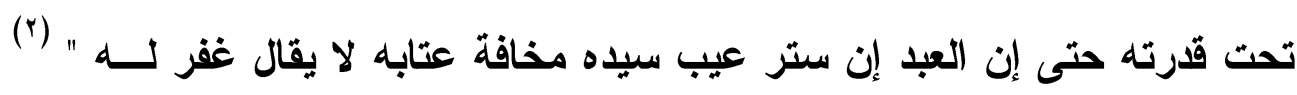
وفى هذا الكلام دلامة على أن الغافر لابد أن يكون قادراً والمغفور له له لابد أن يكون

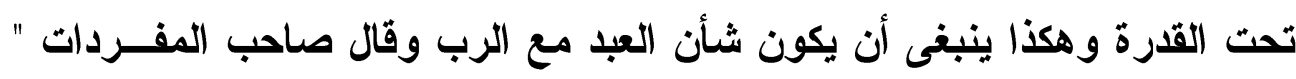

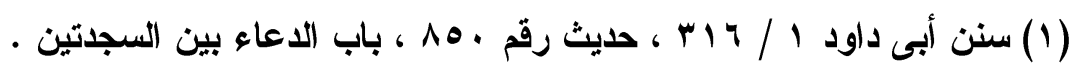

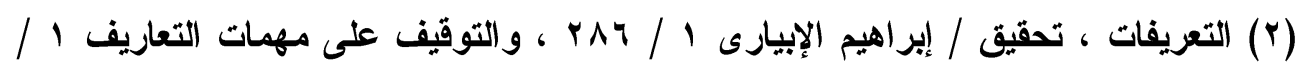


الغفر هو إلباس ما يصونه عن الانس ومنه قيل اغفر ثوبك فى الوعاء ، واصبغ

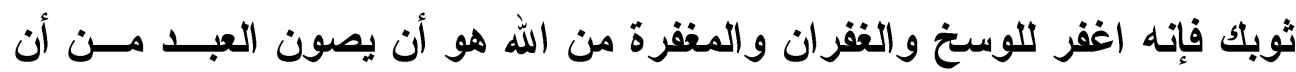

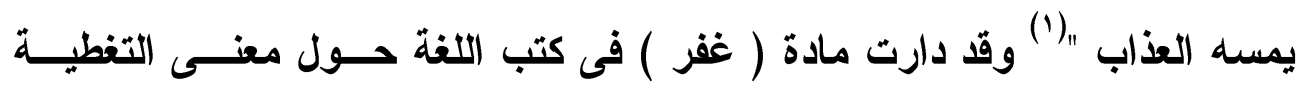

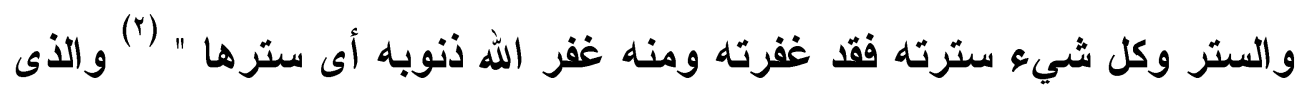

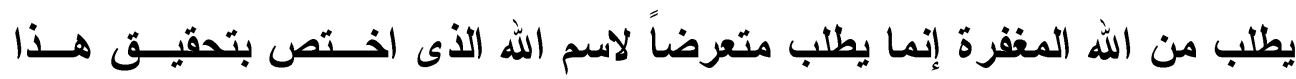

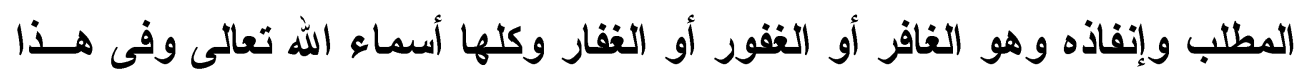

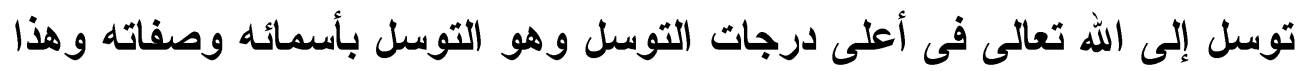
من دعاء المسألة قال البيهقى " قال الحليمى فى معنى اسم الله الغفور " هو الذى الذى

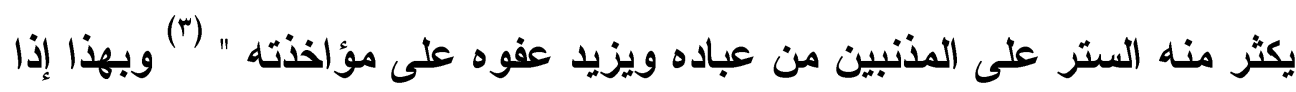

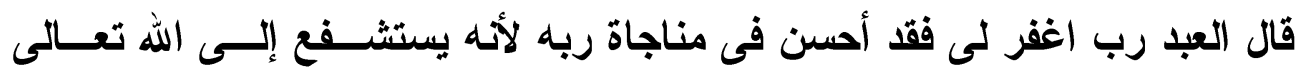

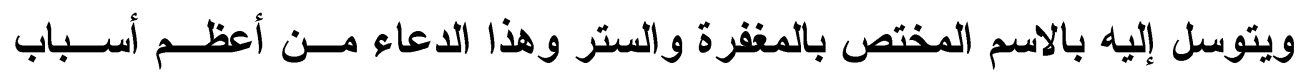

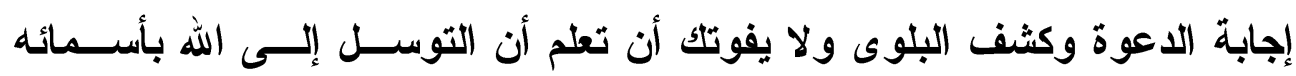

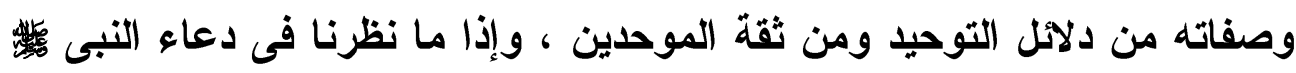

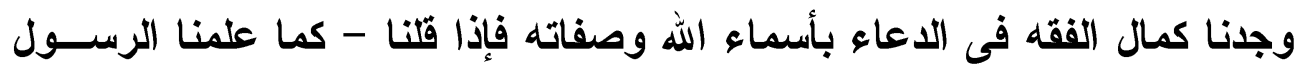

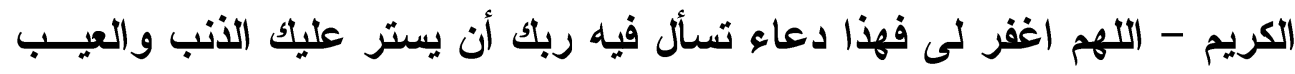

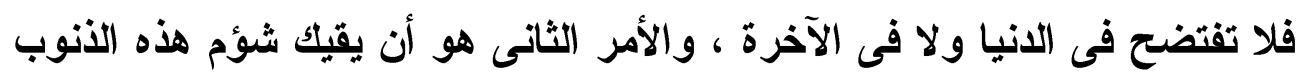

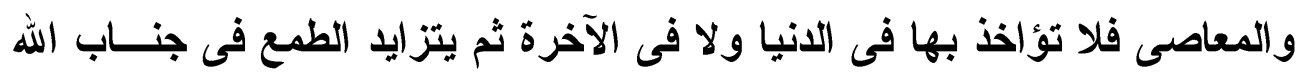

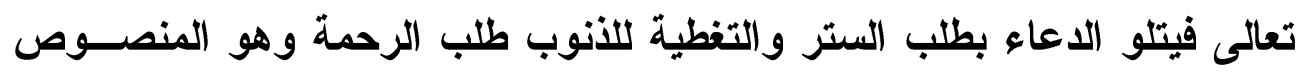

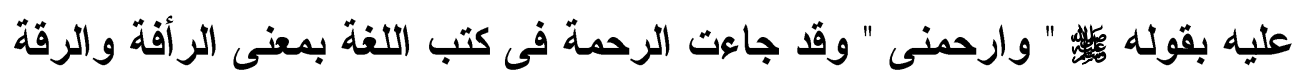

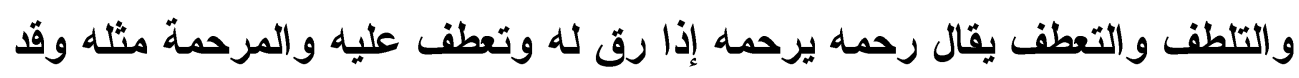

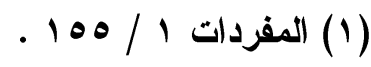

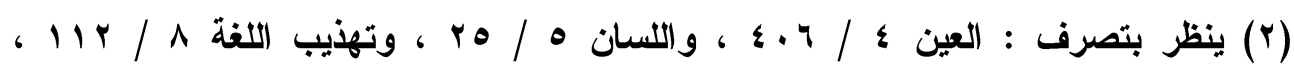

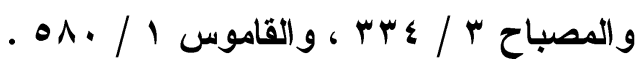

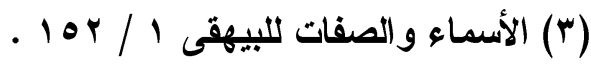


رحمته وترحمث عليه وتر احم القوم رحم بعضــهم بعضــاً " (1) قـــال الر اغـب :

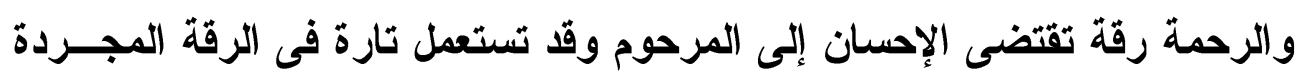

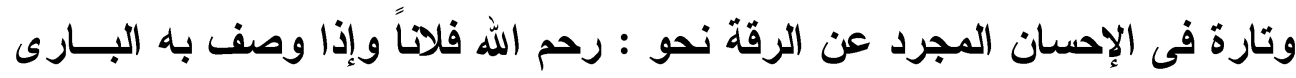
فليس ير اد به إلا الإحسان المجرد دون الرقة " (r) وهذا من الراغب يعد في ألعانى درجات الاقة والاحتراز من الإطلاق العام لمفهوم الرحمة حيث لا يصح أن تطلق

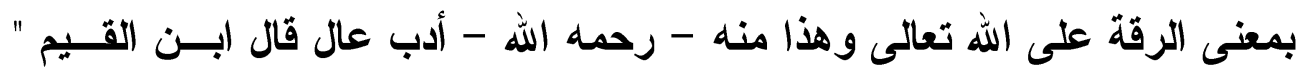

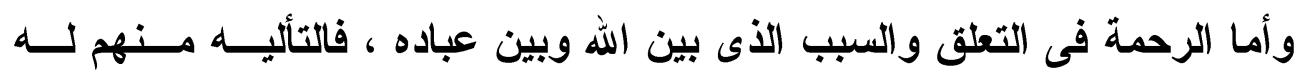
والربوبية منه لهم ، والرحمة سبب واصل بينه وبين عباده بها أرسل إليهم رسله وأنزل عليهم كتبه وبها هداهم وبها أسكنهم دار ثوابه وبها رزقهم وعافاهم وأنعم

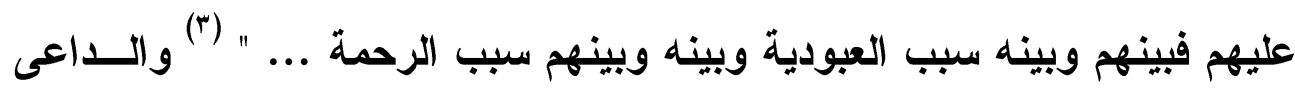
بطلب الرحمة إنما يتعرض لاسم الله الرحيم أو الرحمن وهو الأى من شــأنه أن

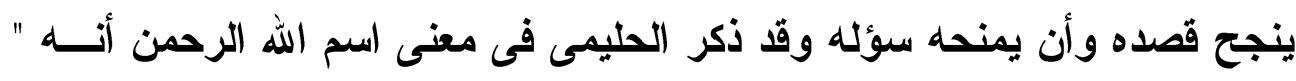

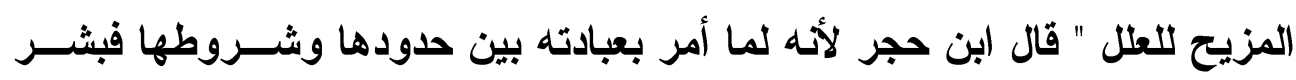
وأنذر وكلف ما تحمله بنيتهم فصارت العلل عنهم مزاحة والحجج منهم منقطعة " (؛) أمـا عن اسم الله الرحيم سبحانـه فقد ذكر الحليمى " أنه المثيب على العمل فــلا

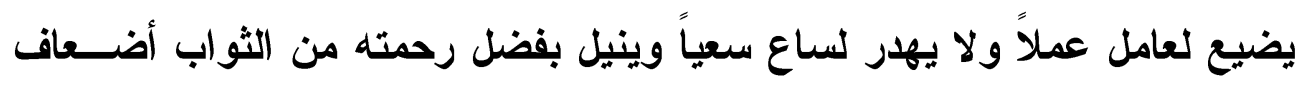

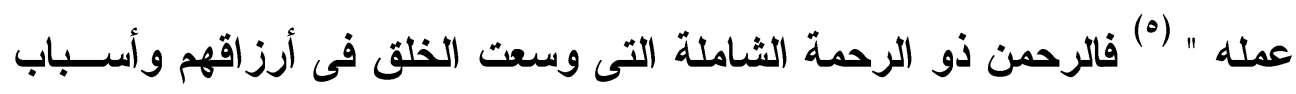

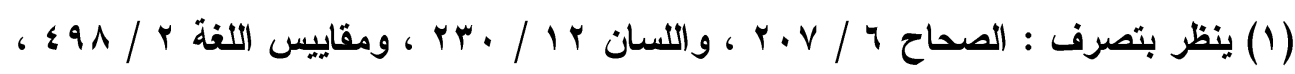

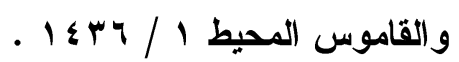

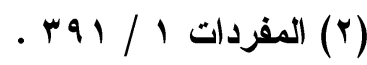

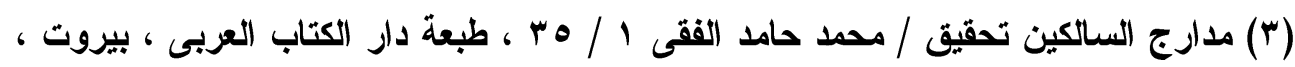

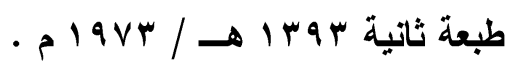

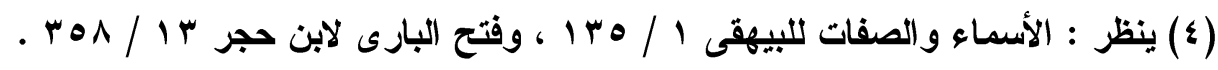

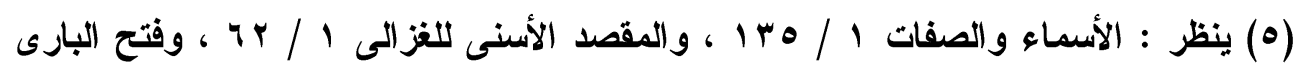


معايشهم ومصالحهم وعمت المؤمن و الكافر والصالح و الطــالح ، وأمســا الـرحيم

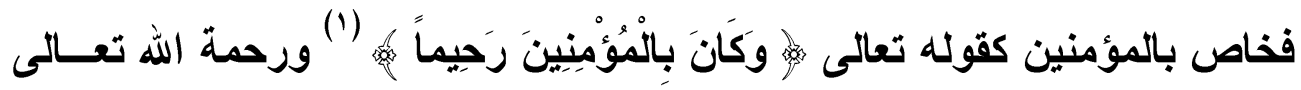

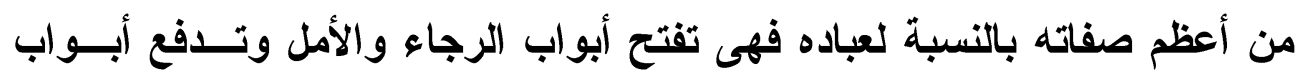

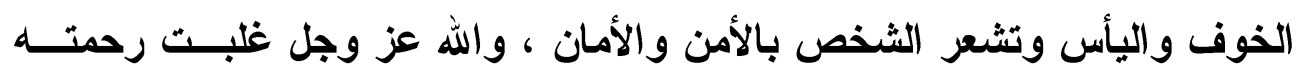

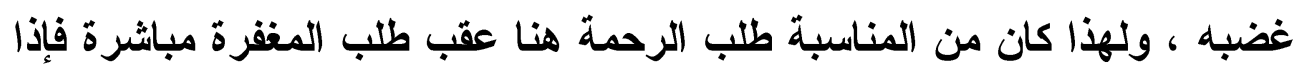

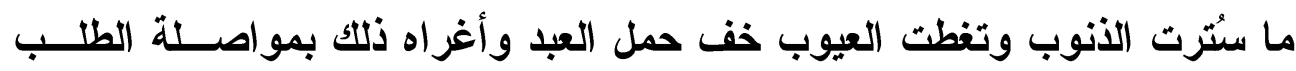

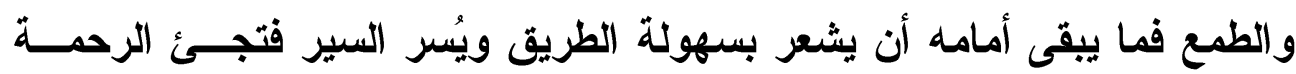

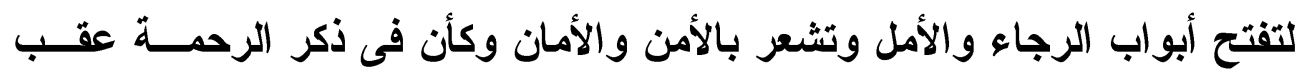

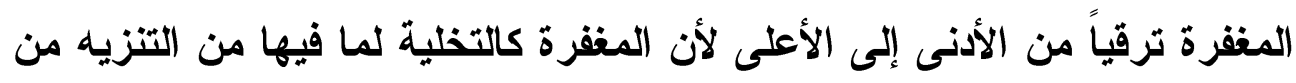

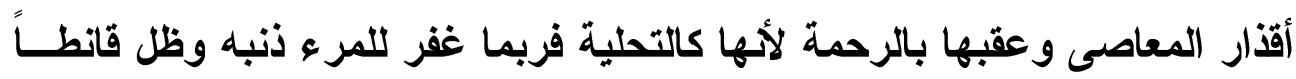

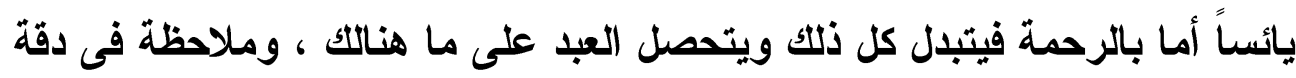

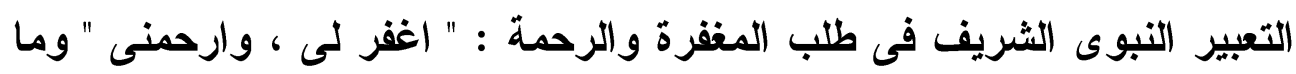

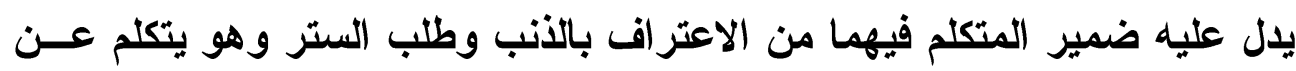

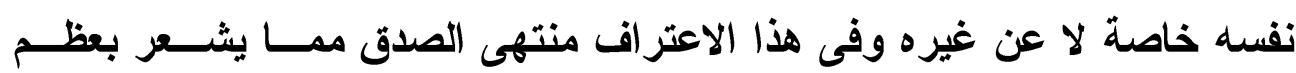

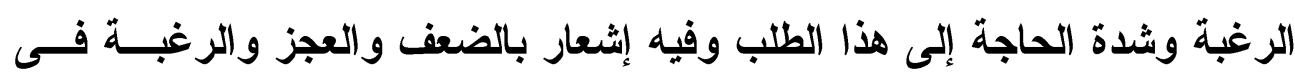

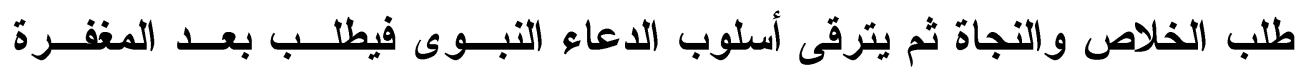

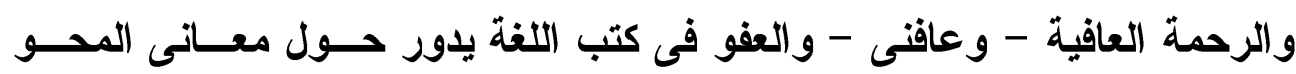

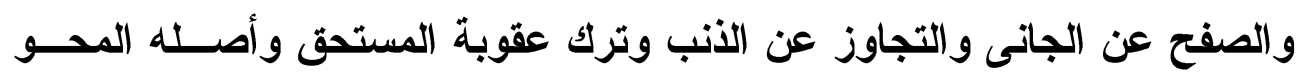

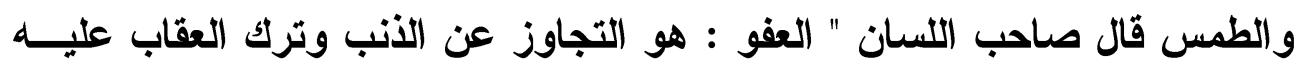

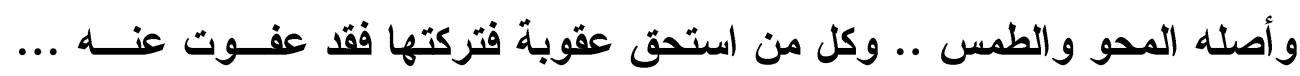

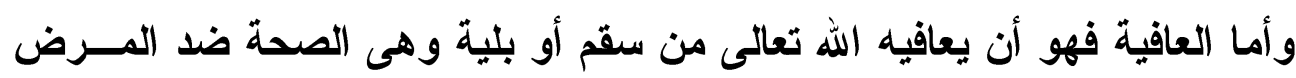

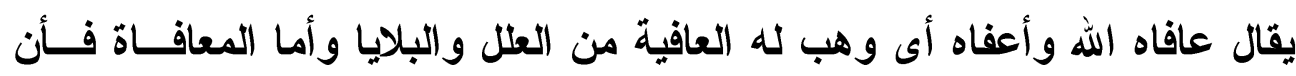

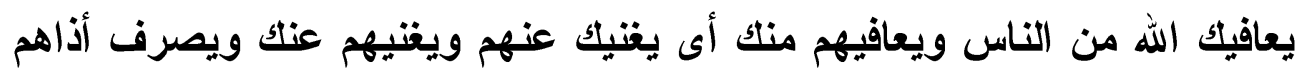

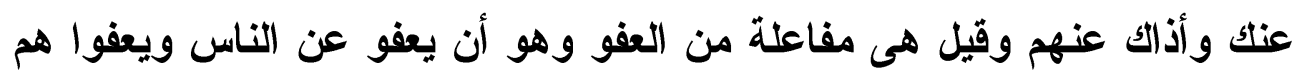


عنهـ " (1) وقال الر اغب : " العفوّ : القصد لتناول الثيع يقال عفــاه واعتفــاه أى

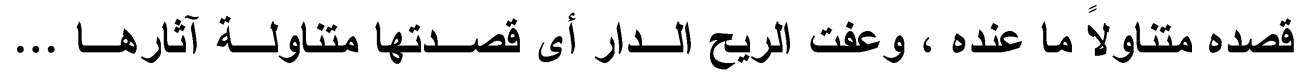

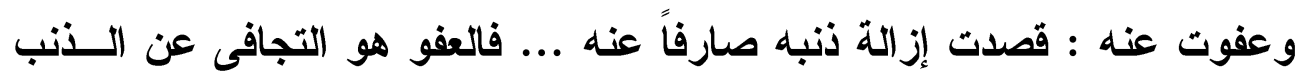

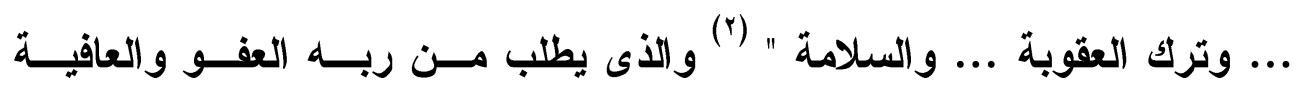

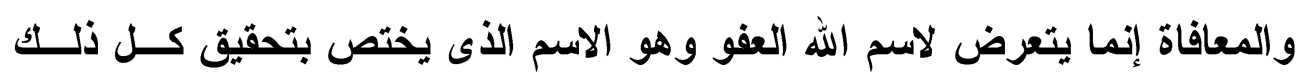

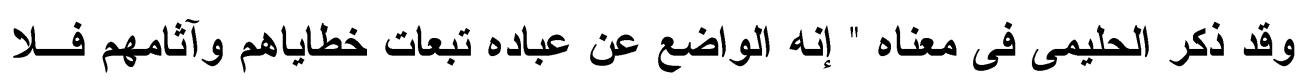

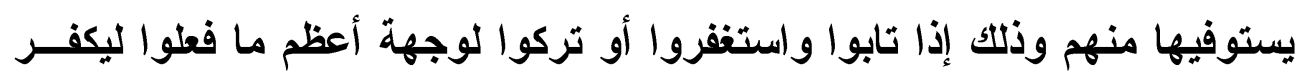

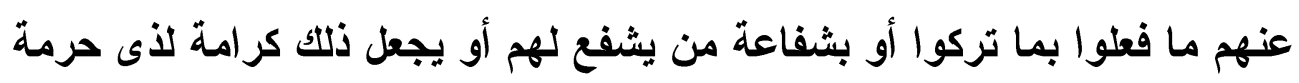

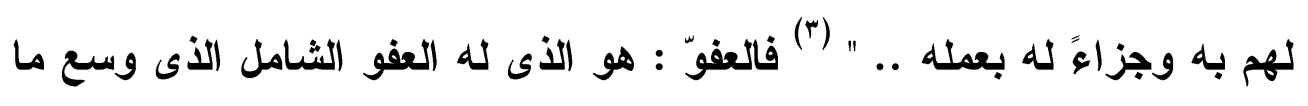
يصدر من عباده من الأنوب ولاسيما إذا أتوا بما يسبب العفو عنهم من الاستغفار

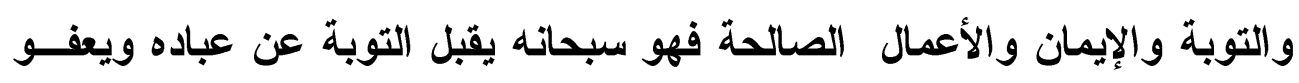

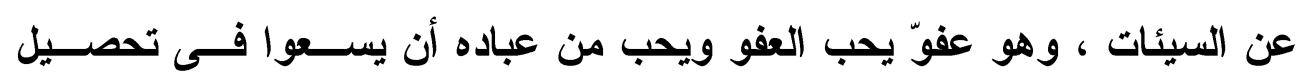
الأسباب التى يناولون بها عفوه من السعى فى مرضاته والإحسان إلى خلقه ولهذا

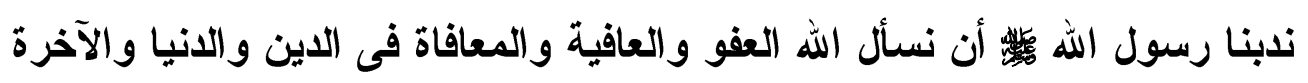
فقد سألت أم المؤمنين عائشة - رضى الله تعالى عنها - كما جاء فى ليلة القدر

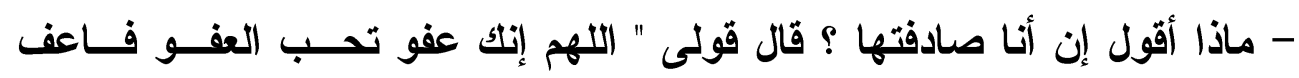

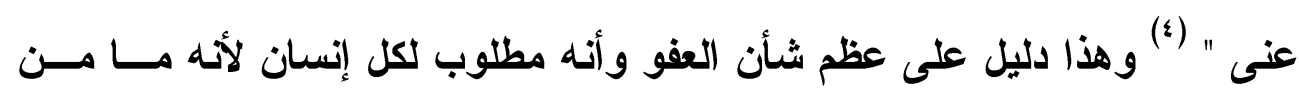
عبد إلا وقد ألمّ بذنب فإذا صفا قلبه رجا عفو ربه بمحو ذنبه وليقدر على تحقيق

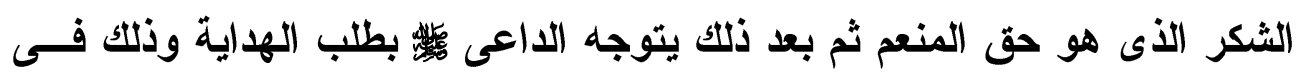

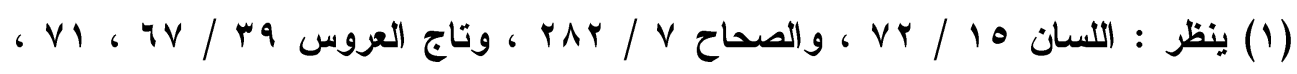

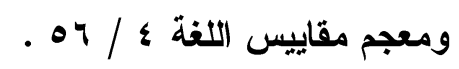

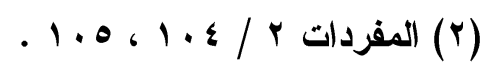

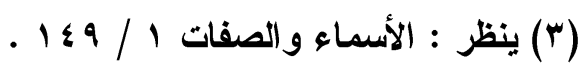

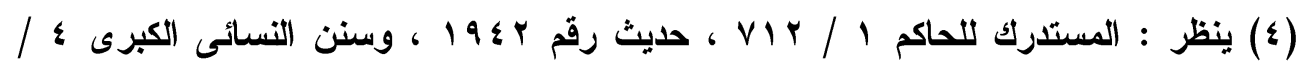

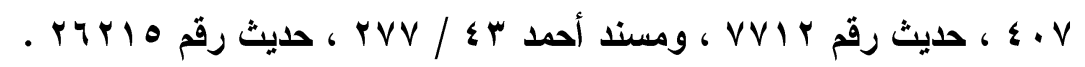


قوله : " واهدنى " و الهداية كما هى فى كتب اللغة " الهـــى : الرشــاد والالاهـة

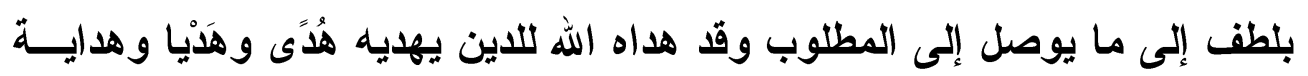

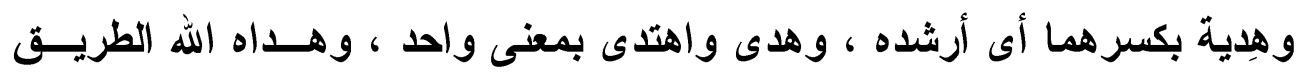

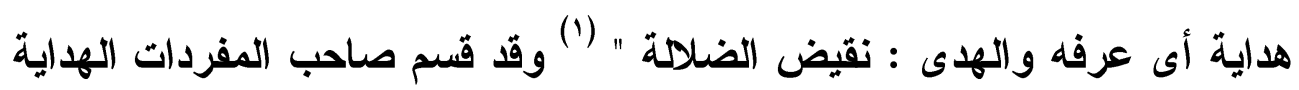

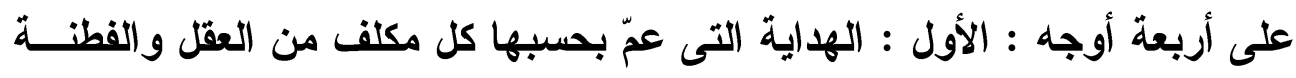

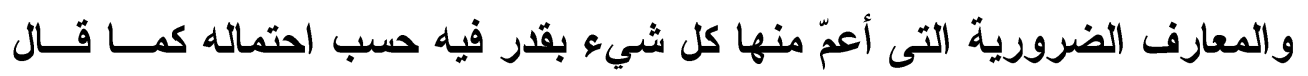

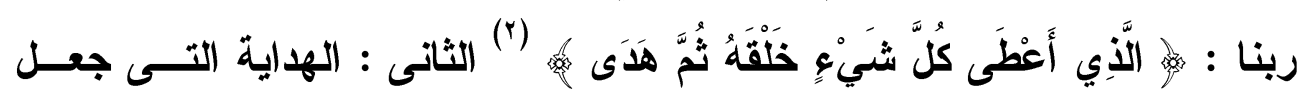

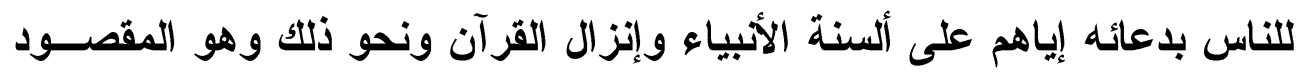

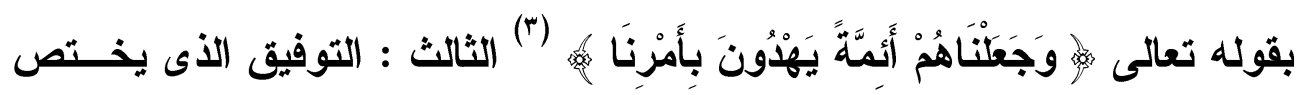

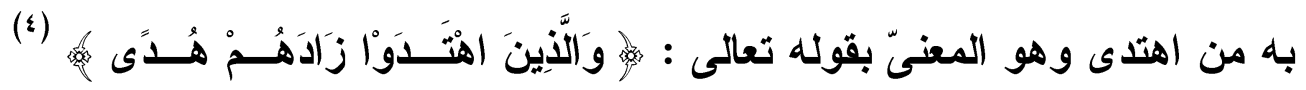

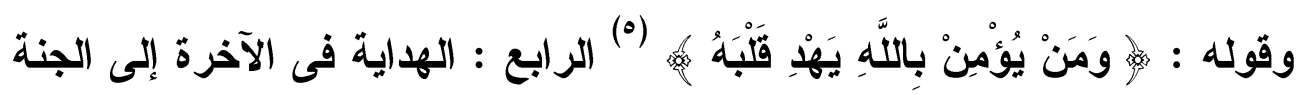

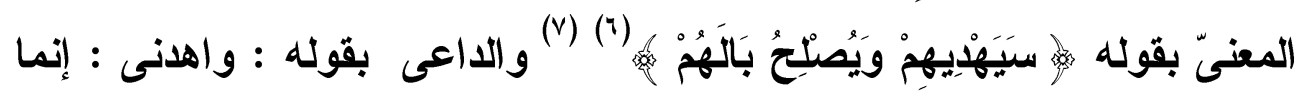
يتعرض لاسم الله الهادى وقد قال الحليمى فى معناه " هو الادئل على على سبيل النجاة

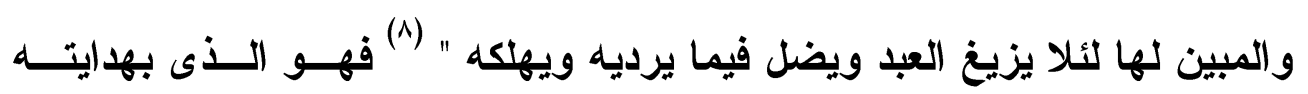

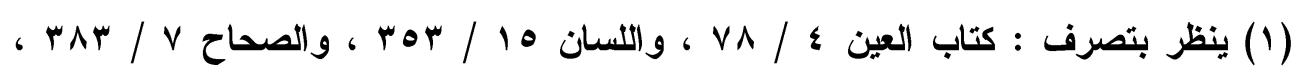

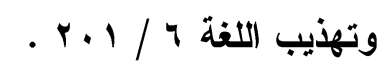

$$
\begin{aligned}
& \text { (T) سورة طه : .O (T) }
\end{aligned}
$$

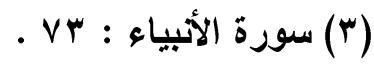

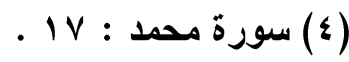

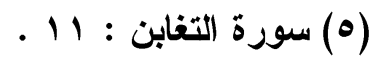

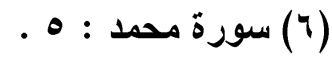

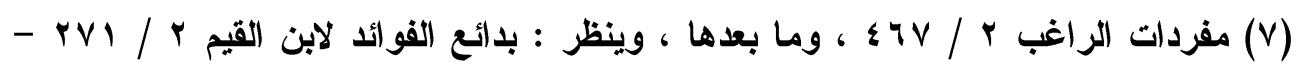
. rVr

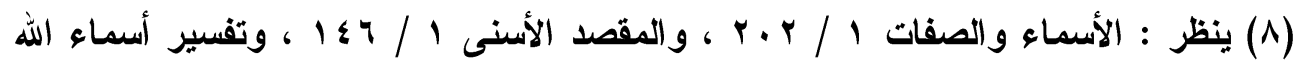

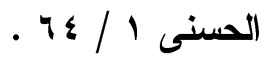


اهتدى أهل ولايته وبهدايته اهتدى الحيوان لما يصلحه واتقى ما يضــره ، وهــو التها الأى هدى كل مخلوق إلى ما لابل منه فى قضاء حاجاته ، والههاية أكبــر نعمــة

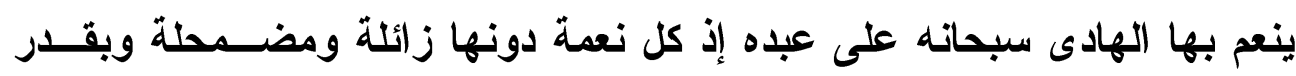
هدايته تكون سعادته فى الانيا وطيب عيشه وراحة باله وكذا فوزه ودرجته فـى

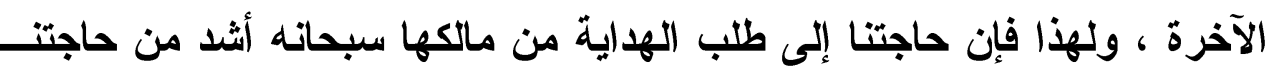

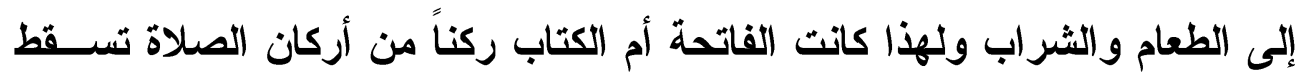

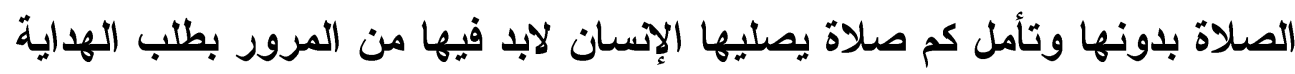

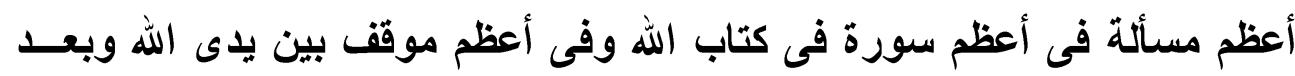

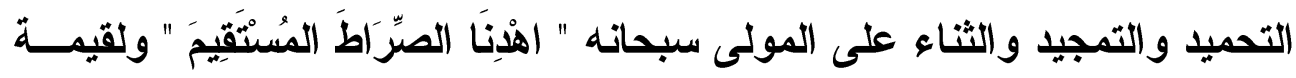

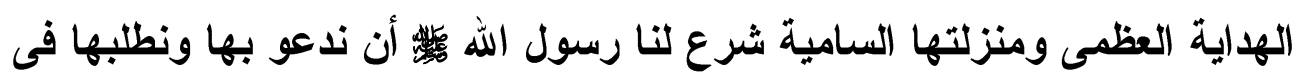

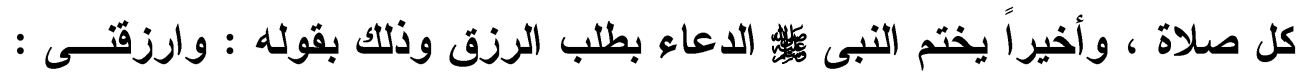
والرزق هو العطاء من الله تعالى وهو ما ينتفع به وهو ما يسوقه الله تعالى إلـى

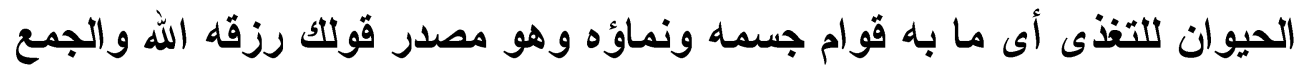

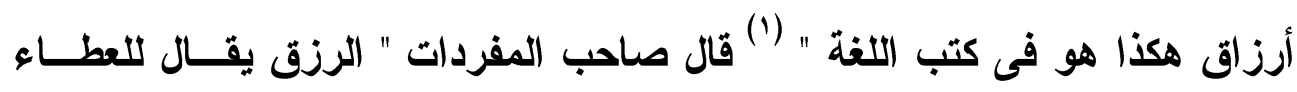

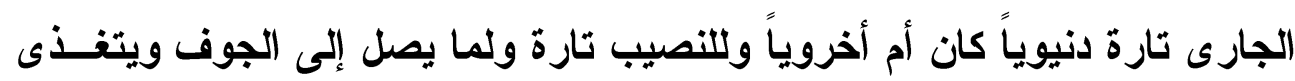

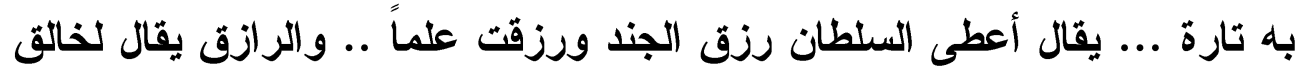

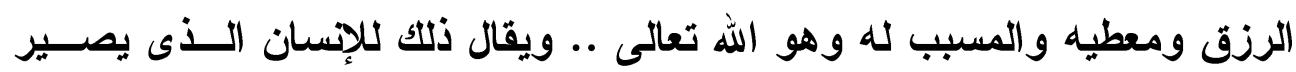

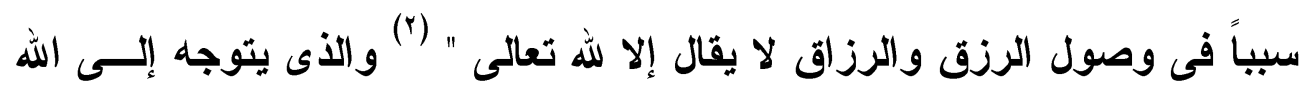

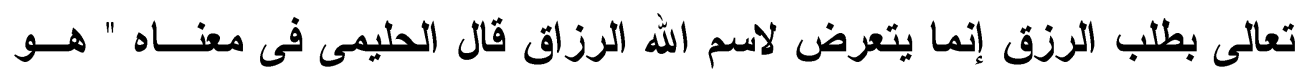

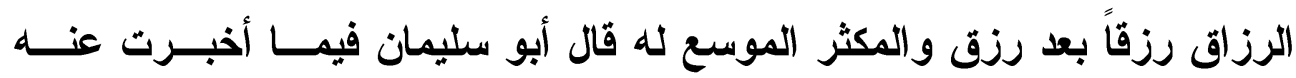
الرزاق : هو المتكفل بالرزق والقائم على كل نفس بما يقيمها من قوتها قال وكل ما وصل منه إليه من مباح وغير مباح فهو رزق الله على معنى أنه قـ جعله لــهـ

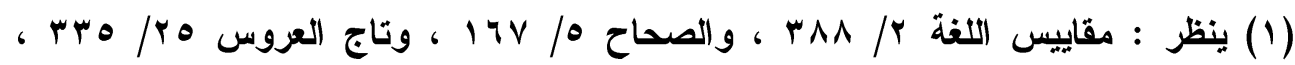

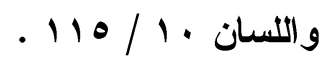


قوتاً ومعاثشاً " (") إلا أن الشيء إذا كان مأذونا له فى تناوله فهو حلال حكماً وما

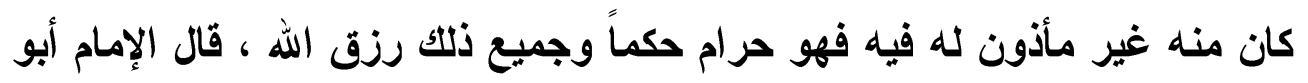

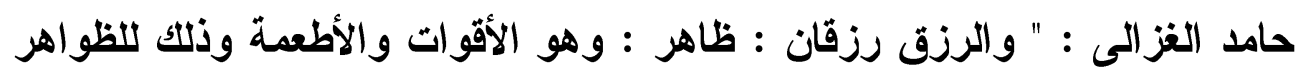

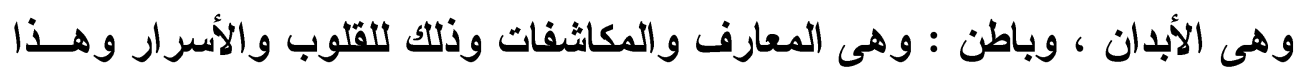

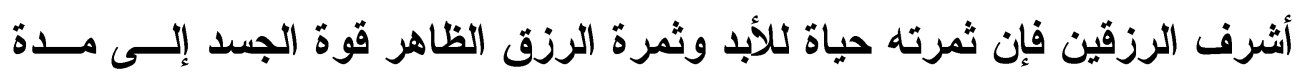

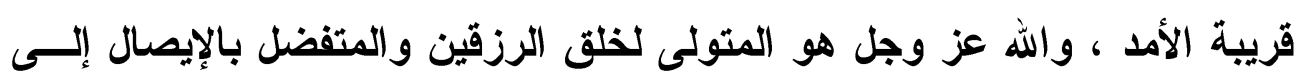

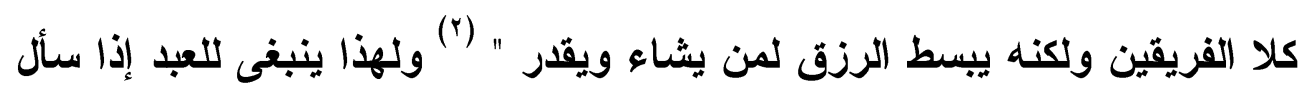

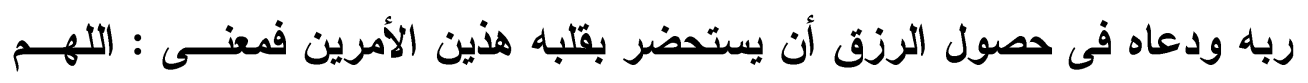

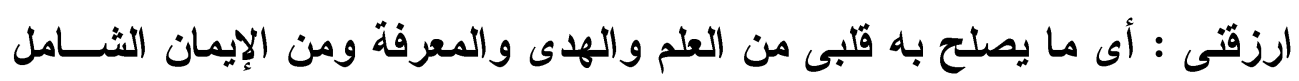

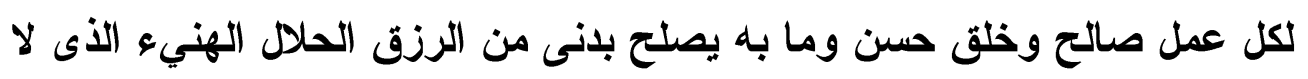

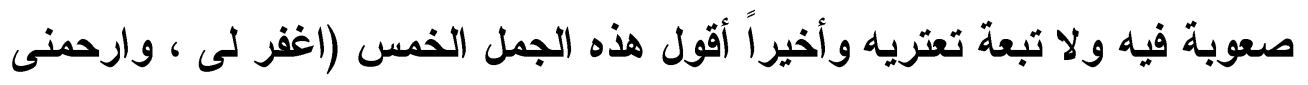

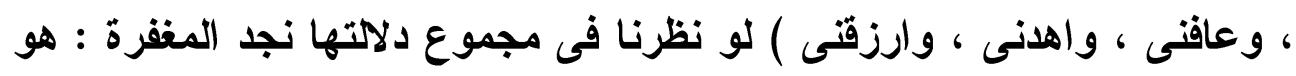

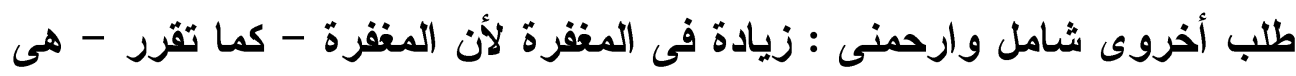

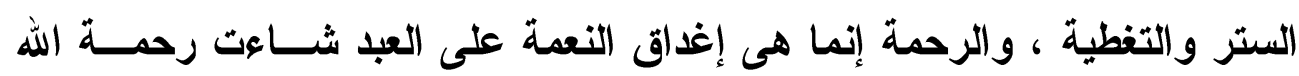

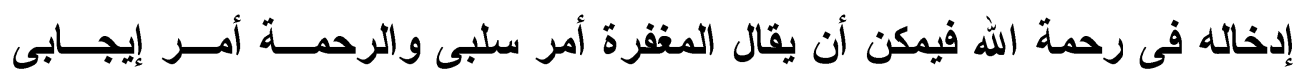

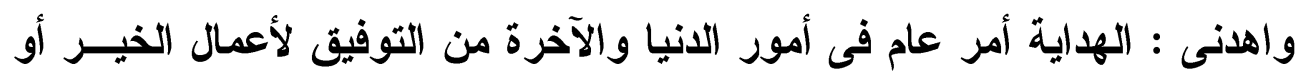

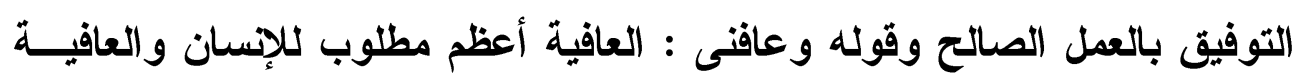

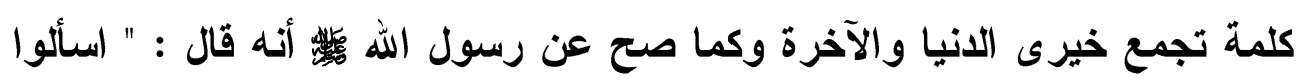

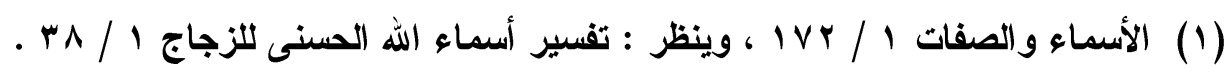

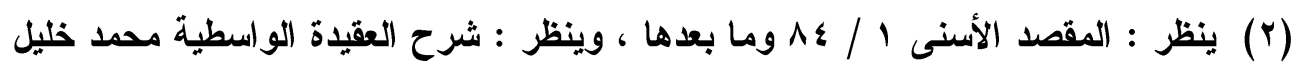

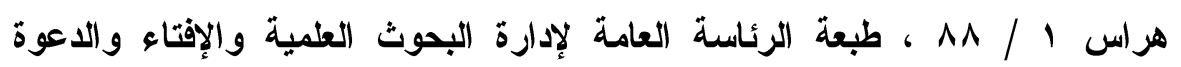

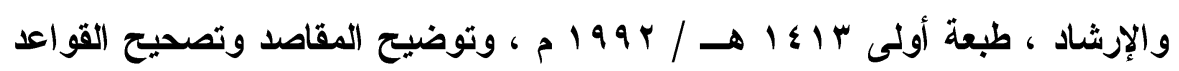

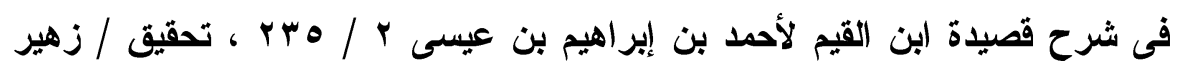

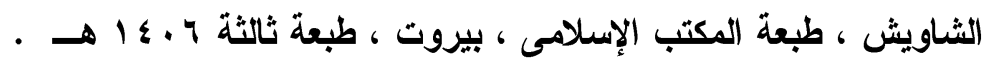




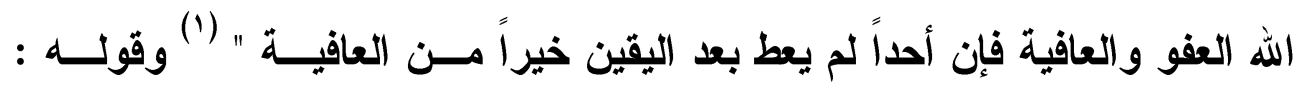

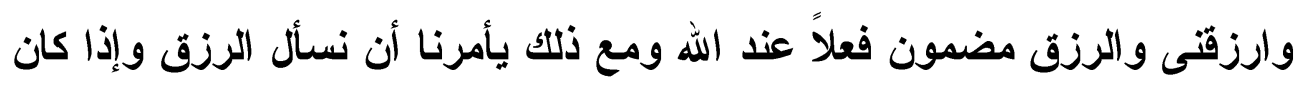

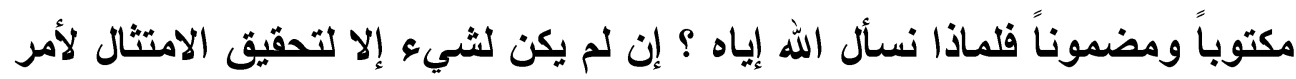
الله فيما كلفنا به لكفى ومن هنا نجد الصلاة من أولها إلى آخرها ذكر ودعاء ومن الذهن بلاغة الرسول

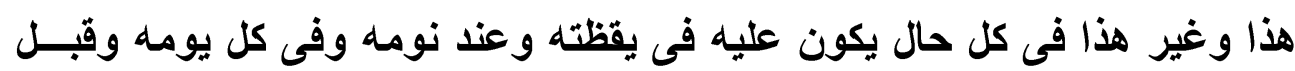
كل طاعة وفيها وبعد الفراغ منها ، وواضح وجود المناسبة بين هذه الأفعـال -

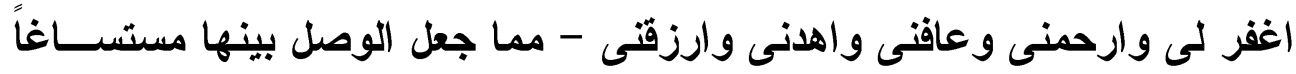

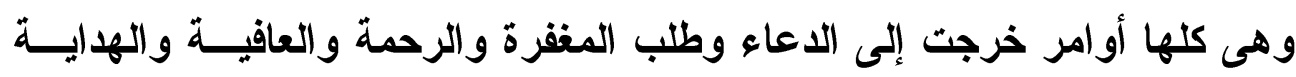

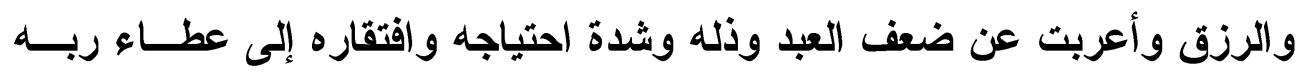

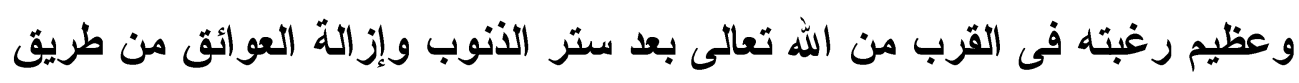

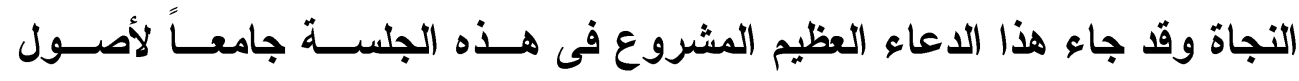

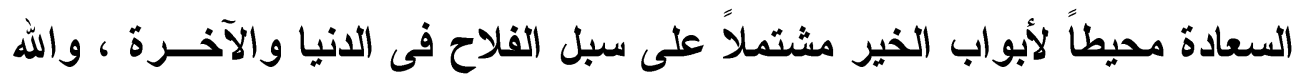

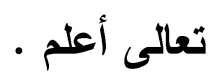

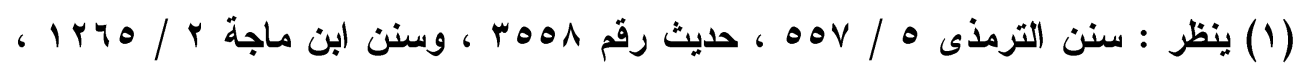

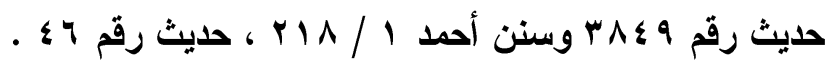




\section{المبحث السادس

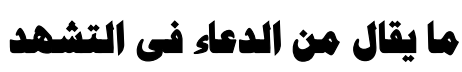

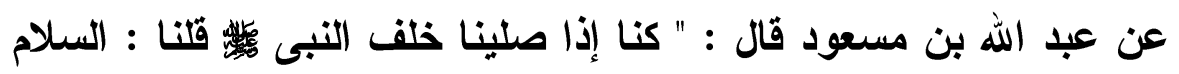

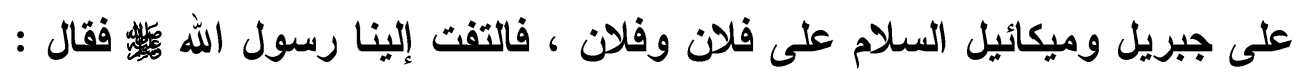

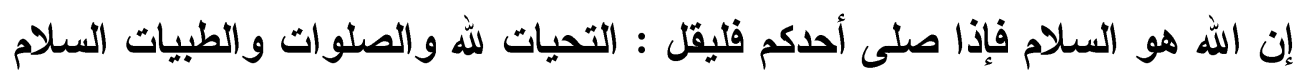

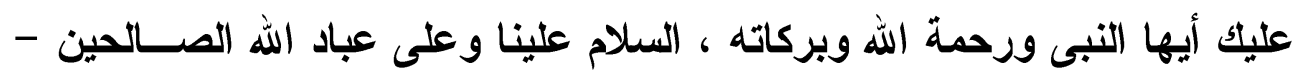

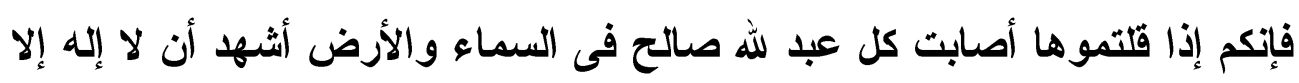

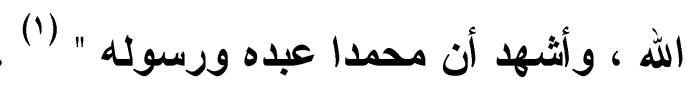

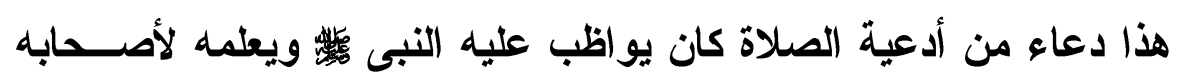

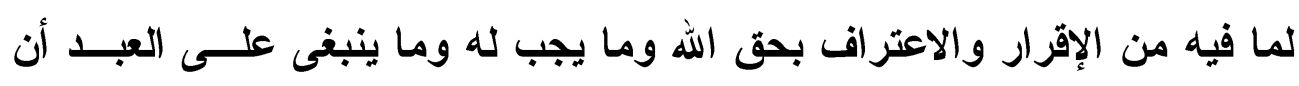

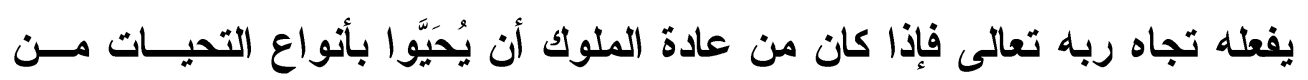

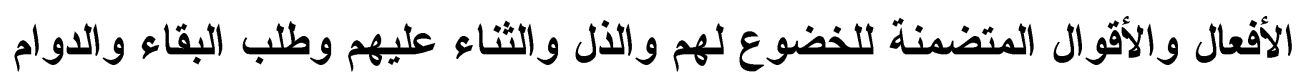

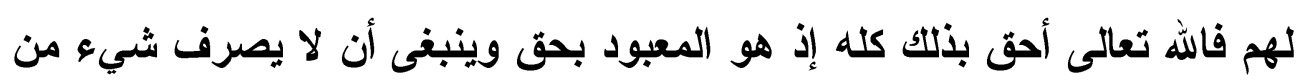

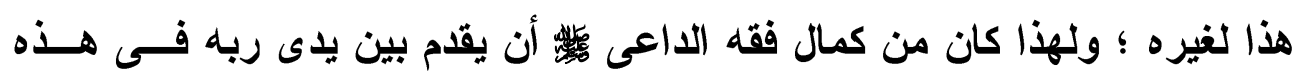

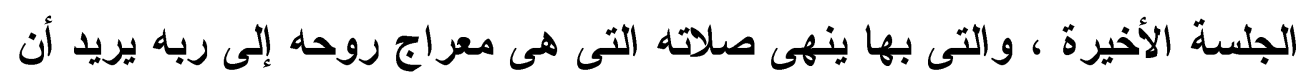

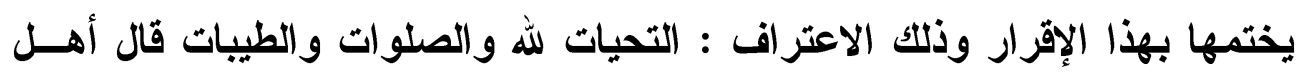

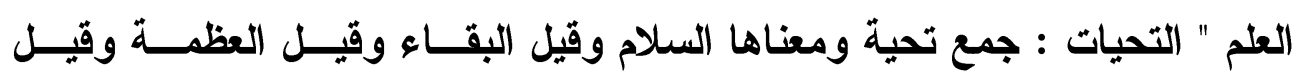

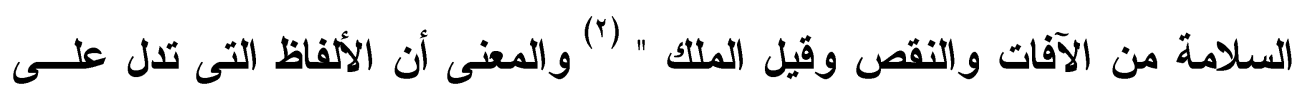

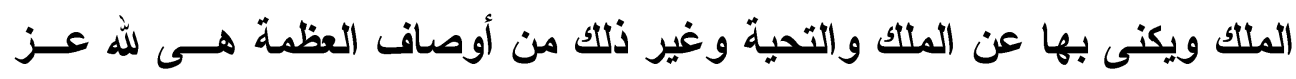

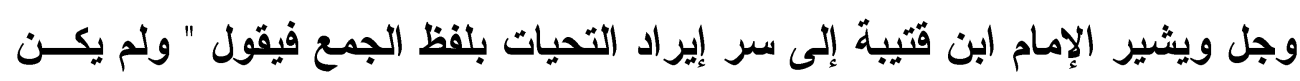

(1) صحيح البخارى ، كتاب الأدان ، باب التشه فى الآخرة ، وصحيح مسلم ، كتاب الصلاة ،

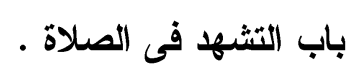

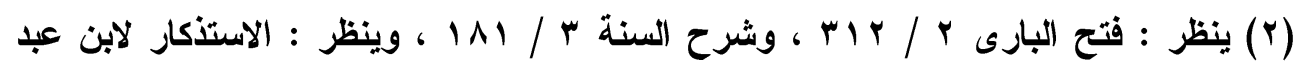

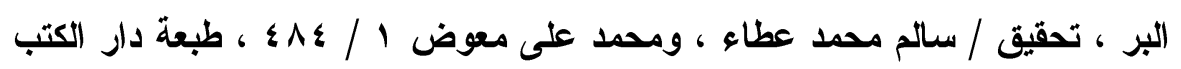

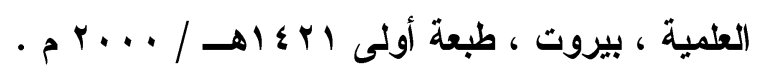


يحيا إلا الملك خاصة وكان لكل ملك تحية تخصه فلهذا جمعت " (1) وميع هذا فليس

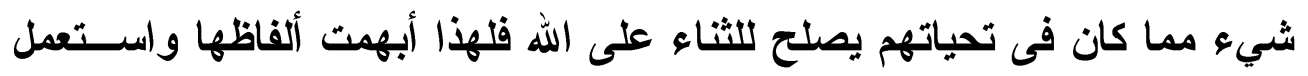

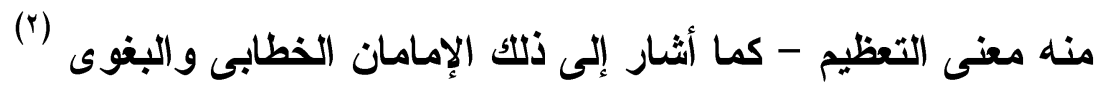

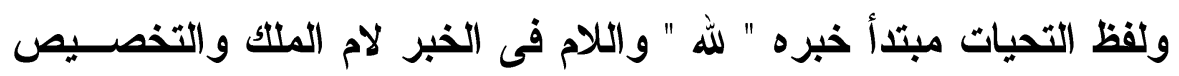

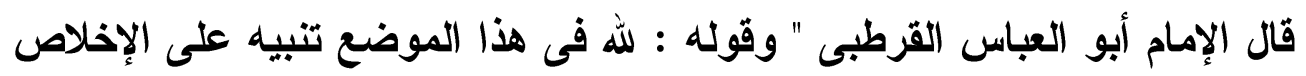

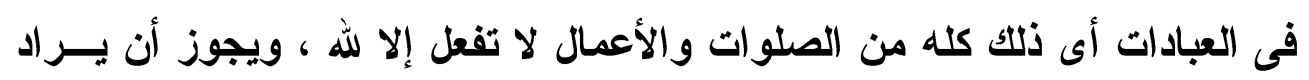

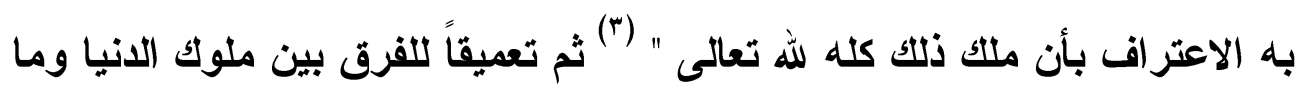

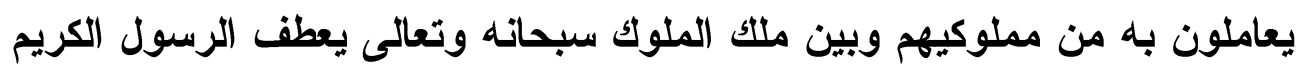

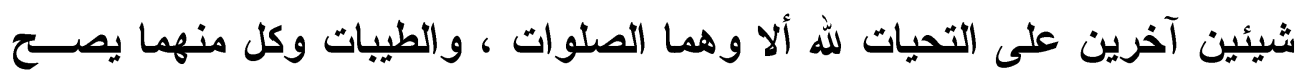

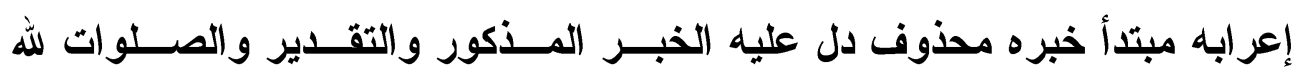

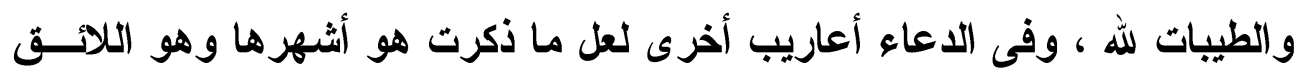

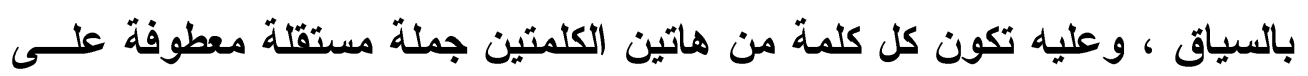

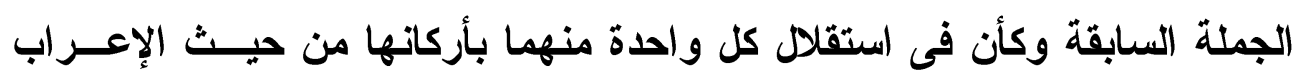

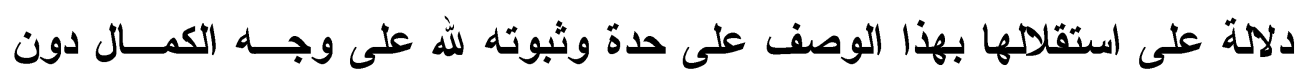

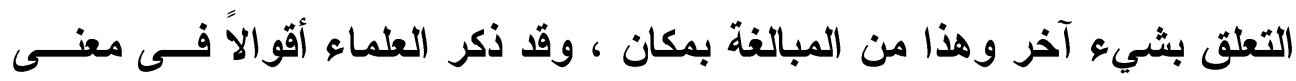

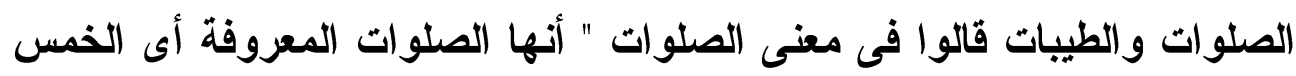

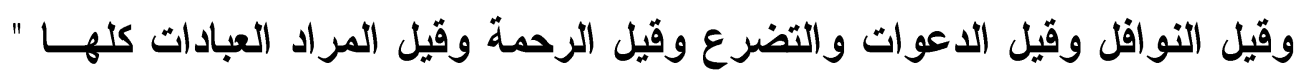

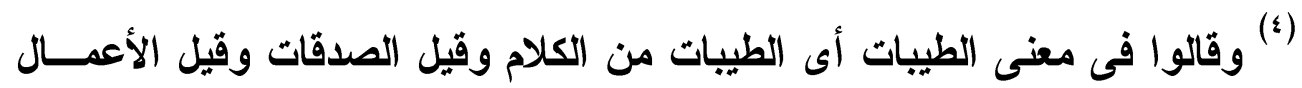

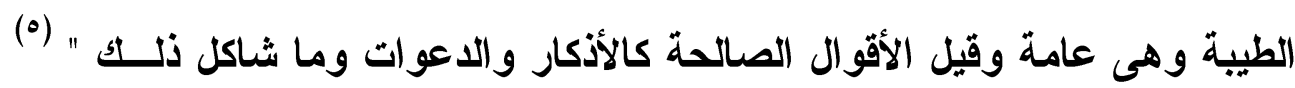

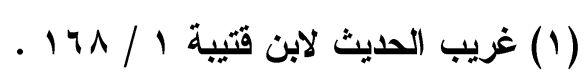

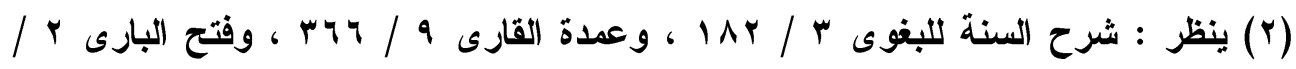

$$
\text { . rir }
$$

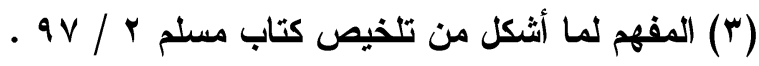

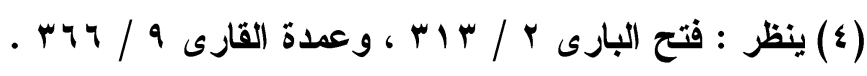

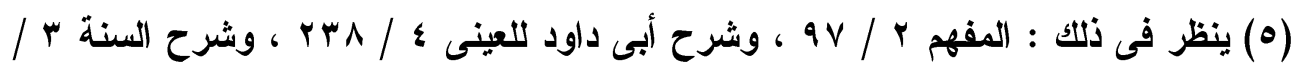


قال ابن حجر " وقيل التحيات : العبادات القولية ، والصلوات : العبادات الفعلية ،

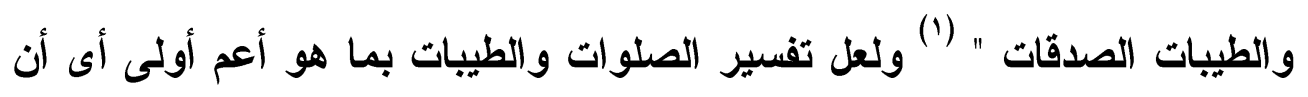

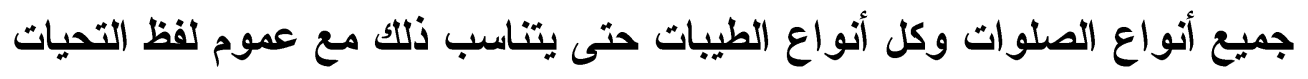

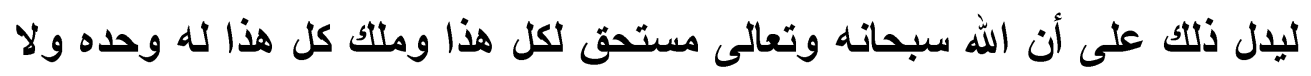

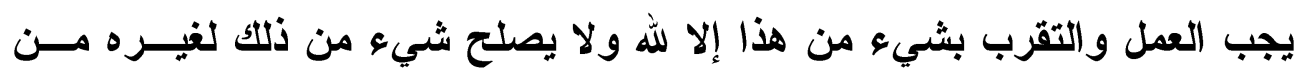

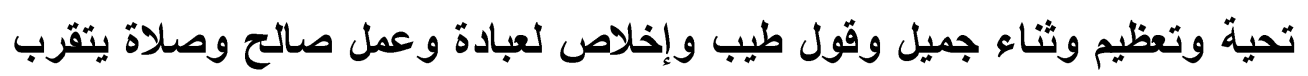

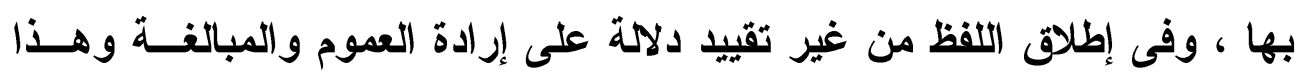

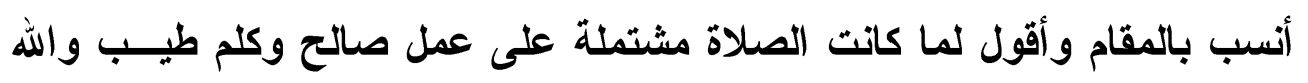

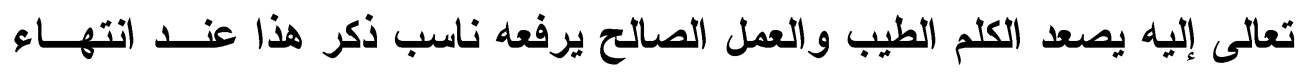

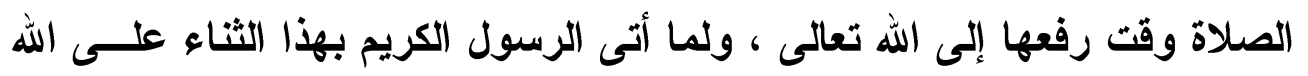

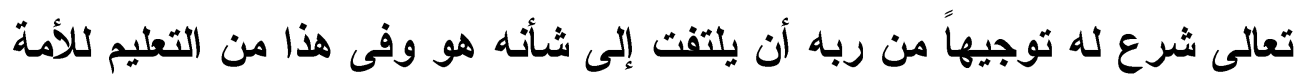

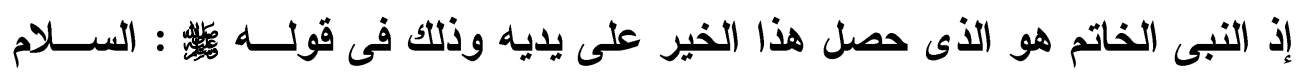

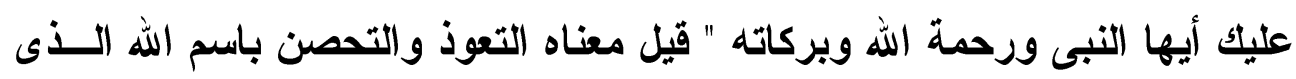

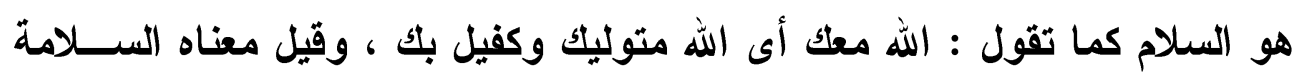

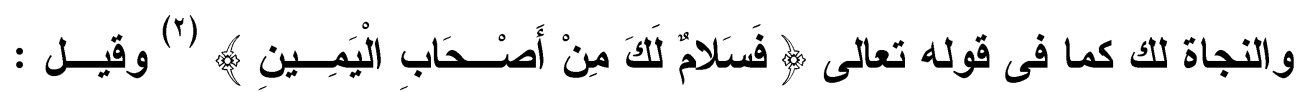

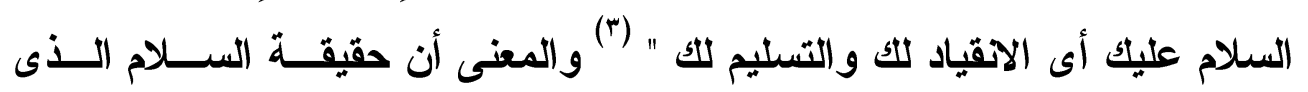

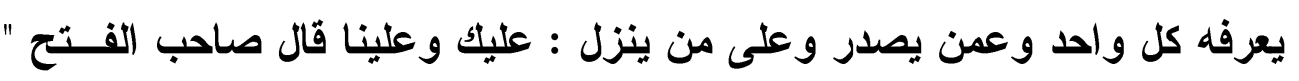

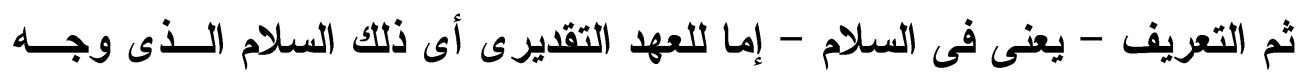

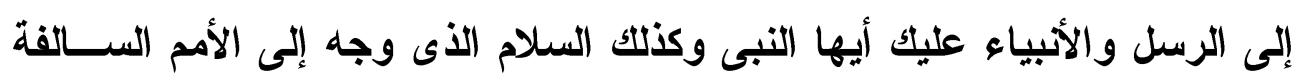

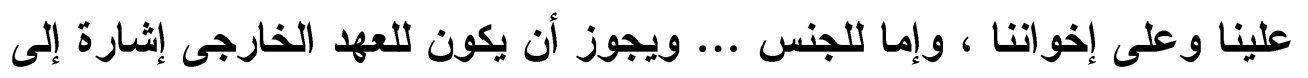

. lar

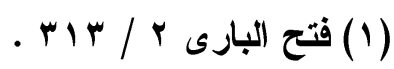

(Y)

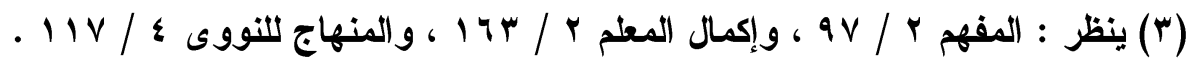




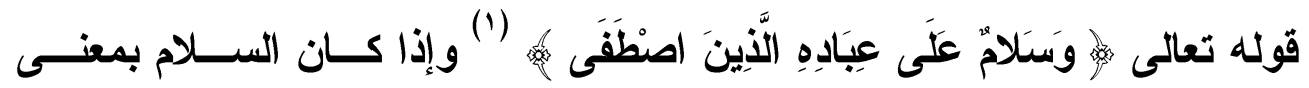

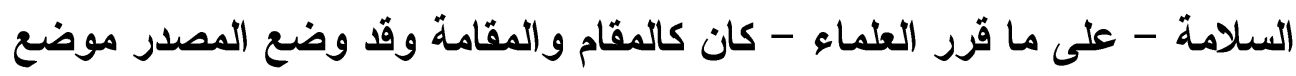

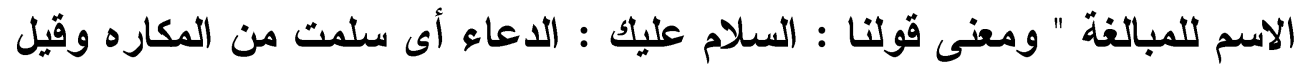

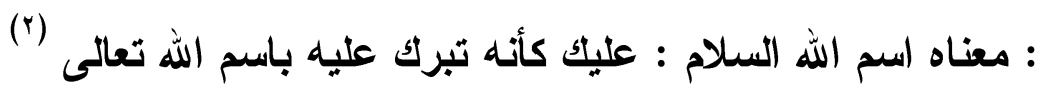

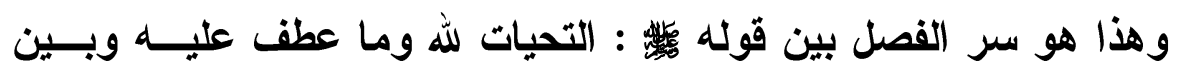

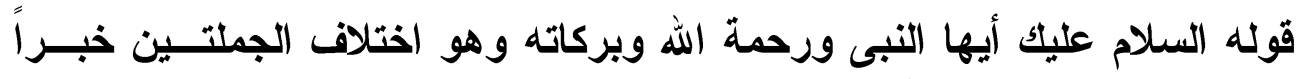

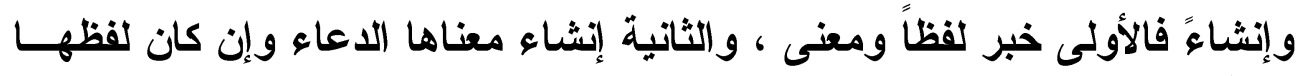

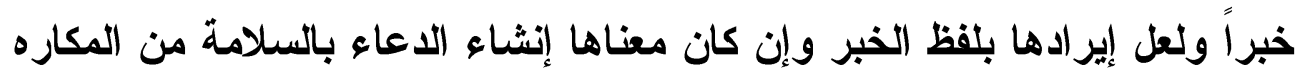

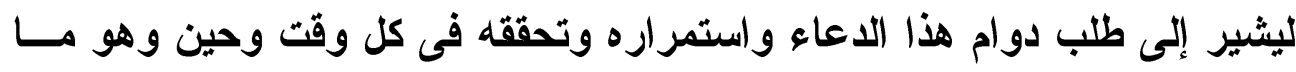

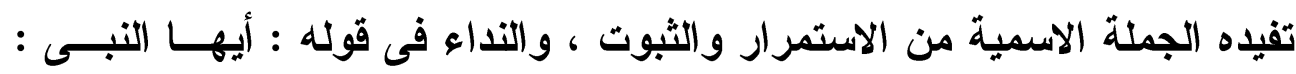

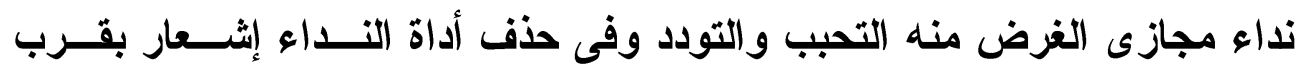

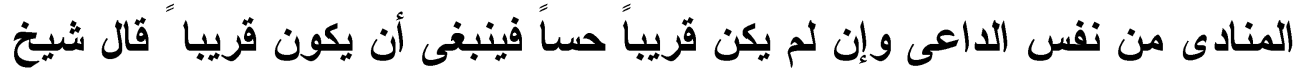

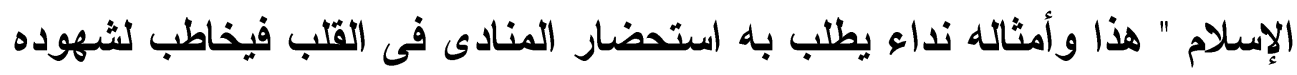

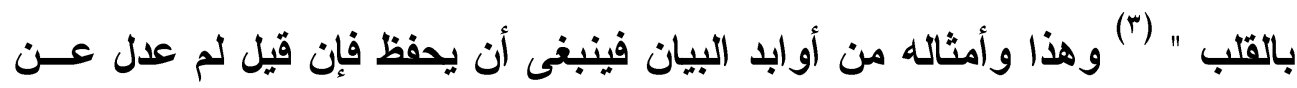

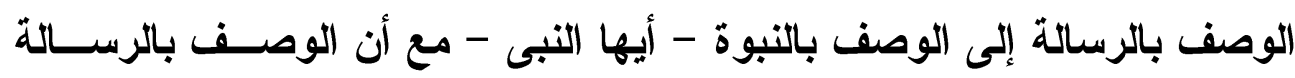

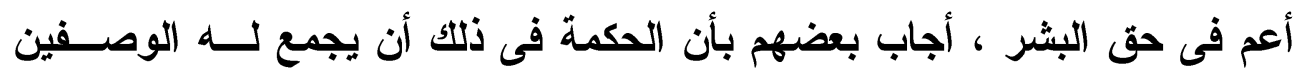

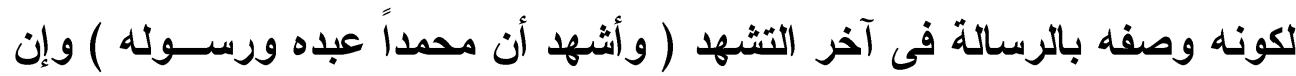

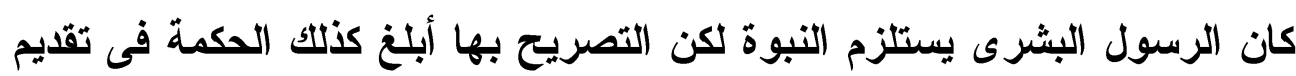

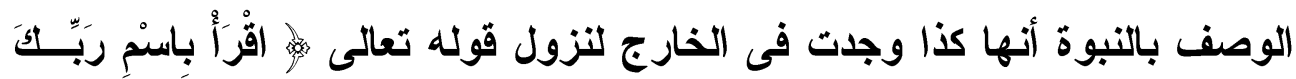

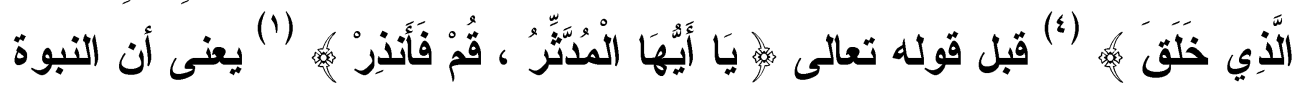

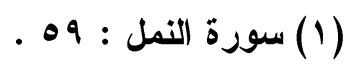

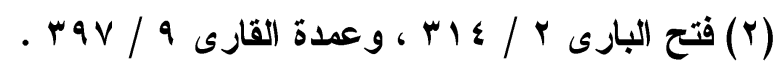

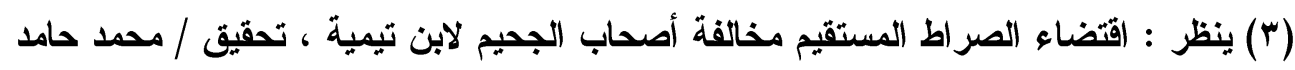

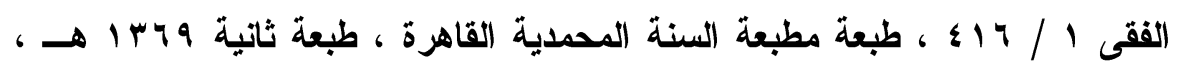

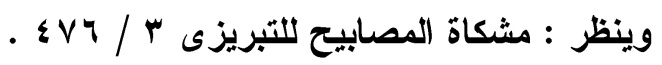


وجدت أولاً فهى سابقة للرسالة فلهذا راعى تقديم الوصف المتقدم وهذا من الدقة

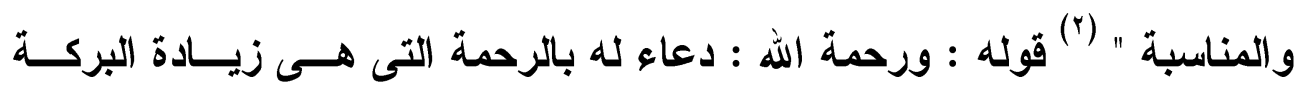

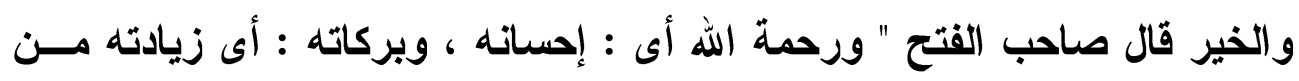

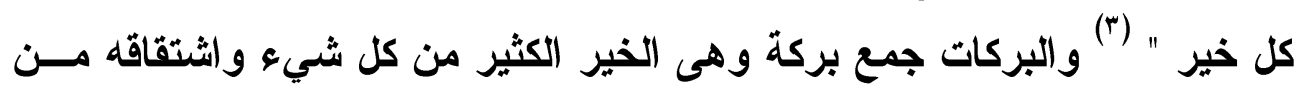

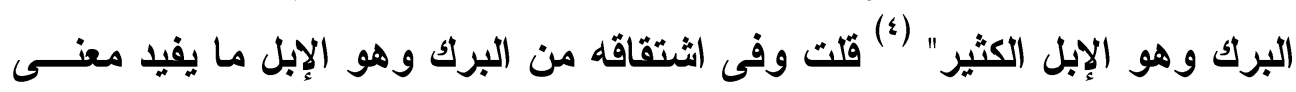

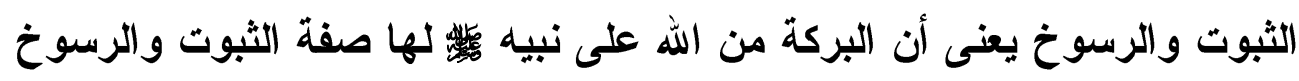

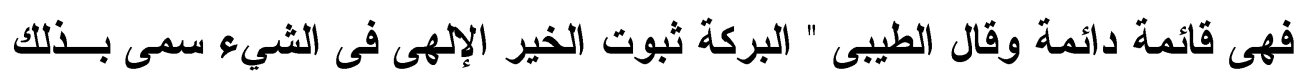

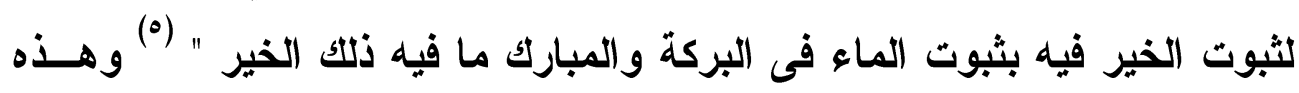

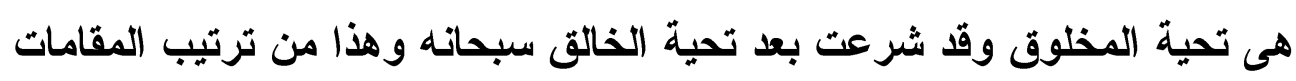

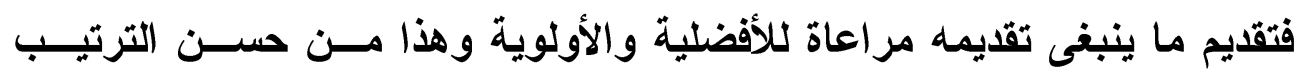

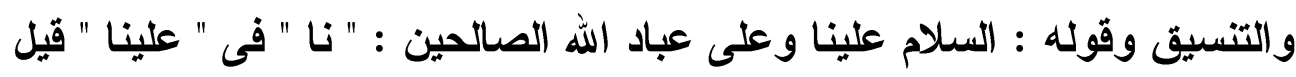

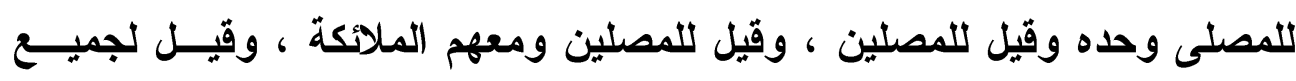

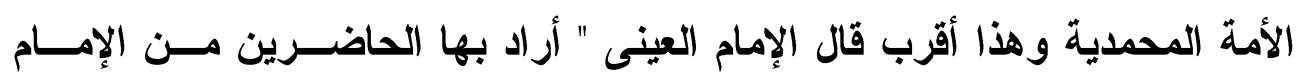

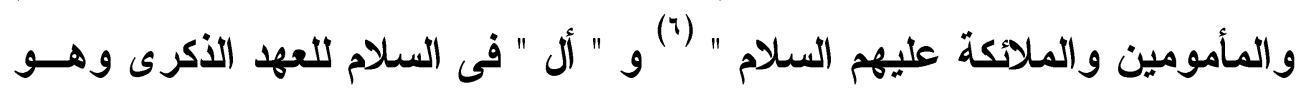

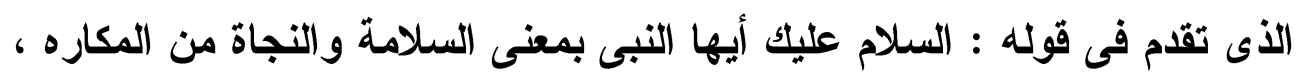

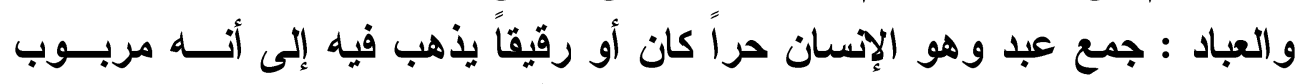

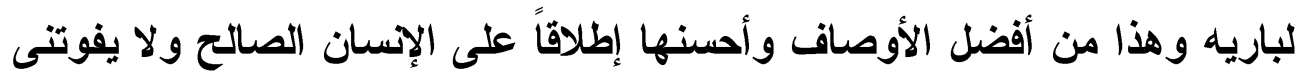

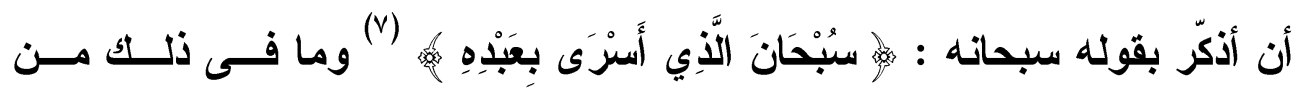

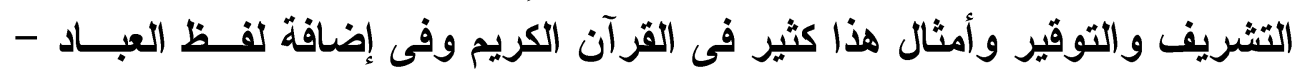

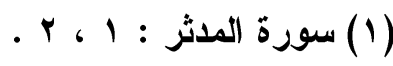

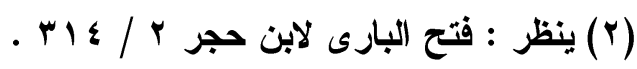

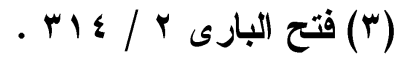

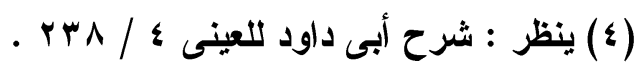

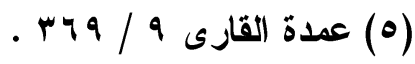

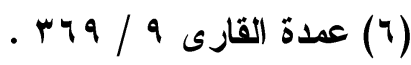

$$
\begin{aligned}
& \text { (V) }
\end{aligned}
$$


وهم أعلى درجات البشر منزلة وقربى من الله تعالى إلى لفظ ذهى الجلال " الله " ما

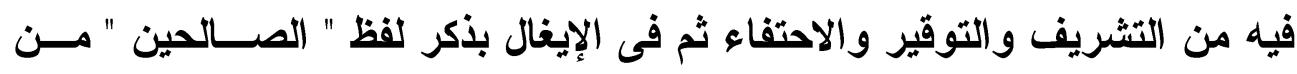

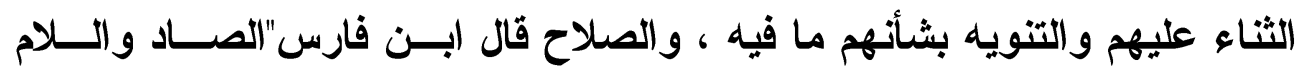

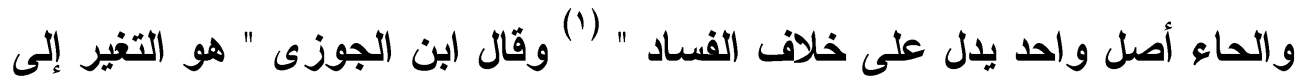

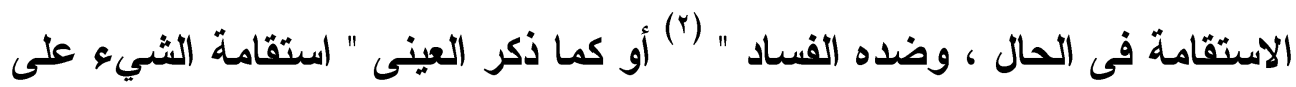

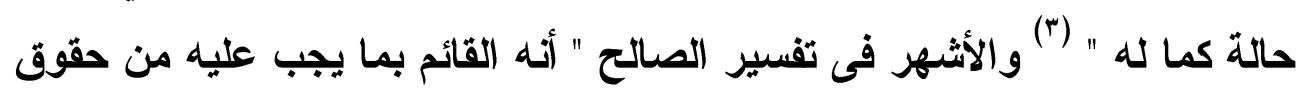

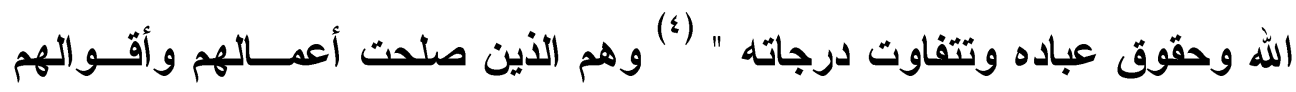

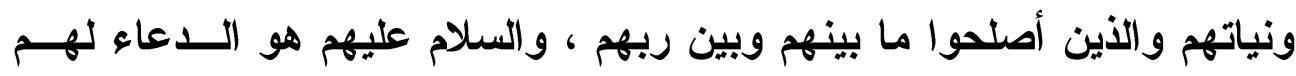

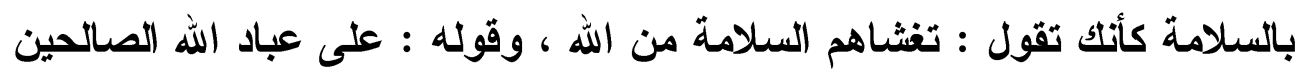

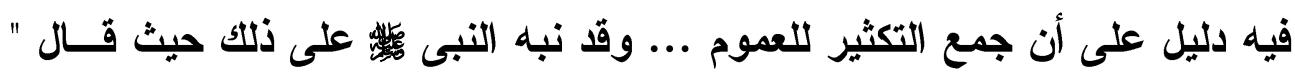

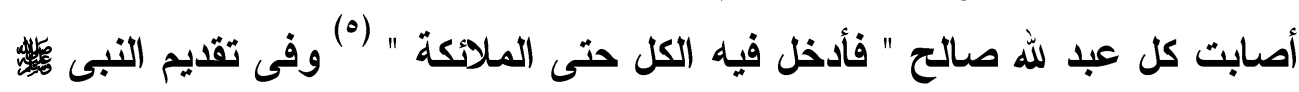

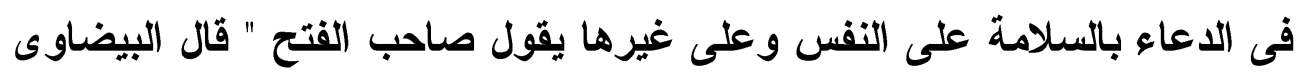

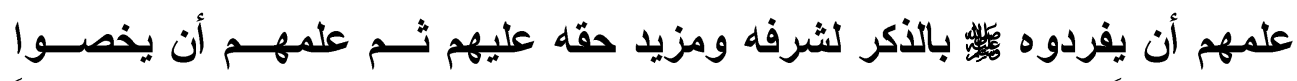

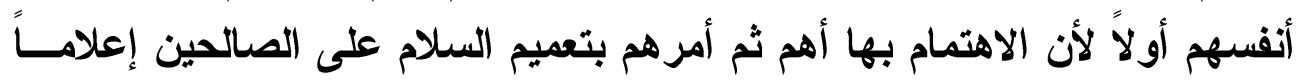

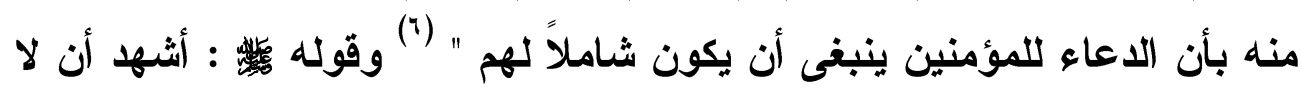

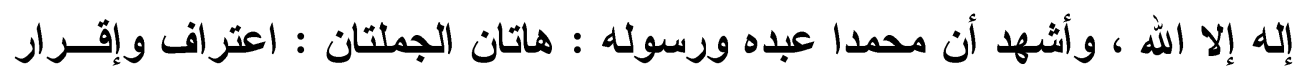

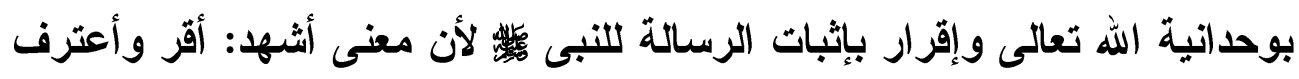

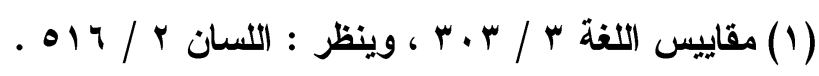

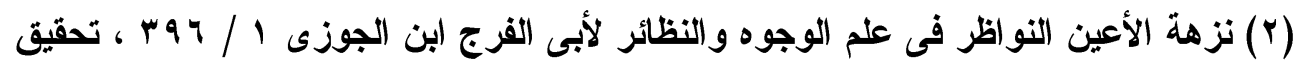

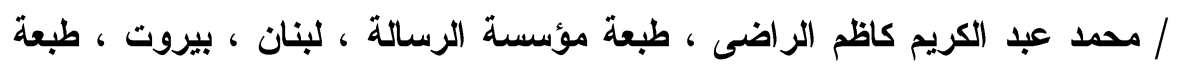

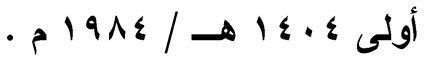

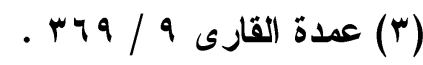

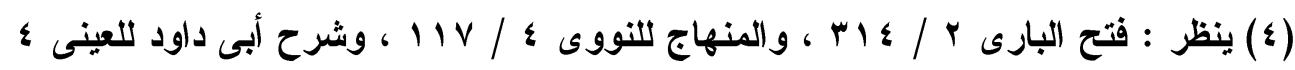
/

$$
\begin{aligned}
& \text { (0) ينظر : المفهم / (T) }
\end{aligned}
$$

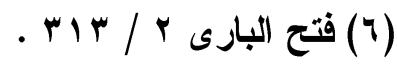




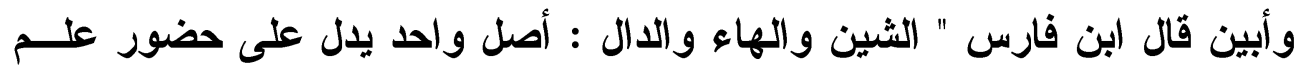

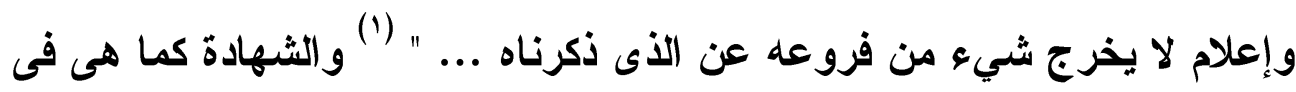

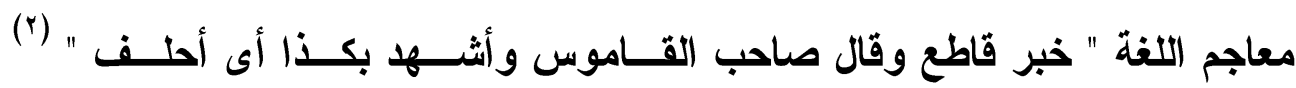

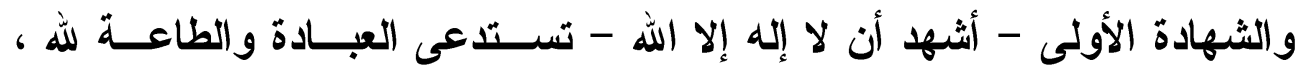

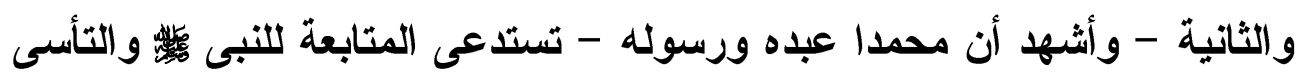

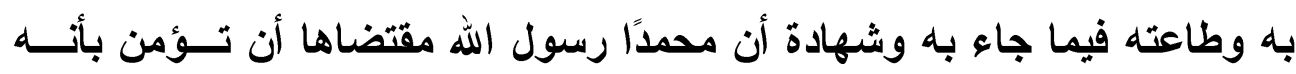

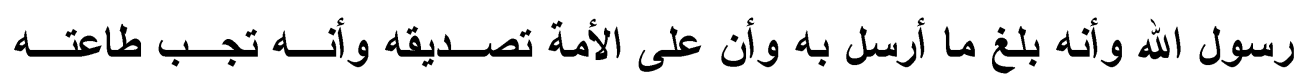

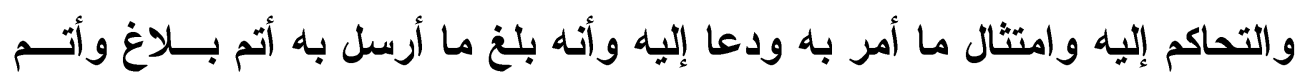

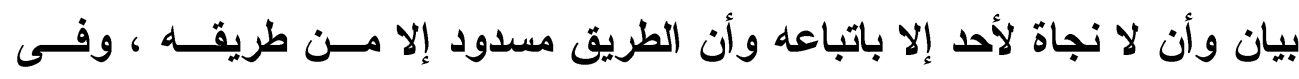

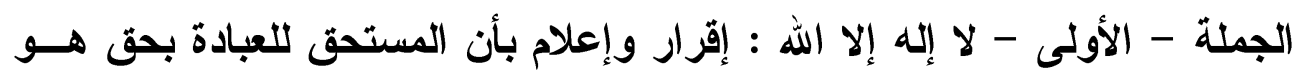

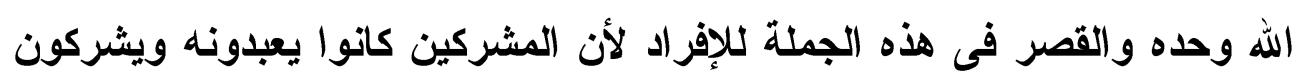

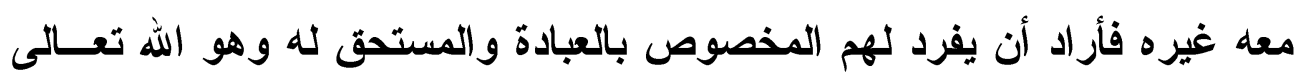

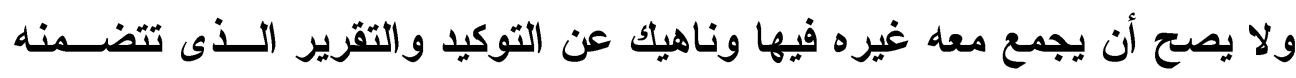

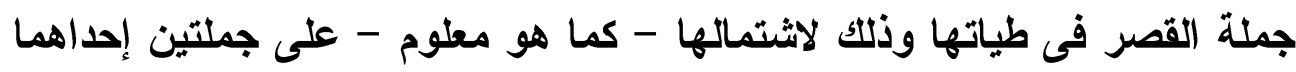

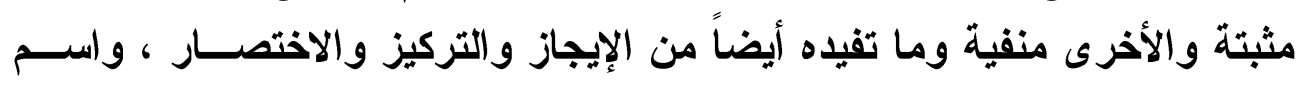

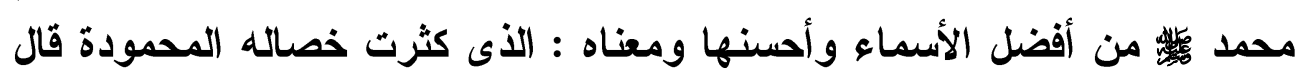

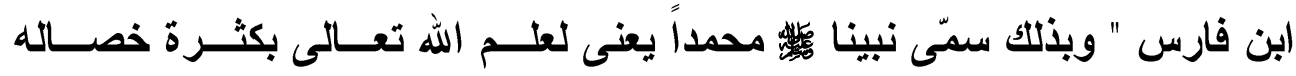

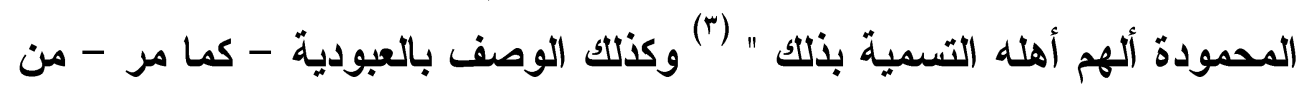

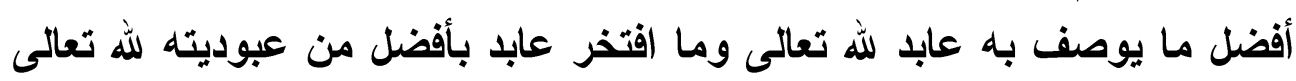

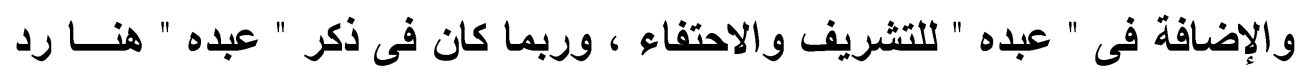

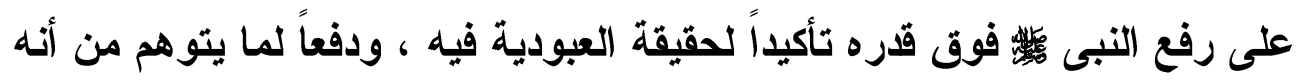

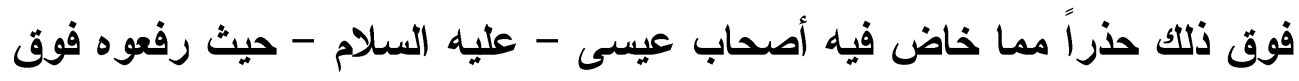

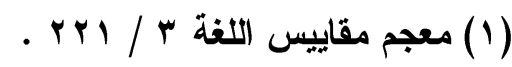

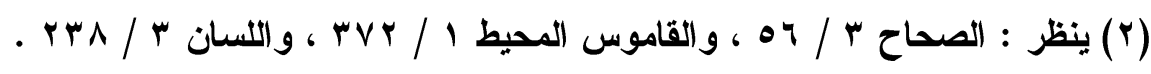

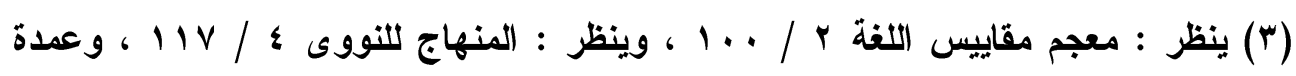

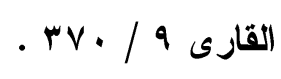


قدره وقد أكل النبى

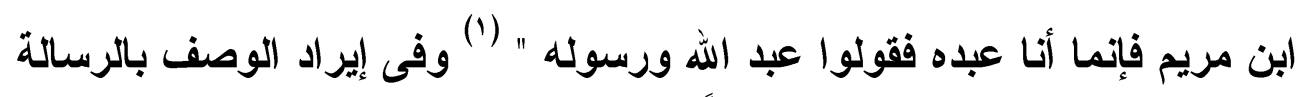

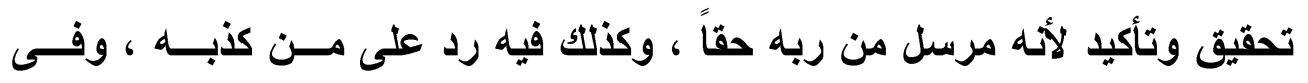

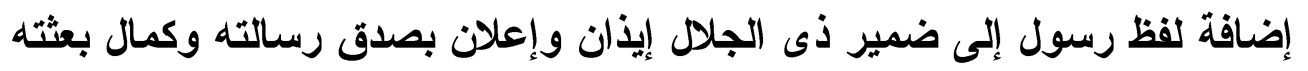

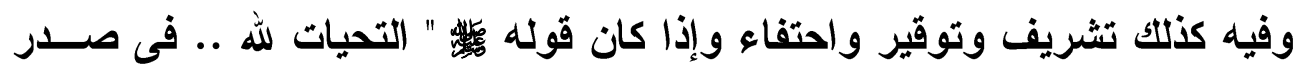

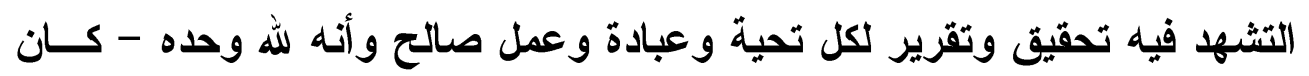

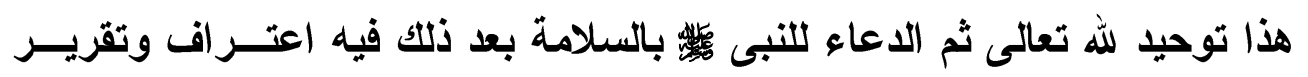

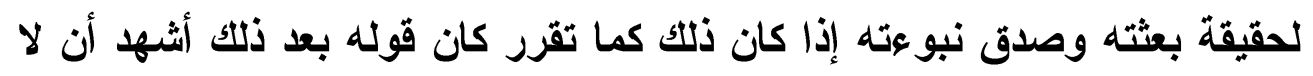

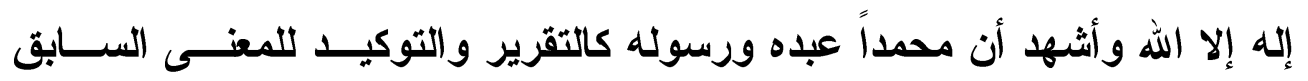

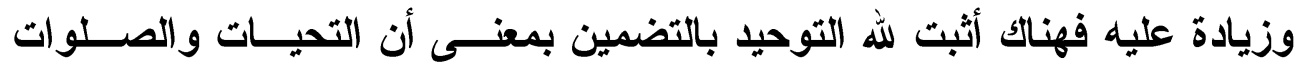

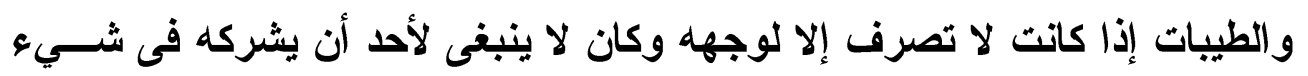

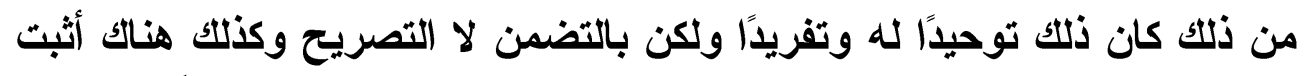

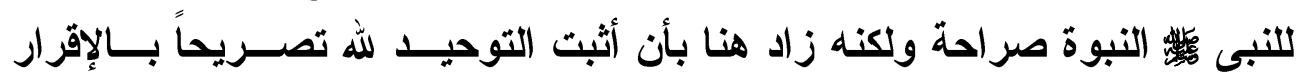

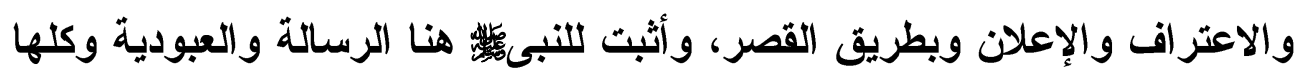

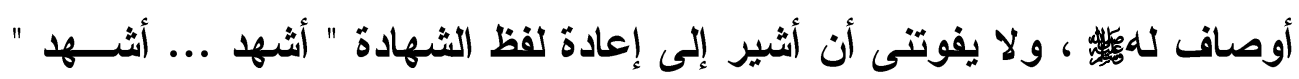

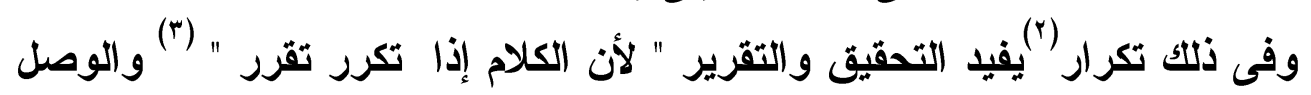

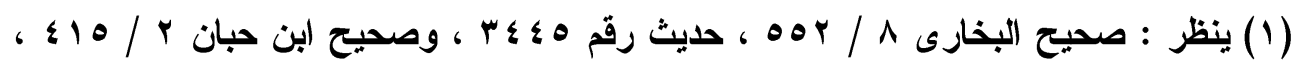

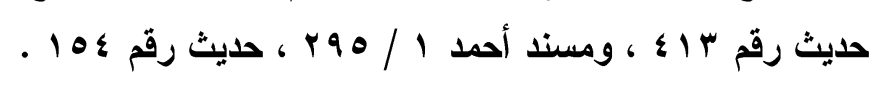

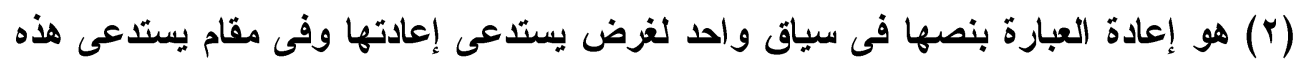

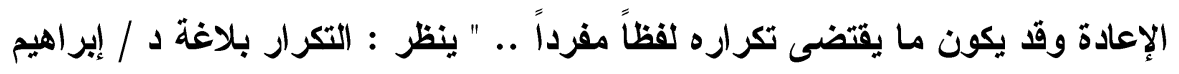

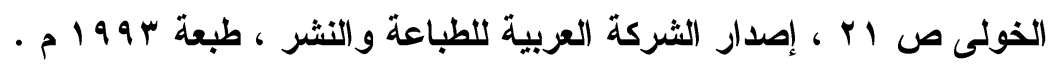

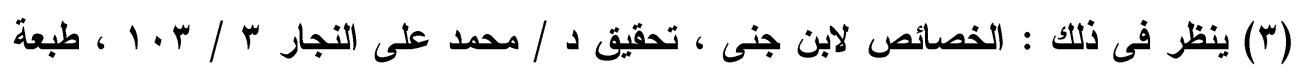

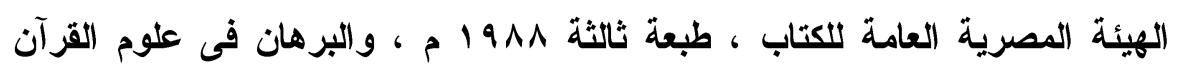

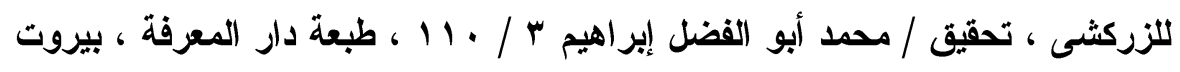

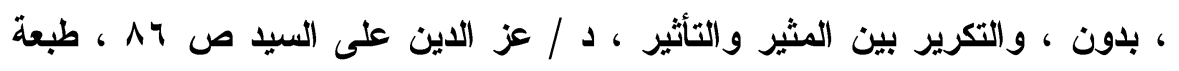

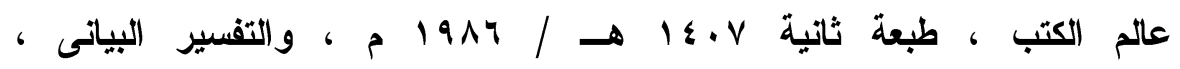


بينهما لاتفاقهما فى الخبرية لفظاً معنى " أثشهد .. و أثثه " وهو ما يسميه علماء

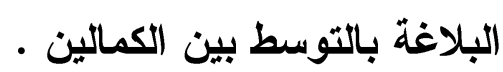

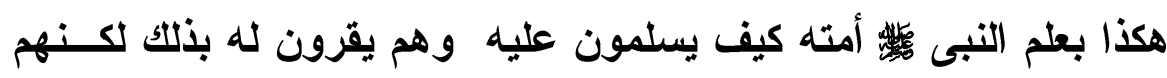

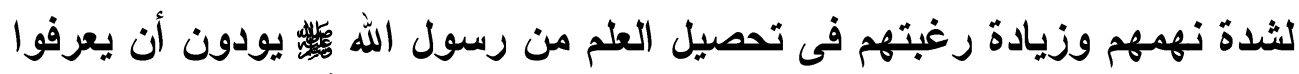

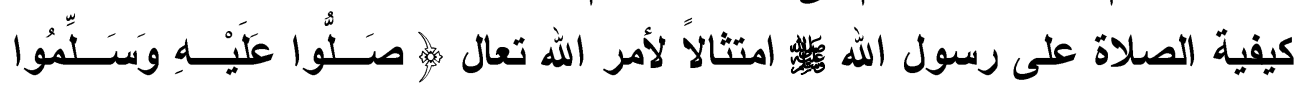

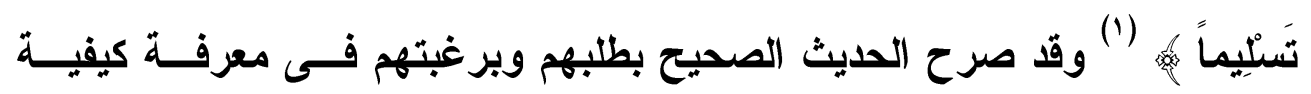

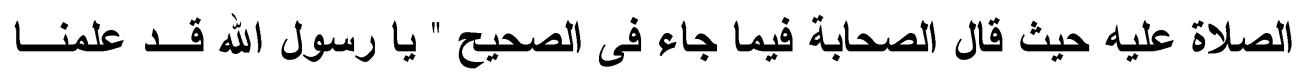

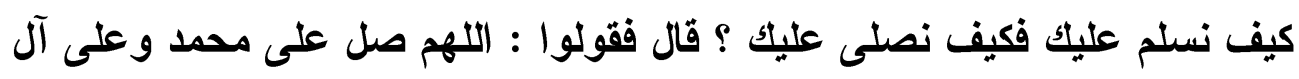

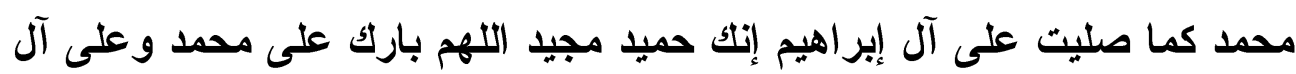

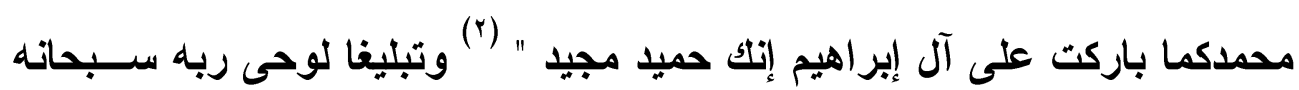

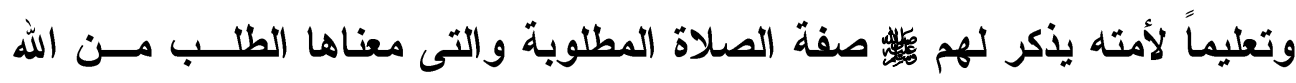

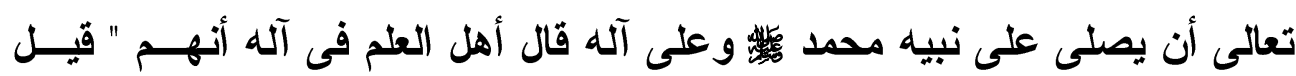

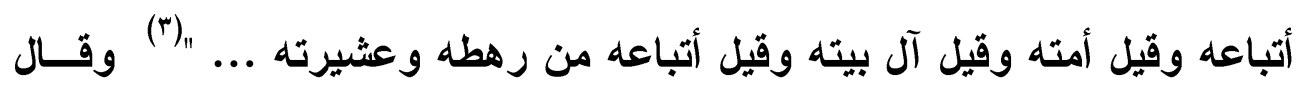

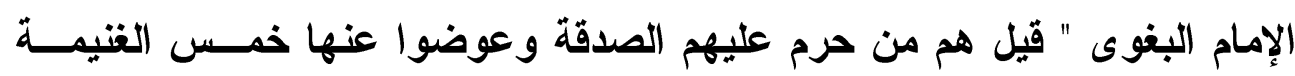

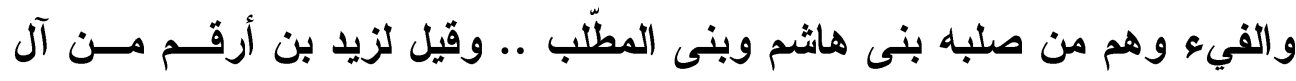

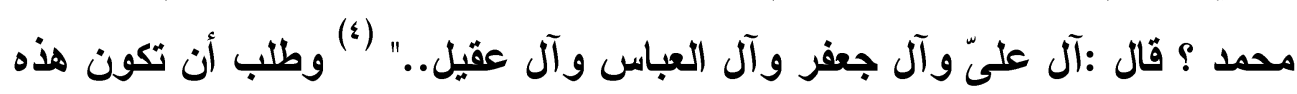

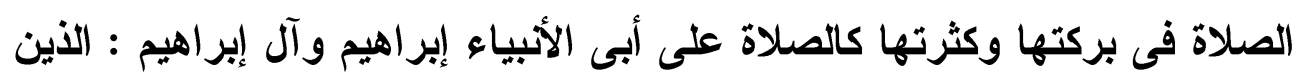

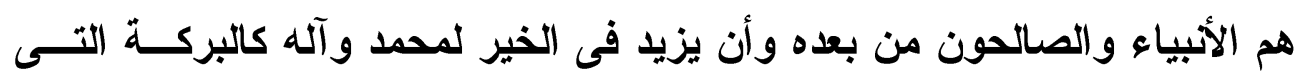

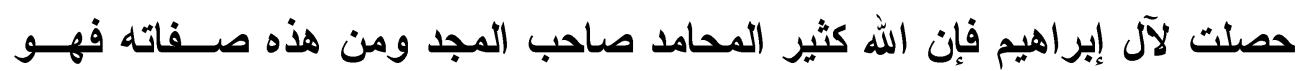

د / عائشة عبد الرحمن / / V9 ، طبعة دار المعارف بمصر ، بدون .

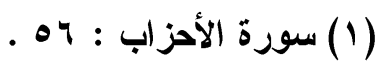

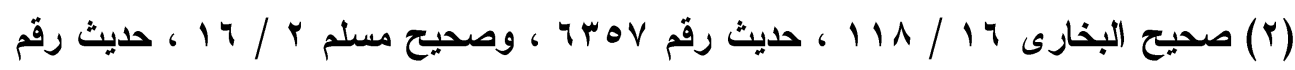
. 9ro

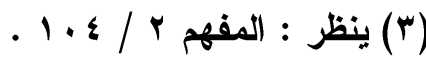

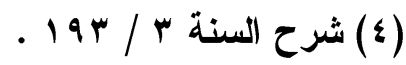


قريب العطاء واسع النوال ويستهل هذا الطلب بالنداء الذى يجمع كـل الأســـاء

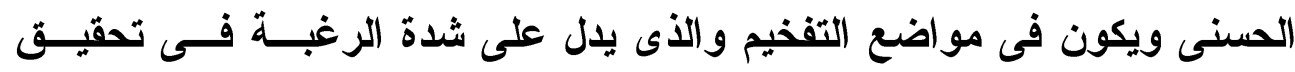

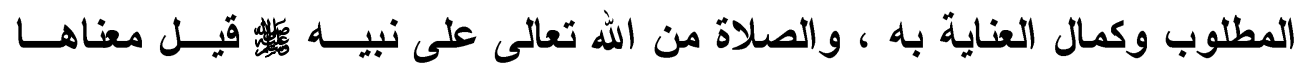

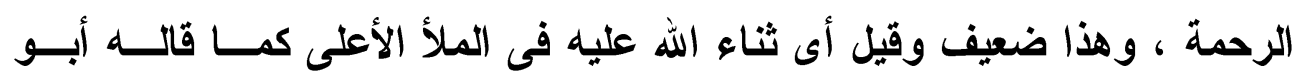

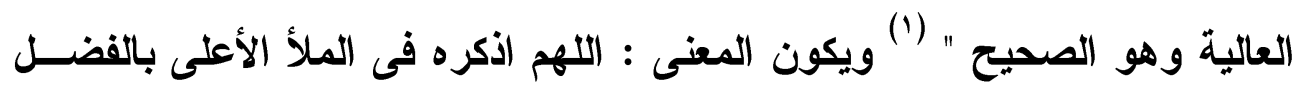

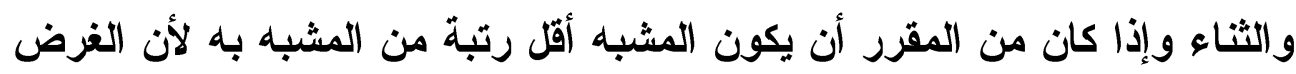

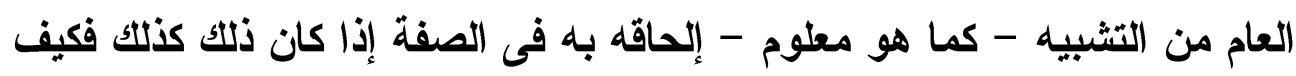

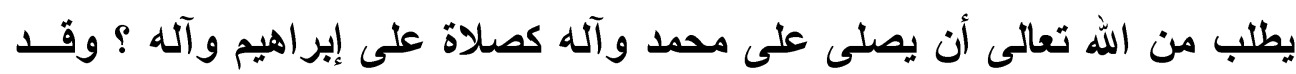

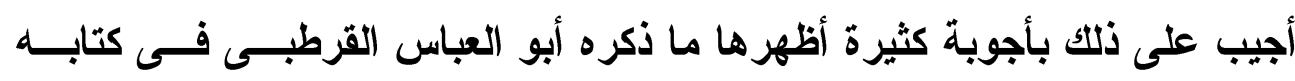

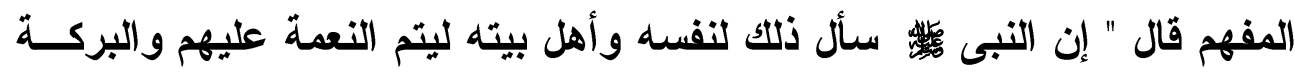

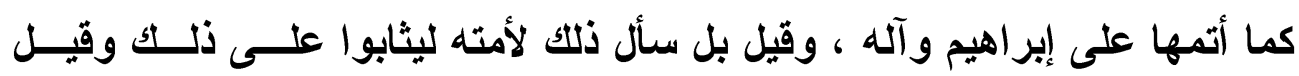

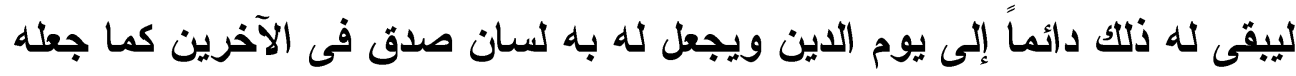

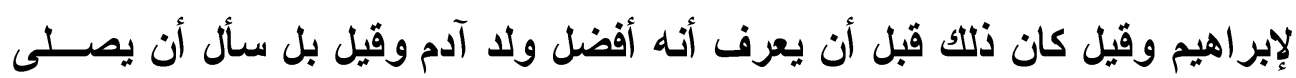

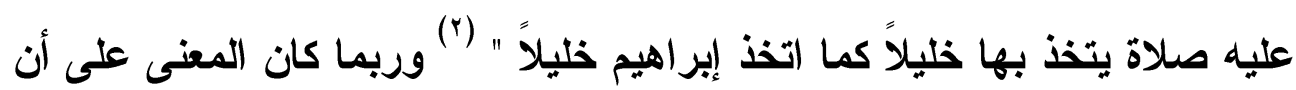

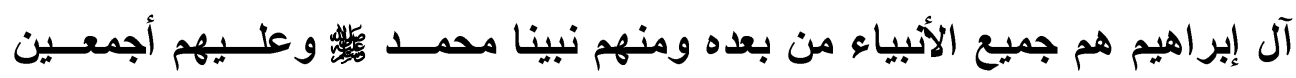

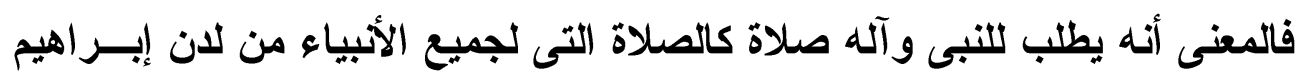

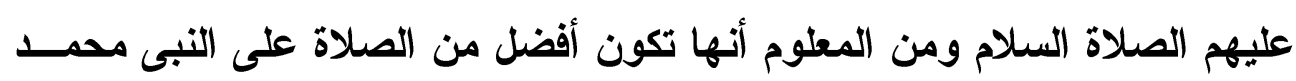
• أما قوله : إنك حميد مجيد : " فالحميد فعيل من الحمد وهو بمعنى محمود

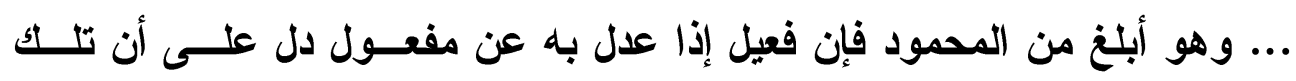

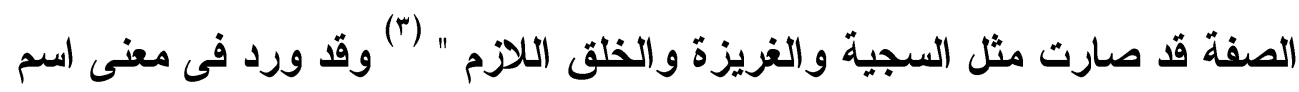

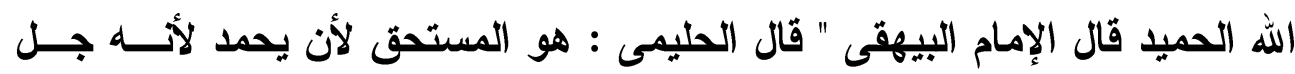


ثناؤه بدأ فأوجد ثم جمع بين النعمتين الجليلتين الحياة و العقل ووالى بعـــ منحسـه

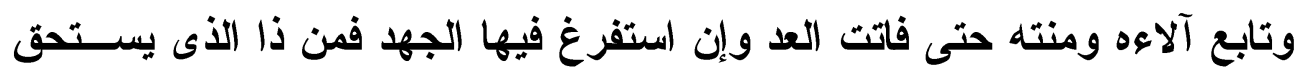

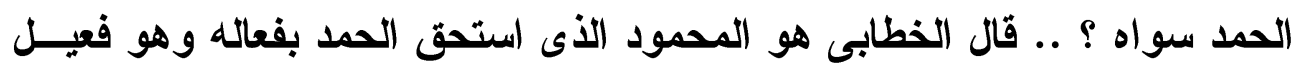

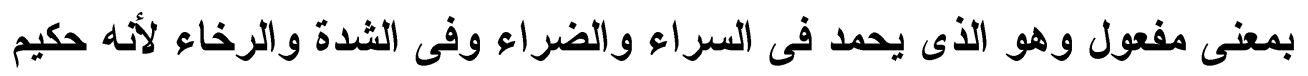
لا يجرى فى أفعاله الغلط ولا يعترضه الخطأ فهو محمود على كل حال " (1) وقـــال

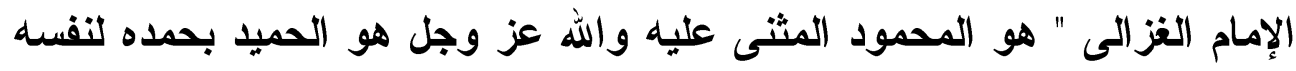

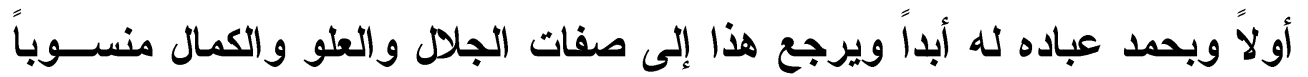

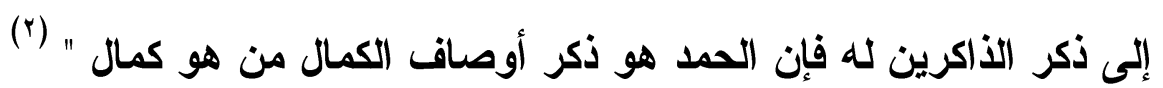

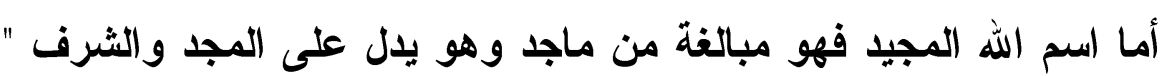

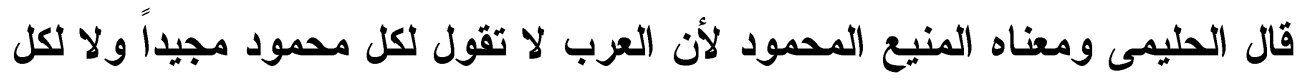

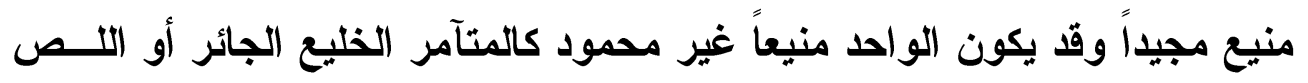

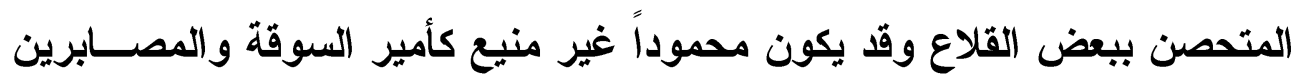

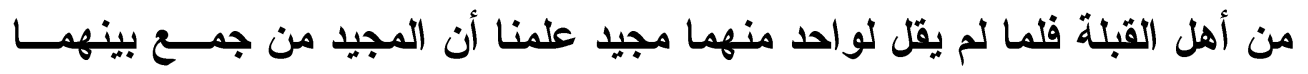

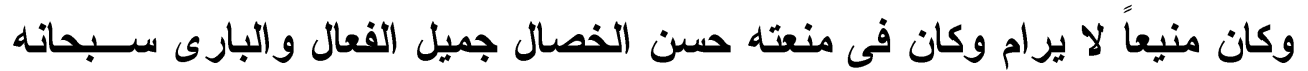

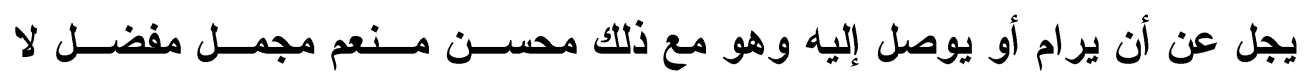

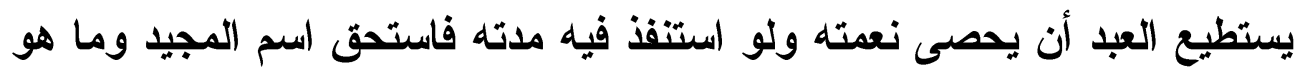

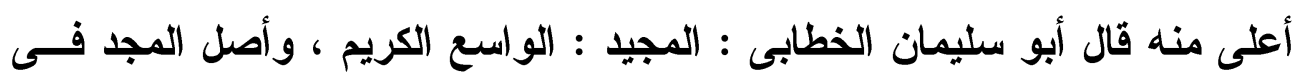

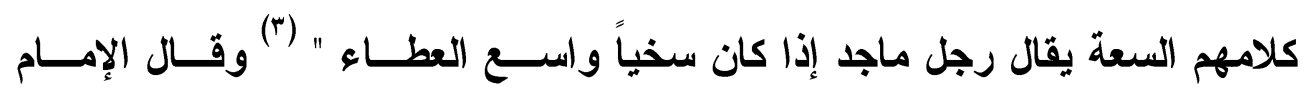
الغزالى " هو الثريف ذاته الجميل أفعاله الجزيل عطاؤه ونو الذه فكأن شرف الذاء الذات الذات

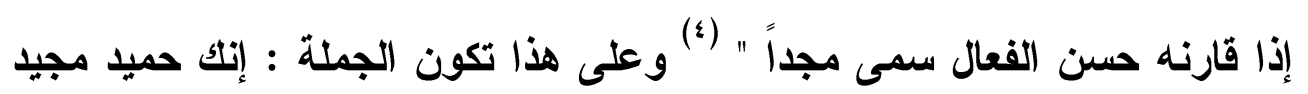

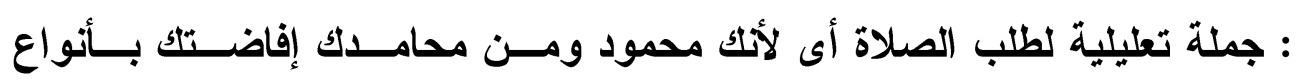

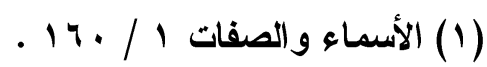

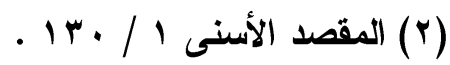

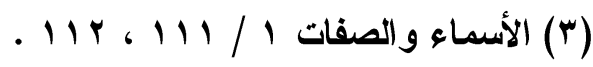

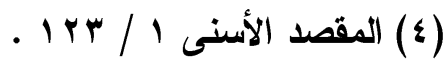


العنايات وزيادة البركات على نبيك الذى تقرب إليك بامتثال ما أهلته له مـن أداء

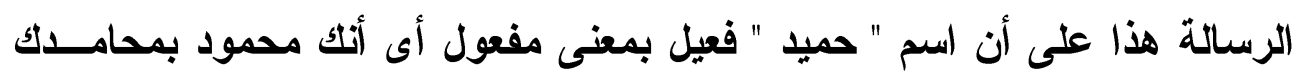

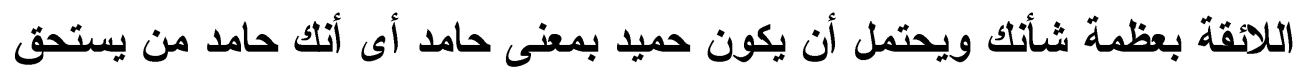

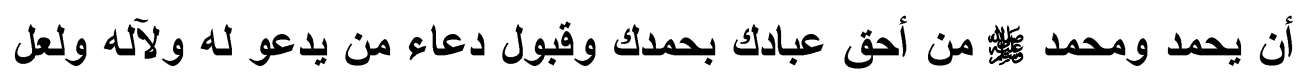

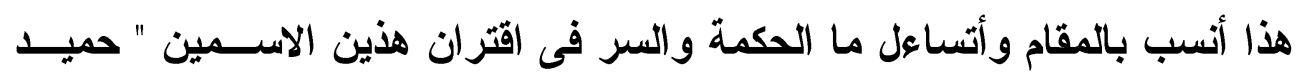

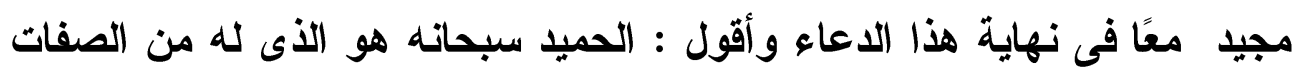

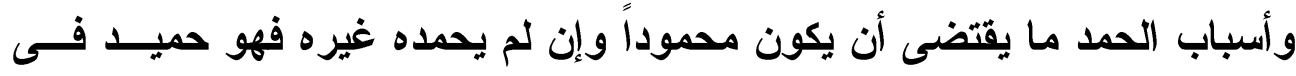

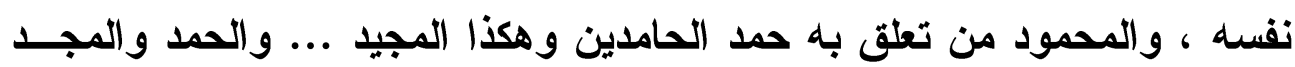

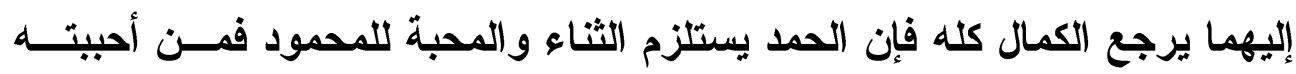

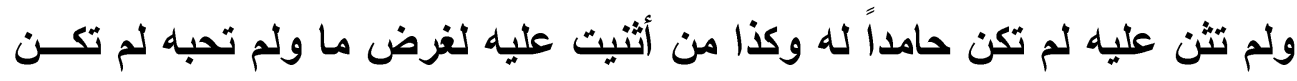

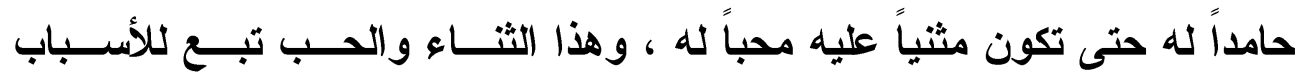

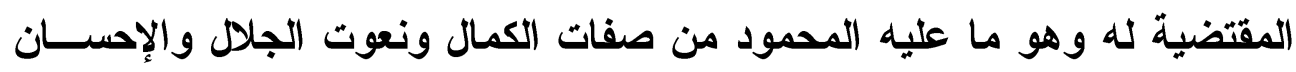

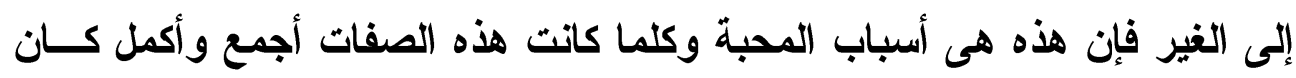

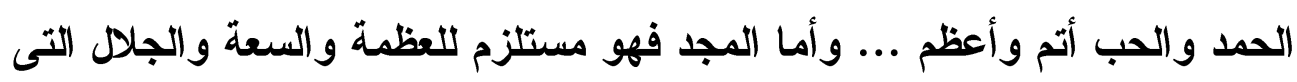

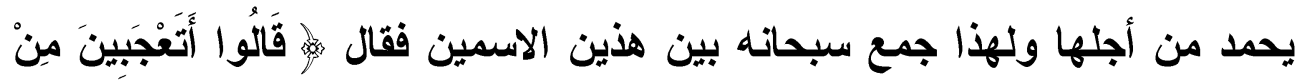

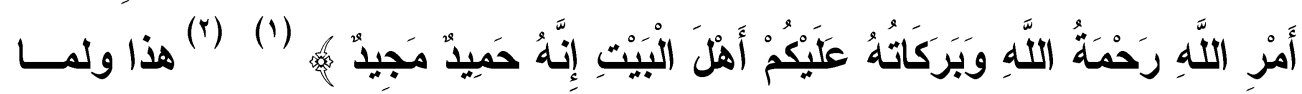

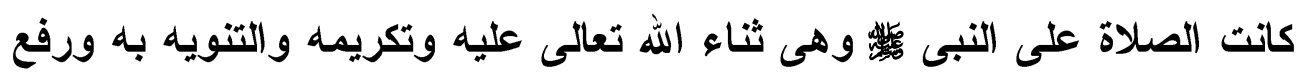

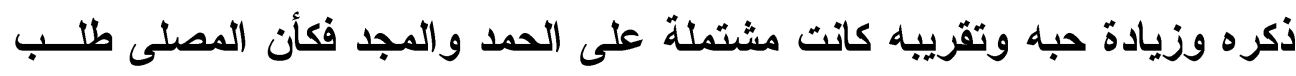

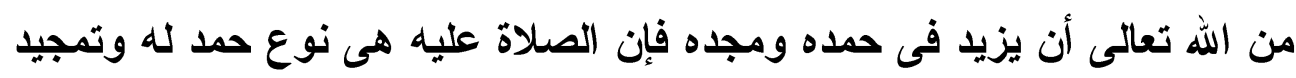

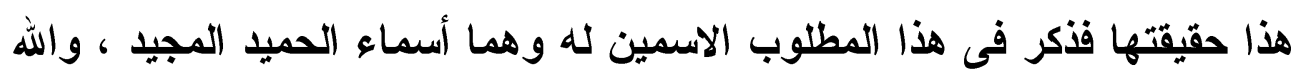

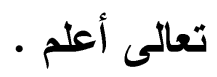

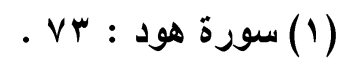

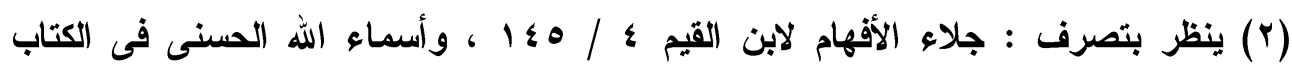

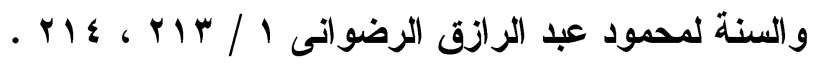




\section{الخاقمة}

الحمد الله الذى بنعمته تتم الصالحات هلى إلى الصواب وأرشد إليــه

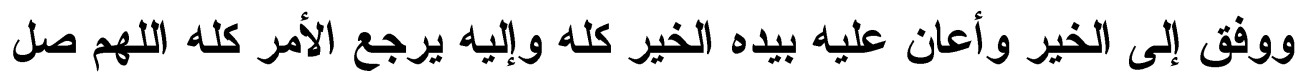

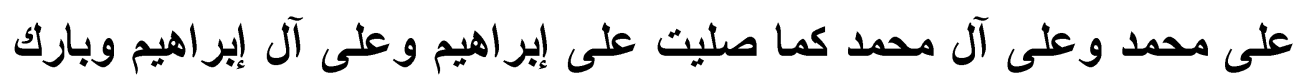

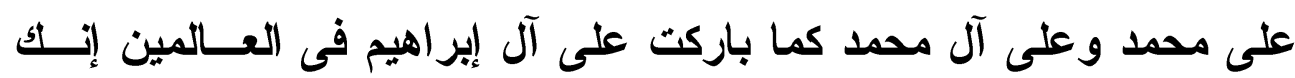

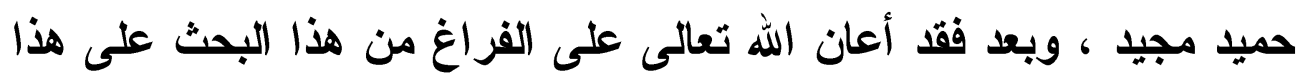

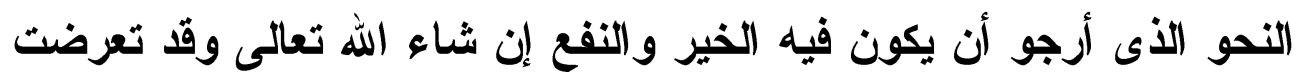

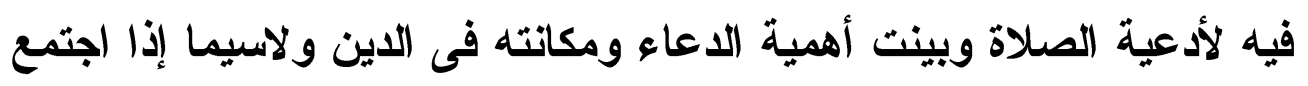

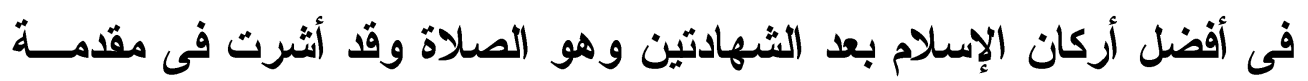

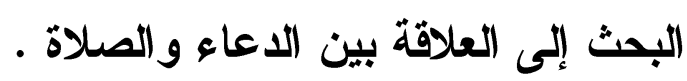

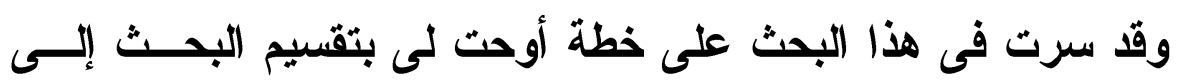

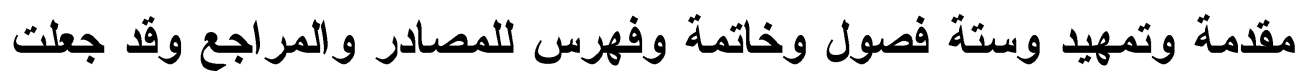

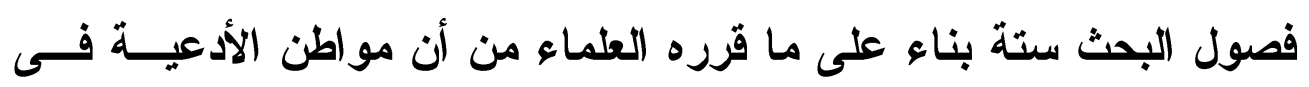

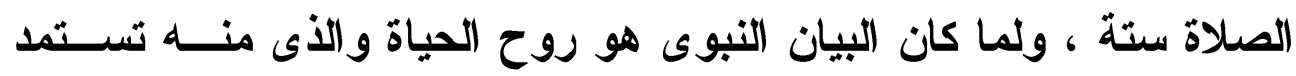

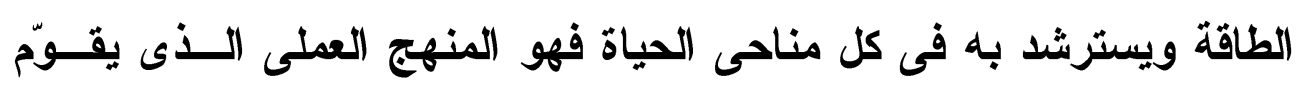

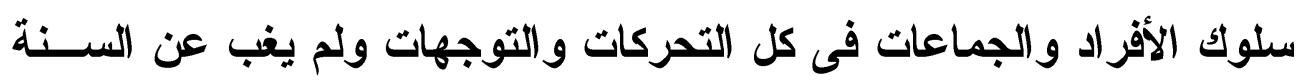

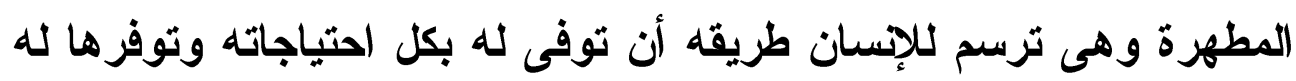

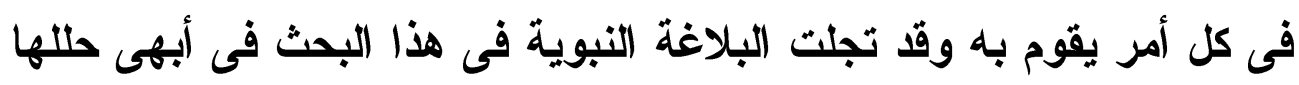

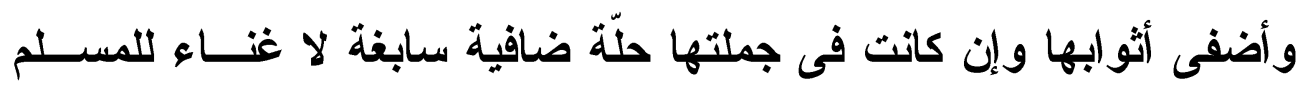

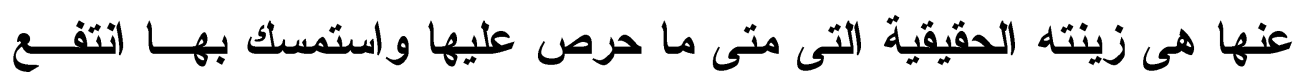

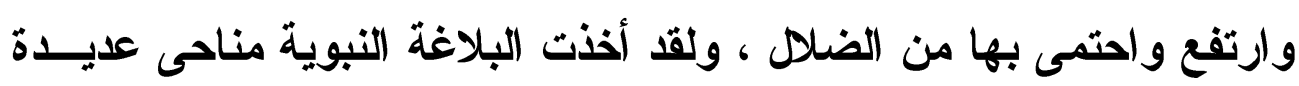

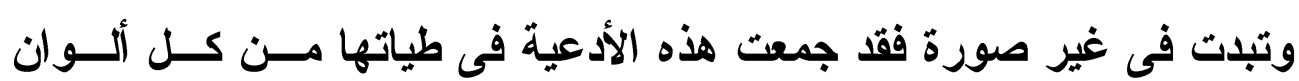

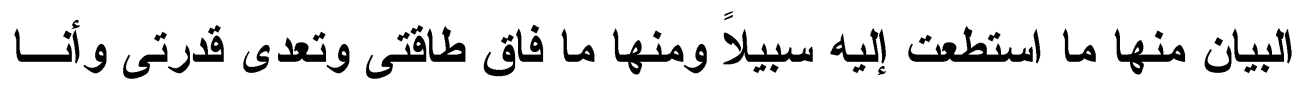

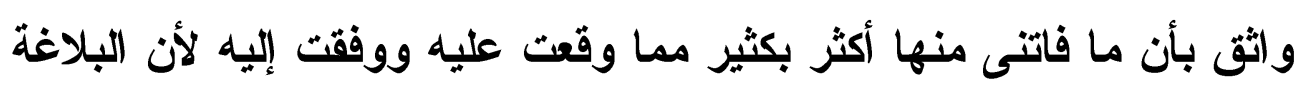


النبوية كما ذكر العلامة الر افعى - رحمه الله - " هى البلاغة التى ســجدت

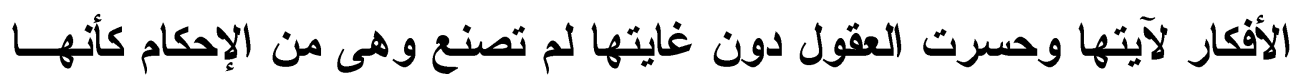

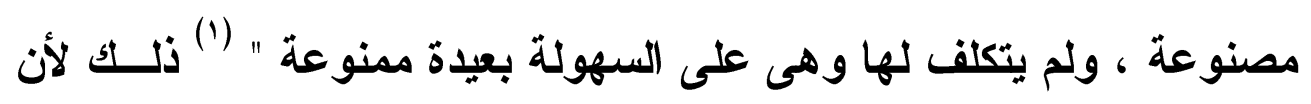
كلامه

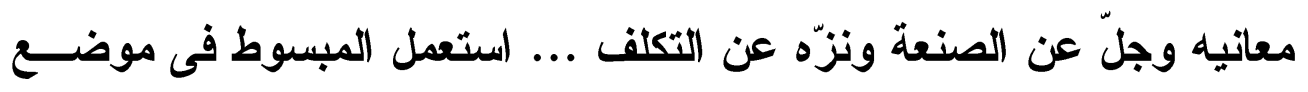

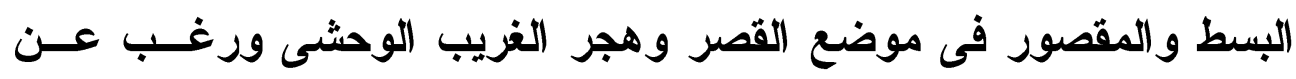

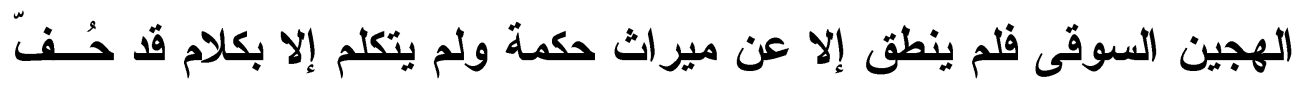

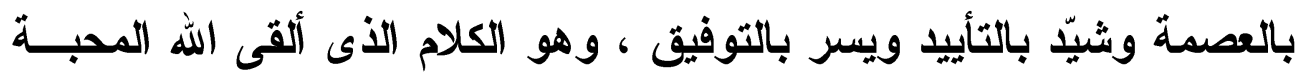

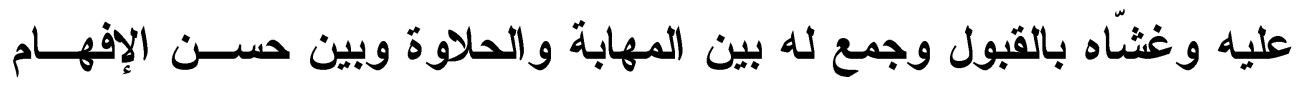

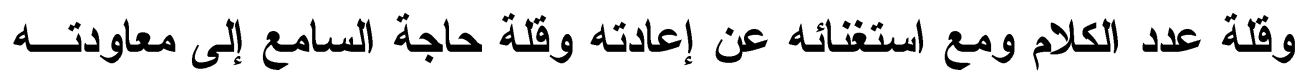

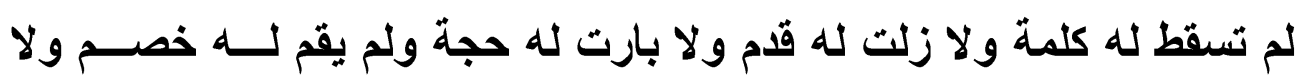

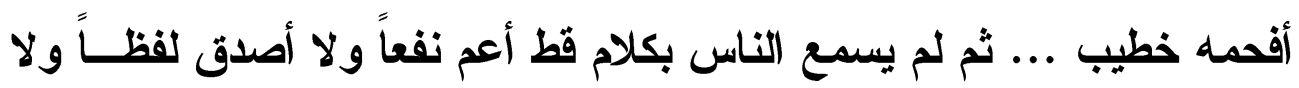

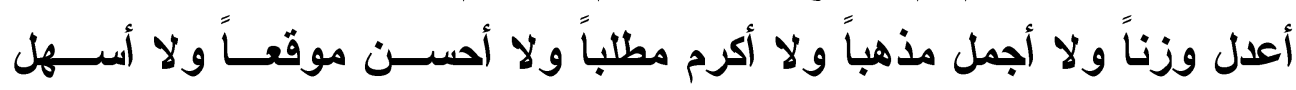

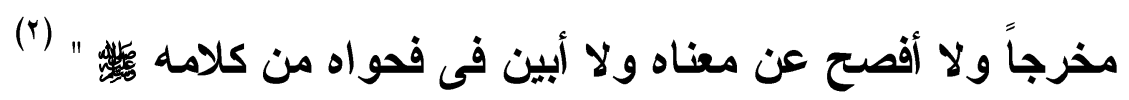
وبلاغته حدها فلا أستطيع ولا أحد من الناس " ولو حك بيافوخه السماء " كما كــان

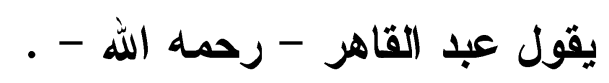
هذا .. وكنت قد استخلصت عدة أمور من هذه الدراسة هي كالن النتائج أود أن أثنير إليها وهى :

(1) تاريخ آداب العرب للرافعى r / rV9 ، طبعة دار الكتاب العربى ، بيروت ، لبنان ، طبعة

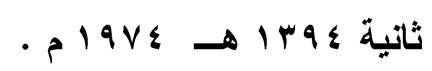

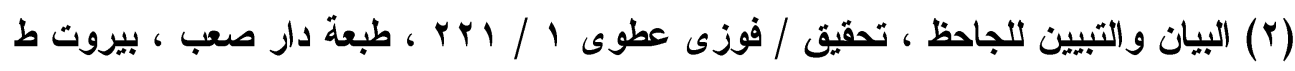

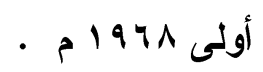




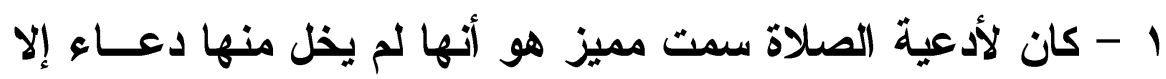

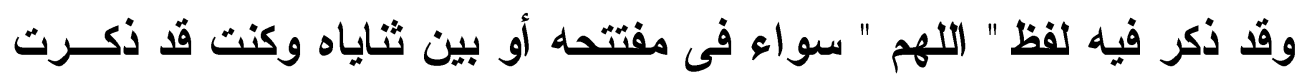

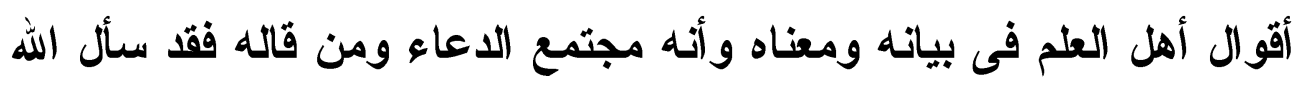

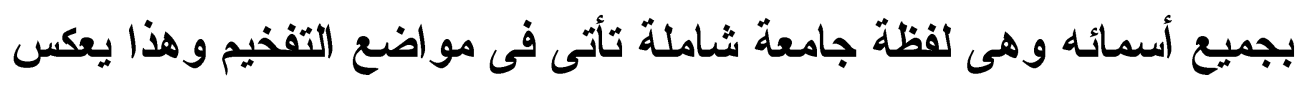

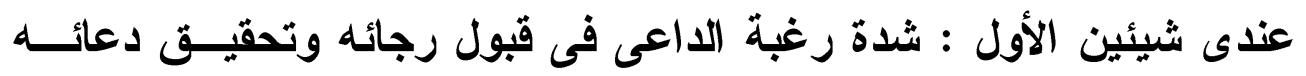

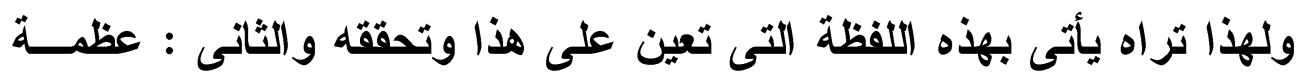

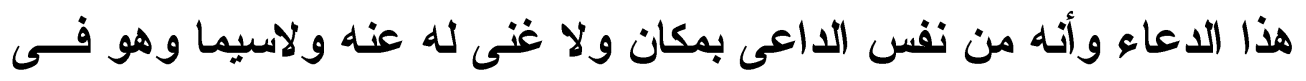

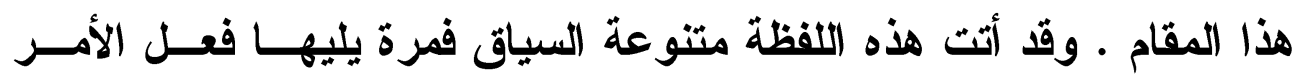

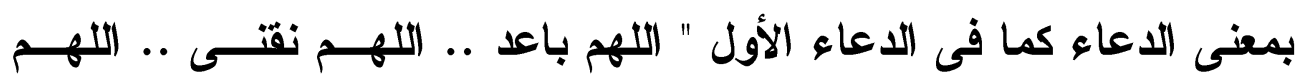

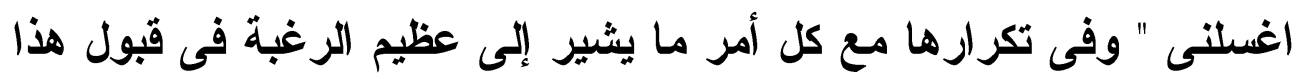

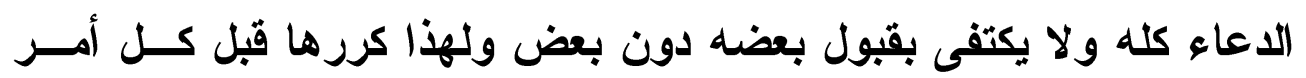

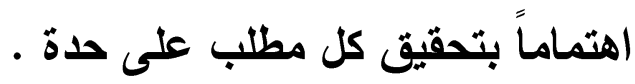

وفى الاعاء الثانى " ... اللهم اغفر لى " وفى الدعاء الخامس " اللهم اغفر لى وارحمنى وعافنى واهدنى وارزقنى " وكأن طلب المغفرة وما تلاها

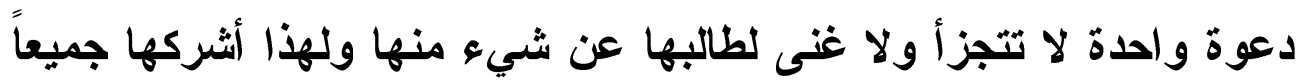

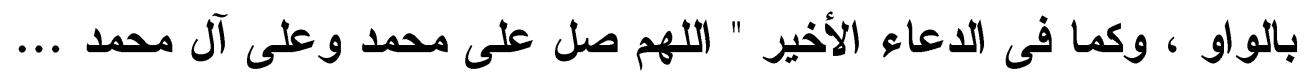

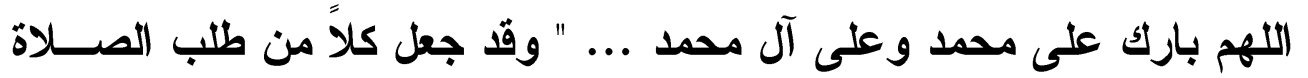

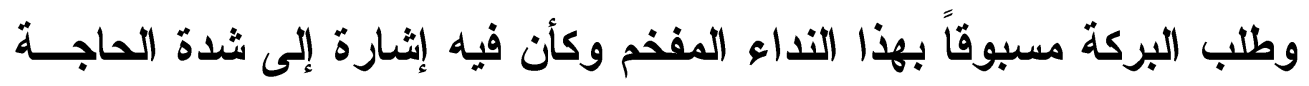
وفيه ما يطمئن الداعى وكأنه يرى فيه ملامح القبول ومخايل الاستجابة وفيه

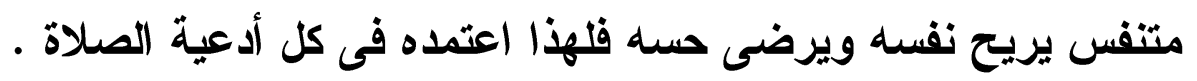

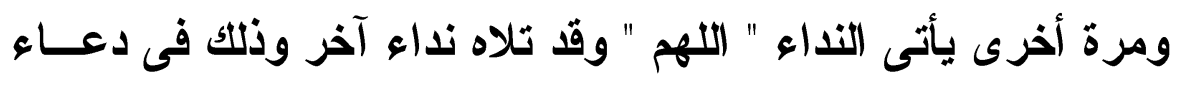

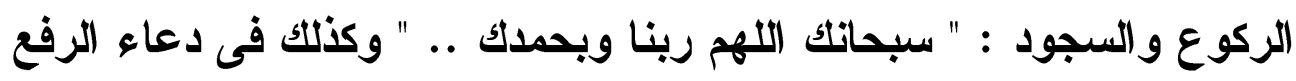

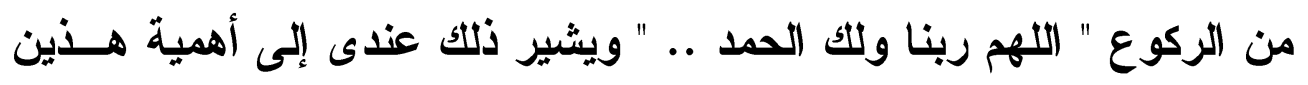


الركنين فى الصلاة حتى كأن الصلاة إنما هى ركوع وسجود ، ولأن النــــاء

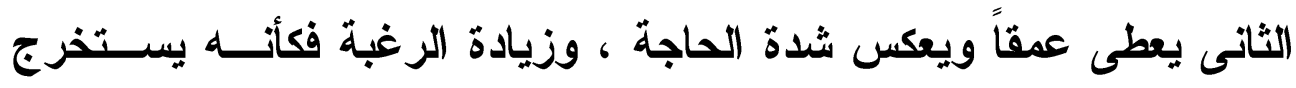

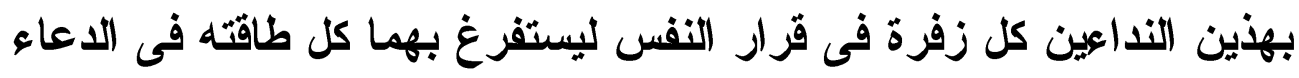

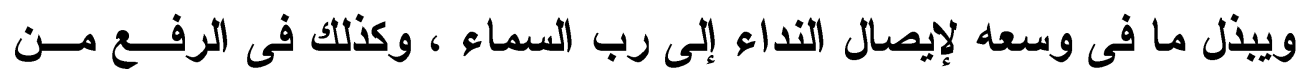

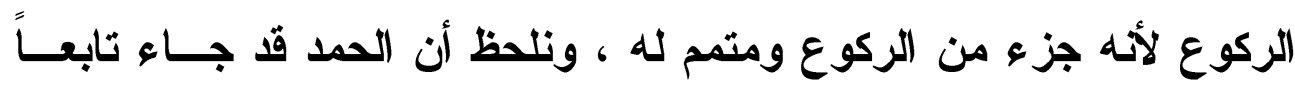

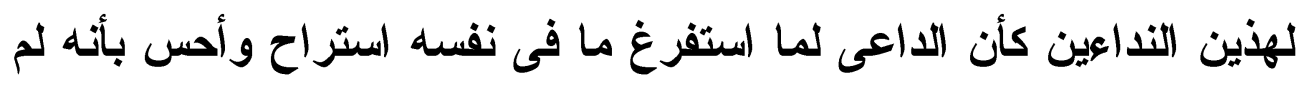

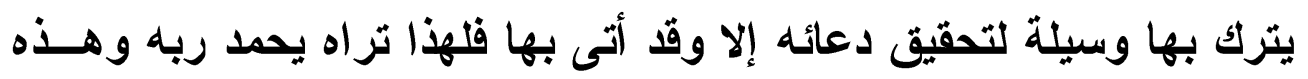

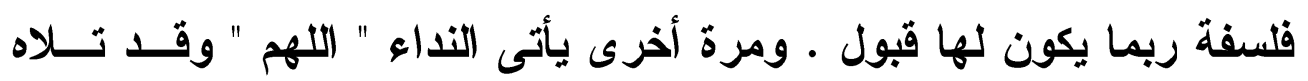

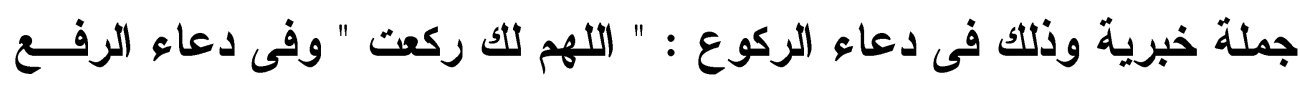

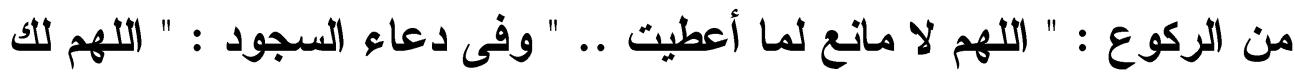

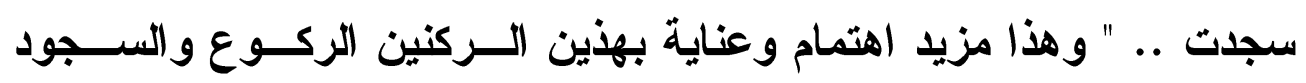

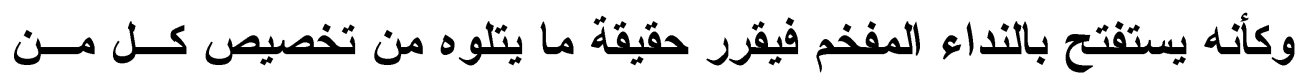

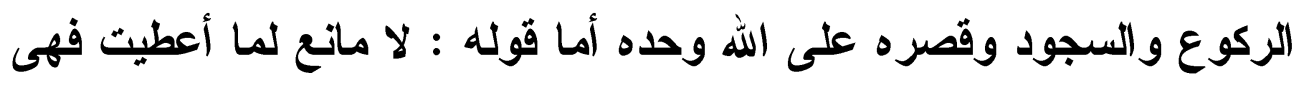

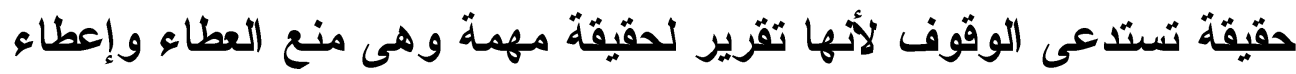

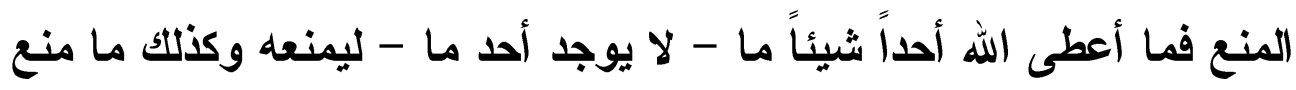

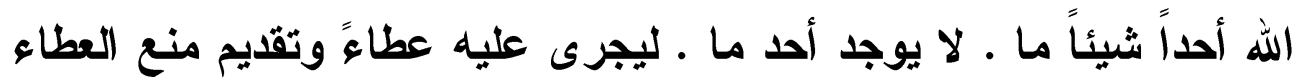

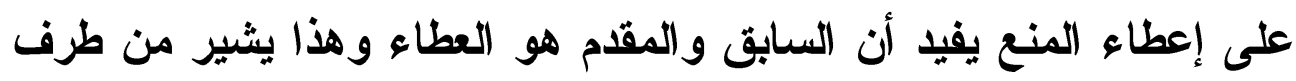
خفى إلى صفة الرحمة وسبقها وغلبتها فالعطاء من الله مأمول وهو مظهـئر

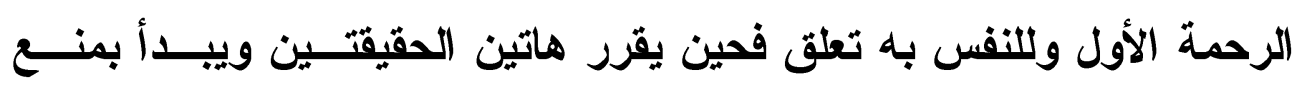

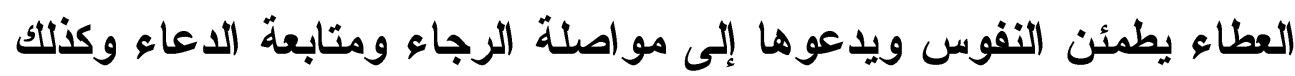

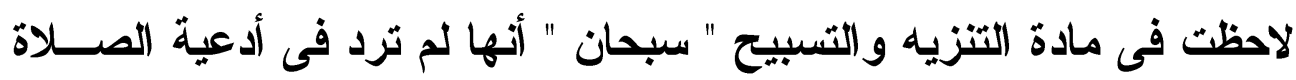

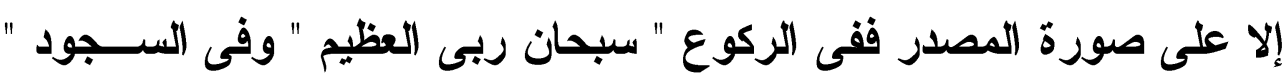

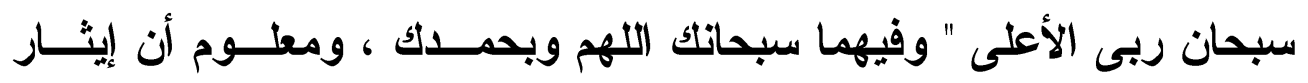


التعبير بالمصدر بلل الفعل يفيد المبالغة وهذا يال علــى ثبـوت التســبيح

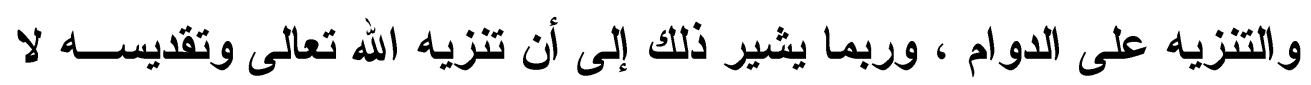

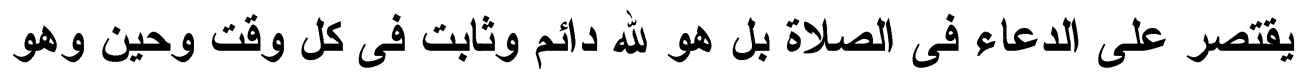

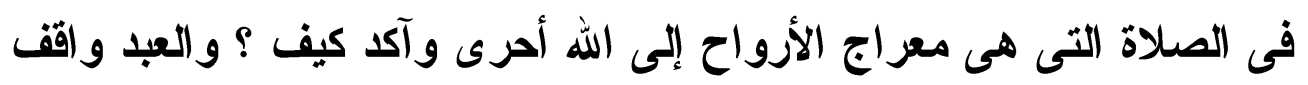

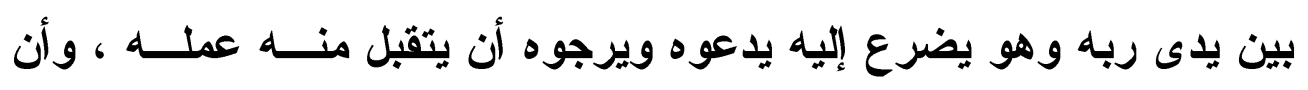

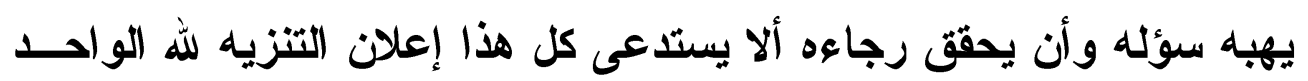

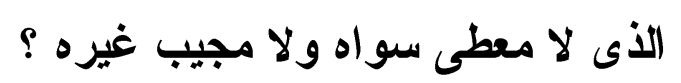

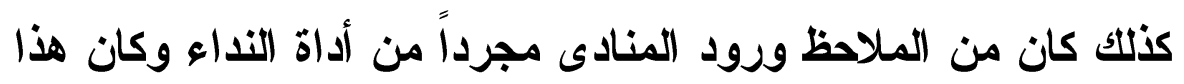

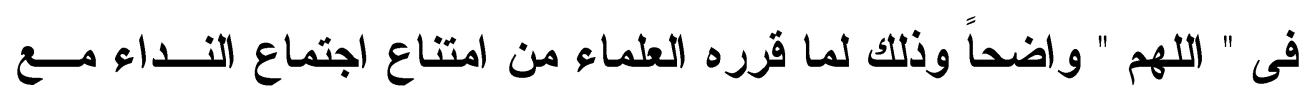

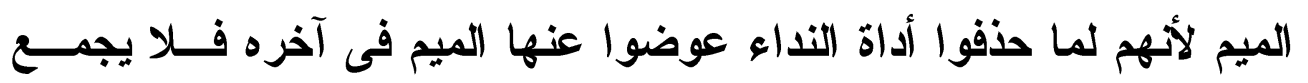

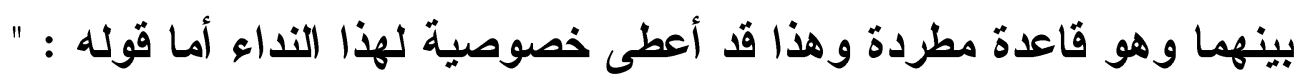

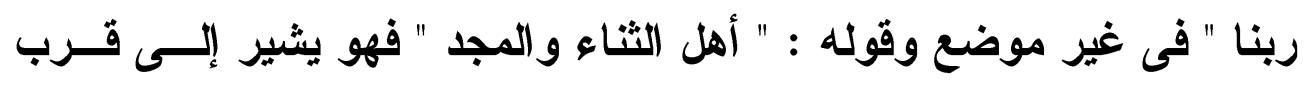

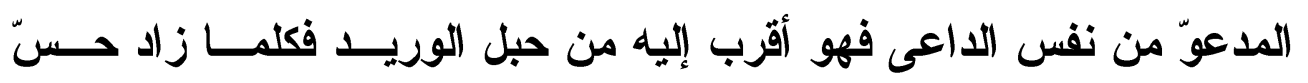

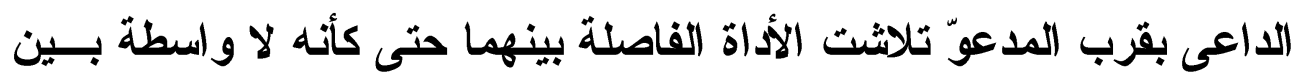

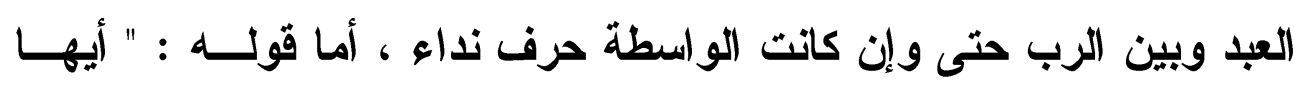

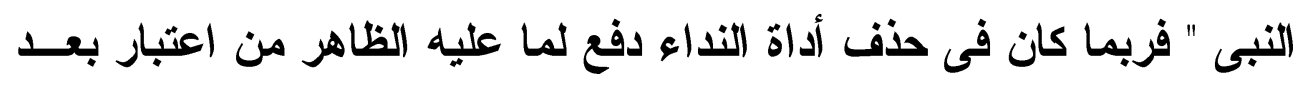

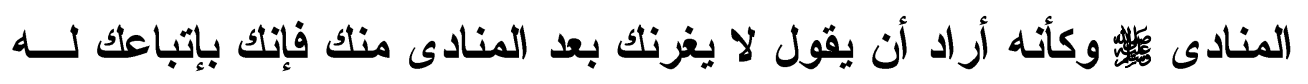
و اقتدائك به وقيامك على سنته وسيرك على طريقته كأنه يقدمك وأنت تتبعه

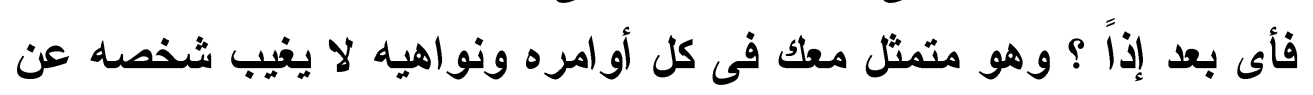

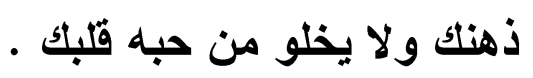

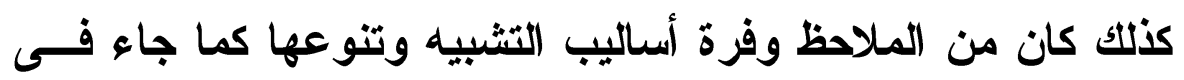

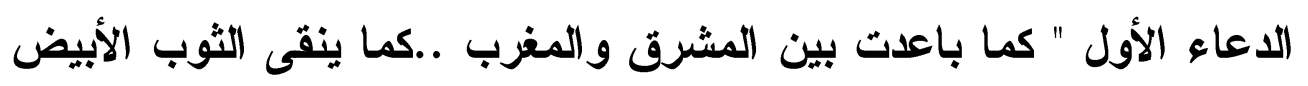
من الانس " وفى التثبيه بالمحسوس كما قال العلماء تقريب للمعانى وإدناء لاءول 
لها من الأفهام وكذلك كما قال عبد القاهر " التمثيل بالمشاهدة يزيدك أنساً "

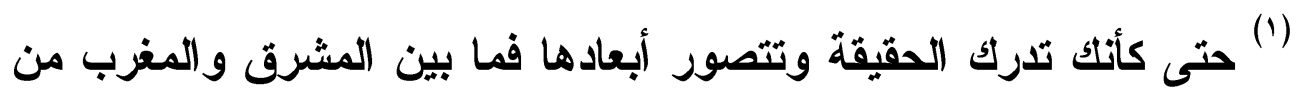

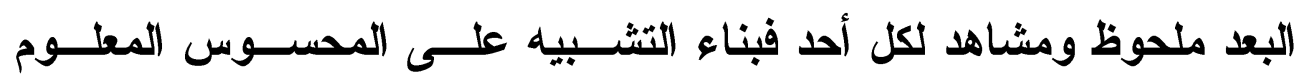

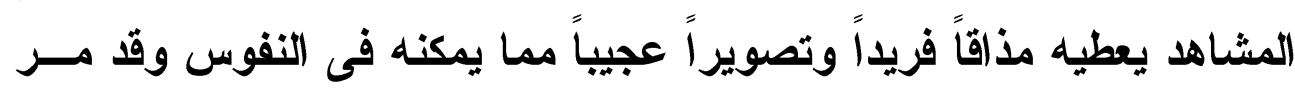

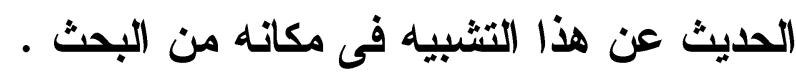

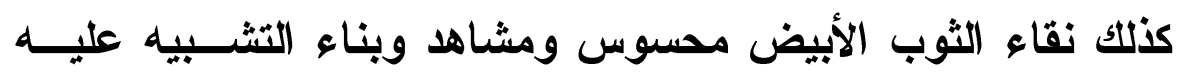

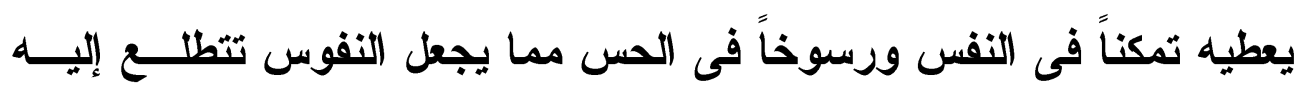

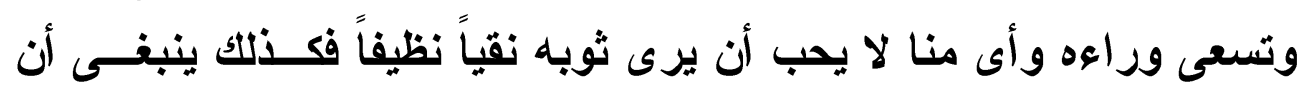
يطلب ذلك لنفسه من الخطايا و الأنوب .

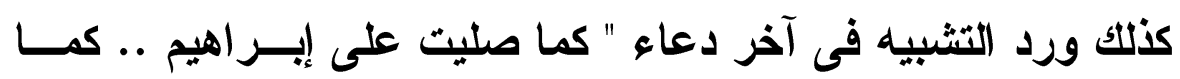

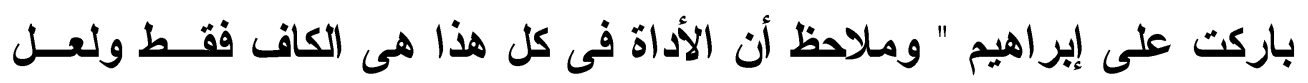

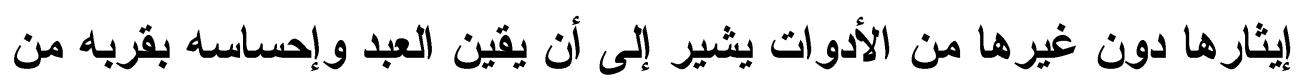

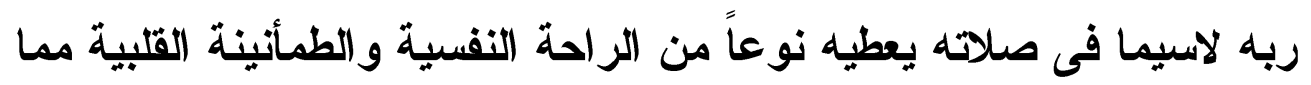

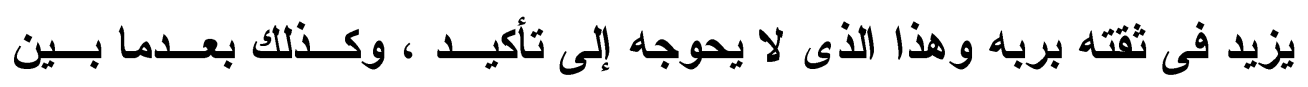

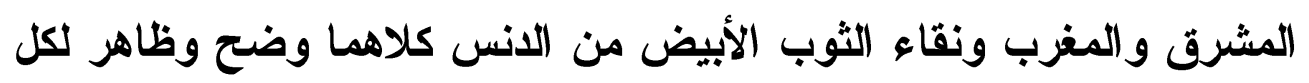

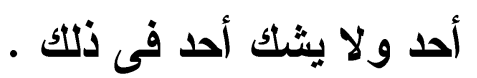

كذلك لاحظت كثرة أساليب القصر ولعلها تبدت في ثوبين فقط هــــا :

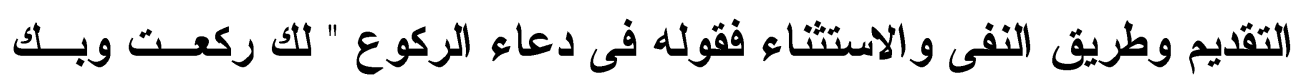

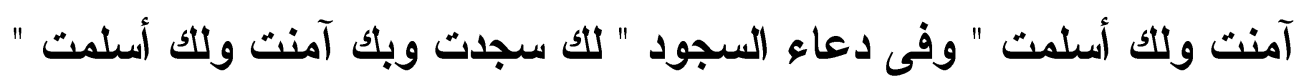

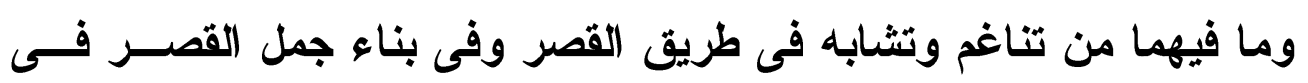

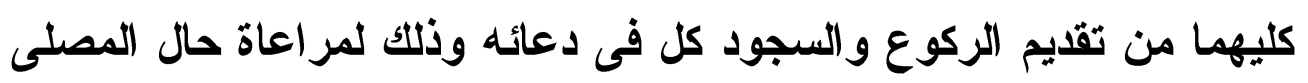

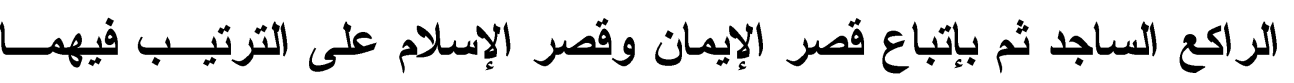


وهذا التشابه يشير إلى التشابه الثديد بين الركنين الركوع والسجود وأنهما

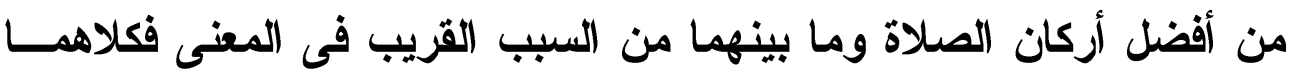

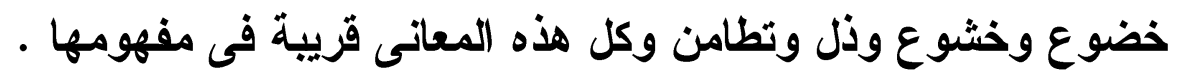

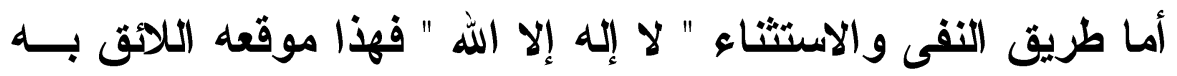

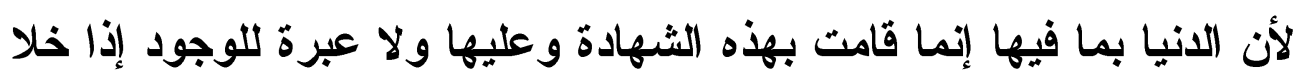

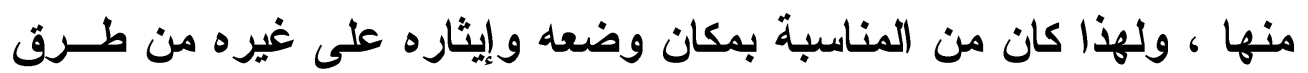

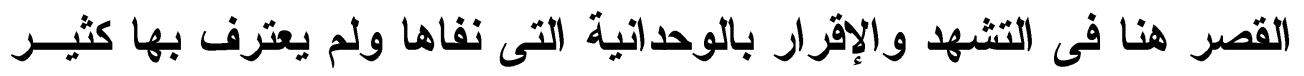

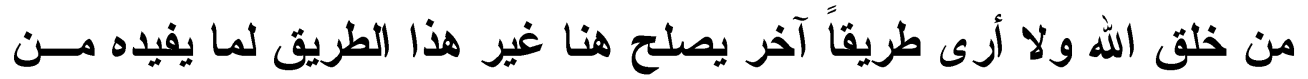
التوكيا والتثديد لأن مقامه مقام إنكار وجحود ورفض ألمات أما عن نسث البلاغة

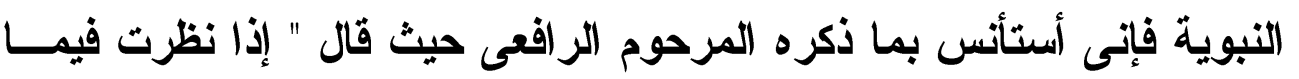

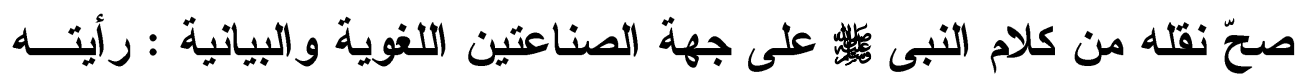
مسدد اللفظ محكم الوضع جزل التركيب متناسب الأجزاء فى تأليف الكلمــات

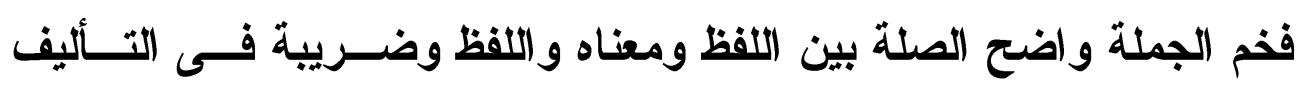

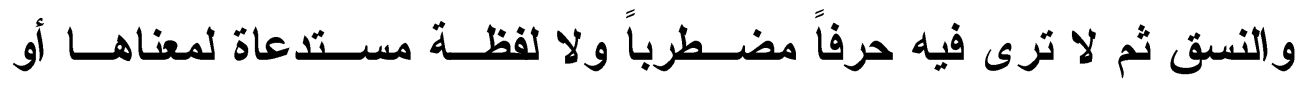

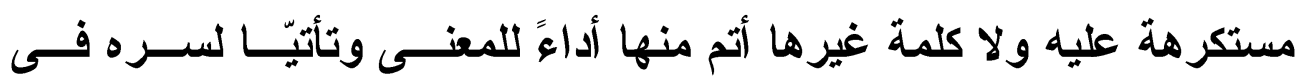

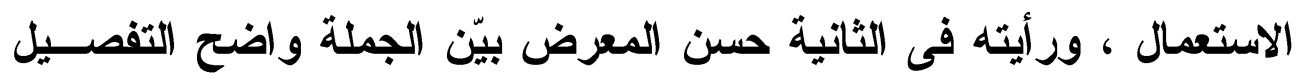

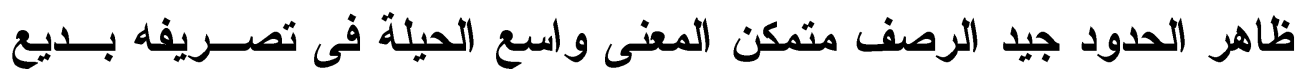

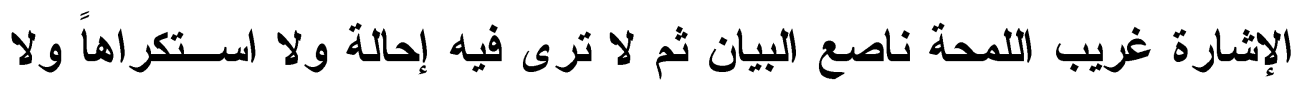

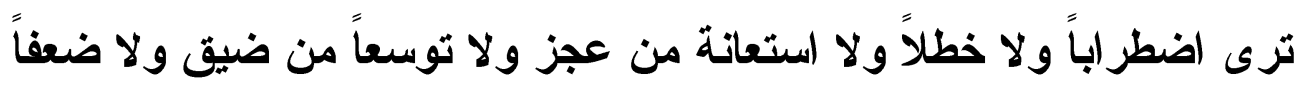
فى وجه من الوجوه " (')

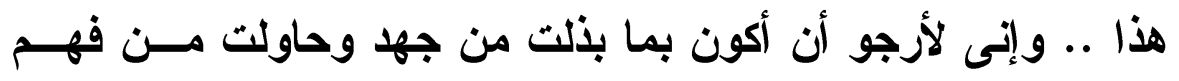
وسعيث إلى استنباط نحو محاولة للوقوف على جوانب البلاغة النبوية فـى النى 
أدعية الصلاة - قد بلغت ما أردت حين نصبت نفسى لهذا العمل حرصاً على الهي

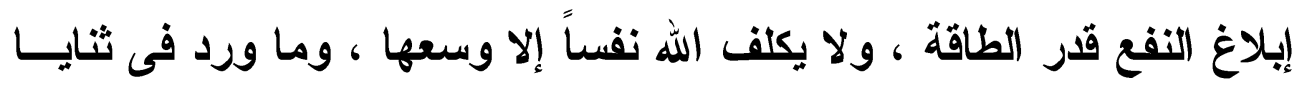

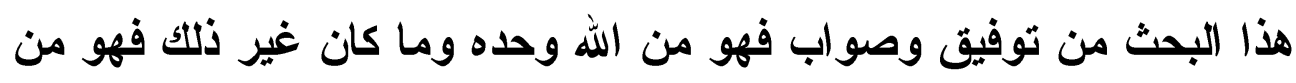

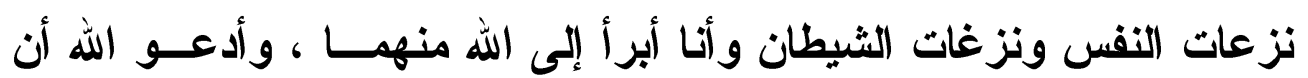

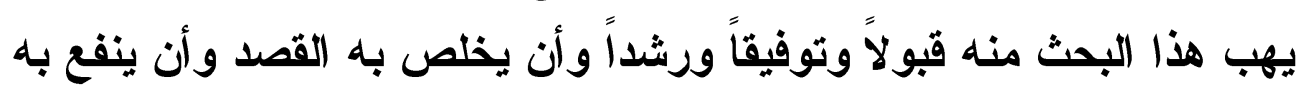

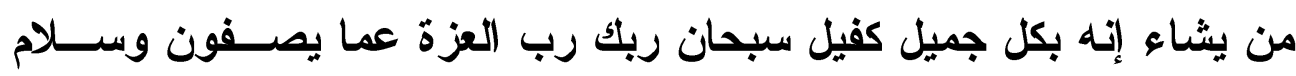

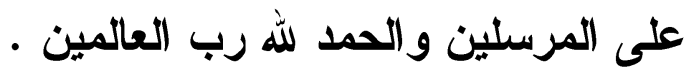

\section{وكتبه}

على بن محمد بن عبد الرحيم بن محمد

غفر الله له ولو الديه وللمسلمين أجمعين عبد الرحيم بن بحمي 


\section{ثبت المسادر والمراجع}

1 - الإققان فى علوم القرآن للسيوطى ، تحقيق / محمد أبو الفضل إبراهيم

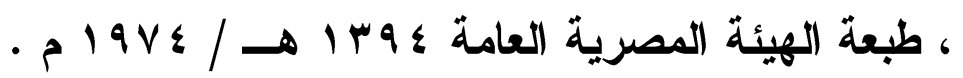

r - إحكام الأحكام شرح عمدة الأحكام لابن دقيق العيد .

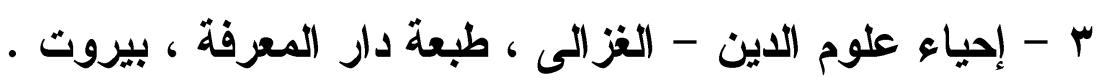
ع - الأدب المفرد للبخارى ، تحقيق / محمد فؤاد عبد الباقى ، طبعــة دار

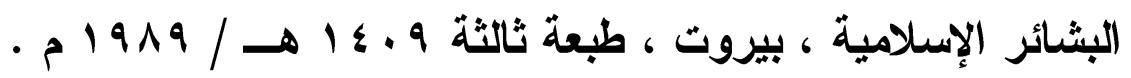
ه - أسساس البلاغة للزمخشرى ، تقديم د / محمود فهمى حجازى ، طبعـة

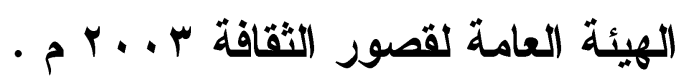
4 - أسرار البلاغة عبد القاهر الجرجانى ، تعليق / محمود شاكر ، طبعـة

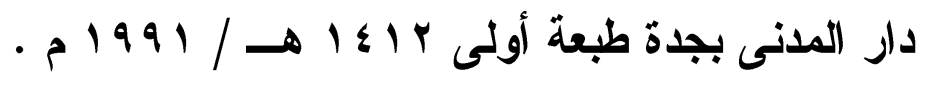

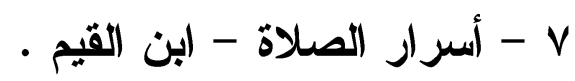

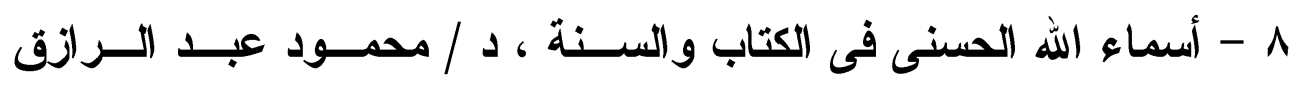

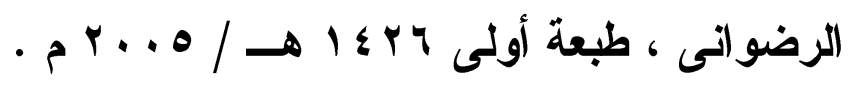

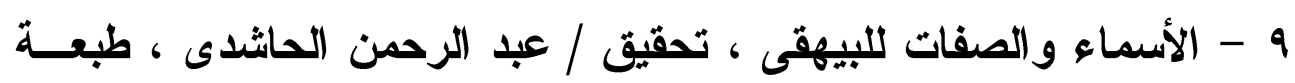
مكتبة السوادى بجدة ، طبعة أولى • الأل

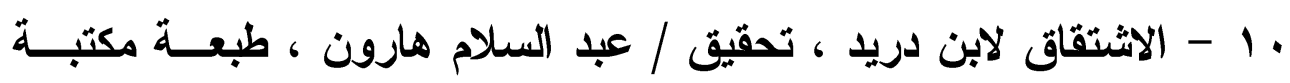
الخاتجى مصر طبعة ثالثة . الانئ 11

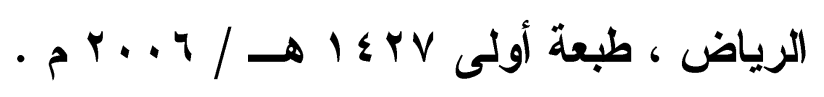

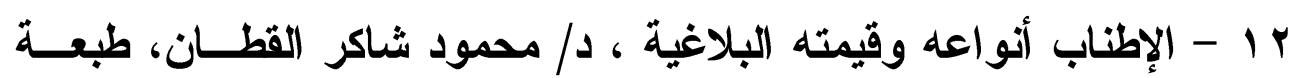

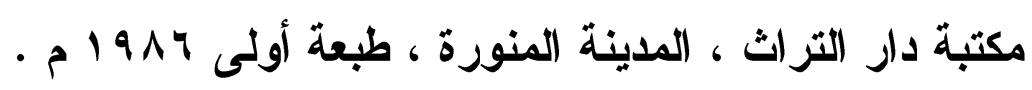

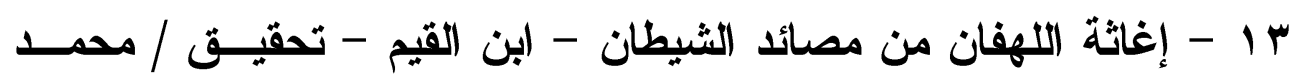

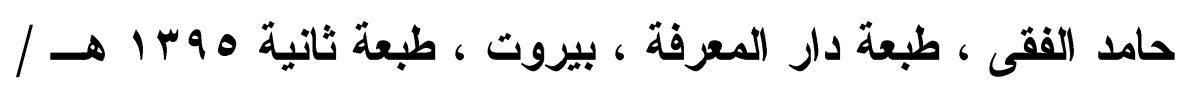




$$
\text { - } 19 \vee 0
$$

ع 1 - اقتضاء الصر اط المستقيم مخالقة أصحاب الجحـيم ، (بــن تيميــة ، تحقيق / محمد حامد الفقى ، طبعة مطبعة السنة المحمدية القاهرة ،

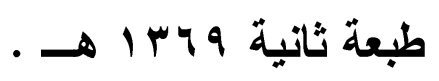

10 17 - دمشق

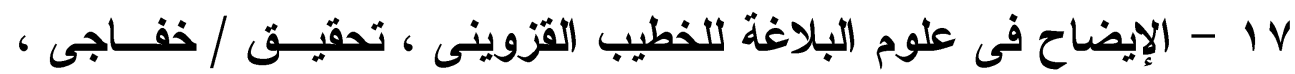
طبعة دار الجيل بيروت ، و طبعة دار إحياء العلوم ، بيروت ، طبعة

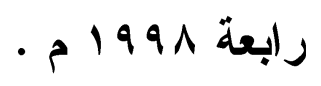

1 1 - بدائع الفوائد لابن القيم ، طبعة دار الكتاب العرب ، بيزوت ، لبنان.

$$
19 \text { - البديع فى نقد الشعر لأسامة بن منقة. }
$$

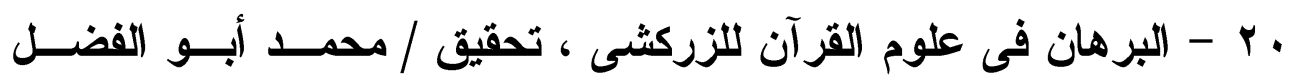

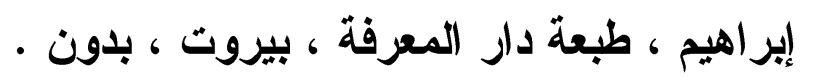

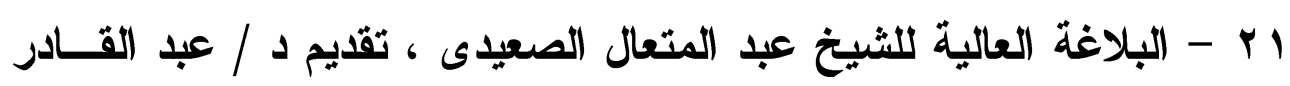

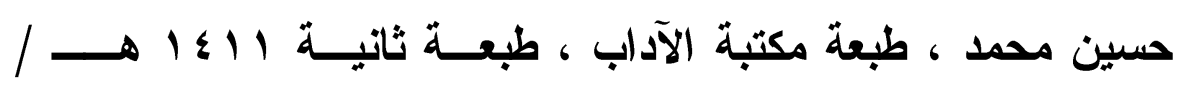

$$
\text { - } 1991
$$

r r - البلاغة العربية أسسها وعلومها وفنونها ، د / عبد الرحمن الميدانى

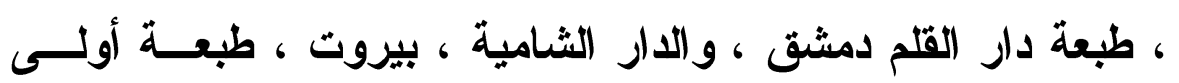

$$
\text { - م) } 997 / \text { ه } 1 \text { \& } 17
$$

rr - بغية الإيضاح للشيخ عبا المتعال الصعيدى ، طبعة مكتبـة الآداب ،

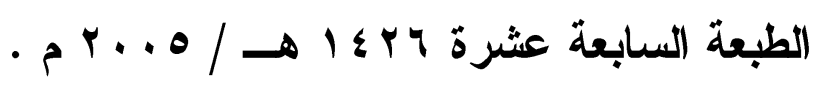

ع r - تاج العروس للزبيدى ، تحقيق / مجموعة من المؤلفين ، طبعــة دار 


$$
\text { الههداية . }
$$

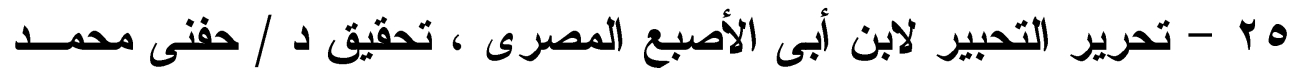

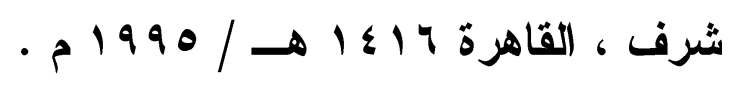

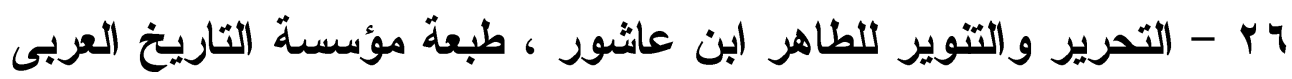

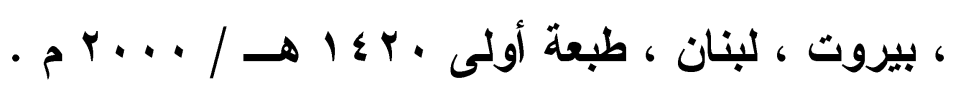

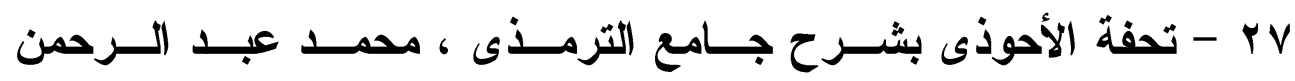
المباركفورى ، طبعة دار الكتب العلمية ، بيروت .

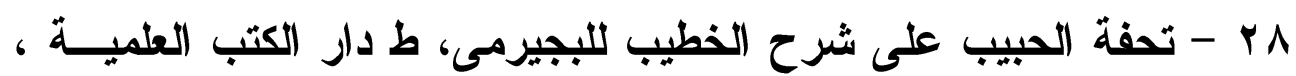

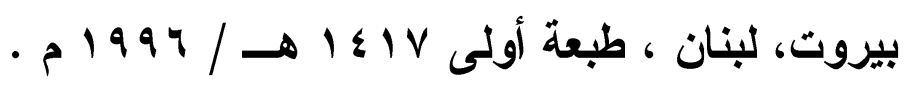

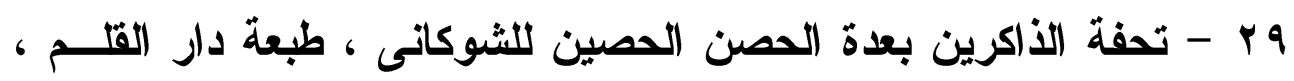

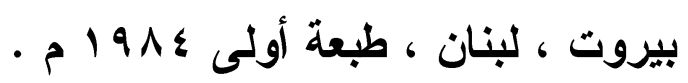

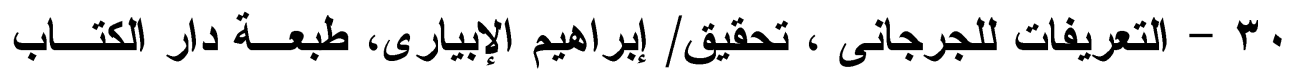

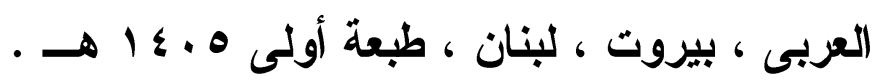

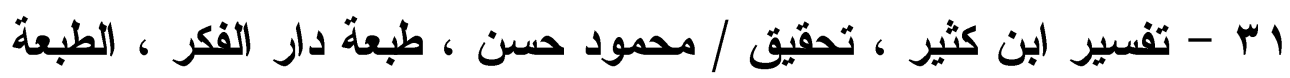

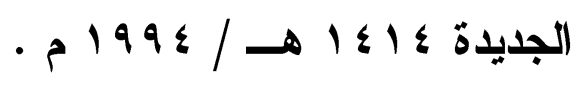

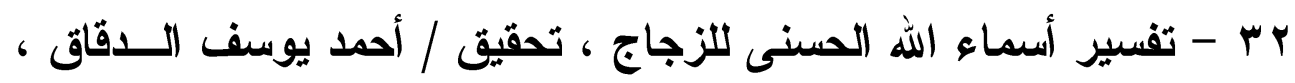

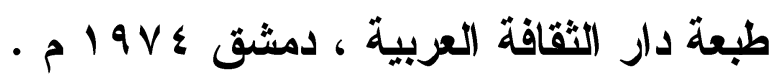

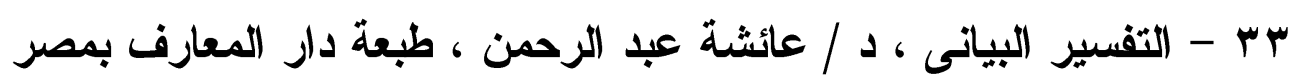

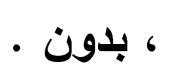

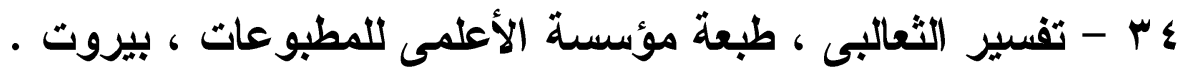

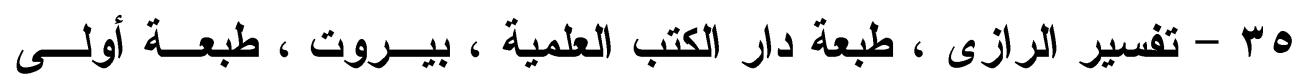

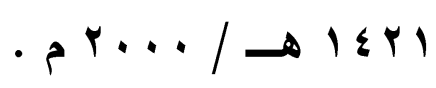

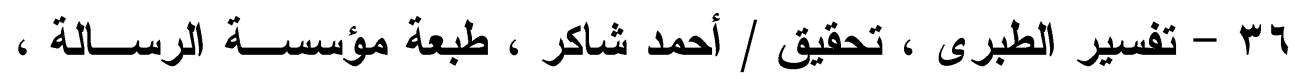

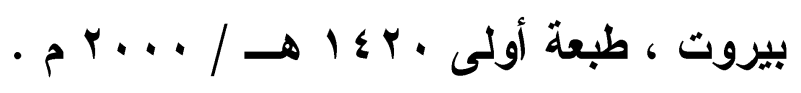


rV - تفسير القرطبى ، طبعة دار إحياء التراث العربى ، بيـروت ، لبنـــان

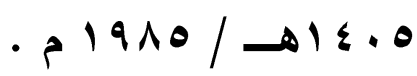

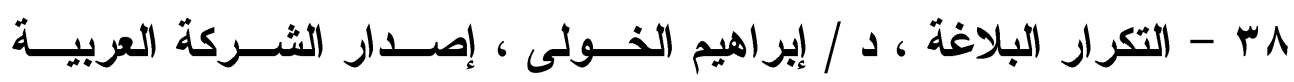

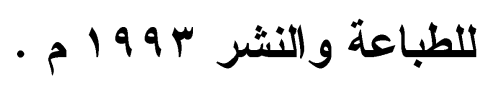

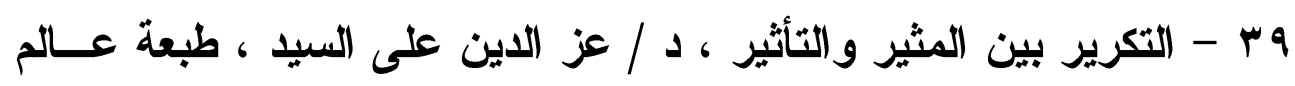

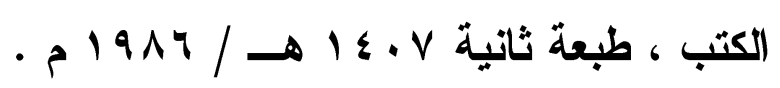

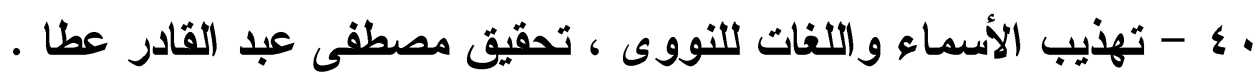

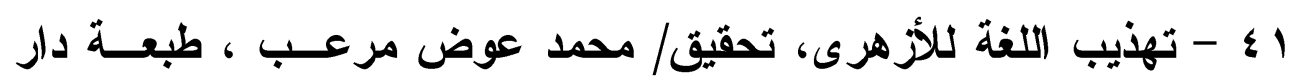

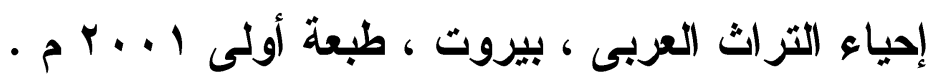

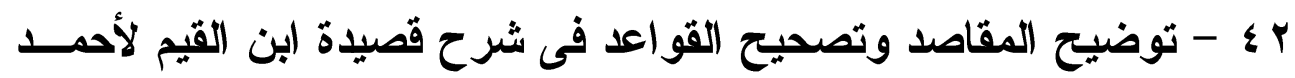

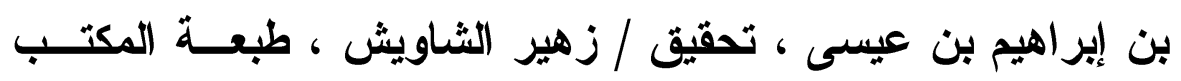

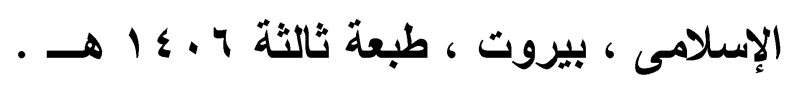

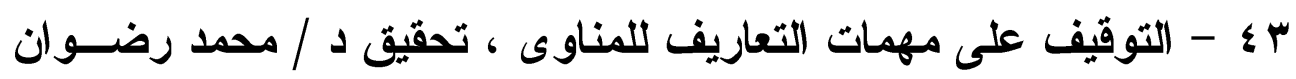

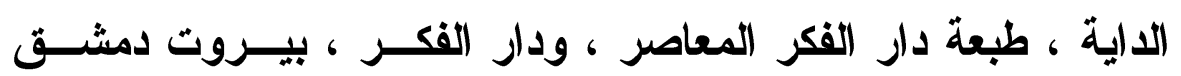

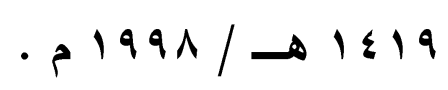

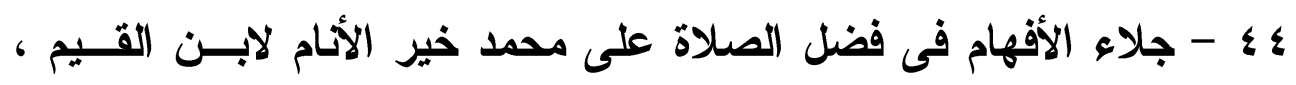

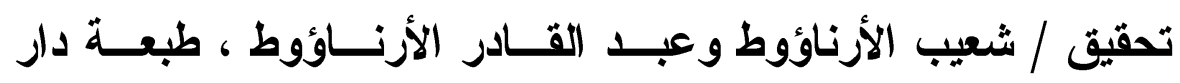

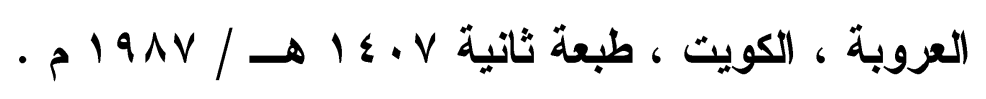

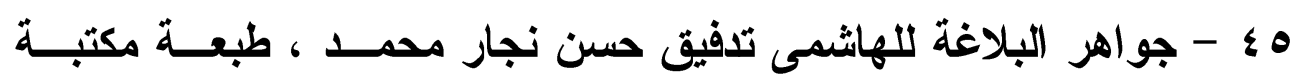

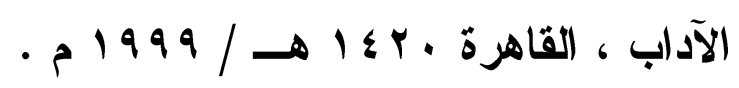

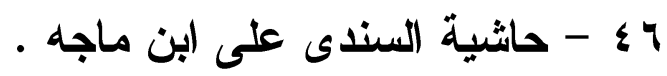

SV

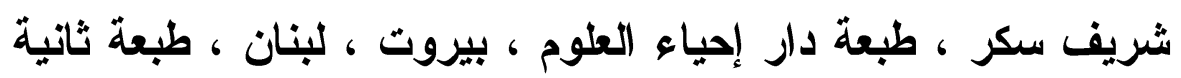

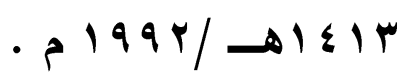




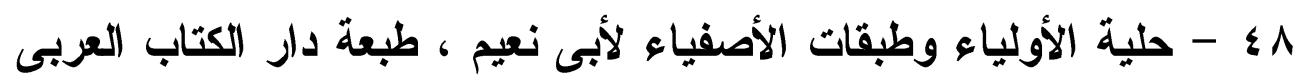

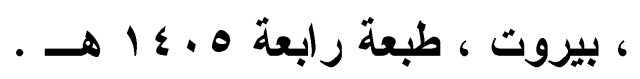

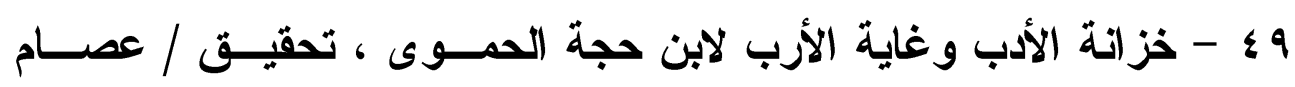

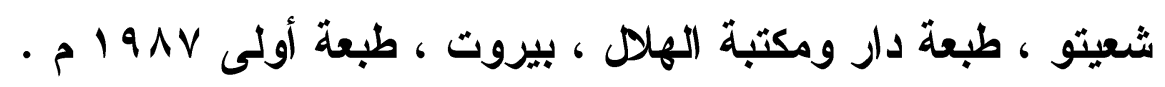

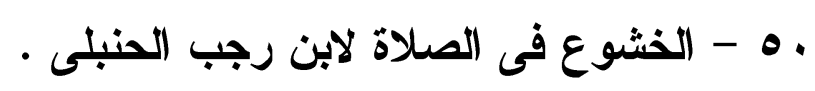

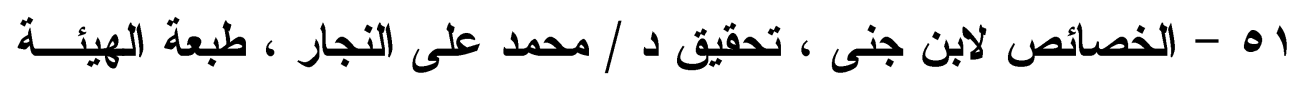

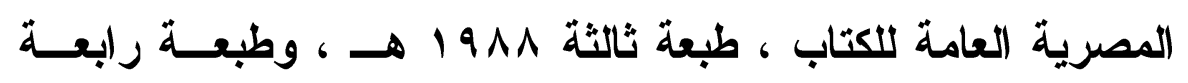
- 1999

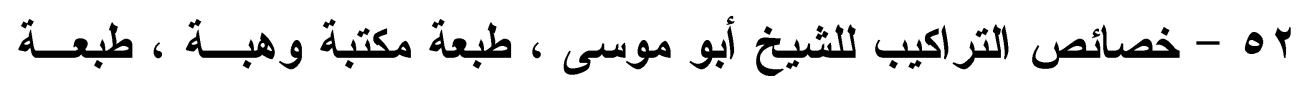

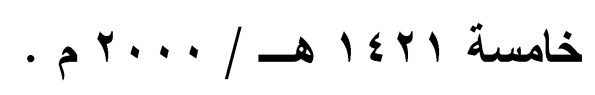

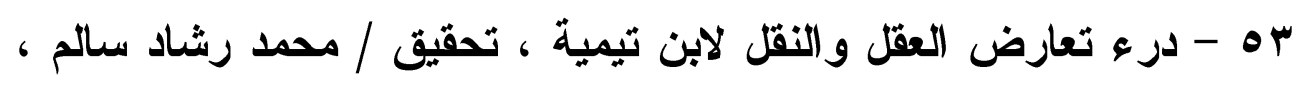

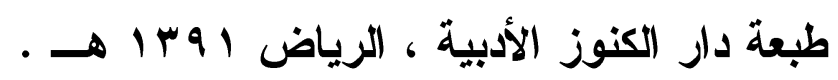

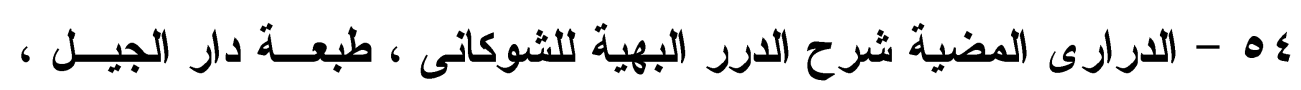

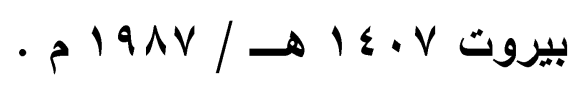

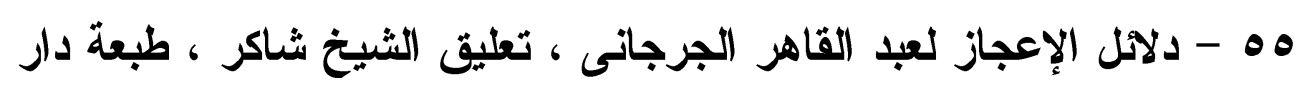

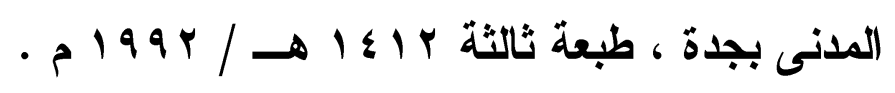

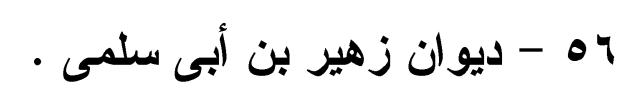

oV

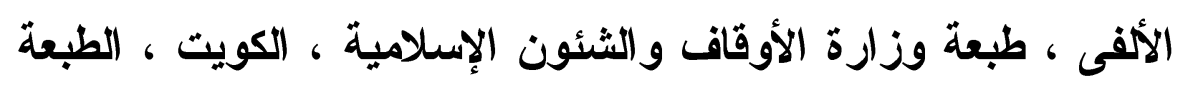

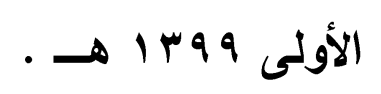

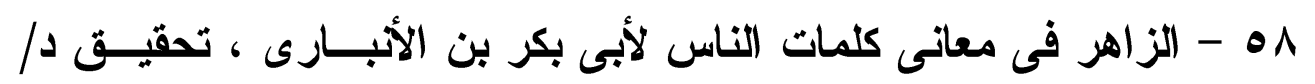

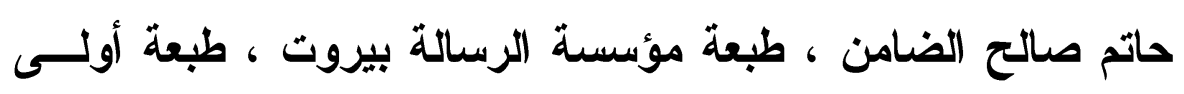

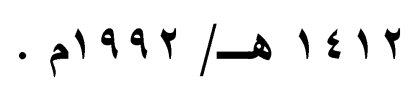




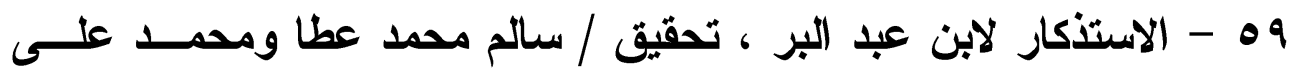

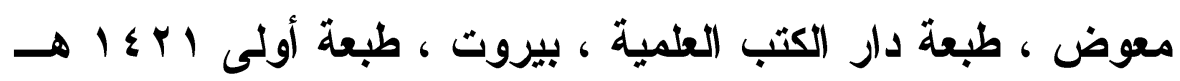

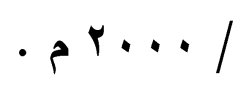

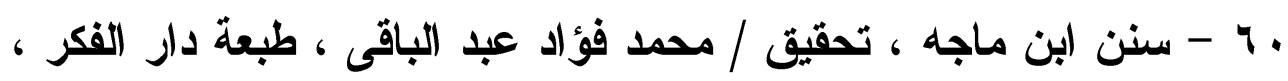

$$
\text { بيزوت }
$$

اף - سنن أبى داود ، تحقيق / محمد محى الدين عبد الحميد ، طبعـة دار

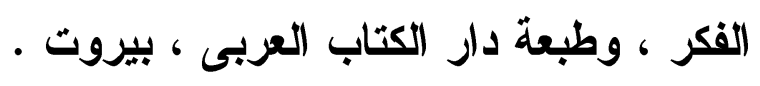

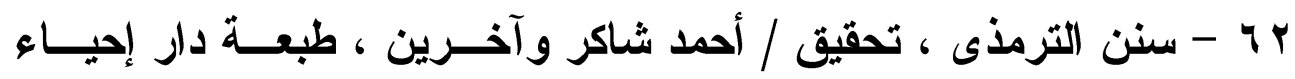

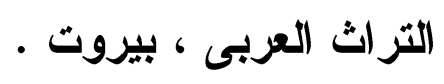

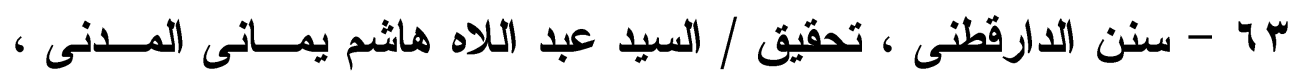

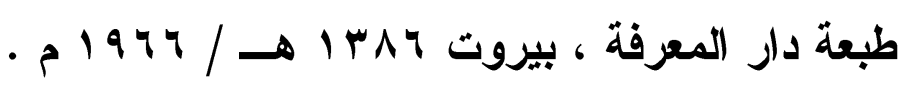

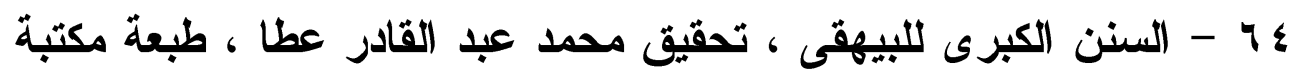

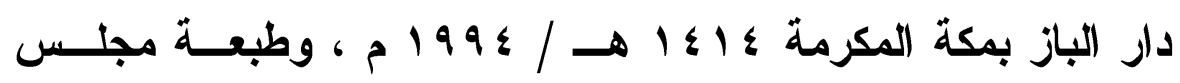

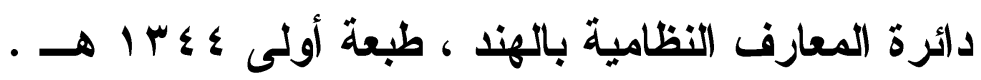

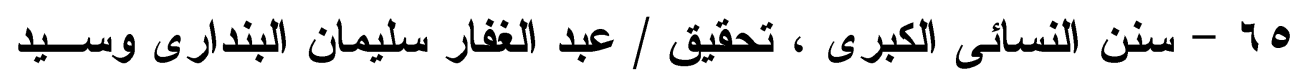

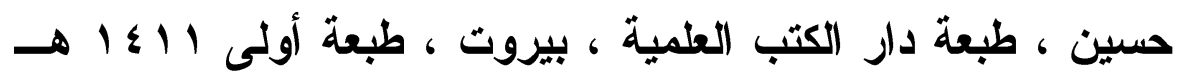

$$
\text { - 1991/ }
$$

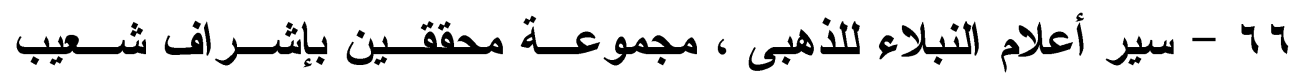

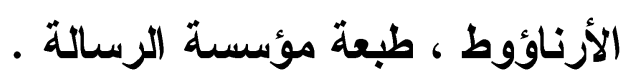

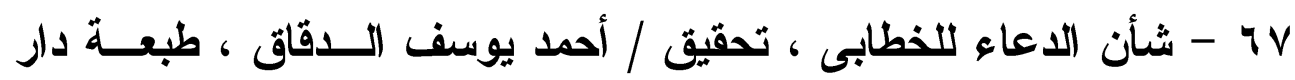

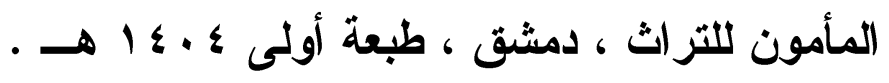

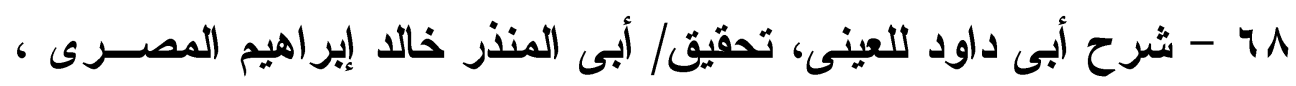

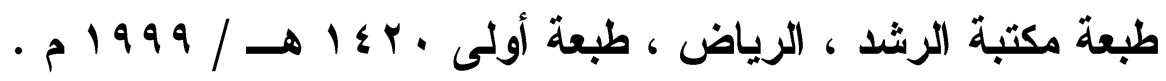


99

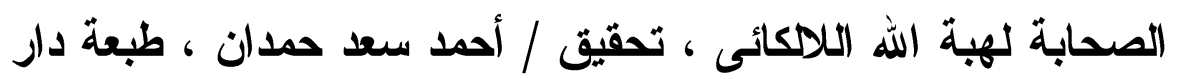

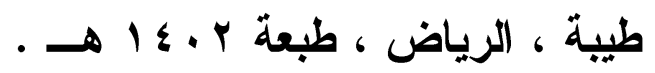

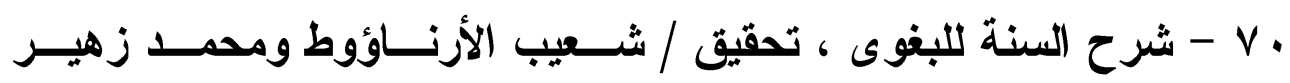

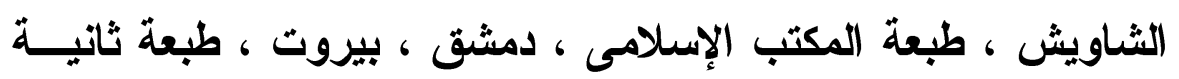

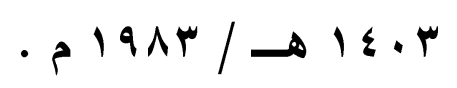

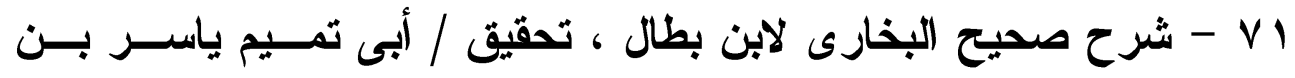

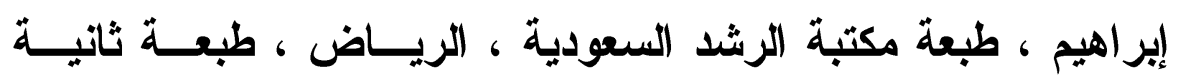

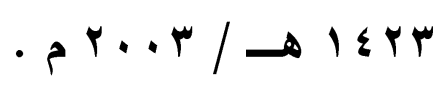

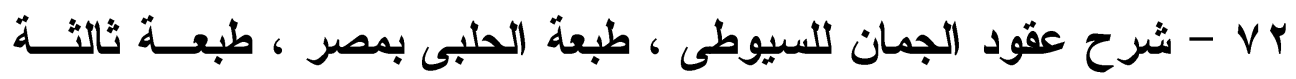

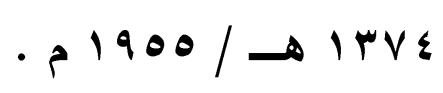

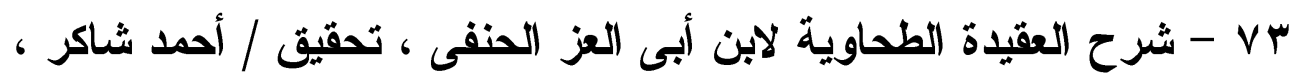

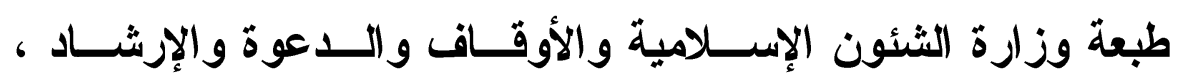

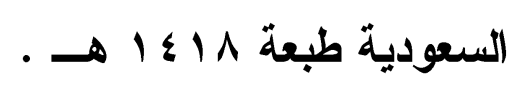

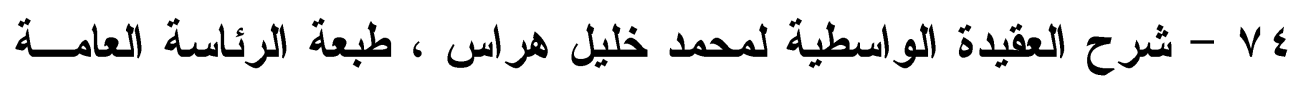

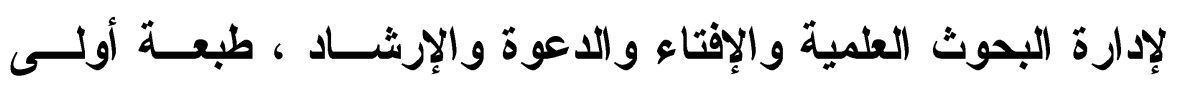

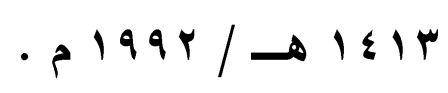

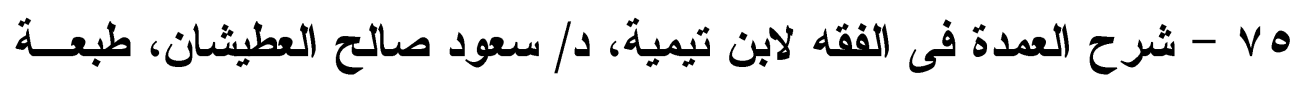

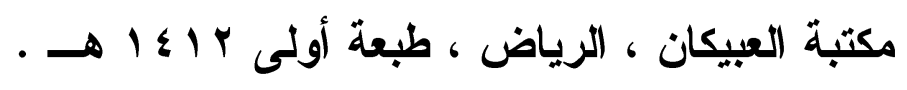

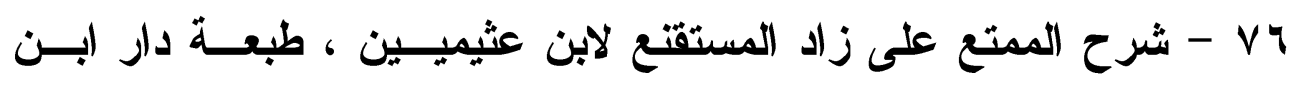

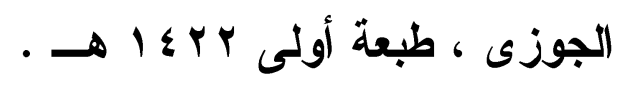

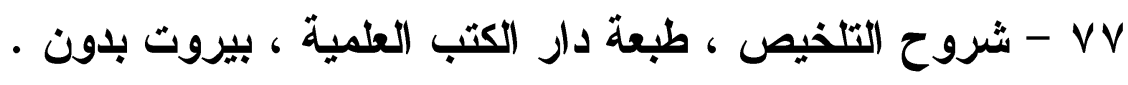
- VA 


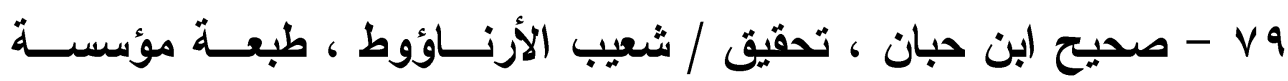

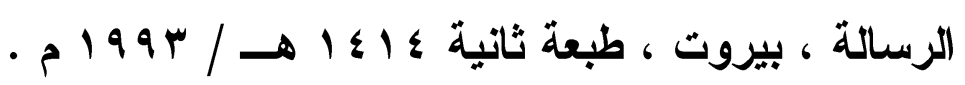

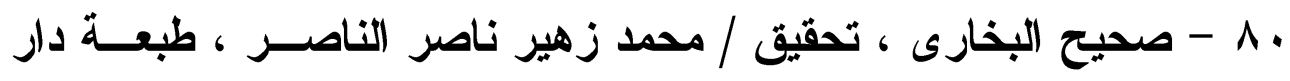

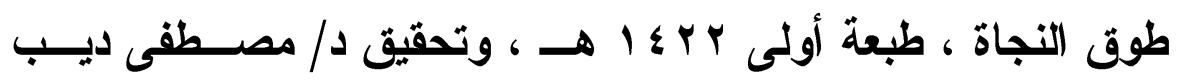

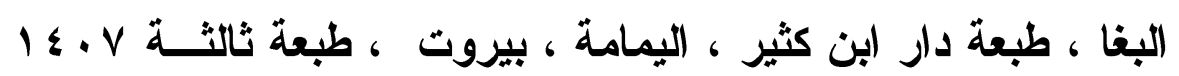

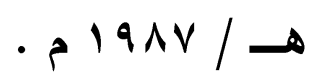

1 - صحيح الترغيب و الترهيب للألبانى، طبعة مكتبة المعارف ، الرياض

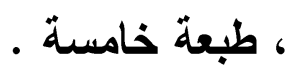

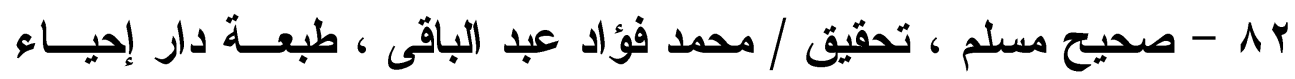

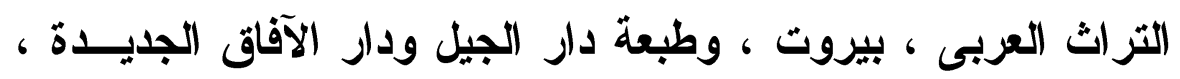

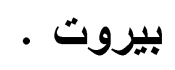

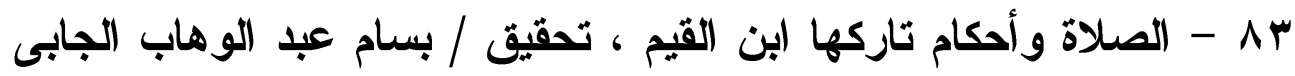

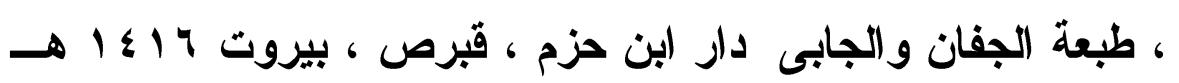

$$
\text { - 1999/ }
$$

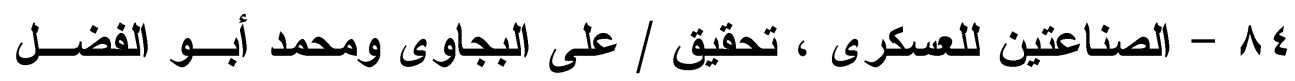

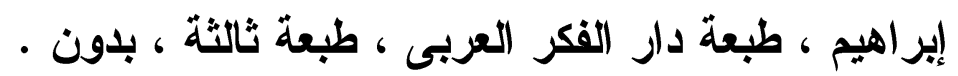

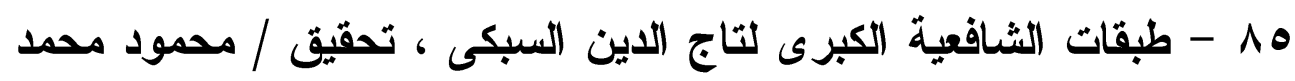

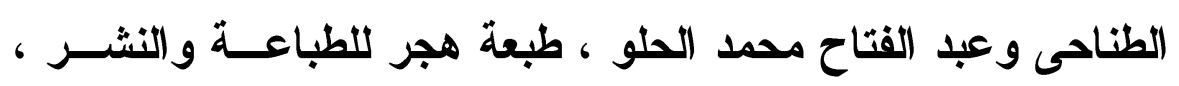

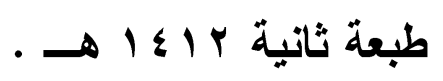

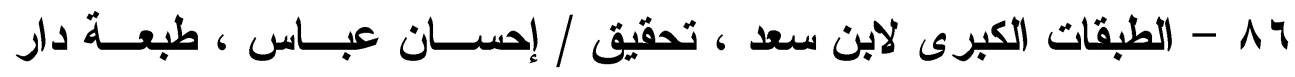

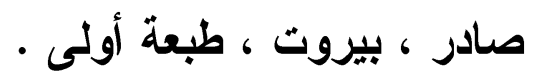

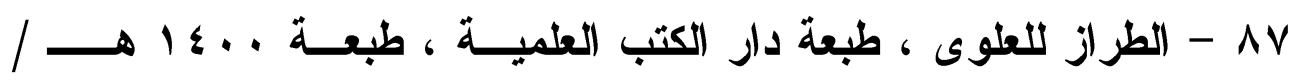
- 191. 


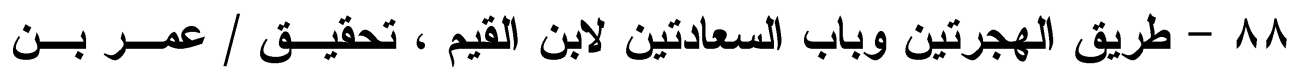

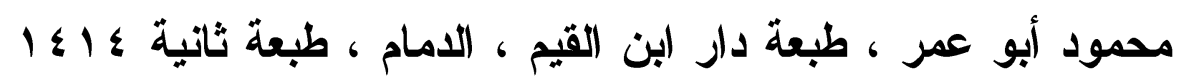

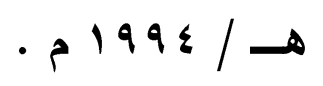

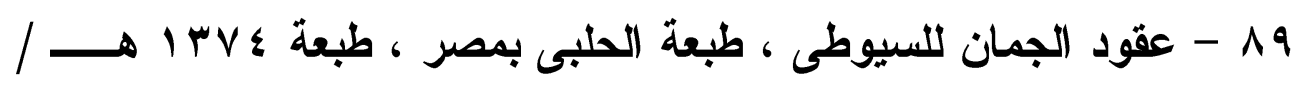

$$
\text { - 1900 }
$$

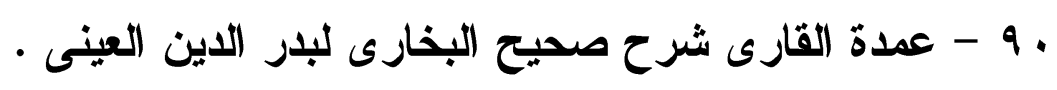

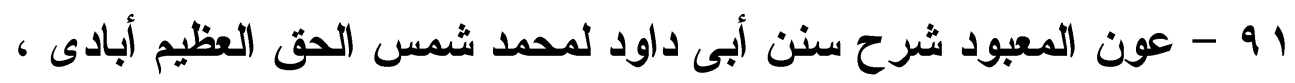

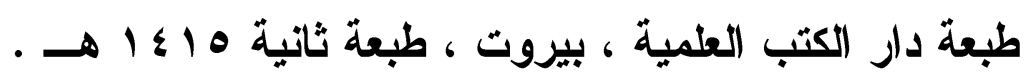

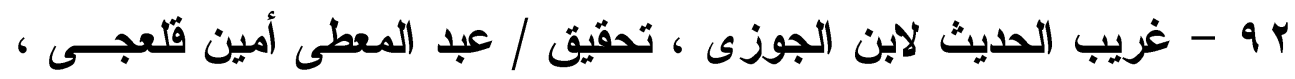

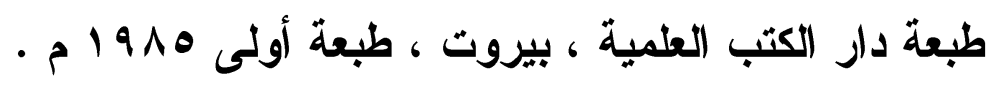

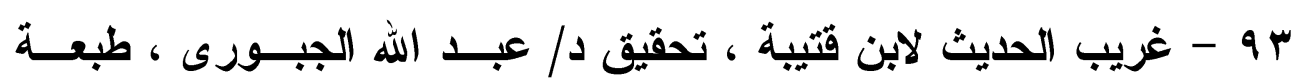

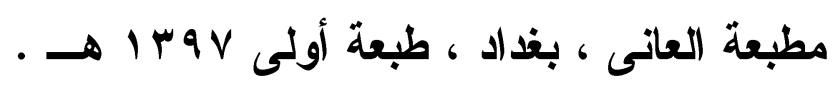

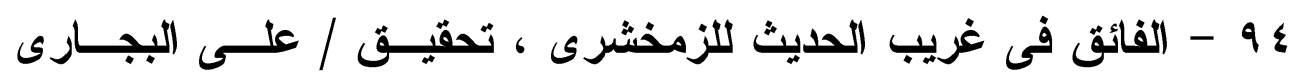

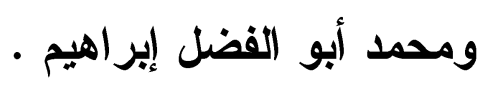

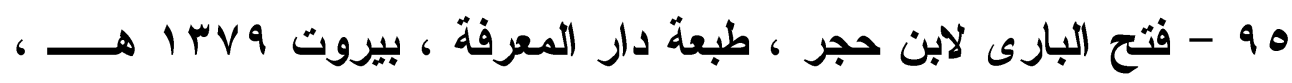

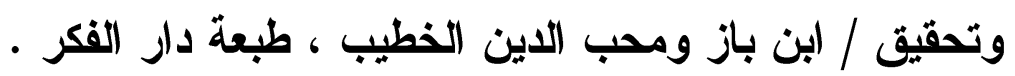

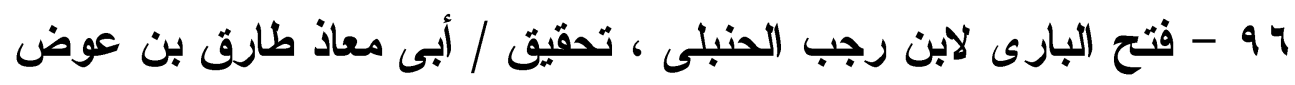

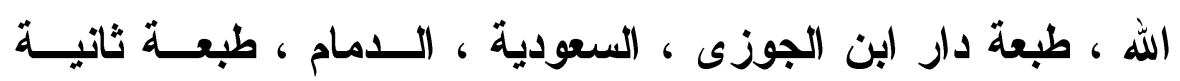

$$
\text { - }
$$

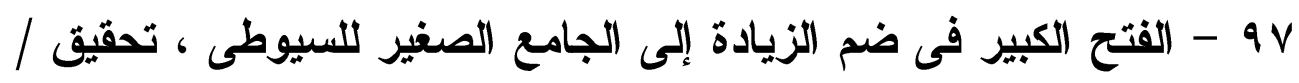

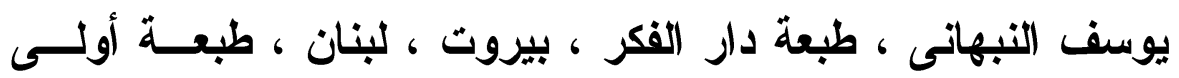

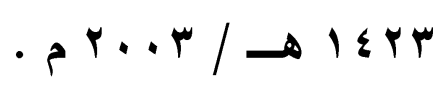

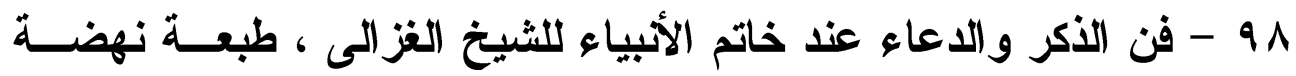


مصر ، طبعة أولى . مأل

99 - الفوائد لابن القيم ، طبعة دار الكتب العلمية ، بيروت ، طبعة ثانيـة

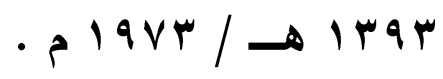

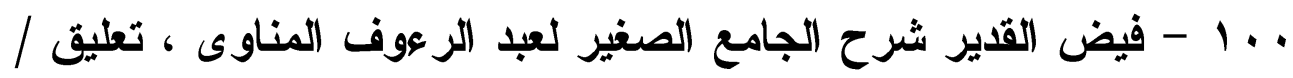

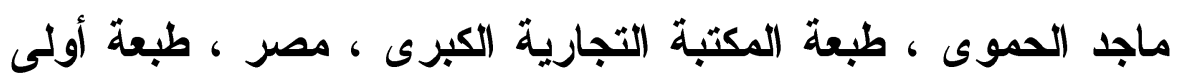

$$
\text { - } 1 \text { 1 } 107
$$

1 . 1 - القاموس الفقهى لغة واصطلاحاً سعد أبو حبيب ، طبعة دار الفكر ،

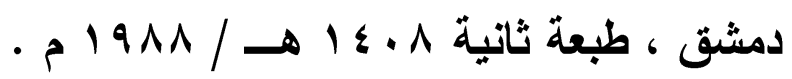

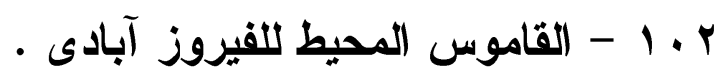
r • 1 - الكامل فى اللغة والأدب للمبرد ، تحقيق / محمد أبو الفضل إير اهيم

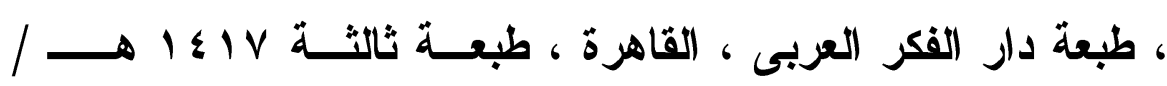

$$
\text { - } 199 \mathrm{~V}
$$

ع . 1 - الكتاب لسيبويه ، تحقيق عبد السلام هارون ، طبعة دار الجيـل ،

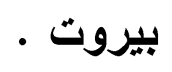

ه. 1 - كتاب الأصول فى النحو لابن السراج ، تحقبــ / عبـــ المحسـن

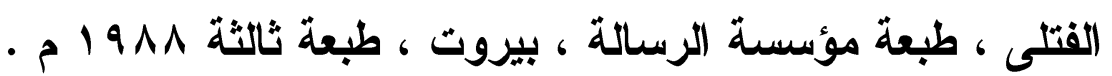
7 . 1 - كتاب الجمل فى النحو للخليل بن أحمد ، تحقيق د/ فخر الاين قباوة

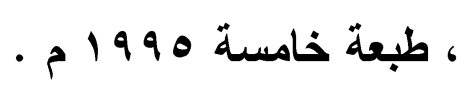

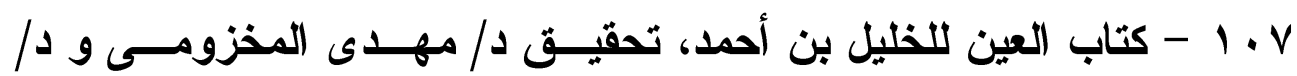
إبر اهيم السامر ائح ، طبعة دار ومكتبة المهله .

1 . 1 - كتاب الكليات لأبى البقاء الكفومى ، تحقيق / عدنان درويش ومحمد

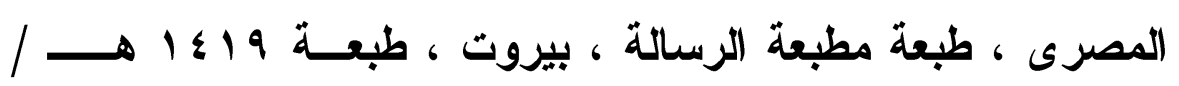


9 . 1 - كتاب اللمع فى العربية لابن جنى ، تحقيق / فائز فارس ، طبعة دار

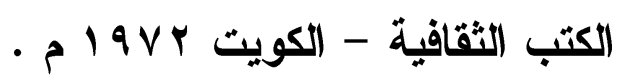

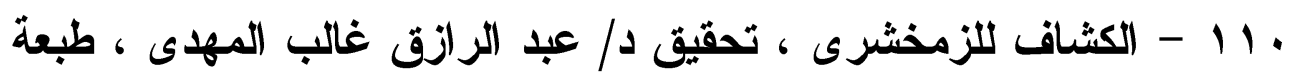

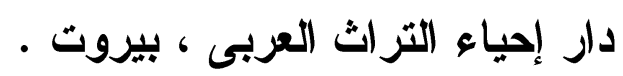

111

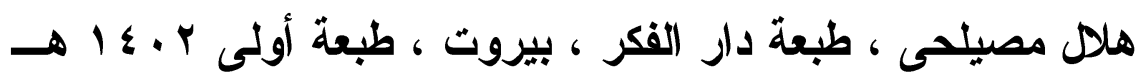

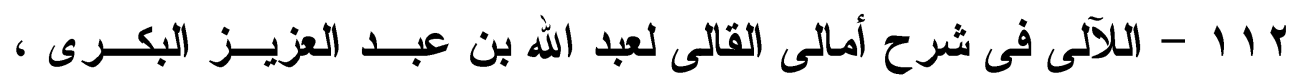

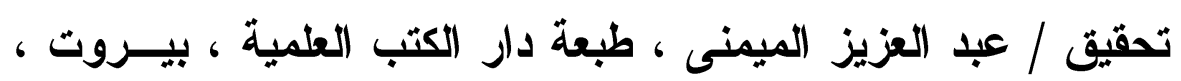

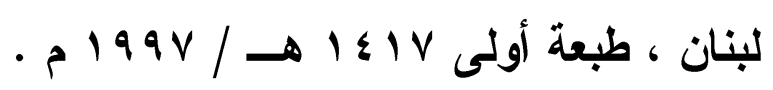

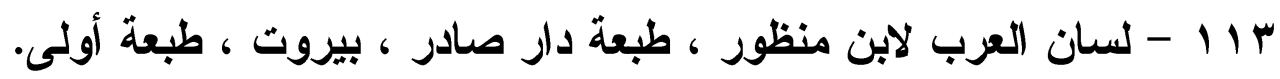

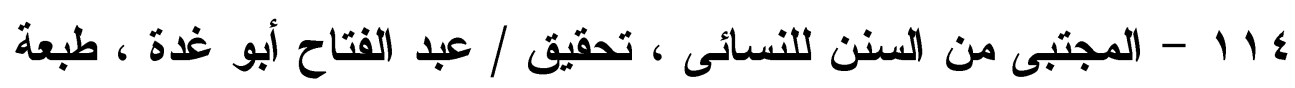

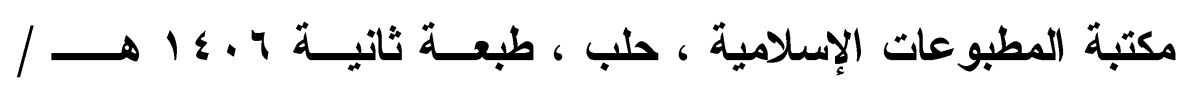

$$
\text { - 1919 }
$$

110

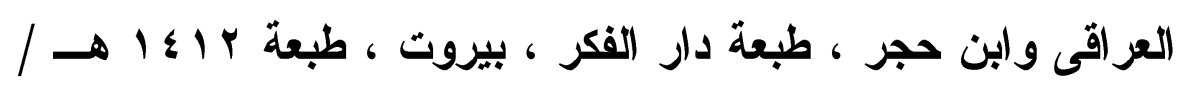

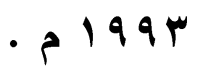

$$
\begin{aligned}
& \text { 111 } 117
\end{aligned}
$$

IIV

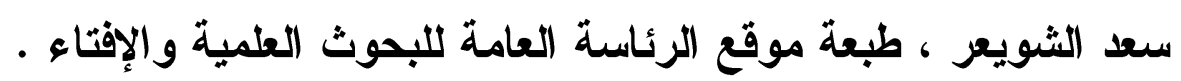

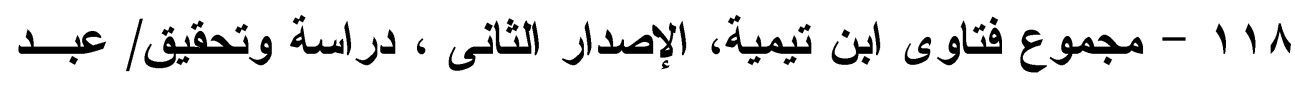

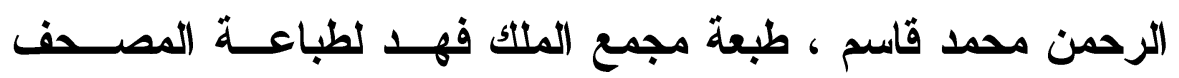

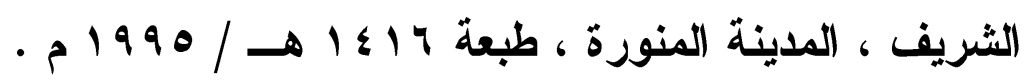
119 


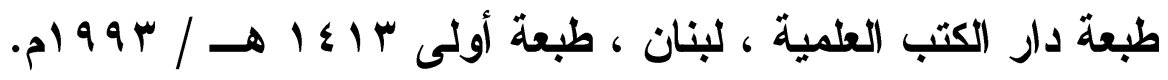

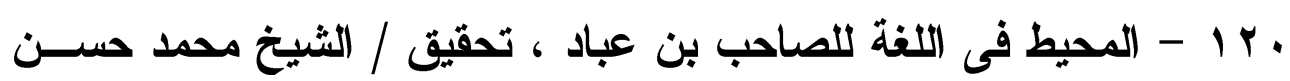

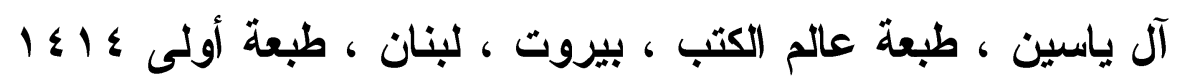

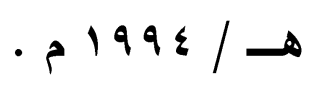

I I I - مختصر السعد التقتازانى ، طبعة دار الكتب العلمية ، بيروت .

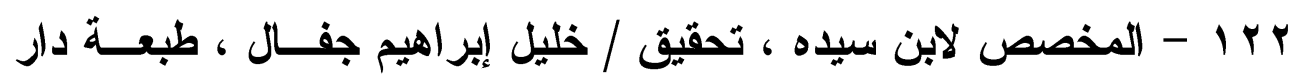

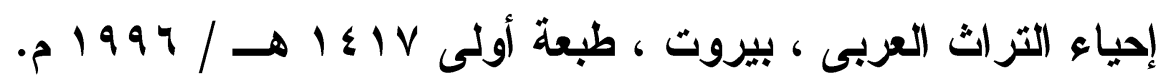

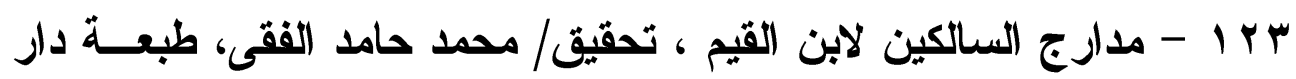

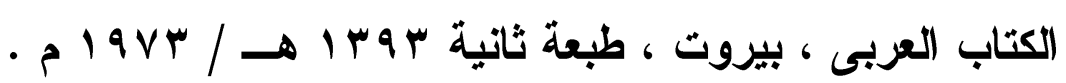

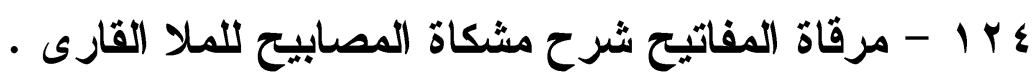

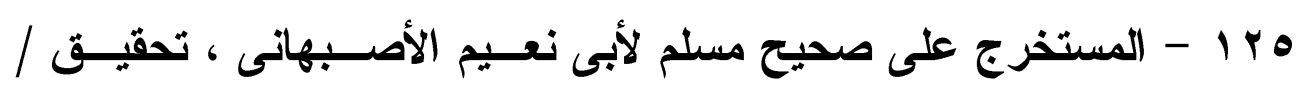

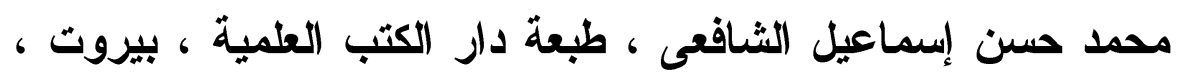

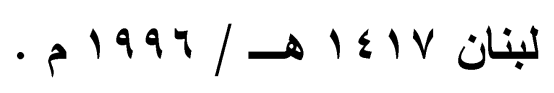

צr 1 - المستدرك للحاكم ، تحقيق / مصطقى عبد القادر عطا ، طبعـة دار

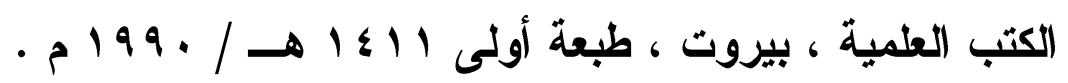

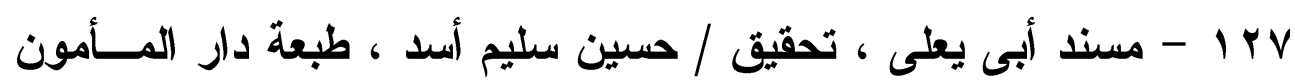

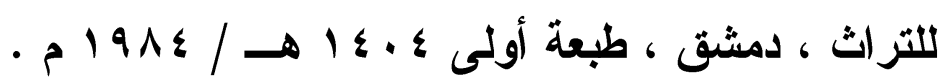

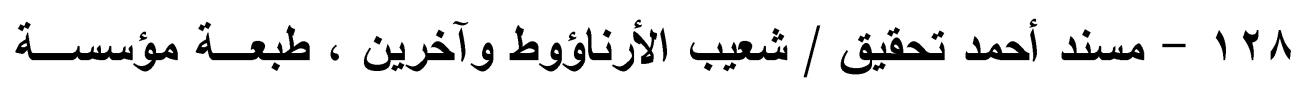

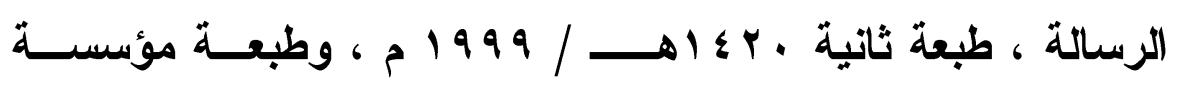

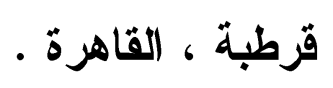

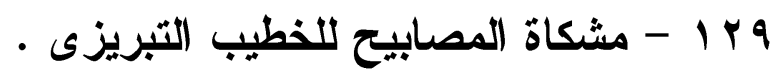
. Iا - مصابيح التنوير على صحيح الجامع الصغير للألبانى .

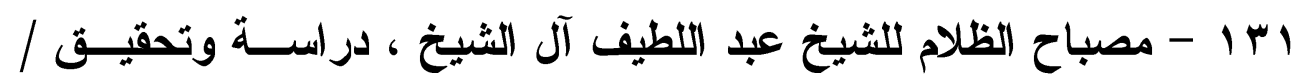


الثيخ عبد العزيز بن عبد الله الزير آل أحمد ، طبعة وزارة الثئون

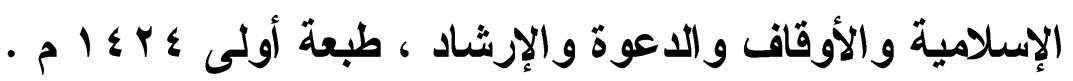

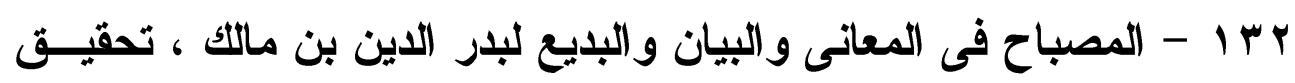
د/ حسنى عبد الجليل يوسف ، طبعة مكتبة الآداب بالجماميز ، بلدون.

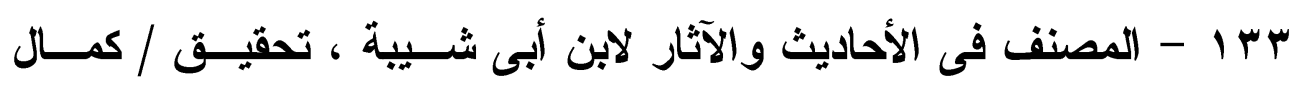

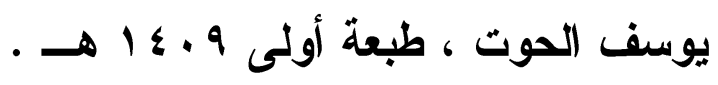

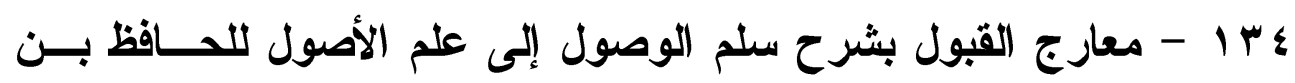

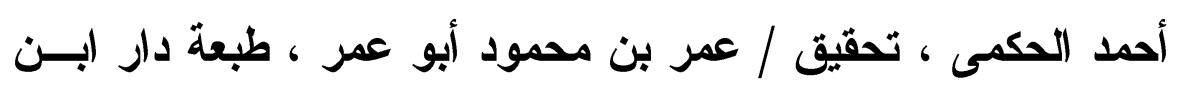

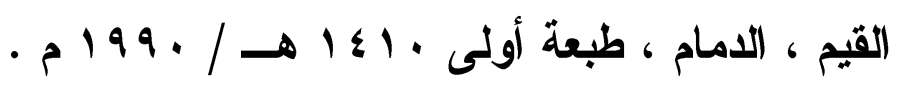

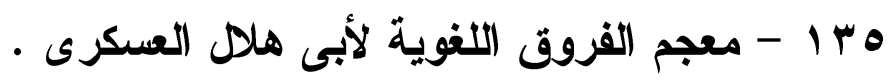

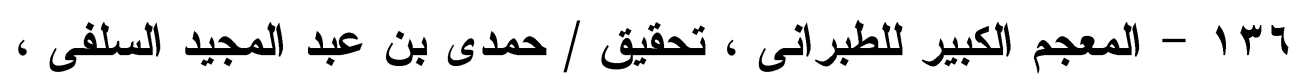

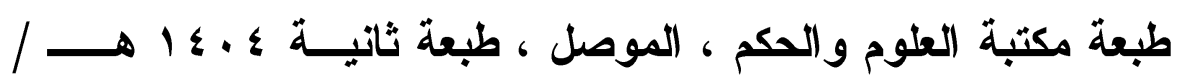

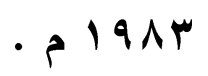

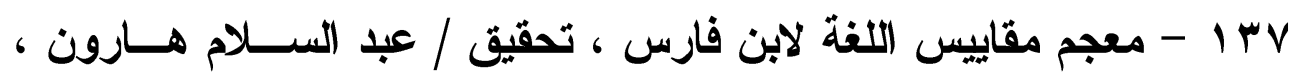

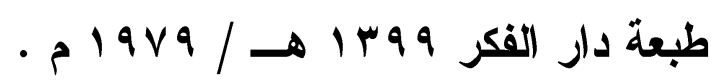

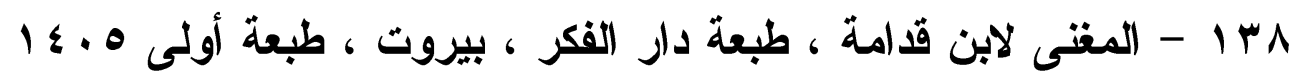
9 ب ا - المفردات فى غريب ألفاظ القرآن للراغب الأصفهانى ، طبعـة دار

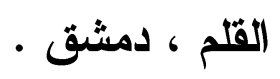
• ع ا - المفهم لما أثنكل من تلخيص مسلم لأبى العباس القرطبى .

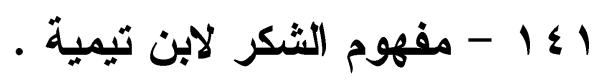

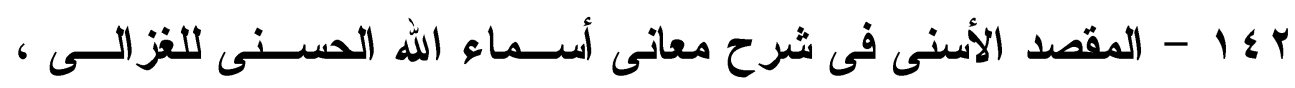

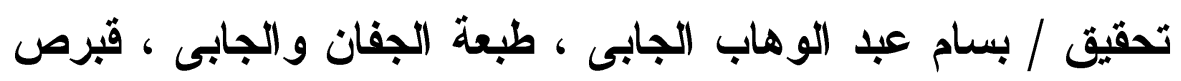




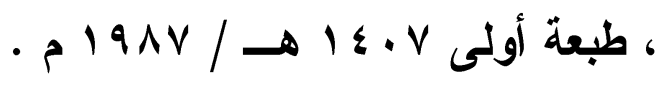

بـ 1 - المنهاج شرح صحيح مسلم بن الحجاج للنووى ، طبعة دار إحيـاء

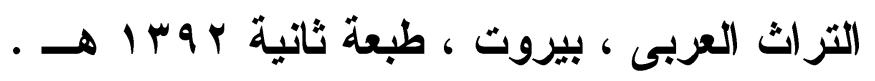

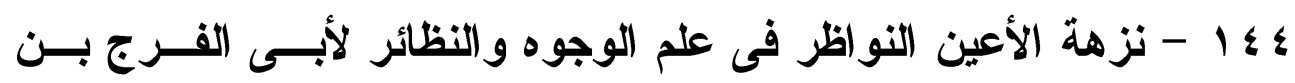
الجوزى ، تحقيق / محمد عبد الكريم كاظم الراضى ، طبعة مؤسسة

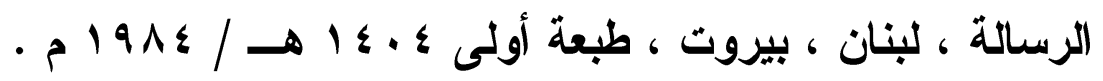

ه ؛ 1 - نظم الارر للبقاعى، تحقيق/ عبد الرازق غالب المهدى ، طبعة دار

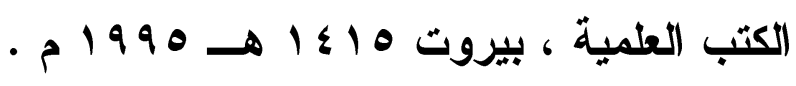

\ 1 - نهاية الزين فى إرشاد المبتدئين لمحمد بن عمر الجاوى ، طبعة دار

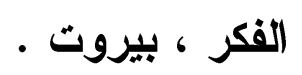

\&V V الزاوى ومحمود محمد الطناحى ، طبعة المكتبة العلميــة ، بيــروت

$$
\text { - } 19 \vee 9 / \rightarrow 9 q
$$

^ء 1 - نيل الأوطار للشوكانى ، طبعة إدارة الطباعة المنيرية . 